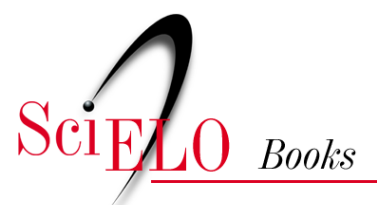

\title{
Entre Demografia e Antropologia povos indígenas no Brasil
}

\author{
Ricardo Ventura Santos \\ Bruno Nogueira Guimarães \\ Marden Barbosa de Campos \\ Marta Maria do Amaral Azevedo \\ (orgs.)
}

SANTOS, R.V., GUIMARÃES, B.N., CAMPOS, M.B., and AZEVEDO, M.M.A., comps. Entre Demografia e Antropologia: povos indígenas no Brasil [online]. Rio de Janeiro: Editora FIOCRUZ, 2019, 264 p. Saúde dos povos Indígenas collection. ISBN: 978-65-5708-013-9. https://doi.org/10.7476/9786557080139. \section{International license.}

All the contents of this work, except where otherwise noted, is licensed under a Creative Commons Attribution 4.0

Todo o conteúdo deste trabalho, exceto quando houver ressalva, é publicado sob a licença Creative Commons Atribição 4.0. 
Entre Demografia e Antropologia: povos indígenas no Brasil 


\title{
FUNDAÇÃO OSWALDO CRUZ \\ Presidente \\ Nísia Trindade Lima
}

Vice-Presidente de Educação, Informação e Comunicação Cristiani Vieira Machado

\author{
EDITORA FIOCRUZ \\ Diretora \\ Cristiani Vieira Machado \\ Editor Executivo \\ João Carlos Canossa Mendes \\ Editores Científicos \\ Carlos Machado de Freitas \\ Gilberto Hochman \\ Conselho Editorial \\ Denise Valle \\ José Roberto Lapa e Silva \\ Kenneth Rochel de Camargo Jr. \\ Lígia Maria Vieira da Silva \\ Marcos Cueto \\ Maria Cecília de Souza Minayo \\ Marilia Santini de Oliveira \\ Moisés Goldbaum \\ Rafael Linden \\ Ricardo Ventura Santos
}

Coleção Saúde dos Povos Indígenas

Editores Responsáveis: Ricardo Ventura Santos

Carlos E. A. Coimbra Jr. 
Entre Demografia e Antropologia: povos indígenas no Brasil

Ricardo Ventura Santos

Bruno Nogueira Guimarães

Marden Barbosa de Campos

Marta Maria do Amaral Azevedo

organizadores 
Copyright (C) 2019 dos autores

Todos os direitos desta edição reservados à

FUNDAÇÃO OSWALDO CRUZ / EDITORA

A publicação deste volume contou com apoio financeiro do Projeto Saúde dos Povos Indígenas no Brasil: perspectivas históricas, socioculturais e políticas, coordenado por Ricardo Ventura Santos (Wellcome Trust, 203486/Z/16/Z).

Revisão

M. Cecilia Gomes Barbosa Moreira

Normalização de referências

Clarissa Bravo

Capa

Danowski Design

Criada a partir de símbolos gráficos guarani para números.

Fonte: "Etnomatemática do sistema de contagem guarani das aldeias Itaty, do Morro dos Cavalos, e M'Biguaçu", de Sérgio Florentino da Silva e Ademir Donizeti Caldeira. Bolema: Boletim de Educação Matemática, 30(56): 992-1.013, 2016.

Projeto gráfico

Angélica Mello

Daniel Pose

Editoração

Robson Lima (Obra Completa Comunicação)

Produção editorial

Phelipe Gasiglia

Catalogação na fonte

Fundação Oswaldo Cruz

Instituto de Comunicação e Informação Científica e Tecnológica em Saúde Biblioteca de Saúde Pública

E61e

Entre Demografia e Antropologia: povos indígenas no Brasil / organizado por Ricardo Ventura Santos et al. - Rio de Janeiro : Editora Fiocruz, 2019.

264 p. : il. ; tab. (Coleção Saúde dos Povos Indígenas)

ISBN: 978-85-7541-636-5

1. Índios Sul-Americanos. 2. Demografia. 3. Antropologia. 4. Migração Humana. 5. Política Pública. 6. Renda. 7. Dados Censitários. 8. Parto. 9. Epidemias. 10. Brasil. I. Santos, Ricardo Ventura (Org.). II. Guimarães, Bruno Nogueira (Org.). III. Campos, Marden Barbosa (Org.). IV. Azevedo, Marta Maria Amaral (Org.). V. Título.

CDD - 23.ed. - 980.410981

2019

EDITORA FIOCRUZ

Av. Brasil, 4036, térreo, sala 112 - Manguinhos

21040-361 - Rio de Janeiro, RJ

Editora filiada

Tels.: (21) 3882-9039 e 3882-9041

Telefax: (21) 3882-9006

editora@fiocruz.br

www.fiocruz.br

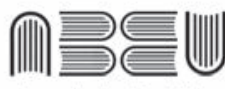


Dedicamos este livro à memória da colega Heloisa Pagliaro, uma pessoa amiga, agregadora e profissional da mais elevada competência. Seus estudos pioneiros sobre a demografia dos povos indígenas foram fundamentais para a consolidação deste campo de investigação no país 
Alessandra Traldi Simoni é cientista social, doutoranda em demografia no Programa de Pós-Graduação em Demografia da Universidade Estadual de Campinas.

Barbara Coelho Barbosa da Cunha é bióloga, doutora em epidemiologia pelo Programa de Pós-Graduação em Saúde Pública da Escola Nacional de Saúde Pública Sergio Arouca da Fundação Oswaldo Cruz.

Bruna Barradas Cordeiro é cientista social, mestranda no Programa de Pós-Graduação em Sociologia da Universidade Federal de Minas Gerais.

Bruno Nogueira Guimarães (organizador) é cientista social, doutor em antropologia social pelo Programa de Pós-Graduação em Antropologia Social do Museu Nacional da Universidade Federal do Rio de Janeiro e pós-doutorando no Programa de Pós-Graduação em Epidemiologia em Saúde Pública da Escola Nacional de Saúde Pública Sergio Arouca da Fundação Oswaldo Cruz.

Carolina Arouca Gomes de Brito é historiadora, doutora em História das Ciências e da Saúde pelo Programa de Pós-Graduação em História das Ciências e da Saúde da Casa de Oswaldo Cruz da Fundação Oswaldo Cruz e pós-doutoranda no Programa de Pós-Graduação em Políticas Sociais da Universidade Estadual do Norte Fluminense.

Diego Rodrigues Macedo é geógrafo, doutor em ecologia pelo Programa de Pós-Graduação em Ecologia da Universidade Federal de Minas Gerais (UFMG). É professor do Departamento de Geografia da UFMG.

Elizabeth Pissolato é graduada em história, doutora em antropologia social pelo Programa de Pós-Graduação em Antropologia Social do Museu Nacional da Universidade Federal do Rio de Janeiro. É professora do Departamento de Ciências Sociais e do programa de Pós-Graduação em Ciências Sociais da Universidade Federal de Juiz de Fora. 
Evelyne Marie Therese Mainbourg é graduada em enfermagem e em desenvolvimento econômico e social, doutora em sociologia pela Université de Tours (França). É pesquisadora do Instituto Leônidas G Maria Deane da Fundação Oswaldo Cruz de Manaus.

Geraldo Marcelo Cunha é matemático, doutor em estatística pelo Programa de Pós-Graduação em Estatística da Universidade Federal do Rio de Janeiro. É pesquisador da Escola Nacional de Saúde Pública Sergio Arouca da Fundação Oswaldo Cruz.

Gerson Luiz Marinho é graduado em enfermagem, doutor em epidemiologia pelo Programa de Pós-Graduação em Epidemiologia em Saúde Pública da Escola Nacional de Saúde Pública Sergio Arouca da Fundação Oswaldo Cruz. É professor da Escola de Enfermagem Anna Nery da Universidade Federal do Rio de Janeiro.

Ítalo Ottoni de Matos é graduando em ciências sociais da Universidade Federal de Minas Gerais.

João Luiz Bastos é graduado em odontologia, doutor em epidemiologia pelo Programa de Pós-Graduação de Epidemiologia da Universidade Federal de Pelotas. É professor do Departamento de Saúde Pública da Universidade Federal de Santa Catarina.

João Pacheco de Oliveira é antropólogo, doutor em antropologia social pelo Programa de Pós-Graduação em Antropologia Social do Museu Nacional da Universidade Federal do Rio de Janeiro (UFRJ). É professor do Departamento de Antropologia do Museu Nacional da UFRJ.

Luciene Aparecida Ferreira de Barros Longo é economista, doutora em demografia pelo Programa de Demografia do Centro de Desenvolvimento e Planejamento Regional da Universidade Federal de Minas Gerais. É tecnologista em informações geográficas e estatísticas do Instituto Brasileiro de Geografia e Estatística.

Luciene Guimarães de Souza é cientista social, doutora em saúde pública pelo Programa de Saúde Pública da Escola Nacional de Saúde Pública Sergio Arouca da Fundação Oswaldo Cruz. 
Ludimila Raupp é bióloga, doutora em epidemiologia em saúde pública pelo Programa de Pós-Graduação em Epidemiologia em Saúde Pública da Escola Nacional de Saúde Pública Sergio Arouca da Fundação Oswaldo Cruz. É professora do Departamento de Biologia da Pontifícia Universidade Católica do Rio de Janeiro.

Marden Barbosa de Campos (organizador) é economista, doutor em demografia pelo Programa de Pós-Graduação em Demografia do Centro de Desenvolvimento e Planejamento Regional da Universidade Federal de Minas Gerais (UFMG). É professor do Departamento de Sociologia da UFMG.

Marília Brasil é economista, mestre em demografia pelo Programa de Pós-Graduação em Demografia do Centro de Desenvolvimento e Planejamento Regional da Universidade Federal de Minas Gerais. É professora da Universidade Federal do Amazonas.

Marta Antunes é economista, doutora em antropologia social pelo Programa de Pós-Graduação em Antropologia Social da Universidade Federal do Rio de Janeiro. É tecnologista em informações geográficas e estatísticas do Instituto Brasileiro de Geografia e Estatística.

Marta Maria do Amaral Azevedo (organizadora) é antropóloga, doutora em demografia pelo Programa de Pós-Graduação em Demografia da Universidade Estadual de Campinas (Unicamp). É pesquisadora do Núcleo de Estudos de População Elza Berquó e professora do Programa de Pós-Graduação em Demografia da Unicamp.

Nancy May Flowers é antropóloga, doutora pelo Departamento de Antropologia da City University of New York.

Nilza de Oliveira Martins Pereira é estatística, doutora em saúde pública pelo Programa de Saúde Pública da Escola Nacional de Saúde Pública Sergio Arouca da Fundação Oswaldo Cruz.

Oswaldo Gonçalves Cruz é biólogo, doutor em engenharia biomédica pelo Programa de Engenharia Biomédica do Instituto Alberto Luiz Coimbra de PósGraduação e Pesquisa de Engenharia da Universidade Federal do Rio de Janeiro. É pesquisador do Programa de Computação Científica da Fundação Oswaldo Cruz.

Pery Teixeira é matemático, doutor em demografia pelo Programa de Demografia do Centro de Desenvolvimento e Planejamento Regional da Universidade Federal de Minas Gerais. 
Ricardo Ventura Santos (organizador) é graduado em ciências biológicas, doutor em antropologia pelo Departamento de Antropologia da Indiana University (Estados Unidos). É pesquisador da Escola Nacional de Saúde Pública Sergio Arouca da Fundação Oswaldo Cruz e professor do Departamento de Antropologia do Museu Nacional da Universidade Federal do Rio de Janeiro.

Ricardo Verdum é cientista social, doutor em antropologia social da América Latina e Caribe pelo Centro de Pesquisa e Pós-Graduação sobre as Américas da Universidade de Brasília.

Rosa Sebastiana Colman é geógrafa, doutora em demografia pelo Programa de Pós-Graduação em Demografia da Universidade Estadual de Campinas. É professora da Faculdade Intercultural Indígena da Universidade Federal da Grande Dourados.

Thatiana Fávaro é nutricionista, doutora em saúde pública pelo Programa de Pós-Graduação em Epidemiologia em Saúde Pública da Escola Nacional de Saúde Pública Sergio Arouca da Fundação Oswaldo Cruz. É professora da Faculdade de Nutrição da Universidade Federal de Alagoas. 
Sumário

Apresentação

Parte I - Perspectivas a partir do Campo

1. O Censo Visto da Aldeia: lendo dados demográficos com base na etnografia Apanjekra.....

Bruno Nogueira Guimarães

2. Dinâmica Territorial e Mobilidade Espacial entre os Kaiowá e Guarani no Mato Grosso do Sul 55

Rosa Sebastiana Colman e Marta Maria do Amaral Azevedo

3. Migração do Povo Indígena Sateré-Mawé em Dois Contextos Urbanos na Amazônia .75

Pery Teixeira, Evelyne Marie Therese Mainbourg e Marília Brasil

4. A Política de Transferência de Renda Condicionada e os Povos Indígenas no Brasil

Ricardo Verdum

Parte II - Dados Censitários em Contexto

5. Indígenas em Belo Horizonte: o uso dos dados de setores censitários para estudos intraurbanos

Marden Barbosa de Campos, Bruna Barradas Cordeiro, Ítalo Ottoni de Matos e Diego Rodrigues Macedo

6. Declaração de Idade em Indígenas e Não Indígenas no

Censo Demográfico de 2010 139

Barbara Coelho Barbosa da Cunha, Thatiana Fávaro, Luciene Guimarães de Souza, Ludimila Raupp, Geraldo Marcelo Cunha e Ricardo Ventura Santos 
7. Parturição em Mulheres Indígenas e Não Indígenas do Brasil:

o número de filhos relatados depende de quem responde às perguntas do censo nacional?

Ricardo Ventura Santos, João Luiz Bastos, Oswaldo Gonçalves Cruz,

Luciene Aparecida Ferreira de Barros Longo, Nancy May Flowers e Nilza de Oliveira Martins Pereira

8. "Você Se Considera Indígena?": características da população residente em terras indígenas investigadas pelo Censo Demográfico de 2010

Gerson Luiz Marinho, Ricardo Ventura Santos e Alessandra Traldi Simoni

Parte III - Trajetórias, Categorias, Implicações

9. "Convívio e Contaminação": uma análise sócio-histórica sobre

epidemias, demografia e povos indígenas na obra de Darcy Ribeiro 203

Carolina Arouca Gomes de Brito

10. Indígenas e Pesquisa Demográfica: sugestões ao debate sobre religião e indígenas no contexto do censo brasileiro

Elizabeth Pissolato

11. Os Indígenas nos Censos Demográficos: entrevista com João Pacheco de Oliveira

João Pacheco de Oliveira e Marta Antunes

12. Memórias Acadêmico-Afetivas sobre a Demografia dos Povos Indígenas no Brasil: entrevista com Marta Maria do Amaral Azevedo 241

Marta Maria do Amaral Azevedo, Alessandra Traldi Simoni,

Bruno Nogueira Guimarães e Ricardo Ventura Santos 


\section{Apresentação}

Há quase quatro décadas atrás, em 1982, realizou-se uma sessão sobre demografia dos povos indígenas no $3^{\circ}$ Encontro Nacional da Associação Brasileira de Estudos Populacionais (Abep), em Vitória (ES). Foi nesse evento, organizado pela antropóloga Lux Vidal, da Universidade de São Paulo, que, pela primeira vez, se debateu o tema da demografia indígena de maneira explícita e ampla em um evento da Abep, a principal associação acadêmica que congrega interessados no estudo de populações no Brasil.

Intitulada "Demografia dos grupos étnicos minoritários: índios", a sessão contou com quatro apresentadores: o antropólogo Leonardo Fígoli, da Universidade de Brasília, com o trabalho "Migração indígena a Manaus"; o antropólogo Jorge Oswaldo Romano, com a comunicação "Etnicidad y proletarizacion"; o geneticista Francisco M. Salzano, da Universidade Federal do Rio Grande do Sul, com o texto "Fertilidade, mortalidade, migração e miscigenação em 14 tribos indígenas da América do Sul", e a própria Vidal, cuja contribuição teve o mesmo título da sessão. Em sua apresentação, Vidal justificou a organização da sessão:

Estudar a evolução demográfica dos índios brasileiros esbarra imediatamente com várias dificuldades, a da precariedade e irregularidade dos censos, a falta absoluta de estatísticas vitais contínuas e geralmente, o pouco interesse científico manifestado com relação aos dados demográficos como capazes de auxiliar a compreensão de outros aspectos, como a organização política, a adaptação ao meio ambiente, as migrações e guerras, a visão do mundo, assim como as reações ao processo aculturativo.

A reconstituição da história demográfica de cada grupo específico é extremamente difícil e desigual no seu valor, onde foi realizada, e na maioria dos casos é inexistente. (Vidal, 1982a: 405)

O texto de Vidal traz comentários acerca de fontes com potencial para estudos em demografia histórica sobre a população indígena (com ênfase nos escritos de cronistas e missionários), da inexistência de trabalhos sistemáticos sobre a 
demografia dos povos indígenas por agências governamentais ("o recenseamento feito pelo Governo (...) não segue nenhum critério específico no que diz respeito à situação real desses povos (...) excluindo (...) toda ou qualquer pergunta que venha a documentar a situação histórica atual desses povos") e da fragilidade dos dados ("esparsos ou sigilosos") da Fundação Nacional do Índio (Funai) ("órgão tutelar [que] nunca se interessa num levantamento sistemático do material que possui em suas delegacias" (Vidal, 1982a: 406-407). Apesar das inúmeras dificuldades, a antropóloga também faz alusão ao fato de que, naquele momento, início dos anos 1980, alguns levantamentos sobre o tamanho das populações indígenas eram realizados por organizações não governamentais - como o Conselho Indigenista Missionário (Cimi) e o Centro Ecumênico de Documentação e Informação (Cedi).

O cerne da comunicação de Vidal estava no detalhamento de dados demográficos de um "certo número de casos concretos", incluindo os Xokleng (SC), Bororo (MT), Xavante (MT), Tapirapé (GO), Xikrin (PA) e Pataxó (BA), "tratando de cada caso à luz de uma série de variáveis que definem situações bastante diferentes, mas também revelam tendências mais gerais" (Vidal, 1982a: 407).

O breve texto da antropóloga ${ }^{1}$ termina com o que, a partir de uma leitura dos dias de hoje, em 2019, se configura como um amplo e ambicioso plano de pesquisa: "o nosso objetivo seria uma proposta para um projeto de estudos sobre demografia indígena e que poderia eventualmente levar a uma proposta de reformulação dos questionários e tratamento do Censo oficial" (Vidal, 1982a: 407).

No encontro seguinte da Abep, realizado em São Pedro (SP), em 1984, o tema da demografia dos povos indígenas foi novamente abordado, dessa vez em uma sessão intitulada "Etnia e população", organizada pela demógrafa Laura Wong, à época vinculada à Fundação Sistema Estadual de Análise de Dados (Fundação Seade), em São Paulo. Os participantes incluíram, novamente, Salzano, com o trabalho "Migrações, etnia e casamento entre indígenas sul-americanos"; a antropóloga Carmen Junqueira, da Pontifícia Universidade Católica de São Paulo (PUC-SP), com a contribuição "Alguns dados sobre a população Cinta-Larga"; o demógrafo Túlio Penna, da Secretaria de Saúde do Estado de São Paulo e da Comissão Pró-Índio, com o texto "Por que demografia indígena brasileira?"; e a própria Laura Wong, que, em parceria com Penna, apresentou o trabalho "Perfil demográfico da população indígena no Estado de São Paulo: uma proposta de estudo".

Nota-se que, em comparação com a sessão de 1982, a de 1984 apresenta, talvez já em resposta à sugestão de Vidal, propostas concretas voltadas para a captação de dados demográficos acerca das populações indígenas. É o caso de Penna, cujo trabalho, centrado em uma discussão de dados demográficos sobre os Xavante (Mato Grosso), recomenda, no anexo, censos indígenas regulares e um sistema de coleta e análise de dados demográficos. Essa proposta se apoia em três pilares: 1) realização de censos quinquenais pela Funai e missões religiosas; 2) implantação de um sistema de relatórios periódicos e padronizados com estatísticas vitais; 
3) criação de um setor de demografia na Funai, "que reunisse, processasse e analisasse os dados, possibilitando ter-se sempre em dia, o perfil demográfico das populações indígenas brasileiras" (Penna, 1984: 1582). Na visão do autor, seria uma proposta a ser realizada em uma parceria da Funai com organizações como o Cimi, a Abep, o Instituto Brasileiro de Geografia e Estatística (IBGE), o Cedi e a Associação Brasileira de Antropologia (ABA).

Há dois outros aspectos que se destacam no registro da sessão nos anais do congresso da Abep de 1984. O primeiro é a referência ao contexto institucional da associação, no tocante à temática indígena, que teria influenciado a realização de sessões sobre a questão em dois eventos consecutivos:

A Presidente da Abep, dra. Elza Berquó, achou conveniente lembrar que a sessão nasceu como inquietude de um grupo de associados - entre os quais se pode citar o nome de Lux Vidal - com a finalidade de chamar a atenção sobre a problemática indígena e cobrar dos estudiosos de população a devida atenção para os grupos étnicos minoritários, entre eles, os índios. (Wong, 1984: 1.561)

O segundo está relacionado à manifestação de Marcos Terena, uma importante e emergente liderança indígena. Naquele período, ele participava, juntamente com outros jovens indígenas, de uma das primeiras organizações, a União das Nações Indígenas (UNI), que viria a ter um destacado papel nos rumos do movimento indígena no Brasil (Ramos, 1998; Barbosa G Fagundes, 2018). Nascido no que é hoje Mato Grosso do Sul e estudante em Brasília nos anos 1970, Terena chamou atenção na sessão da Abep de 1984 para a questão da presença indígena nas cidades:

O índio Marcos Terena pede que a Abep continue voltando seu pensamento para as comunidades indígenas. Os índios querem saber como se está expandindo a população, pois a juízo próprio é preciso conhecer e documentar alguns desequilíbrios. (...) [Os índios] abstêm-se de identificar-se como índios para evitar problemas com a Funai, com a própria aldeia e até com os próprios empregadores. Escondem-se na cidade, perdem-se na civilização, negam sua origem sem ter condições de voltar. Espera da Abep que procure analisar estas situações, ou seja, identificar o índio da cidade, os que saem da aldeia, os que saem das cidades para outras mais distantes, e qual o destino deles. (Wong, 1984: 1.562)

Essas duas sessões da Abep, realizadas nos anos 1980, foram de vital importância para a constituição do campo dos estudos sobre demografia dos povos indígenas no âmbito da organização e no país (Pagliaro, Azevedo G Santos, 2005).2 Chama a atenção o fato de que foram estruturadas com base em uma miscelânea de temas e perspectivas caras a diferentes atores sociais. Antropólogos, geneticistas, demógrafos e os próprios indígenas discutiam migração, proletarização, urbanização, matrimônio e etnia. Levantavam questões sobre a falta de dados, faziam propostas de levantamentos populacionais e alusão aos recenseamentos nacionais. Tudo isso 
envolto na complexa dinâmica dos processos identitários, o "negar as origens", o "se perder na civilização" e o problema da visibilidade nos diferentes contextos em que a indianidade poderia se manifestar.

O Brasil do início da década de 1980 atravessava os anos finais da ditadura militar, que se alongou de 1964 a 1985. A perspectiva desenvolvimentista que marcou o período, incluindo os planos de construção de rodovias e de hidrelétricas e o estímulo a projetos de mineração, impactou fortemente populações indígenas das mais diversas regiões do país, e da Amazônia em particular, vindo associada a epidemias, desestruturação social e realocações forçadas, entre outras consequências nefastas (Davis, 1978; Martins, 1982; Ribeiro, 1977; Valente, 2017). As duas sessões da Abep mencionadas realizaram-se em um período em que se intensificavam os debates sobre a redemocratização no país. No tocante aos povos indígenas, a tônica desses novos ares se fez refletida no texto introdutório da publicação Povos Indígenas no Brasil 1980, da série Aconteceu, do Cedi:

Se por um lado surgiu e tomou corpo a consciência indígena a nível nacional e as organizações e apoio brancas passaram a uma atuação solidária com os destinos do índio, por outro lado, organizaram-se e articularam-se os interesses anti-índios (...). Se muitos povos indígenas só agora começam a procurar caminhos para a autodeterminação (...), muitos deles ainda sofrem o impacto do contato (...). Ao contrário do que muita gente pensa, e deseja, os índios não vão desaparecer. (...) E mais: a população desses grupos está aumentando. Não vão desaparecer e não vão deixar de ser índios. (Cedi, 1981: 1)

Como se depreende do trecho citado, no contexto político da virada dos anos 1970 para os 1980, questões acerca da demografia dos povos indígenas desaparecimento versus permanência e crescimento - eram centrais nas discussões sobre seus direitos. A contagem da população indígena e a constatação de que estavam crescendo estavam longe de serem meros exercícios técnico-científicos. Eram também meios para se pensar as possibilidades sobre o futuro destes povos.

Nesse período, os esforços para traçar o perfil populacional dos indígenas no Brasil partiram da sociedade civil. No final da década de 1970 e no início da seguinte, colaboradores e integrantes do Cimi - padres, freiras e antropólogos contabilizaram a população indígena das aldeias conhecidas, percorrendo os mais recônditos espaços do país na empreitada. Os números embasaram o "Dossiê sobre a situação dos povos indígenas em todo o Brasil, com levantamento demográfico atualizado - 210.000 índios", primeira publicação a dar conta de uma quantificação, em nível nacional, dos indígenas no período militar (Cimi, 1979). ${ }^{3}$

Na mesma época, o Cedi, que em meados da década de 1990 passaria por uma refundação, tornando-se Instituto Socioambiental (ISA), também lançou uma iniciativa visando à contagem populacional dos indígenas no país. ${ }^{4}$ Para esse fim, 
diversos profissionais se organizaram em uma rede colaborativa com o objetivo de preencher fichas que incluíam dados demográfico acerca dos povos junto aos quais atuavam e a situação da relação destes com o Estado. O esforço coletivo, levado a cabo por antropólogos, profissionais da saúde, professores e outros colaboradores, resultou em mais de 150 fichas entregues ao Cedi no final da década de 1970 e início da de 1980. Esse material serviu de base para a série especial do periódico Aconteceu, que posteriormente se transformaria na publicação Povos Indígenas no Brasil. Do volume sobre o ano 1980 (Cedi, 1981) ao referente aos anos 2011 a 2016 (Ricardo G Ricardo, 2017), a série compreende quase quatro décadas buscando retratar a população indígena.

Os levantamentos realizados pelo Cimi e pelo Cedi, em várias ocasiões apresentados na forma de mapas pontuados pela presença indígena nas mais diversas regiões do Brasil, tiveram importante influência nos debates acerca dos direitos dos povos indígenas na Assembleia Constituinte, que, em 1988, promulgaria a nova Constituição Federal (Azevedo et al., cap. 12 desta coletânea). A "virada demográfica" que estava sendo detectada naquele momento (Gomes, 1988; Pagliaro, Azevedo G Santos, 2005; McSweeney G Alps, 2005) tornou cada vez mais evidente a efetiva possibilidade de permanência dos povos indígenas como segmentos socioculturalmente diferenciados. Esses esforços contribuíram com a articulação política das lideranças indígenas, dos movimentos sociais e dos intelectuais para a aprovação dos artigos 231 e 232 da Constituição Federal de 1988, ampliando os direitos indígenas na garantia do usufruto de suas terras, na defesa de seu modo de vida, bem como sua capacidade de se representar diante do Estado (Carneiro da Cunha, 2009; Cedi 1991; Souza Lima, 1995). Ao "botar os índios no mapa", por meio da caracterização demográfica e da localização geográfica dessas populações, a sociedade civil fortaleceu as bases para a defesa dos direitos dos povos tradicionais.

O que se depreende da trajetória descrita é que as iniciativas de estudo das dinâmicas populacionais indígenas foram (e permanecem) indissociáveis dos contextos históricos e sociopolíticos nos quais se inserem (Axelsson G Sköld, 2011; Campos G Estanislau, 2016; Kertzer G Arel, 2002; Loveman, 2014; Oliveira, 2012). Olhando retrospectivamente, talvez não seja exagero afirmar que o coquetel de elementos que interagiram e se combinaram nas décadas de 1970 e 1980, tendo como pano de fundo o contexto sociopolítico do país, em certa medida transformou em eufemismo a expressão "inquietude de um grupo de associados", como aludiu Berquó. No Brasil da época, o campo da demografia indígena emergiu em meio a acirrados debates sociopolíticos nos anos finais do período da ditadura militar. Demonstrando que "os índios estão no Brasil para ficar", os levantamentos populacionais contribuíram para subverter o paradigma fatalista, que pressupunha um futuro sem indígenas: padeceriam na penúria e na doença ou seriam assimilados 
pela população envolvente, suas diferenças socioculturais dissolvidas na sociedade nacional. O registro de crescimento demográfico oferecia uma alternativa a essa concepção e ao destino dos indígenas, indicando como os fatores de depopulação não eram inevitáveis. A demografia contribuía para consolidar a noção de que o indígena não era um estágio transitório rumo à civilização. Mesmo que, trinta anos após a promulgação da Constituição de 1988, os direitos indígenas ainda estejam distantes de serem plenamente efetivados (Carneiro da Cunha, 2017), os estudos populacionais continuam se mostrando um importante aliado na luta por reconhecimento.

Esta coletânea não foi a princípio organizada, ao menos intencionalmente, tomando como referência esse passado acerca do qual nos referimos anteriormente. Mas, no exercício de se escrever esta Apresentação, as "ligações genealógicas" do presente volume com esse passado se colocaram de forma inequívoca diante de nossos olhos. Desse modo, a coletânea pode ser interpretada como, em larga medida, derivada daquele projeto enunciado em 1982. Quase adentrando na terceira década do século XXI, a publicação do conjunto de textos aqui reunidos permite avaliar como se desdobraram os caminhos da já mencionada proposta de Vidal (1982a) sobre as dinâmicas populacionais indígenas e suas implicações para a produção de estatísticas oficiais. As contribuições coligidas possibilitam observar como os escassos dados demográficos se tornaram bastante mais abundantes e como hoje fomentam políticas públicas. Indicam também como conceitos à época relevantes (tais quais "evolução da população", "adaptação", "aculturação", dentre outros empregados pela própria Vidal) deram lugar a diferentes perspectivas.

Para compreender essas "ligações genealógicas", é preciso levar em consideração a trajetória do Grupo de Trabalho (GT) Demografia dos Povos Indígenas no Brasil da Abep, que foi estabelecido em 2006, mas cuja criação remonta a 2002, pelo Comitê de Demografia dos Povos Indígenas. ${ }^{5}$ Contando com a participação de antropólogos, demógrafos e profissionais da área da saúde coletiva, e com estreitas parcerias com o IBGE, a ABA e a Associação Brasileira de Saúde Coletiva (Abrasco) - em particular por intermédio do GT Saúde dos Povos Indígenas -, o GT Demografia dos Povos Indígenas no Brasil tem sido o principal polo articulador de eventos, reflexões, pesquisas e colaboração técnica (em particular com o IBGE) sobre a temática dos estudos populacionais acerca dos povos indígenas no país.

A fim de dar visibilidade à questão da demografia dos povos indígenas no Brasil, ao longo dos anos, membros do GT têm promovido diversas publicações, incluindo coletâneas, documentos técnicos e fascículos temáticos de periódicos científicos. Sem buscar ser exaustivos, podemos listar os seguintes trabalhos, que envolveram a colaboração entre participantes do GT: a coletânea Demografia dos Povos Indígenas no Brasil (Pagliaro, Azevedo G Santos, 2005); o volume Tendências Demográficas: uma análise dos indígenas com base nos resultados da amostra dos Censos Demográficos 1991 e 2000, da Série Estudos e Pesquisas do IBGE (IBGE, 2005); o dossiê temático 
"Povos indígenas do Brasil", no periódico Cadernos do CRH (Pagliaro, 2009); a coletânea La Población Afrodescendiente e Indígena en América Latina (Wong G Anton, 2014); o dossiê temático na Revista Brasileira de Estudos Populacionais (Cavenaghi, 2016; Santos, 2016). 6

Não é nosso objetivo neste texto apresentar uma revisão detalhada acerca dos temas cobertos nas principais publicações recentes sobre a demografia dos povos indígenas no Brasil. Entretanto, pode-se constatar uma certa identidade entre as propostas desses estudos e as diretrizes que norteiam as atividades do GT Demografia dos Povos Indígenas no Brasil, quais sejam: 1) o desenvolvimento de estudos e pesquisas sobre dinâmica demográfica dos povos indígenas com ênfase na interface com os conhecimentos antropológicos; 2) a reflexão sobre fontes e metodologias de coleta de informações; 3) a análise de séries históricas sobre indicadores de saúde e sociodemográficos para os povos indígenas (ver Santos et al., 2019 para uma recente revisão). É importante observar, também, que alguns desses trabalhos foram debatidos em versões preliminares em reuniões do GT. ${ }^{7}$

Alguns desses pontos remetem aos projetos político-acadêmicos delineados em décadas passadas. Ao mesmo tempo, as pesquisas contemporâneas oferecem novos contornos e significados às propostas que os antecedem, como esta coletânea pretende demonstrar. Para além de uma ideia de estudos sobre os povos indígenas, os capítulos dialogam, de forma menos ou mais explícita, com uma perspectiva (epistemológica) de realizar as investigações com os indígenas. ${ }^{8}$ Trata-se de uma distinção que não é trivial. Se toda demografia indígena é sobre os indígenas, posto que ela os têm como tema central de interesse, nem toda demografia indígena é produzida com os indígenas - isto é, buscando, ativa e criticamente, incorporar categorias indígenas em seus delineamentos e esquemas analíticos. Como bem notaram Caldwell e colaboradores (1987), a demografia se pauta por um conjunto de suposições antropológicas desenvolvidas em um período histórico específico do Ocidente (ver também Riley G McCarthy, 2003). Esses autores argumentam que uma das grandes contribuições que a antropologia pode oferecer à demografia é a expansão das bases teóricas desta a partir do estudo de outras sociedades e culturas. 9 Tem o potencial, portanto, de nos ajudar a estranhar a transposição, rotineira em estudos demográficos, de nossas concepções sobre mobilidade, rendimento, religião, entre tantas outras, para o universo indígena. Fazer uma demografia com os indígenas implica um contínuo exercício de reflexão nas várias etapas de pesquisa, considerando as inadequações de conceitos e metodologias - não com o objetivo de invalidar determinados dados, mas, sim, de produzir associações simétricas ou, ao menos, menos assimétricas (Latour, 1994; Stengers, 2002).

Tendo como pano de fundo as aludidas ligações genealógicas, entremeadas com sensibilidades teóricas que se consolidaram em períodos recentes nas interfaces 
entre antropologia e demografia, esta coletânea está estruturada em três partes. A primeira, Perspectivas a partir do Campo, é dedicada a trabalhos sobre dinâmicas populacionais com base em análises que consideram fenômenos específicos em seus contextos locais/regionais, e em diferentes fontes de informações demográficas.

O primeiro capítulo, intitulado "O Censo visto da aldeia: lendo dados demográficos com base na etnografia Apanjekra", de Bruno Nogueira Guimarães, alterna a apresentação de achados demográficos com hipóteses fundamentadas em estudos etnográficos. Guimarães busca compreender quais fatores levaram aos surpreendentes números registrados pelo Censo 2010 para a terra indígena (TI) Porquinhos, no Maranhão, que não correspondem aos levantamentos populacionais do autor ou aos dados de outros órgãos, como a Secretaria Especial de Saúde Indígena (Sesai) e a Funai. A partir do conhecimento de campo, dos sentidos dados pelos indígenas a determinadas categorias e de sua mobilidade pelo território, o pesquisador demonstra como a antropologia pode enriquecer a leitura das estatísticas. Ele também chama a atenção para os desafios da coleta de dados para indígenas nos censos demográficos, em especial dada a ausência de indígenas na construção e execução da pesquisa, que pode contribuir para a invisibilidade de dinâmicas populacionais de povos culturalmente diferenciados.

No capítulo "Dinâmica territorial e mobilidade espacial entre os Kaiowá e Guarani no Mato Grosso do Sul", Rosa Sebastiana Colman e Marta Azevedo apresentam uma análise da mobilidade indígena com base em resultados de uma pesquisa participativa com a população indígena estudada. As autoras abordam os fatores ligados aos deslocamentos indígenas e seus aspectos sociodemográficos, descrevendo e diferenciando as características específicas das "belas caminhadas" (ojeguata porã) e das migrações forçadas (ñemosarambipa). Colman e Azevedo mostram como os deslocamentos ocorrem em etapas e envolvem vários membros da família e pessoas de diferentes nacionalidades. Evidenciam também como as diferentes espacialidades indígenas e os movimentos Guarani e Kaiowá por variados territórios (dentro e fora das TIs, em diferentes países, entre cidades e fazendas) colocam desafios para o acesso às políticas públicas, sendo necessário compreender suas particularidades para a garantia dos direitos dessas populações.

Nas últimas décadas, foram conduzidas importantes pesquisas demográficas participativas com indígenas no Brasil, entre as quais o "Diagnóstico sociodemográfico participativo da população Sateré-Mawé", coordenado pelo demógrafo Pery Teixeira, é um exemplo marcante (Teixeira G Brasil, 2005). Os dados coletados no âmbito do "Diagnóstico" serviram de base para "Migração do povo indígena Sateré-Mawé em dois contextos urbanos na Amazônia", capítulo em que Pery Teixeira, Evelyne M. T. Mainbourg e Marília Brasil demonstram como a condução de censos locais e participativos permite considerar as dinâmicas locais de migração a partir da territorialidade nativa, constituindo-se em iniciativa inspiradora para o desenvolvimento de metodologias inclusivas. Oferecendo um 
panorama dos fluxos migratórios indígenas em diferentes contextos, os autores chamam atenção para o fato de que as dinâmicas populacionais indígenas devem ser analisadas em relação aos períodos históricos nos quais se inserem, indicando de que forma os diferentes padrões de mobilidade surgem (e desaparecem) na relação com o universo extracomunitário.

No capítulo "A política de transferência de renda condicionada e os povos indígenas no Brasil", Ricardo Verdum analisa os resultados de estudos etnográficos sobre os efeitos do Programa Bolsa Família (PBF) conduzidos em sete TIs em diferentes regiões do Brasil em 2013-2014. Na ocasião, o então Ministério de Desenvolvimento Social e Combate à Fome promoveu uma ampla pesquisa sobre as percepções indígenas acerca do PBF e das dinâmicas locais estabelecidas a partir do benefício social. Verdum, que atuou como coordenador executivo da pesquisa, compila alguns dos principais achados em seu texto, evidenciando como o programa influencia a relação dos indígenas com a educação formal, a saúde pública, o trânsito entre o interior das TIs e o seu exterior, entre outras dimensões. Apesar de não tratar diretamente com estatísticas populacionais, o trabalho aponta para os horizontes analíticos que se abrem quando programas, que em geral têm seus efeitos mensurados por informações quantitativas, são também examinados com abordagens qualitativas.

A segunda parte da coletânea, Dados Censitários em Contexto, reúne reflexões que lidam diretamente com estatísticas produzidas pelo IBGE. São textos que, de maneira crítica, abordam diferentes aspectos das pesquisas censitárias, tratando desde a metodologia de coleta de dados até a análise estatística dos indicadores.

Marden B. Campos, Bruna B. Cordeiro, Ítalo O. Matos e Diego R. Macedo apresentam um estudo detalhado dos resultados do Censo 2010 para uma localidade específica do país. O capítulo "Indígenas em Belo Horizonte: o uso dos dados de setores censitários para estudos intraurbanos" descreve a distribuição socioespacial da população declarada indígena na capital mineira e analisa as regiões de moradia desses habitantes. A metodologia empregada e as reflexões a ela associadas indicam as potencialidades para as investigações de populações minoritárias nas esferas intraurbanas a partir do Censo 2010. Com base no estudo de caso, os autores exemplificam como é possível caracterizar pelo menos dois perfis de indígenas em contextos urbanos: os que vivem em setores censitários de alta renda e escolaridade, espacialmente isolados de outros indígenas, e os que residem nos setores com maior presença indígena, em regiões de menor renda e maior analfabetismo.

Em "Declaração de idade em indígenas e não indígenas no Censo Demográfico de 2010", Barbara Coelho B. Cunha, Thatiana Fávaro, Luciene Guimarães de Souza, Ludimila Raupp, Geraldo Marcelo Cunha, Ricardo Ventura Santos realizam uma análise comparativa dos padrões de resposta entre indígenas e não indígenas para uma variável específica e central nos recenseamentos. Com foco na "forma de declaração de idade" (ou seja, verificando se o registro de idade foi a data de 
nascimento ou a idade declarada), os autores abordam resultados derivados da aplicação de modelagens estatísticas considerando diferentes variáveis independentes. Exploram também as dificuldades de tradução de determinadas categorias de um contexto sociocultural específico (qual seja, o ocidental, que informa a estruturação dos questionários censitários e sua aplicação) para outro (o dos indígenas), refletindo sobre quais fatores poderiam explicar as discrepâncias nos padrões de resposta de indígenas e não indígenas. As reflexões apresentadas têm o potencial fomentar debates sobre os complexos fatores envolvidos na captação de dados censitários em populações culturalmente diferenciadas.

Os autores do capítulo "Parturição em mulheres indígenas e não indígenas do Brasil: o número de filhos relatados depende de quem responde às perguntas do censo nacional?" também utilizam os dados censitárias de 2010 para avançar a reflexão antropológica e demográfica sobre coleta de dados entre populações indígenas. Ricardo V. Santos, João Luiz Bastos, Oswaldo G. Cruz, Luciene A. F. B. Longo, Nancy M. Flowers e Nilza O. M. Pereira têm como objetivo investigar se os padrões de resposta às perguntas sobre parturição (número de filhos) diferem entre indígenas e não indígenas, comparando se a resposta é fornecida diretamente pela mulher ou por um outro respondente. Utilizando dados das regiões Norte e Nordeste, os autores observaram que as médias de parturição foram mais elevadas quando os respondentes eram as próprias mulheres. Sinalizam também que, em comparação com as não indígenas, uma menor proporção de mulheres indígenas respondeu diretamente aos recenseadores, o que aponta para a influência em potencial da dinâmica da entrevista no ambiente domiciliar sobre os resultados censitários.

No capítulo "'Você se considera indígena?': características da população residente em terras indígenas investigadas pelo Censo Demográfico de 2010", Gerson Luiz Marinho, Ricardo Ventura Santos e Alessandra Traldi Simoni analisam resultados derivados de uma pergunta que foi pela primeira vez incluída no Censo 2010. O quesito "se considera" foi aplicado para os residentes em TIs que não se declararam "indígenas" na pergunta sobre "cor ou raça", com vistas a ampliar a captação da população indígena. Os achados apontam para diferentes perfis demográficos entre aqueles que se declararam indígenas na pergunta sobre cor ou raça e os que se consideraram como tal na pergunta de cobertura. Além disso, indicam as particularidades territoriais das respostas positivas para esta questão, concentradas em um conjunto relativamente reduzido de TIs. Os autores refletem sobre a metodologia censitária, indagando acerca das influências de contextos locais/ regionais nos quais se inserem as TIs no tocante aos padrões de resposta para a pergunta "se considera".

A terceira parte da coletânea amplia e projeta, tanto em direção ao passado quanto em alguma medida ao futuro, as reflexões sobre a demografia da população indígena. Em Trajetórias, Categorias, Implicações, os contextos históricos, as 
categorias de análise e suas consequências para os indígenas e as políticas públicas são consideradas.

No capítulo "'Convívio e contaminação': uma análise sócio-histórica sobre epidemias, demografia e povos indígenas na obra de Darcy Ribeiro", Carolina Arouca Gomes de Brito aborda um importante estudo acerca da demografia indígena no Brasil. A autora compara as três versões do clássico texto "Convívio e contaminação" (1955, 1956, 1970), indicando a originalidade da reflexão de Ribeiro sobre temas, como a ocorrência de doenças, redução populacional e impactos sobre a organização social, desenvolvidos com base em dados coletados nos anos 1940 e 1950. O resgate das reflexões de Ribeiro ilumina as raízes históricas dos estudos populacionais sobre os povos indígenas, evidenciando como a trajetória de instituições indigenistas e de seus técnicos está nos fundamentos do campo da demografia dos povos indígenas. Ao fazê-lo, a autora contribui para problematizar a complexa temática da saúde dos povos indígenas, demonstrando a maneira como análises históricas podem ser informativas para reflexões sobre cenários contemporâneos.

Em "Indígenas e pesquisa demográfica: sugestões ao debate sobre religião e indígenas no contexto do censo brasileiro", Elizabeth Pissolato se volta para o debate sobre visibilidade indígena com as categorias associadas a essas populações nas estatísticas oficiais. Suas reflexões se concentram na pergunta sobre religião no questionário do Censo Demográfico. A autora demonstra como, ao utilizar o termo "indígena" para qualificar um conjunto de expressões religiosas, as estatísticas oficiais projetam uma imagem própria sobre o significado da indianidade. A noção ocidental de religião, a definição de uma parcela da população como indígena e os trabalhos históricos e etnográficos sobre esse segmento populacional são elementos que ilustram a vultosa complexidade dos censos e colocam desafios para representação quantitativa dos indígenas e da diversidade de seus modos de vida.

Os dois últimos capítulos apresentam entrevistas com dois antropólogos que deram decisivas contribuições para o campo da demografia indígena: João Pacheco de Oliveira e Marta Maria do Amaral Azevedo.

Na entrevista de João Pacheco de Oliveira ("Os indígenas nos censos demográficos"), concedida à antropóloga Marta Antunes, o professor do Museu Nacional reflete criticamente sobre a captação de dados sobre povos indígenas nos censos demográficos e o futuro das estatísticas oficiais para populações minoritárias no país. A partir de sua vasta experiência com o tema, pondera sobre as articulações entre o conhecimento antropológico e o estudo das dinâmicas populacionais, as metodologias censitárias adotadas pelo IBGE e as mudanças nas formas de se retratar as populações indígenas ocorridas ao longo do tempo.

Na entrevista de Marta Maria do Amaral Azevedo ("Memórias acadêmicoafetivas sobre a demografia dos povos indígenas no Brasil"), conduzida por Alessandra Traldi Simoni, Bruno Nogueira Guimarães e Ricardo Ventura Santos, a 
demógrafa e antropóloga traça a história da organização e atuação do GT Demografia dos Povos Indígenas no Brasil da Abep, refletindo sobre momentos marcantes de sua trajetória profissional. Azevedo narra como o diálogo estabelecido por diferentes profissionais e instituições, ao longo das últimas décadas, foi indispensável para a consolidação da demografia indígena e para o refinamento dos métodos de captação de dados. Ao recordar seu envolvimento com o campo, do qual é uma das vozes mais proeminentes, Azevedo contribui para delinear a biografia de um projeto coletivo, que começou a ser gestado nas primeiras reuniões da Abep, há aproximadamente quarenta anos.

\section{Post-Scriptum: perspectivas para uma demografia indígena em 2019 e além}

No momento em que findamos a escrita desta Apresentação (maio de 2019), transcorre um intenso debate sobre as possibilidades de realização do Censo Demográfico de 2020. Em um cenário de forte crise econômica, discutem-se as consequências de se reduzir o número de perguntas nos questionários com vistas a diminuir os custos da operação censitária. ${ }^{10}$ Nesse contexto, manifesta-se a preocupação, expressa por organizações e associações, como a Abep, ABA, Abrasco e o Instituto Socioambiental (ISA), quanto aos impactos em potencial no tocante à produção de estatísticas acerca dos povos indígenas e outras populações "tradicionais":

Em um cenário sociopolítico no qual se aventa a possibilidade de não garantia de recursos para realização do Censo Demográfico de 2020, esta carta tem como objetivo expressar e reiterar a importância da manutenção das perguntas do bloco de identificação étnico-racial no próximo levantamento censitário. Ao longo das últimas décadas, houve um expressivo aumento na captação de dados relativos às populações indígenas nas estatísticas oficiais na América Latina. O caso brasileiro é exemplar neste sentido, o que ocorreu em larga medida devido à iniciativa do IBGE de inclusão da categoria "indígena" na pergunta sobre cor ou raça em 1991. Os dois censos demográficos seguintes (2000 e 2010) ampliaram de forma expressiva os conhecimentos sobre a população indígena no país (...). É fundamental que o Censo 2020 continue pesquisando sobre a composição étnico-racial da sociedade brasileira, incluindo também os quilombolas; esse é um compromisso social e político de consolidação de um Estado etnicamente plural, firmado na Constituição Federal de 1988, e um dos princípios consolidados internacionalmente para a produção de estatísticas oficiais (..... ${ }^{11}$

Abrimos esta Apresentação fazendo alusão a um estudo do início da década de 1980 da antropóloga Lux Vidal que mencionava a proposta de reformulação dos questionários e do tratamento do censo oficial para os povos indígenas, visando 
sobretudo a incluí-los nas estatísticas públicas. Entretanto, fechamos este texto, referindo-nos às incertezas quanto à permanência e à abrangência "das perguntas do bloco de identificação étnico-racial no próximo levantamento censitário" (ou seja, o Censo Demográfico de 2020). Em um ciclo de quatro décadas, partiu-se de uma situação de ausência de dados, trilhou-se uma trajetória de crescente visibilidade estatística e, preocupantemente, tem-se um cenário de reversão da curva de produção de dados demográficos sobre povos indígenas em uma das principais fontes de informações de estatísticas oficiais existentes no país. Ironicamente, nessa nova onda de "inquietude", como se depreende da carta cujo trecho transcrevemos, ocorre uma ativa participação da sociedade civil com vistas à permanência das perguntas sobre povos indígenas e outras populações tradicionais no Censo Demográfico de 2020. Esperamos que esta coletânea seja lida também como um manifesto pela crescente visibilização dos indígenas nas pesquisas demográficas e nas estatísticas públicas, com vistas a implementar políticas sociais adequadas e sensíveis para as realidades socioculturais desses povos.

Agradecemos ao editor executivo da Editora Fiocruz João Carlos Canossa Mendes, aos editores científicos Carlos Machado de Freitas e Gilberto Hochman, por todo o apoio durante a produção desta coletânea, e também a Phelipe Gasiglia pela produção editorial e a Maria Cecilia Moreira pela primorosa revisão dos textos. Eduardo Pina gentilmente realizou tratamento gráfico das fotografias apresentadas no capítulo 12. Agradecemos também o apoio e a ajuda de Ana Lucia Pontes, Carlos E. A. Coimbra Jr., James Welch e Hélio Sá nas várias fases do projeto editorial. Os comentários enviados pelos dois pareceristas anônimos foram de grande valia na preparação da versão final dos capítulos.

Os organizadores 
1 A demógrafa Alessandra Traldi Simoni, a partir de consulta a Vidal, recuperou em 2018 uma versão bastante mais detalhada (Vidal, 1982b) que as três páginas publicadas nos Anais (Vidal, 1982a).

2 A entrevista de Marta Azevedo neste volume aborda de forma detalhada a gênese e trajetória dos estudos demográficos sobre povos indígenas no âmbito da Abep.

3 Nos três anos seguintes, foram publicadas outras matérias no Porantim com dados demográficos sobre os povos indígenas (Cimi, 1980, 1982).

4 Diversas publicações do Cedi na época abordaram dados de contagem populacional dos povos indígenas no país (Cedi, 1981, 1982, 1983; Cedi/Museu Nacional, 1987).

5 Para mais informações, sugere-se consultar a página do GT (<www.abep.org.br/site/index. php/grupos-de-trabalho/demografia-dos-povos-indigenas-no-brasil/ementa $>$ ).

6 Cabe destacar que a produção acadêmica dos participantes do GT vai além do envolvimento nessas produções de caráter mais coletivo. Um projeto de pesquisa importante seria, a partir de perspectivas ligadas à história e antropologia da ciência, investigar a fundo a trajetória e produção dos membros do GT e o modo como estas se articulam com a elaboração e implementação de políticas públicas no país.

7 Esse é o caso dos capítulos 5, 6, 8 e 10, que são desdobramentos de apresentações feitas no encontro do GT Demografia dos Povos Indígenas no Brasil ocorrido, em 2017, no Centro de Desenvolvimento de Planejamento Regional da Universidade Federal de Minas Gerais. A entrevista com Marta Azevedo (capítulo 12) tem como base a sua conferência proferida na ocasião.

8 No Brasil, a diferenciação envolvida nas perspectivas "com" e "sobre" tem sido particularmente influente nos debates sobre ética na pesquisa antropológica (Sarti G Duarte, 2013). No âmbito das investigações demográficas com foco em povos indígenas, um exemplo é o recente volume sobre "identificação" indígenas em estatísticas oficiais publicado pelo Statistical Journal of the IAOS (Connoly, 2019; Condon, 2019). Em um dos textos dessa publicação, Connoly, pesquisadora indígena norte-americana da área da saúde e bioestatística, aborda a tendência recente de estudos estatísticos e demográficos realizados pelos povos indígenas, e não mais unicamente por ou para eles ("We could have research done 'by us' not 'for us' or 'to us'"Condon, 2019: 8). O livro organizado por Kukutai e Taylor (2016) é um outro exemplo recente que ilustra o protagonismo das populações nativas/indígenas no tocante à produção, análise e gerenciamento de informações demográficas.

9 Campos e Estanislau (2016: 442-443) apresentam uma reflexão nessa linha, mas abordando especificamente a questão da captação de dados acerca dos povos indígenas nos censos demográficos nacionais recentes realizados no Brasil. Segundo eles, "embora os questionários dos Censos incorporem cada vez mais possibilidades de resposta que se aproximam das formas de organização social de alguns povos indígenas, eles captarão melhor, obviamente, as características daqueles indígenas que mais se assemelham ao que estamos aqui chamando de 'brasileiro médio'. (...) aqueles indivíduos cuja organização social ou o horizonte cognitivo 
diferem substancialmente dos conceitos utilizados nos Censos possivelmente terão sua captação prejudicada na pesquisa. Importante ressaltar que isso vale também para outros grupos étnicos, estrangeiros ou mesmo grupos socioeconômicos menos favorecidos".

10 A partir de janeiro de 2019, esse tema passou a ser amplamente debatido nos mais variados meios de comunicação do país, incluindo-se as redes sociais.

11 Carta intitulada "Importância da manutenção das perguntas do bloco de identificação étnicoracial no Censo Demográfico de 2020", dirigida à Presidência do IBGE e preparada pelo GT Demografia dos Povos Indígenas no Brasil da Abep, com apoio da Abrasco, ISA e ABA. Foi redigida durante o XXI Encontro Nacional de Estudos Populacionais da Abep, ocorrido em Poços de Caldas (MG), de 22 a 28 de setembro de 2018.

\section{Referências}

AXELSSON, P. G SKÖLD, P. (Orgs). Indigenous Peoples and Demography: the complex relation between identity and statistics. New York, Oxford: Berghahn, 2011.

BARBOSA, J. M. A. G FAGUNDES, M. G. Brasil: uma revoada de pássaros - o protagonismo indígena no processo Constituinte. Revista Brasileira de História G Ciências Sociais, 10(20): 175-196, 2018.

CALDWELL, J. et al. Anthropology and demography: the mutual reinforcement of speculation and research. Current Anthropology, 28(1): 25-43, 1987.

CAMPOS, M. B. G ESTANISLAU, B. R. Demografia dos povos indígenas: os censos demográficos como ponto de vista. Revista Brasileira de Estudos de População, 33(2): 441-449, 2016.

CARNEIRO DA CUNHA, M. Cultura com Aspas e Outros Ensaios. São Paulo: Cosac Naify, 2009.

CARNEIRO DA CUNHA, M. et al. Indigenous peoples boxed in by Brazil's political crisis. HAU: Journal of Ethnographic Theory, 7(2): 403-426, 2017.

CAVENAGHI, S. Nota da Editora: Dados e mais dados "para não deixar ninguém para trás". Revista Brasileira de Estudos Populacionais, 33(2): 223-230, 2016.

CENTRO ECUMÊNICO DE DOCUMENTAÇÃO E INFORMAÇÃO (CEDI). Povos Indígenas no Brasil 1980. São Paulo: Cedi, 1981. (Aconteceu, v. 6)

CENTRO ECUMÊNICO DE DOCUMENTAÇÃO E INFORMAÇÃO (CEDI). Povos Indígenas no Brasil 1981. São Paulo: Cedi, 1982. (Aconteceu, 10 de abril)

CENTRO ECUMÊNICO DE DOCUMENTAÇÃO E INFORMAÇÃO (CEDI). Povos Indígenas no Brasil 1982. São Paulo: Cedi, 1983. (Aconteceu, 12 de abril)

CENTRO ECUMÊNICO DE DOCUMENTAÇÃO E INFORMAÇÃO (CEDI). Museu Nacional. Terras Indígenas no Brasil. Rio de Janeiro: Museu Nacional G Cedi: São Paulo, 1987. 
CENTRO ECUMÊNICO DE DOCUMENTAÇÃO E INFORMAÇÃO (CEDI). Povos Indígenas no Brasil 1987/88/89/90. São Paulo: Cedi, 1991.

CONDON, K. M. Interview with Michele Connolly. Statistical Journal of the IAOS, 35: 5-12, 2019.

CONNOLY, M. Guest editorial. Statistical Journal of the IAOS, 35: 13-14, 2019.

CONSELHO INDIGENISTA MISSIONÁRIO (CIMI). Dossiê sobre a situação dos povos indígenas em todo o Brasil, com levantamento demográfico atualizado (210.000 índios). Porantim, ano II, n. 11, p. 1-11, 1979.

CONSELHO INDIGENISTA MISSIONÁRIO (CIMI). Levantamento da realidade indígena. Porantim, ano III, n. 23, p. 1-10, 1980.

CONSELHO INDIGENISTA MISSIONÁRIO (CIMI). Estatística: índios que sobrevivem e terras que lhes restam. Quantos são os sobreviventes? Um retrato de nossa população indígena. Porantim, ano IV, n. 38, p. 3-13, 1982.

DAVIS, S. Vítimas do Milagre: o desenvolvimento e os índios do Brasil. Rio de Janeiro: Jorge Zahar, 1978.

GOMES, M. P. Os Índios e o Brasil: ensaio sobre um holocausto e sobre uma nova possibilidade de convivência. Petrópolis: Editora Vozes, 1988.

INSTITUTO BRASILEIRO DE GEOGRAFIA E ESTATÍSTICA (IBGE). Tendências Demográficas: uma análise dos indígenas com base nos resultados da amostra dos Censos Demográficos de 1991 e 2000. Rio de Janeiro: IBGE, 2005.

KERTZER, D. I. G AREL, D. (Eds.). Census and Identity: the politics of race, ethnicity, and language in the national censuses. Cambridge: Cambridge University Press, 2002.

KUKUTAI, T. G TAYLOR, J. (Eds.). Indigenous Data Sovereignty: toward an agenda. Canberra: Australian National University Press, 2016.

LATOUR, B. Jamais Fomos Modernos. São Paulo: Editora 34, 1994.

LOVEMAN, M. National Colors: racial classification and the state in Latin America. New York: Oxford University Press, 2014.

MARTINS, E. Nossos Índios, Nossos Mortos: os olhos da emancipação. São Paulo: Codecri, 1982.

McSWEENEY, K. G ARPS, S. A "Demographic turnaround": the rapid growth of indigenous populations in Lowland Latin America. Latin American Research Review, 40(1): 3-29, 2005.

OLIVEIRA, J. P. Mensurando alteridades, estabelecendo direitos: práticas e saberes governamentais na criação de fronteiras étnicas. Dados, 55: 1.055-1.088, 2012.

PAGLIARO, H. Povos indígenas do Brasil: introdução. Cadernos de CRH, 22(57): 447-450, 2009.

PAGLIARO H.; AZEVEDO M. M. G SANTOS, R. V. (Orgs.). Demografia dos Povos Indígenas no Brasil. Rio de Janeiro: Editora Fiocruz, Abep, 2005. 
PENNA, T. Por que demografia indígena brasileira? In: ENCONTRO NACIONAL DE ESTUDOS POPUlACIONAIS, IV, Águas de São Pedro, 1984. Anais... São Paulo: Abep, 1984.

RAMOS, A. R. Indigenism: ethnic politics in Brazil. Madison: Wisconsin University Press, 1998.

RIBEIRO, D. Os Índios e a Civilização: a integração das populações indígenas no Brasil moderno. Petrópolis: Vozes, 1977.

RICARDO, C. R. G RICARDO, F. Povos Indígenas no Brasil 2011-2016. São Paulo: Instituto Socioambiental, 2017.

RILEY, N. E. G McCARTHY, J. Demography in the Age of the Postmodern. Cambridge: Cambridge University Press, 2003.

SANTOS, R. V. Prólogo ao dossiê "Demografia dos povos indígenas no Brasil: abordagens socioantropológicas". Revista Brasileira de Estudos Populacionais, 33(2): 231-235, 2016.

SANTOS, R. V. et al. The identification of the indigenous population in Brazil's official statistics, with an emphasis on demographic censuses. Statistical Journal of the IAOS, 35(1): 26-49, 2019.

SARTI, C. G DUARTE, L. F. D. (Orgs.). Antropologia e Ética: desafios para a regulamentação. Brasília: Associação Brasileira de Antropologia, 2013.

SOUZA LIMA, A. C. Um Grande Cerco de Paz: poder tutelar, indianidade e formação do Estado no Brasil. Petrópolis: Vozes, 1995.

STENGERS, I. A Invenção das Ciências Modernas. São Paulo: Editora 34, 2002.

TEIXEIRA, P. G BRASIL, M. Estudo demográfico dos Sateré-Mawé: um exemplo de censo participativo. In: PAGLIARO H.; AZEVEDO M. M. G SANTOS, R. V. (Orgs.). Demografia dos Povos Indígenas no Brasil. Rio de Janeiro: Editora Fiocruz, Abep, 2005.

VALENTE, R. Os Fuzis e as Flechas: história de sangue e resistência indígena na ditadura. São Paulo: Companhia das Letras, 2017.

VIDAL, L. Demografia dos grupos étnicos minoritários: índios. In: ENCONTRO NACIONAL DE ESTUDOS POPULACIONAIS, III, 1982, Águas de São Pedro. Anais... São Paulo: Abep, 1982 .

VIDAL, L. (Org.). Demografia dos grupos étnicos minoritários: índios. In: ENCONTRO DA ASSOCIAÇÃO BRASILEIRA DE ESTUDOS POPULACIONAIS, III, 11-14 out. 1982b, Vitória.

WONG, L. Resumo das discussões sobre o tema "etnia e população". In: ENCONTRO NACIONAL DE ESTUDOS POPULACIONAIS, IV, Águas de São Pedro, 1984. Anais... São Paulo: Abep, 1984.

WONG, L. G ANTON, J (Orgs.). Situación de la Población Afro-Descendiente y Indígena en América Latina: puntos de reflexión para el debate sobre Cairo + 20. Belo Horizonte: Asociación Latinoamericana de Población, Alap, 2014. 
Perspectivas a partir do Campo 


\section{O Censo Visto da Aldeia: lendo dados demográficos com base na etnografia Apanjekra*}

Este texto é escrito como um experimento de leitura dos dados do Censo Demográfico 2010 com base no meu conhecimento etnográfico adquirido entre os Canela Apanjekra ao longo da última década. Entre 2011 e 2016, passei 14 meses com os Apanjekra, realizando trabalho de campo na aldeia Porquinhos. Esta é a única aldeia da terra indígena (TI) Porquinhos, localizada nos municípios maranhenses de Barra do Corda e Fernando Falcão. Os Canela Apanjekra são falantes da língua timbira, a mesma língua falada pelos Canela Ramkokamekra, Krintaki, Krahô e Gavião. Estes povos compartilham seu complexo ritual, com festas sazonais comuns que envolvem membros de diferentes aldeias em uma sofisticada rede de troca (que abrange o matrimônio entre membros de aldeias distintas, a circulação de conhecimentos rituais e o intercâmbio de espécies vegetais cultivadas).

A organização social dos povos Timbira segue princípios estruturantes comuns, pautados por um padrão de residência uxorilocal (o marido mora com a esposa na residência dos sogros dele) e por um parentesco de tipo crow-omaha que inclui também a transmissão de nomes de cognatos cruzados que determinam posições e prerrogativas sociais (Ladeira, 1982; Lave, 1979, Melatti, 1976). Estes atributos comuns fundamentam o que Azanha (1984) chama de "forma timbira". Uma diferença atual entre os Canela (Apanjekra e Ramkokamekra) e os demais Timbira (em especial Gavião e Krahô) é que, enquanto estes últimos multiplicam aceleradamente suas aldeias (em março de 2018 os Gavião tinham 16 aldeias, a mais antiga criada em 1984, e as 12 mais recentes fundadas a partir de 2012), os primeiros possuem apenas uma aldeia por TI há décadas. Essas populações aumentam significativamente ano após ano, como é reconhecido pelos próprios indígenas, e cada povo escolhe sua estratégia territorial mais adequada para gerir o próprio crescimento.

Um dos objetivos deste capítulo é demonstrar que os dados demográficos podem contribuir não apenas para a descrição e o entendimento da realidade etnográfica já conhecida pelo antropólogo, como também para ajudá-lo a formular hipóteses de pesquisa com base em dados que ele não costuma acessar. Apesar de esta ideia parecer óbvia, poucos antropólogos brasileiros se debruçam sobre as 
informações demográficas disponíveis sobre os povos estudados. Pretendo indicar também como a consideração qualitativa de contextos específicos enriquece a análise demográfica e, potencialmente, permite sanar dúvidas na interpretação dos dados. Esta contribuição se funda em duas observações. A primeira, a de que os questionários dos censos, tais quais os de qualquer outra pesquisa, são fruto de um contexto específico em que se encontram o ideário da nação, a busca por reconhecimento identitário e as lutas políticas de diferentes segmentos sociais por direitos (Loveman, 2014; Thompson, 2016). Suas questões não são de entendimento universal, e a compreensão de quem as responde pode diferir daquilo que o Instituto Brasileiro de Geografia e Estatística (IBGE) planejava captar com as perguntas (Campos G Estanislau, 2016).

A segunda observação diz respeito ao fato de que as teorias demográficas são elaboradas com base em dinâmicas populacionais derivadas de contextos de tempo e espaço específicos, com particularidades que não podem ser necessariamente generalizadas. As maiores contribuições para a demografia canônica vieram do estudo de populações do Ocidente moderno, ajudando a consolidar um conjunto de suposições demográficas que não incluem necessariamente as populações de baixa escala ou que se diferenciam culturalmente (Caldwell et al., 1987). Cotejar os dados censitários com o conhecimento etnográfico é uma via para incorporar as discussões antropológicas nas teorias sobre dinâmicas populacionais e nas análises censitárias.

O diálogo entre os dados quantitativos (captados pelo Censo Demográfico 2010 e acessados no Bando Multidimensional de Estatística do IBGE) e qualitativos (resultantes de pesquisa etnográfica) será construído a partir da justaposição de considerações etnográficas e informações estatísticas, ora contrastando-as, ora apresentando a forma como se complementam. Considerando os dados censitários da TI Porquinhos, indicarei como a produção de dados estatísticos é fruto de interações que ocorrem em um contexto específico e como as categorias e dinâmicas nativas podem ser pouco captadas pelas estatísticas oficiais, contribuindo para a invisibilidade de populações culturalmente diferenciadas. Ao mesmo tempo, etnólogos e demais pesquisadores que conduzem pesquisas com foco em uma localidade muito específica podem perder de vista as características das vizinhanças do campo, que entenderiam melhor com base em observação das informações demográficas.

\section{O enigma Porquinhos no Censo 2010}

A TI Porquinhos se localiza em dois municípios, Barra do Corda e Fernando Falcão, estando a única aldeia da TI nos limites territoriais deste último. Meu primeiro levantamento populacional, em 2012, captou 690 habitantes em 97 
residências na aldeia Porquinhos. ${ }^{1}$ Um novo levantamento, em 2016, contabilizou 113 residências para 758 pessoas (outras 5 novas residências eram construídas durante minha pesquisa). Em 2019, outra pesquisa realizada por mim e pelo economista Caio Bibiani identificou 843 habitantes em 124 moradias. Apesar de os Apanjekra afirmarem ser aproximadamente 700 pessoas, em concordância com as estimativas dos funcionários locais da Fundação Nacional do Índio (Funai) e da Secretaria Especial de Saúde Indígena (Sesai), o Censo 2010 contabilizou 2.600 indivíduos na TI. Esses dados desafiam o pesquisador que vai a campo: não há dado etnográfico da população dos Apanjekra que sequer se aproxime de metade dos indivíduos registrados na TI Porquinhos no Censo 2010 (para a análise das variações demográficas dos Canela Ramkokamekra, vizinhos da TI Porquinhos, ver Greene G Crocker, 1994). Também não há documentação administrativa indicando uma população indígena tão numerosa, ainda que os próprios Apanjekra informem que são atualmente mais numerosos do que nas décadas anteriores (Guimarães, 2012). Nenhum fenômeno demográfico, sozinho, parece explicar a magnitude da discrepância entre o que o etnógrafo encontraria em 2010 na TI Porquinhos e o registrado pelas estatísticas censitárias.

Antes de formularmos hipóteses, é importante entender o processo de captação de dados do Censo 2010. A metodologia consiste em entrevistas sobre as características de cada domicílio, tomando como referência o dia 31 de julho de 2010. Os dados de cada morador são coletados pelo recenseador ao entrevistar um morador do domicílio a partir de um questionário padronizado. Dentre outros pontos, o informante responde a uma pergunta sobre a "cor ou raça" dos habitantes do domicílio. Esta é a questão que nos interessa neste primeiro momento: pautada pelo princípio da classificação informada (o informante declara sua cor ou raça e também a dos seus corresidentes), ela nos permite identificar quantas pessoas se afirmaram indígenas para os recenseadores. Em 2010, houve uma novidade em relação aos censos anteriores: quando o questionário era aplicado dentro da TI e o respondente escolhia uma opção diferente de "indígena" no quesito "cor ou raça" (ou seja, "branco", "preto", "pardo" ou "amarelo"), uma nova pergunta era realizada:2 "você se considera indígena?". Esta era uma "pergunta de cobertura", destinada a captar indígenas que tinham, por qualquer motivo, escolhido outra resposta para a questão anterior (Pereira, 2017). Para os efeitos deste texto, trataremos como "declarados" indígenas aqueles que escolheram esta resposta no quesito "cor ou raça". Aqueles que "se consideraram" indígenas serão aqueles que responderam afirmativamente à pergunta de cobertura após terem escolhido outra opção para "cor ou raça" (como a questão "se considera" só pode ser realizada para quem não se declarou indígena, não é possível haver uma pessoa que se declarou e se considerou indígena). No Censo 2010, 817.963 pessoas se declararam indígenas e outras 78.954 se consideraram indígenas em todo o território nacional (IBGE 2012a). 
Entender se há diferença no perfil de ambos os grupos é uma questão importante que é explorada por outros pesquisadores. ${ }^{3}$

Caso o informante respondesse ser "indígena" no quesito "cor ou raça" ou "se considerasse" indígena na pergunta subsequente, outras duas novas questões eram feitas: "qual a sua etnia ou o povo a que pertence?" e "fala língua indígena no domicílio?" (em caso afirmativo, era possível registrar até duas línguas indígenas) (IBGE 2012a). Como destacou Azevedo (2017), essas inovações permitiram produzir indicadores específicos para determinadas etnias e, de forma geral, compreender as diferentes dinâmicas demográficas entre dois perfis de declarações de "indígenas", divisados com base na informação ou não do pertencimento étnico. A sofisticação do Censo 2010 em relação aos anteriores, que não apresentavam a pergunta de cobertura ou as sobre etnia e língua indígena, levou a um ganho tanto de informação quanto de complexidade na análise dos resultados. Para refletirmos sobre os dados obtidos, é necessário considerar o contexto da aplicação do questionário.

Em 31 de julho de 2010, a TI Porquinhos se intitulava TI Porquinhos dos Canelas-Apanyekra, em decorrência do processo de ampliação de seus limites (passando a área da TI de 79.500 para 300.000 hectares). A primeira demarcação, homologada em 1983, não contemplou diversas áreas tradicionais indígenas, como setores de roça, regiões de caça e espaços de aldeias antigas ocupadas pelos Apanjekra. Um exemplo é a exclusão da TI Porquinhos da região da aldeia Chinela, palco de um massacre ocorrido no início do século XX, quando dezenas de pessoas foram assassinadas e os sobreviventes fugiram para outras aldeias Timbira. Dentre as diversas controvérsias presentes na primeira demarcação, estava a fraude de memoriais descritivos e de mapas, em que os agentes da Funai ignoraram as indicações de indígenas e de antropólogos envolvidos no processo (Guimarães, 2012). O resultado foi o estabelecimento de limites equivocados que, ao invés de garantir o direito indígena à terra, consolidou o território usurpado como domínio de invasores.

A revisão dos limites da TI, iniciada anos 2000, 4 teve sua portaria declaratória expedida pelo Ministro da Justiça em outubro de 2009. As prefeituras locais contestaram judicialmente a ampliação da TI e foram derrotadas em abril de 2010, por votação unânime no Supremo Tribunal de Justiça (STJ). Nesse momento, a desintrusão da TI estava pendente, razão pela qual muitos dos habitantes captados pelo Censo 2010 não eram habitantes da aldeia Porquinhos. Como o Supremo Tribunal Federal, em 2014, acolheu a contestação das administrações municipais maranhenses, dando a estas ganho de causa, a TI Porquinhos deixou de contar com a maior parte dos territórios indígenas que foram usurpados ao longo do século XX (Guimarães G Guerra, 2017). Os ministros do Supremo não avaliaram o mérito da ação: antes, pautaram sua decisão por uma das condicionantes que impuseram ao processo de Raposa Serra do Sol, em 2008, quando definiram que, se o Executivo não cumprisse o prazo cinco anos para concluir os processos demar- 
catórios, previsto no Estatuto do Índio, esses processos perderiam a validade legal (Brasil, 1973, 2008, 2014).

Ou seja, quando o IBGE realizou a coleta censitária, trabalhou com um território, bastante mais amplo, que correspondeu legalmente à TI Porquinhos apenas entre 2009 e 2014. Mesmo nesse período, os indígenas permaneceram em uma única aldeia, cercados pelos povoados dos invasores. A partir de 2014, a TI voltou a abarcar os mesmos 79.500 hectares que tinha antes de 2009, confinando os Apanjekra às áreas que não haviam sido invadidas até a década de 1970. Os 300 mil hectares a que ela deveria corresponder, considerados em 2010 pelo IBGE, a tornaria contígua a outras duas TIs: a TI Kanela, dos Canela Ramkokamekra, e a TI Bacurizinho, dos Tenetehara. Além da captação de toda a população não indígena no Censo 2010, em virtude de o IBGE considerar (corretamente) a área ampliada que nunca passou pela desintrusão, pode ter havido um erro de inclusão de outros habitantes indígenas, vizinhos, na TI Porquinhos.

Essa hipótese ganha força ao notarmos que foram registradas duas etnias para a TI em questão, Kanela e Tenetehara. ${ }^{5}$ Também foram contabilizadas quatro línguas indígenas faladas no domicílio: kanela, timbira, guajajara e tenetehara. ${ }^{6}$ Quando os primeiros dados do Censo 2010 foram publicados, alguns profissionais que atuavam na região consideraram a possibilidade de que vários moradores da TI Bacurizinho teriam sido incluídos na TI Porquinhos. Assim, teríamos três perfis distintos de identificação étnica: os Apanjekra (Canela), os Tenetehara (Guajajara) e os não indígenas. Esse conjunto de circunstâncias não apenas explicaria o aumento significativo da população, como também a heterogeneidade das declarações de cor ou raça, divididas em três padrões de respostas distintas: 587 habitantes da TI Porquinhos se declararam indígenas; 1.176 não se declararam indígenas, mas se consideraram como tal; 817 não se declararam nem se consideraram indígenas (Tabela 1).7

A hipótese de que os três perfis de declaração correspondessem às três distintas identificações étnicas, contudo, não se sustenta com base nos dados de etnia. Como se vê na Tabela 1, a quantidade de declarados Tenetehara é pequena. Esse fato também reduz a probabilidade de haver uma captação equivocada de domicílios dos Tenetehara na TI contígua a Porquinhos. A declaração de etnia também destaca outro ponto importante: 99,5\% dos indivíduos que indicaram pertencimento étnico se declararam indígenas em "cor ou raça" na TI Porquinhos. 
Tabela 1 - Frequências de pessoas segundo declaração de cor ou raça, se considera e etnia - TI Porquinhos (MA). Censo Demográfico 2010

\begin{tabular}{|c|c|c|c|c|c|c|c|c|}
\hline \multicolumn{3}{|c|}{ Cor ou raça indígena } & \multicolumn{3}{|c|}{ Se considera indígena } & \multicolumn{3}{|c|}{ Etnia } \\
\hline & $\mathrm{N}$ & $\%$ & & $\mathrm{~N}$ & $\%$ & & $\mathrm{~N}$ & $\%$ \\
\hline \multirow{2}{*}{ Sim } & \multirow{2}{*}{587} & \multirow{2}{*}{$22,6 \%$} & \multirow{2}{*}{$\mathrm{NA}^{*}$} & \multirow{2}{*}{\multicolumn{2}{|c|}{-}} & Kanela & 583 & $99,0 \%$ \\
\hline & & & & & & Tenetehara & 4 & $0,5 \%$ \\
\hline \multirow{3}{*}{ Não } & \multirow{3}{*}{2.015} & \multirow{3}{*}{$77,4 \%$} & Sim & 1.176 & $58,3 \%$ & Tenetehara & 3 & $0,5 \%$ \\
\hline & & & Não & 817 & $40,6 \%$ & \multirow{2}{*}{$\mathrm{NA}^{*}$} & \\
\hline & & & Ignorado & 22 & $1,1 \%$ & & & \\
\hline
\end{tabular}

${ }^{*} \mathrm{NA}=$ não se aplica

Fonte: elaborado pelo autor com base em dados do IBGE, disponíveis no Banco Multidimensional de Estatísticas.

\section{Hipóteses identitárias}

Embora seja possível inferir que aos Apanjekra correspondam às 583 pessoas que se declararam Kanela na TI Porquinhos, esse número é muito inferior às cerca de 700 pessoas encontradas nas visitas à aldeia. Assim, não se pode descartar a possibilidade de que muitos indígenas tenham sido captados apenas pela pergunta de cobertura e não tenham declarado etnia. A seguir, indico algumas hipóteses que podem explicar por que os Apanjekra poderiam não se identificar como indígenas em um primeiro momento. Algumas dessas hipóteses foram discutidas com outros antropólogos e funcionários do poder público (Funai, Ministério do Desenvolvimento Social e Combate à Fome e Ministério do Meio Ambiente), surpresos pelos dados da TI Porquinhos indicados pelo Censo 2010. Articulo essas ideias com minhas considerações etnográficas para debater a pertinência e os pressupostos de cada uma.

A primeira hipótese está associada à percepção da pergunta como ligada à tonalidade da pele, reforçada pelo fato de que a única categoria que não indica uma cor, justamente a "indígena", ser a última a ser lida pelo entrevistador. Nesse caso, não haveria contradição em dizer "minha pele é parda, negra, branca ou amarela e eu me considero índio". A questão está, portanto, nos entendimentos possíveis da pergunta por parte do entrevistado: se ela se refere a identidades sociologicamente significativas (caso em que haveria "identidade branca", "identidade parda" e assim por diante) ou a atributos fenotípicos indicadas por algumas características no corpo da pessoa, em que se destaque a cor da pele. ${ }^{8}$ Nesse sentido, os Apanjekra poderiam formular que são indígenas com pele de uma certa cor porque eles classificam os não indígenas de forma semelhante: kupen, palavra reservada para a 
população não índia e traduzida pelos Apanjekra por "branco", recebe um acréscimo caso se deseje especificar o tom da pele do kupen referido. Assim, uma pessoa de pele escura é chamada kupen-tuk, que traduzem para o português como "branco preto". A palavra em português "branco" pode denotar tanto uma cor como a não indianidade, especialmente no contexto do contato interétnico. Doravante, seria possível também que um Apanjekra se visse como "índio pardo", já que "índio" indica uma identidade e não a pigmentação da pele. Portanto, não haveria problema em se declarar uma cor de pele qualquer e, então, se considerar indígena na pergunta seguinte. É importante destacar que o tom da pele dos indígenas e da pele de muitos não indígenas pode ser semelhante, e ambos poderiam se classificar da mesma forma se utilizassem este critério para responder à pergunta.

A segunda hipótese está fundada no preconceito contra indígenas e no contexto em que o Censo 2010 ocorreu. As relações interétnicas locais e a relação com agentes do Estado é marcada pela discriminação contra os indígenas. Os Apanjekra relatam diversos casos em que sofreram violência física e simbólica na relação com os não indígenas. Não se declarar indígena é uma estratégia de controlar os danos decorrentes do racismo, que compreendem atendimentos médicos precários, dificuldade de acesso à educação, humilhações públicas e mesmo atentados contra a vida. Quando os recenseadores estiveram em Porquinhos, em 2010, os Apanjekra temiam um ataque à aldeia por conta das disputas fundiárias. Com a publicação da portaria declaratória de ampliação da TI, no final de 2009, moradores do povoado Serra Branca (nos limites da TI) ameaçaram os Apanjekra e baniram os estudantes indígenas da única escola da região com ensino médio. Ligações anônimas eram recebidas nos telefones públicos instalados em Porquinhos, em que não indígenas ameaçavam que cercariam a aldeia de madrugada e promoveriam um genocídio como o da aldeia Chinela, ocorrido no início do século XX, no qual morreram dezenas de Apanjekra (Guimarães, 2017: 41-42). Quando, no início de 2010, o STJ concedeu um mandado de segurança às administrações locais, suspendendo os efeitos da portaria declaratória, diversas picapes invadiram o pátio da aldeia. Eram fazendeiros que ostentavam cópias do mandado de segurança e armas de fogo. Falaram aos Apanjekra que a justiça tinha reconhecido que ali não era lugar de índio e que os papéis dos indígenas eram mais fracos que os dos brancos, e que também tinham melhores armas. Soltaram fogos de artifício e ameaçaram massacrar a aldeia caso os indígenas insistissem em recuperar os seus domínios tradicionais.

O Censo 2010 foi realizado em meio a esse conflito latente, às vésperas de uma guerra que não chegou a eclodir. Com indígenas ameaçados na cidade e evitando transitar em algumas regiões do sertão maranhense, esconder a identidade étnica era uma estratégia de sobrevivência. Em 2013, quando o tema da disputa fundiária voltou à tona em virtude da chegada à região dos técnicos responsáveis pela demarcação física, dois Apanjekra quase foram linchados em Barra do Corda. 
Eles tiveram que se identificar como Ramkokamekra, dizendo que não eram da TI Porquinhos, e sim da TI Kanela, e só foram salvos quando um não indígena intercedeu por eles. Esse tipo de acontecimento ilustra o custo da identificação étnica em um cenário conflituoso e ajuda a entender por que muitas pessoas podem se identificar como indígenas, mas não mencionar o pertencimento a um povo específico. Se essa leitura for correta, compreende-se melhoro motivo de as pessoas que se consideraram indígenas na questão de cobertura (mas não em "cor ou raça") não terem indicado etnia.

Uma terceira hipótese dialoga com um conjunto de pesquisas amazônicas sobre a noção de "virar branco", que apontam como a percepção nativa do que significa ser não indígena ultrapassa a diferença étnico-identitária. Na formulação de diversos pesquisadores, a distinção mais profunda entre "indígenas" e "não indígenas" estaria em suas capacidades diferenciais de atuar sobre o mundo. Ser "branco" compreende o domínio de um conjunto de saberes e práticas específicas, não contraditórios com os saberes e práticas indígenas. Há diversos casos etnográficos que indicam que essas noções não são mutuamente excludentes, como a percepção wari' de que se pode ser índio e "branco" (Vilaça, 2000), ou o gradiente de transformações yanomami, que localiza a pessoa entre um polo yanomami e um polo "branco", permitindo que a pessoa condense elementos dessas duas humanidades (Kelly, 2005). Os Apanjekra classificam os humanos em alguns grandes grupos, dos quais dois se destacam: mehin e kupen. Ao primeiro correspondem os Timbira, que, além de incluírem os Canela (Apanjekra e Ramkokamekra), contam com os Krahô, Krinkati e Gavião. A identificação comum a esses povos decorre da proximidade linguística (todos falam a língua timbira), do aparato ritual comum e dos mesmos princípios de organização social - todos esses fatores contribuem para uma percepção de corpos semelhantes, resultados de um mesmo processo de produção.

Essa ideia, expressa no termo mehin, "nossa carne", fundamenta a "forma timbira" (Azanha, 1984) e corresponde a uma noção de pessoa que se pauta por uma humanidade compartilhada, expressa no corpo (Coelho de Souza, 2001, 2004). Para os Timbira, os kupen são descendentes dos mehin, como narra o mito de Aukê (Carneiro da Cunha, 2009; Crocker, 1990; Crocker G Crocker, 2009; Guimarães, 2017; Matta, 1970): um jovem indígena, após ser traído e assassinado pelo seu povo, é lançado à fogueira. As chamas transformam o seu corpo e, no dia seguinte ao assassinato, quando os pais de Aukê procuram o cadáver do filho, encontram uma moradia diferente. Nela, está Aukê, transformado em kupen. Ele apresenta aos pais todas as suas criações, os bens e mercadorias dos não indígenas. Também apresenta aos mehin outras invenções suas, como a espingarda e os utensílios culinários dos kupen. Ao final do mito, por medo da arma de fogo, os indígenas escolhem caçar com o já conhecido arco, razão pela qual Aukê fornece suas inovações tecnológicas apenas aos seus descendentes kupen. Como demonstrado no mito e em consonância 
com os estudos etnológicos, a percepção da diferença entre os indígenas e os não indígenas está associada a transformações do corpo, em seus aspectos tangíveis e intangíveis (Seeger, Matta G Viveiros de Castro, 1987), e à capacidade criativa e tecnológica de cada um.

Tais distinções não estão limitadas à narrativa mítica. Em uma de minhas primeiras viagens acompanhando os Apanjekra no sertão maranhense, visitamos um pequeno povoado não indígena. Como era frequentemente confundido com um técnico do processo de ampliação da TI, um dos habitantes me convidou para um café em sua casa e começou a falar sobre a demarcação. Ele me disse: "nós também estamos aqui faz muito tempo, eu nasci nesta terra, conheço os índios desde criança, eles sempre passavam por aqui e pediam pouso". Depois de pedir que os Apanjekra confirmassem o fato, arrematou: "isso de branco e índio... nosso corpo é igual, é gente do mesmo jeito". Uma das lideranças indígenas ponderou: "a carne pode até ser igual, mas o sangue é diferente". Mais tarde, pedi que me explicasse essa frase, que não recebeu atenção do sertanejo que nos recebia. Respondeu-me que o sangue dos kupen era fervido, o que os tornava mais fracos, os impedia de correr com as pesadas toras de madeira dos Timbira e os tornava piores caçadores. Mas, como eles tinham as suas próprias invenções, podiam viver bem sem atributos tão importantes para a vida dos Apanjekra e o faziam na cidade, a "aldeia dos brancos".

Entender o que está envolvido nas definições identitárias ligadas à indianidade e à não indianidade é vital para pensarmos as declarações de cor ou raça que não correspondem às expectativas dos analistas que inferem que a população indígena sempre se identificará como tal. Ao tratar dos dados Panará, outro povo Jê setentrional, Ewart (2014) indica que a noção de identidade, vinculada aos conceitos nativos de parentesco e humanidade, está associada à percepção de um fundo comum de intersubjetividade. A capacidade das pessoas de se entenderem implica o reconhecimento das necessidades mútuas. É na atenção a essas necessidades, expressa na corresidência, na comensalidade e nas dádivas, que o parentesco toma lugar: eu reconheço o que outro precisa, e isto se torna parte de mim. O compartilhamento (Widlock, 2013; Woodburn, 1998) é a forma assumida pelas relações identitárias entre os Apanjekra (Guimarães, 2017), pois, através do compartilhamento, toma-se parte na existência de outras pessoas, evocando a "mutualidade do ser" característica do parentesco (Sahlins, 2013).

Da mesma maneira que os parentes que não distribuem os bens obtidos em suas residências são vistos como parentes ruins, os Apanjekra que têm acesso a maior volume de recursos dos kupen, mas não os compartilham com a aldeia, são acusados de estarem se tornando "brancos". Este juízo é feito sobre lideranças, professores ou agentes de saúde que, apesar de terem maiores rendimentos e trânsito nas zonas urbanas, são criticados por não contribuírem o suficiente para as atividades na aldeia. Isto não significa apenas que sejam sovinas: se eles não 
estão distribuindo seus bens com os mehin, o devem estar fazendo com os kupen. Empregar os recursos disponíveis na cidade, passar longos períodos longe de suas famílias, aprender a atuar no universo não indígena, a falar, escrever, lidar com o dinheiro e outras tecnologias estrangeiras indicam que estas pessoas estão se assemelhando aos "brancos". Essa seria, portanto, outra forma de pensar os critérios nativos para responder à pergunta sobre cor ou raça no Censo.

As suposições aqui levantadas não são exclusivas. Não apenas é possível que mais de uma delas tenha influenciado os resultados do Censo 2010, como é provável que outros fatores também tenham contribuído para os dados obtidos. Ademais, as três hipóteses indicadas se complementam: a definição da identidade indígena se pautar por capacidades, transformações corporais e intersubjetividade (hipótese 3 ) indica como a cor de pele não está no mesmo registro da indianidade (hipótese 1), e a animosidade do contexto local influencia como essas definições serão expressas (hipótese 2). Ainda assim, o exercício é especulativo: sem o acompanhamento direto do trabalho dos recenseadores ou entrevista posterior com os respondentes do Censo, não é possível definir os fatores que levaram aos números registrados pelo IBGE. Isto porque as hipóteses levantadas dependem de um equívoco na comunicação (e na intenção) entre o entrevistador e o entrevistado. É possível que o entrevistado não compreenda plenamente os objetivos da investigação censitária ou, então, busque revertêlos, como em uma não declaração intencional de sua identidade. Além disso, cada uma das três hipóteses permite objeções. No contexto das relações mehin - kupen, os Apanjekra sabem que são vistos pelo Estado como indígenas e não como brancos, pretos, pardos ou amarelos. Reconhecendo essa situação, poderiam contornar os mal-entendidos da questão sobre cor e raça que sustentam a primeira e a terceira hipótese. Sobre esta última, que trata da possibilidade de se tornar kupen, é preciso considerar que tal ideia surge em situações pejorativas, em que alguém é acusado de se assemelhar aos kupen em razão de um comportamento sovina. Ou seja, dificilmente seria captada por uma metodologia pautada pela autodeclaração. Por fim, a segunda hipótese, que trata do contexto conflituoso da TI, poderia levar os Apanjekra a reafirmarem sua indianidade em virtude da luta pela terra, aumentando ao invés de diminuir a quantidade de indígenas na TI.

Esse quadro nos leva a uma quarta hipótese para os dados do Censo 2010: a de que muitos dos invasores da TI se consideraram indígenas, após terem se declarado "brancos", "pretos", "amarelos" ou "pardos". Dado que o Censo foi realizado em meio a uma disputa territorial pautada pela identidade indígena, os ocupantes da área ampliada podem ter indicado que também eram indígenas para não serem removidos da TI. Esta ideia remete ao meu encontro com um morador da área ampliada, já descrito anteriormente, em que ele tentou dissipar as diferenças identitárias entre os não indígenas e os indígenas. Em minhas viagens pelo 
território Apanjekra, esse comportamento era constante: ocupantes kupen mencionavam que estavam naquela terra há décadas, que tinham uma história comum com os indígenas, que já tinham participado de rituais na aldeia e alguns, inclusive, teriam sido "batizados" pelos indígenas, sentindo-se parte também das populações originárias daquele território. Essas são as pessoas que vivem nos povoados atravessados pelos Apanjekra em suas idas mensais à cidade para sacar benefícios sociais como o Programa Bolsa Família ou a aposentadoria rural. Sobre tais pessoas não fiz qualquer levantamento populacional.

Observando os dados, o primeiro conjunto de hipóteses precisa ser combinado com essa nova ideia. Na TI Porquinhos, o número de pessoas autodeclaradas Apanjekra registrado pelo Censo 2010 é inferior ao número de indígenas na aldeia em meus levantamentos populacionais. As hipóteses 1 a 3 oferecem possíveis entendimentos para esta sub-representação, pois colocam sentidos nativos para outras declarações de cor ou raça. Em contrapartida, o número total de pessoas que se declararam ou consideraram indígenas, na área ampliada da TI Porquinhos, é bem superior aos registros etnográficos, fortalecendo a hipótese 4. Esta hipótese é, de certo modo, uma inversão da hipótese 2: em vez de os Apanjekra esconderem sua identidade em um contexto violento, posseiros do entorno da aldeia assumem a identidade indígena por conta da disputa fundiária pautada pela identidade étnica. Para seguir essa ideia, é necessário investigar outros dados da TI Porquinhos.

\section{Entornos censitários}

Até o momento, empreguei o conhecimento etnográfico sobre a TI Porquinhos para refletirmos sobre os dados censitários. Observamos o Censo 2010 a partir da aldeia, lendo seus resultados como um retrato tirado em um contexto específico e pouco trivial. Considerando os sentidos que a população estudada confere ao universo em que vive, formulamos hipóteses para compreendermos os números observados. Esta é uma forma de a etnografia auxiliar a interpretação dos dados demográficos. Para aprofundar esta investigação, irei agora utilizar os dados censitários para lançar luz sobre o contexto local.

Se a observação de campo conferiu uma nova dimensão às estatísticas oficiais consideradas, permitindo relativizá-las e concebê-las como fruto de interações particulares em um momento específico, elas nos dizem pouco sobre muitas das pessoas captadas nos dados da TI Porquinhos. Isto porque a investigação etnográfica não foi realizada com todos os 2.600 indivíduos registradas pelo Censo 2010: mantive contato próximo apenas com os cerca de 700 habitantes da aldeia Porquinhos. Considerar outras variáveis junto ao quesito "cor ou raça" nos auxilia a distinguir e caracterizar o restante da população. Os dados demográficos oferecem 
uma via para o etnógrafo refletir também sobre as populações próximas à estudada por ele. A observação dos dados sobre os domicílios como o tipo de domicílio ${ }^{9}$ e a situação do setor da coleta poderia ser um caminho inicial para divisar perfis sociais distintos. Contudo, todos os domicílios visitados foram registrados como "casa", e essas 499 casas estão em "área rural exclusive aglomerado rural". Portanto, não é possível associar diferenças nos tipos de residência com padrões populacionais. Uma caracterização mais precisa é obtida ao observarmos as informações sobre o abastecimento de água nos domicílios (Tabela 2).

Tabela 2 - Frequências de pessoas segundo declaração de cor ou raça (indígena e não indígena) residentes em domicílio de acordo com a forma de abastecimento de água - TI Porquinhos (MA). Censo Demográfico 2010

\begin{tabular}{l|l|r|r}
\hline $\begin{array}{l}\text { Indígena } \\
\text { (cor ou raça) }\end{array}$ & Forma de abastecimento de água & Frequência & $\%$ \\
\hline \multirow{4}{*}{ Sim } & Poço ou nascente na propriedade & 3 & $0,7 \%$ \\
\cline { 2 - 4 } & Rios, açudes, lagos e igarapés & 6 & $1,0 \%$ \\
\cline { 2 - 4 } & Poço ou nascente na aldeia (indígena) & 577 & $98,3 \%$ \\
\cline { 2 - 4 } & Total & 587 & $100,0 \%$ \\
\hline \multirow{4}{*}{ Não } & Poço ou nascente na propriedade & 528 & $26,1 \%$ \\
\cline { 2 - 4 } & Poço ou nascente fora da propriedade & 482 & $23,9 \%$ \\
\cline { 2 - 4 } & Rios, açudes, lagos e igarapés & 1.008 & $50,0 \%$ \\
\cline { 2 - 4 } & Total & 2.018 & $100,0 \%$ \\
\hline
\end{tabular}

Fonte: elaborado pelo autor com base em dados do IBGE, disponíveis no Banco Multidimensional de Estatísticas.

Uma vez que o Censo 2010 inclui uma variável específica de resposta sobre saneamento para a população residente em TI (IBGE, 2012b), os resultados para esta variável podem ser indiretamente interpretados visando a identificar a ocupação territorial da TI.

Os dados sobre abastecimento de água na TI Porquinhos são reveladores: apenas aqueles que se declararam indígenas eram abastecidos por "poço ou nascente na aldeia (indígena)", sendo essa forma de abastecimento correspondente a 577 indivíduos (98,3\% dos 586 autodeclarados indígenas). Para pensarmos quem são os habitantes da aldeia Porquinhos, a análise das respostas quanto ao acesso aos recursos hídricos pode gerar interpretações mais diretas do que as intricadas suposições levantadas para o quesito "cor ou raça". ${ }^{10}$ Isto porque sabemos, após período de observação etnográfica, que os Apanjekra vivem todos na mesma aldeia, ao passo que os posseiros estão dispersos pelo território, ao redor das estradas que levam para as áreas urbanas de Barra do Corda e de Fernando Falcão.

Uma primeira conclusão é que, no caso de Porquinhos, as pessoas que os Apanjekra reconheceriam como indígenas coincidem com aquelas que se declararam 
indígenas no quesito "cor ou raça" e indicaram pertencimento étnico. Isso nos permitiria excluir a questão de cobertura de nossas considerações sobre os Apanjekra, levantando um ponto importante para o trabalho do pesquisador interessado em compreender as relações interétnicas locais, qual seja, o fato de grande parte da população localmente não considerada indígena pelos ocupantes tradicionais da TI se apresentar como indígena para o Estado na questão de cobertura. Além dessa pista para um exame aprofundado do investigador de campo sobre as dinâmicas identitárias locais e sua expressão na relação com os órgãos oficiais, a observação de outros dados pode indicar as complexidades dos entornos da aldeia. Isto pode ser visto nas informações sobre alfabetização e renda ${ }^{11}$ de acordo com o quesito "cor ou raça" (Tabela 3).

Tabela 3 - Taxas de alfabetização e renda média - TI Porquinhos (MA). Censo Demográfico 2010

\begin{tabular}{l|c|c|c}
\hline \multirow{2}{*}{ Alfabetização } & \multicolumn{3}{|c}{ Segmento populacional } \\
\cline { 2 - 4 } & Cor ou raça (indígena) & Se considera indígena & Não indígena \\
\hline Sim & $61,3 \%(\mathrm{n}=302)$ & $69,8 \%(\mathrm{n}=716)$ & $57,5 \%(\mathrm{n}=399)$ \\
\hline Não & $38,7 \%(\mathrm{n}=191)$ & $30,28 \%(\mathrm{n}=310)$ & $42,5 \%(\mathrm{n}=295)$ \\
\hline $\begin{array}{l}\text { Renda média } \\
(\mathrm{R} \$)\end{array}$ & 66,5 & 109,8 & 74,0 \\
\hline
\end{tabular}

Fonte: elaborado pelo autor com base em dados do IBGE, disponíveis no Banco Multidimensional de Estatísticas.

Dentre as opções de declaração em "raça ou cor", os indígenas apresentam maior percentual de analfabetos no Maranhão12 (e no Brasil), mas, na TI Porquinhos, o segmento com maior índice de analfabetismo inclui aqueles que não se declararam nem se consideraram indígenas. Chama a atenção que a renda da população que não se declarou ou considerou indígena é muito mais próxima à renda dos declarados indígenas; esses dois segmentos populacionais apresentam uma renda muito inferior à do segmento que se considerou indígena, também contrariando os indicadores estaduais e nacionais, nos quais quem não se identifica como indígena em nenhuma questão apresenta o maior rendimento.

Ao destacarmos o "enigma Porquinhos" no Censo 2010, apontei para a necessidade de considerar contextos locais na captação dos dados, em especial em regiões de conflito marcadas pelo preconceito e diferentes formas de violência associadas à disputa por espaço. Um dado importante é que, após a Funai definir a ampliação da TI Porquinhos, o Instituto Nacional de Colonização e Reforma Agrária (Incra) maranhense assentou no território indígena algumas famílias de lavradores sem-terra. A hipótese que levanto, tentando entender o maior analfabetismo e menor renda entre as pessoas que não se declararam ou consideraram indígenas, é a de que esses indivíduos correspondem aos assentados (que, atualmente, já não 
vivem mais naquela região). Sem acesso garantido à terra e frequentemente em movimento, seu rendimento financeiro e acesso à educação formal seriam prejudicados em comparação com os demais ocupantes da região. Como eram pessoas recém-chegadas àquele território, com uma identidade social já definida por seu movimento político, estariam talvez menos envolvidos nas disputas identitárias em curso que, como indiquei anteriormente, podem ter levado uma grande parcela dos invasores a se considerarem indígenas na questão de cobertura, por receio de serem desalojados de suas habitações. Ao contrário dos invasores e posseiros que habitam a TI há anos, os assentados não participam das redes de relações dos indígenas nem mantêm com eles os contatos já descritos. Mesmo que não se possa chegar a conclusões definitivas, os dados permitem ao investigador criar hipóteses sobre os entornos da população que ele conhece em primeira mão - voltar a campo e estudar suas dinâmicas demográficas é vital para poder validá-las.

\section{Para onde foi a população?}

Há, ainda, um último ponto que merece destaque em nossa investigação. Se estabelecemos que aos Canela Apanjekra correspondam os 583 indivíduos que se declararam indígenas e que indicaram esse pertencimento étnico, há uma grande disparidade entre o registro do Censo 2010 e meus levantamentos populacionais. Em 2012, registrei 690 pessoas, número que acredito ter subestimado a quantidade de habitantes da aldeia. Para onde foi o contingente de indivíduos que não está no Censo 2010, ou seja, algo em torno de uma centena de pessoas?

Como temos uma correspondência entre as declarações de indígena em "cor ou raça", de etnia e os dados sobre o abastecimento de água da aldeia, é razoável supor que os Apanjekra se declararam indígenas, etnia Kanela, e a eles não correspondem os indivíduos que "se consideraram" indígenas na questão de cobertura, que apresentam perfis de renda e alfabetização bem distintos. Isso nos leva a duas hipóteses. A primeira, a de que essas mais de 100 pessoas não foram recenseadas. Por algum motivo, elas não chegaram a responder ao questionário. A principal razão para tal seria pelo fato de não estarem na aldeia no período em que o recenseador visitou Porquinhos. Como os cultivares indígenas se dividem entre os das hortas contíguas às casas e os das roças, a quilômetros de distância da aldeia, uma possibilidade é que parte da população estivesse dispersa pela TI, cuidando de sua produção agrícola. As famílias viajam conjuntamente, deixando as habitações aldeãs vazias, podendo permanecer nas roças por várias semanas muitas são de difícil acesso, complicando as tentativas do recenseador de as alcançar. O problema desta hipótese é que, no meio do ano, quando o recenseador está em campo aplicando os questionários, as visitas aos roçados são menos frequentes e, por não ser período de plantio, a permanência fora da aldeia é mais curta. 
A segunda hipótese retorna à mobilidade indígena, centrada no deslocamento entre aldeia e cidade. Além das saídas da aldeia para os roçados, os Apanjekra viajam, todos os meses, para as zonas urbanas mais próximas. O principal destino é Barra do Corda, maior cidade da mesorregião central maranhense, para onde as picapes dos patrões dos benefícios sociais se dirigem (Brasil, 2016). A permanência na cidade é incerta e, por vezes, pode durar algumas semanas. Resta saber se, em Barra do Corda, essas pessoas foram captadas pelo Censo, visto que estavam em trânsito e o domicílio de referência delas estaria na aldeia. Quando estão na cidade, as famílias costumam se hospedar em uma ampla construção ocupada apenas pelos indígenas em trânsito, que não tem numeração nem dispõe de abastecimento de água pela rede pública (que compram ou pegam dos rios Corda e Mearim, que cortam o espaço urbano). Exceções correspondem àqueles que vão a Barra do Corda para tratamento médico e se hospedam temporariamente em salas e corredores da sede administrativa do polo de saúde indígena.

Os dados do IBGE nos informam que, das 40 pessoas que se declararam Kanela em Barra do Corda, 34 o fizeram em setores censitários em situação urbana (Tabela 4). Porém, não há uniformidade na qualificação dos domicílios urbanos em que estavam: 26 viviam em habitações com abastecimento de água (ao contrário do barracão ocupado pela maioria das famílias) e 20 em domicílios com fossas rudimentares para o esgotamento sanitário, em consonância com o que se verifica no barracão. Esse terreno é ocupado apenas pelos Canela Apanjekra, mas os Canela Ramkokamekra também passam períodos em Barra do Corda e poderiam ter se declarado Kanela na etnia, como ocorreu na TI Kanela, habitada por eles. Assim, os dados censitários da área urbana de Barra do Corda não nos permitem realizar muitas inferências sobre a presença Apanjekra na cidade, que hoje é parte do cotidiano deles e de diversos outros povos indígenas no Brasil. Portanto, também não possibilitam definir quantos indígenas não foram captados por estarem em suas roças, com os domicílios vazios.

Tabela 4 - Frequências de pessoas das etnias Kanela e Kanela Rankokamekra residentes em domicílios urbanos segundo características de saneamento - município de Barra do Corda (MA). Censo Demográfico 2010

\begin{tabular}{l|c|c}
\hline \multirow{2}{*}{ Variáveis } & \multicolumn{2}{|c}{ Declaração de etnia } \\
\cline { 2 - 3 } & Kanela & Kanela Rankokamekra \\
\hline Total de indivíduos & 34 & $\mathrm{x}$ \\
\hline Abastecimento de água & 26 & $\mathrm{x}$ \\
\hline Rede geral de distribuição & 7 & - \\
\hline Poço ou nascente fora da propriedade & $\mathrm{x}$ & - \\
\hline Rios, açudes, lagos e igarapés & $\mathrm{x}$ & - \\
\hline Outra & & \\
\hline
\end{tabular}


Tabela 4 - Frequências de pessoas das etnias Kanela e Kanela Rankokamekra residentes em domicílios urbanos segundo características de saneamento - município de Barra do Corda (MA). Censo Demográfico 2010 (cont.)

\begin{tabular}{l|r|r}
\hline \multirow{2}{*}{ Variáveis } & \multicolumn{2}{|c}{ Declaração de etnia } \\
\cline { 2 - 3 } & Kanela & Kanela Rankokamekra \\
\hline Esgotamento & 6 & - \\
\hline Fossa séptica & 20 & $\mathrm{x}$ \\
\hline Fossa rudimentar & $\mathrm{x}$ & - \\
\hline Vala & $\mathrm{x}$ & $\mathrm{x}$ \\
\hline Outro & $\mathrm{x}$ & - \\
\hline Não aplicável & & \multicolumn{2}{|c}{} \\
\hline
\end{tabular}

Fonte: elaborado pelo autor com base em dados do IBGE, disponíveis no Banco Multidimensional de Estatísticas.

\section{Quem está no Censo?}

Apesar de diversos avanços do Censo na captação de dados para indígenas, é possível que, em razão de deslocamentos variados e de habitações não presentes nas bases territoriais do IBGE e da Funai, parte da população não seja recenseada. A invisibilidade estatística de povos tradicionais é um entrave para a implementação de políticas diferenciadas que tem essas populações como alvo, comprometendo a efetivação de direitos para esse segmento da sociedade. Se parte da população da aldeia Porquinhos desapareceu do Censo 2010, é possível afirmar, também, que os dados demográficos não estiveram presentes lá: os Apanjekra não têm conhecimento real das estatísticas populacionais produzidas sobre eles próprios, seus usos e suas implicações. Aprimorar o questionário censitário e a cobertura da base territorial foi um primeiro passo para a produção de melhores informações sobre os indígenas. Um passo seguinte é a inclusão deles nas diferentes etapas da investigação: consulta pré-censo; participação de recenseadores indígenas em TIs; discussão dos dados e das formas mais eficientes de divulgação, tanto para os próprios indígenas como para o restante da sociedade.

O Censo Demográfico busca captar alguns fenômenos e informações centrais para a sociedade brasileira (como trabalho, rendimento e migração), porém não dá conta de fenômenos determinantes nas dinâmicas populacionais de povos culturalmente diferenciados (Campos $G$ Estanislau, 2016). A grande questão, porém, não está em não captar fenômenos específicos, como os deslocamentos entre aldeia e cidade, e as formas particulares dos indígenas de ocuparem o espaço urbano. O desafio está no fato de que a existência desses fenômenos contribui para acentuar 
a invisibilidade das populações indígenas em estatísticas oficiais. A solução é incluir os indígenas na construção do Censo, pensando em como contornar os desafios de adequação dos questionários e abordagem a partir de adaptações metodológicas.

No caso de Porquinhos e dos Apanjekra, a atuação de recenseadores, guias ou intérpretes indígenas contribuiria para que os indígenas em roçados de difícil acesso, mas conhecidos pela comunidade, não fossem ignorados. Também é possível supor que a resposta para "etnia" seria mais precisa, dado que, se os Apanjekra se identificam apenas como Canela diante dos não indígenas, entre si eles especificam serem Canela Apanjekra. Isso permitiria diferenciar os Canela Apanjekra dos Canela Ramkokamekra, auxiliando na identificação étnica em contextos urbanos e no estudo dos fluxos populacionais advindos de diferentes aldeias e TIs.

Nenhum desses pequenos e significativos avanços se baseia na suposição de que os indígenas seriam melhores demógrafos ou antropólogos de suas próprias comunidades se comparados com não indígenas. Assim como ocorre com as etnografias (Strathern, 2014), os modos de investigação dos censos demográficos e suas categorias não apresentam equivalentes diretos nas formas de produção do conhecimento nativo. Nos últimos anos, demógrafos e intelectuais indígenas chamaram atenção para essa diferença, expressa em conceitos como "tempo", "mobilidade" e "raça" (Rifkin, 2017; Standfield, 2018; Tallbear, 2013). Tentei contribuir para esta discussão demonstrando a complexidade envolvida na análise das questões identitárias para a TI Porquinhos no Censo 2010. Compreendendo que o universo vivido indígena pode não ser adequadamente expresso pelos conceitos tradicionalmente usados para descrever as dinâmicas populacionais, é preciso observar os contextos locais e os conceitos empregados pelos respondentes dos questionários para pensar sobre sua própria condição.

É justamente no encontro do conhecimento acadêmico com o pensamento indígena que novas formas de se conhecer as populações indígenas podem surgir. Incorporar esses entendimentos nativos e suas formas de investigação na pesquisa demográfica seria uma forma de fortalecer a "soberania de dados indígenas" (Kukutai G Taylor, 2016) no contexto brasileiro. O censo demográfico enfrenta o desafio de ser aplicado à totalidade dos domicílios do país. Chegar a esses endereços é um primeiro passo. O segundo é apresentar questões adequadas a todas as moradias. No caso dos indígenas, esses passos podem ser dados com adaptações metodológicas e a colaboração deles próprios na coleta de dados. Mesmo que ainda estejamos distantes de pesquisas demográficas oficiais em que os indígenas sejam protagonistas, é preciso assumir que, sem a participação deles, a captação de dados ficará prejudicada, e a leitura dos dados de TIs pode ser mais complexa do que seria de se esperar. Não apenas fenômenos importantes para compreender as dinâmicas populacionais indígenas não serão conhecidos, como a invisibilidade estatística persistirá. Os censos continuarão a ser vistos apenas por aqueles que 
estão nos kupen krĩ, as "aldeias dos brancos", excluindo os indígenas dos dados e silenciando suas vozes nos debates.

* Agradeço ao CNPq, à Capes e à Faperj por terem financiado minha pesquisa doutoral e meu trabalho de campo entre 2011 e 2016. Este capítulo foi escrito como parte do projeto Saúde Indígena no Brasil: perspectivas históricas, socioculturais e políticas, apoiado pelo Wellcome Trust (financiamento n. 203486/Z/16/Z). Agradeço a Ricardo Ventura Santos pela leitura da primeira versão do texto e por suas importantes sugestões.

1 Esse número foi subestimado. Realizado em outubro, no período em que começa o trabalho mais intenso nas roças, o levantamento certamente não captou todos os habitantes que não estavam na aldeia nos dias de coleta de dados.

2 Os recenseadores registravam as respostas em um Personal digital assistant (PDA), um pequeno computador manual que continha o questionário e podia abrir novas questões a partir das respostas anteriores. Era equipado com GPS, de modo a identificar se o setor censitário em que o recenseador atuava era TI. O Censo 2010 foi o primeiro em que a base territorial do IBGE contou com os dados oficiais da Funai sobre territórios indígenas, considerando como TIs aquelas já homologadas ou declaradas, e excluindo aquelas em estágios anteriores de reconhecimento pelo Estado, como as identificadas ou em identificação (IBGE, 2012a).

3 O capítulo 8 desta coletânea, de Gerson L. Marinho, Ricardo V. Santos e Alessandra T. Simoni, apresenta uma análise dos resultados da pergunta "se considera" em escala nacional.

4 A portaria de criação do Grupo de Trabalho (GT) para a revisão dos limites da TI é de 30 de outubro de 2000. O relatório circunstanciado do GT, coordenado pelo antropólogo Jaime Siqueira, foi entregue à Funai em maio de 2003.

5 Essas informações estão disponíveis em: < https://censo2010.ibge.gov.br/terrasindigenas/>. Acesso em: 22 mar. 2018.

6 Kanela e timbira correspondem à língua timbira, falada pelos Apanjekra, Ramkokamekra, Gavião, Krahô e Krinkati. Guajajara e tenetehara também são nomes distintos dados à mesma língua, falada pelos Tenetehara.

7 Por conta do sigilo estatístico, frequência entre 1 e 5 é indicada por um " $\mathrm{x}$ " nos dados gerados a partir do Banco Multidimensional de Estatística (BME). Para permitir os cálculos sem desconsiderar esses valores, considerei-os como valendo 3, salvo quando era possível conhecer o valor correto em virtude das totalizações observadas nas saídas do BME. Agradeço a Ricardo Ventura Santos pelo auxílio no uso desses dados.

8 Em seu capítulo nesta coletânea, Gerson L. Marinho, Ricardo V. Santos e Alessandra T. Simoni apresentam argumento similar na discussão que desenvolvem sobre os resultados da pergunta "se considera". 
9 Dentre os 18 tipos de domicílio possíveis para o Censo 2010, está "oca ou maloca", descrito da seguinte forma: "quando localizado em habitação indígena, situada em terras indígenas, de características rústicas, podendo ser: simples e sem parede; pequena, feita com galhos de árvores e coberta de palha ou folhas; ou grande choça (cabana, casebre, palhoça, choupana) feita de taquaras e troncos, coberta de palmas secas ou palha, e utilizada como habitação por várias famílias indígenas" (IBGE, 2012b: 27).

10 Em outros contextos, é possível que outras variáveis, como o fornecimento de energia elétrica, sejam úteis aos investigadores para melhor compreender a população estudada. No caso de Porquinhos, onde há energia elétrica na aldeia e em boa parte dos povoados dentro da TI, analisar esse dado seria pouco esclarecedor.

11 A variável escolhida no BME foi "renda domiciliar per capita (operação: média)".

12 No Maranhão, o Censo 2010 registrou analfabetismo de 40,7\% para indígenas, 27,4\% para negros, 23,5\% para pardos, 22,3\% para amarelos e 17,4\% para brancos (dados do BME/IBGE). Inferior a 5 indivíduos, o número de declarados amarelos na TI Porquinhos não é significante.

\section{Referências}

AZANHA, G. A Forma Timbira: estrutura e resistência, 1984. Dissertação de Mestrado, São Paulo: Universidade de São Paulo.

AZEVEDO, M. Os povos indígenas e os censos demográficos no Brasil. In: BERCÓ, E. (Org.). Demografia na Unicamp: um olhar sobre a produção do Nepo. Campinas: Unicamp, 2017.

BRASIL. Lei n. 6.001 de 19 dez. 1973. Estatuto do Índio. Diário Oficial da União, Brasília, 1973.

BRASIL. Petição n. 3.388-4. Roraima. Ação Popular sobre Demarcação da TI Raposa Serra do Sol. Relator: Carlos Ayres Britto, 2008. Disponível em: < http://redir.stf.jus.br/paginadorpub/paginador.jsp?docTP=ACGdocID=630133>. Acesso em: 28 set. 2018 .

BRASIL. Recurso Ordinário em Mandado de Segurança n. 29.542. Contesta a ampliação dos limites da TI Porquinhos. Relatora: Carmen Lúcia, 2014. Disponível em < http://redir.stf. jus.br/paginadorpub/paginador.jsp?docTP $=\mathrm{TPGdocID}=7218303>$. Acesso em: 28 set. 2018.

BRASIL. Ministério do Desenvolvimento Social e Combate à Fome. Relatório Final: estudos etnográficos sobre o Programa Bolsa Família entre povos indígenas. Brasília: Ministério do Desenvolvimento Social e Combate à Fome, 2016.

CALDWELL, J. et al. Anthropology and demography: the mutual reinforcement of speculation and research. Current Anthropology, 28(1): 25-43, 1987.

CAMPOS, M. B. G ESTANISLAU, B. R. Demografia dos povos indígenas: os censos demográficos como ponto de vista. Revista Brasileira de Estudos de População, 33(2): 441-449, 2016. 
CARNEIRO DA CUNHA, M. Lógica do mito e da ação: o movimento messiânico Canela de 1963. In: CARNEIRO DA CUNHA, M. Cultura com Aspas e Outros Ensaios. São Paulo: Cosac Naify, 2009.

COELHO DE SOUZA, M. Nós, os vivos: "construção da pessoa" e "construção do parentesco" entre alguns grupos Jê. Revista Brasileira de Ciências Sociais, 16(46): 69-96, 2001.

COELHO DE SOUZA, M. Parentes de sangue: incesto, substância e relação no pensamento timbira. Mana, 10(1): 25-60, 2004.

CROCKER, W. The Canela (Eastern Timbira), I: an ethnographic introduction. Washington: Smithsonian Institution Press, 1990.

CROCKER, W. G CROCKER, J. Os Canela: parentesco, ritual e sexo em uma tribo da Chapada Maranhense. Rio de Janeiro: Museu do Índio, 2009.

EWART, E. Space and Society in Central Brazil: a Panará ethnography. New York: Bloomsbury Academic, 2014.

GUIMARÃES, B. N. Os Caminhos da Terra Indígena dos Canelas, 2012. Dissertação de Mestrado, Rio de Janeiro: Universidade Federal do Rio de Janeiro.

GUIMARÃES, B. N. O Outro Lado da Moeda: dos benefícios sociais dos brancos ao parentesco dos Apanjekra, 2017. Tese de Doutorado, Rio de Janeiro: Universidade Federal do Rio de Janeiro.

GUIMARÃES, B. N. G GUERRA, M. TI Porquinhos: o golpe da grilagem e do STF contra os Canela e a Constituição. In: RICARDO, B. G RICARDO, F. (Orgs.). Povos Indígenas no Brasil: 2011-2016. São Paulo: Instituto Socioambiental, 2017.

GREENE, M. G CROCKER, W. Some demographic aspects of the Canela indians of Brazil. South American Indian Studies, 4: 47-62, 1994.

INSTITUTO BRASILEIRO DE GEOGRAFIA E ESTATÍSTICA (IBGE). Censo Demográfico 2010: características gerais dos indígenas - resultados do universo. Rio de Janeiro: IBGE, $2012 \mathrm{a}$.

INSTITUTO BRASILEIRO DE GEOGRAFIA E ESTATÍSTICA (IBGE). Censo Demográfico 2010: famílias e domicílios - resultados da amostra. Rio de Janeiro: IBGE, 2012b.

KELLY, J. A. Notas para uma teoria do "virar branco". Mana, 11(1): 201-234, 2005.

KUKUTAI, T. G TAYLOR, J. Indigenous Data Sovereignty: towards an agenda. Acton: ANU Press, 2016.

LADEIRA, M. E. A Troca de Nomes e a Troca de Cônjuges: uma contribuição ao estudo do parentesco timbira, 1982. Dissertação de Mestrado, São Paulo: Universidade de São Paulo.

LAVE, J. Cycles and trends in Krinkati naming practices. In: MAYBURY-LEWIS, D. (Ed.). Dialectical Societies: the Gê and Bororo of Central Brazil. Cambridge: Harvard University Press, 1979. 
LOVEMAN, M. National Colors: racial classification and the state in Latin America. New York: Oxford University Press, 2014.

MATTA, R. Mito e antimito entre os Timbira. In: LARAIA, R. (Org.). Mito e Linguagem Social. Rio de Janeiro: Tempo Brasileiro, 1970.

MELATTI, J. C. Nominadores e genitores: um aspecto do dualismo Krahó. In: SCHADEN, E. (Org.). Leituras de Etnologia Brasileira. São Paulo: Companhia Editora Nacional, 1976.

PEREIRA, N. O. M. Innovations on measuring the census indigenous population in the 2010 Brazilian population. Statistical Journal of the IAOS, 33(2): 487-494, 2017.

RIFKIN, M. Beyond Settler Time: temporal sovereignty and indigenous self-determination. Durham, London: Duke University Press, 2017.

SAHLINS, M. D. What Kinship Is $\square$ and Is Not. Chicago: The University of Chicago Press, 2013.

SEEGER, A.; MATTA, R. G VIVEIROS DE CASTRO, E. B. A construção da pessoa nas sociedades indígenas brasileiras. In: OLIVEIRA FILHO, J. P. (Org.). Sociedades Indígenas e Indigenismo no Brasil. 1. ed. Rio de Janeiro: Universidade Federal do Rio de Janeiro, Marco Zero, 1987.

STANDFIELD, R. (Ed.). Indigenous Mobilities: across and beyond the antipodes. Acton: ANU Press, 2018.

STRATHERN, M. Os limites da autoantropologia. In: STRATHERN, M. O Efeito Etnográfico e Outros Ensaios. Trad. Iracema Dulley, Jamille Pinheiro Dias, Luísa Valentini. São Paulo: Cosac Naify, 2014.

TALLBEAR, K. Native American DNA: tribal belonging and the false promise of genetic science. Minneapolis: University of Minnesota Press, 2013.

THOMPSON, D. Schematic State: race, transnationalism and the politics of the census. Cambridge: Cambridge University Press, 2016.

VILAÇA, A. O que significa tornar-se Outro? Xamanismo e contato interétnico na Amazônia. Revista Brasileira de Ciências Sociais, v. 15, n. 44: 56-72, 2000.

WIDLOCK, T. Sharing: allowing others to take what is valued. HAU: Journal of Ethnographic Theory, 3(2): 11-31, 2013.

WOODBURN, J. Sharing is not a form of exchange: an analysis of property-sharing in immediate-return hunter-gatherer societies. In: HANN, C. (Ed.). Property Relation: renewing the anthropological tradition. Cambridge: Cambridge University Press, 1998. 


\section{Dinâmica Territorial e Mobilidade Espacial entre os Kaiowá e Guarani no Mato Grosso do Sul}

Este capítulo busca compreender as dinâmicas populacionais dos Guarani e Kaiowá em sua relação com o território, tratando dos deslocamentos realizados por indivíduos e suas famílias. As informações utilizadas foram obtidas a partir do Projeto Ojeguata Porã, que buscou captar as trajetórias pessoais nos fenômenos migratórios indígenas com uso de uma metodologia participativa, em que os próprios objetos da pesquisa eram sujeitos de sua realização, colaborando com adaptação e refinamento das questões e desenvolvendo a metodologia de coleta de dados. A qualificação dos fluxos populacionais dos Guarani e Kaiowá busca contribuir para o maior conhecimento demográfico sobre a complexa relação dos indígenas com o espaço.

A territorialidade guarani apresenta uma extensa área que inclui parte de quatro países latino-americanos: Brasil, Argentina, Paraguai e Bolívia, com uma população de mais de 280 mil pessoas, distribuídas em 1.416 comunidades, aldeias, bairros urbanos ou famílias, segundo dados do último Caderno Mapa Guarani Continental (EMGC, 2016). Os Guarani estão unidos por uma língua e uma cultura comuns e são um dos povos indígenas com maior presença territorial nas Américas. Eles mantêm uma comunicação entre si que demonstra a grande capacidade de vários povos Guarani para permanecerem Guarani, articulando suas demandas pelo reconhecimento de suas terras e sua autonomia como povos que vivem em países diferentes, mas unidos por laços de língua, visão de mundo, história e cultura.

A reconstrução simbólica de seu território, a partir de conhecimentos e práticas específicas, lhes permite expandir sua capacidade de compreensão de um mundo em transformação e encontrar e desenvolver novas perspectivas e práticas de atuação. Eles não são apenas testemunhas de tempos passados, mas protagonistas do presente e construtores do futuro. Seus caminhos de liberdade convidam a nos envolvermos em um movimento que não é exclusivamente deles, mas também de todos aqueles que não estão satisfeitos com o modelo econômico predatório que ameaça a terra e destrói a coexistência de tudo o que é humano com a natureza.

As ameaças para o futuro afetam os Guarani em decorrência da destruição ambiental maciça e da exclusão social e econômica generalizada. Fortalecendo os 
Guarani em sua luta por um espaço de vida e na defesa de seus direitos, estaremos fortalecendo nossa casa comum e nosso próprio futuro.

As reflexões que trazemos aqui são baseadas no conceito de território, elaborado por Benites (2014), a partir do relato de um Xamã de que a terra está sempre se expandindo:

A visão kaiowá e guarani sobre o mundo é produzida a partir da lógica espiritual tradicional. Quando afirmam que a terra está sempre se expandindo, estão se referindo à própria mobilidade tradicional (...) oguata (andar, caminhar, mover), que são maneiras de ocupar o espaço, de forma a não produzir fixação no mesmo lugar, condição dada pelo próprio deus. O surgimento da terra, pelo canto e a dança do Ñanderu, demonstra aos Kaiowá e Guarani a maneira própria de ocupação territorial. (Benites, 2014: 35)

A cosmologia guarani revela o modo de ser caminhante e sua mitologia é repleta desta indicação, como bem ilustra o mito das origens - ou mito do sol e da lua - em que os fatos da narrativa ocorrem durante uma longa caminhada.

Essa cosmologia também se revela na espiritualidade, como nas rezas: "Os cantos são meios para visualizar o caminho iluminado (tape rendy) que leva à morada dos deuses para adquirir conhecimento na condução do seu povo"; na gestação, "o corpo da mulher é como caminho por onde o ser passa do mundo espiritual para o mundo físico" (Benites, 2014: 35, 64). Brand (1997), em sua tese, também se refere aos caminhos percorridos pelos Guarani, como indicado no próprio título: O Impacto da Perda da Terra sobre a Tradição Kaiowá/Guarani: os difíceis caminhos da palavra.

O território, para os Guarani e Kaiowá, se caracteriza como espaço de comunicação, no qual a possibilidade do oguata, que quer dizer "caminhar", na língua guarani, é dimensão fundamental. Há inúmeros tipos de caminhadas ou formas de mobilidade espacial: para buscar atividades produtivas, como coleta de ervas e produtos específicos de um determinado lugar; para participar de atividades rituais, geralmente realizadas por muitas aldeias em conjunto. Oguata pode se traduzir, também, na visita a um parente, que pode durar semanas ou até anos; ou em uma "caminhada" em busca de trabalho e de novas experiências e conhecimento, característica dos deslocamentos dos jovens. O caminhar faz parte do universo cultural desses povos (Melià, 1989; Pissolato, 2007; Pereira, 2007).

\section{Deslocamentos espaciais dos povos indígenas na América Latina}

Os estudos da demografia na América Latina baseiam-se no livro Migraciones Indígenas en las Américas, do Instituto Interamericano de Derechos Humanos 
(IIDH, 2007). Essa publicação é considerada um subsídio importante para o conhecimento e análise das migrações indígenas. É produto de um evento realizado em 2006, com especialistas de várias temáticas e provenientes de diferentes países, e teve como principal objetivo reunir elementos que permitam melhorar as ações de proteção das pessoas que se deslocam na nossa região em busca de melhores condições de vida para elas e suas famílias. Este material visa a colaborar também no fortalecimento de políticas públicas que "promovam o desenvolvimento econômico e social destes povos, evitando desta maneira o deslocamento de muitas pessoas indígenas com as graves consequências que provocam seu desenraizamento das comunidades e a nível nacional" (IIDH, 2007: 8).

No contexto que vivenciamos na América Latina durante as últimas duas décadas do século $\mathrm{XX}$, a partir da consolidação das economias de mercado e das profundas transformações estruturais dos Estados, observa-se que as terras indígenas são afetadas pelo crescente avanço de projetos de desenvolvimento, como represas, grandes vias, pontes, extração mineral, exploração madeireira de grande escala e extração de petróleo, entre outros, que produziram invasões e despejos (Del Popolo G Ribotta, 2011). Relacionado a esse fato, constata-se ainda que a deterioração ambiental de suas terras, a pobreza, a falta de água e a pressão demográfica constituem os diversos fatores que estão provocando deslocamentos espaciais.

Nas últimas décadas, ocorre uma mudança significativa no que diz respeito à dinâmica populacional indígena e surge a crescente urbanização da população como um dos fatores mais importantes dos deslocamentos espaciais (Echeverri, 2012). No entanto, mesmo nas cidades, os Kaiowá e Guarani mantêm as redes de conexão com suas comunidades de origem e com sua família extensa. Mas a situação dos índios urbanos é um fenômeno novo e precisa de maiores estudos.

Em geral parte-se do pressuposto de que os povos indígenas, inclusive os jovens, "são eminentemente rurais, ideia associada à residência em territórios ancestrais. Assim mesmo, a crescente urbanização e as migrações campo-cidade também os alcançaram" (Del Popolo G Ribotta, 2011: 109). Segundo os autores, os Censos de 2000 revelaram que, "na região, por volta de $44 \%$ dos jovens indígenas residem em zona urbana, situação que chega a cerca de $80 \%$ no caso dos não indígenas do mesmo grupo etário (15 a 29 anos)". A presença significativa dos jovens já dá um indicativo para o motivo de eles migrarem para os centros urbanos.

No que diz respeito às razões da migração dos jovens, Del Popolo e Ribotta (2011) destacam a pobreza e a necessidade de buscar trabalho: "A pobreza nos territórios indígenas aparece como um dos principais fatores estruturais que causam a migração". Para os autores, é forte a necessidade de migrar "para buscar emprego para a subsistência familiar". Assim, "mesmo quando acessam às mais baixas remunerações, produto das menores oportunidades de emprego qualificado associado a uma baixa escolaridade", os autores avaliam que "a migração constitui 
uma importante estratégia para a sobrevivência dos povos indígenas" (Del Popolo G Ribotta, 2011: 113).

Com relação a este aspecto de sobrevivência dos povos indígenas, destacamos a fuga de conflitos nas reservas superpopulosas. Como exemplo, podemos citar Jarara e Takuara, que são terras indígenas (TIs) retomadas recentemente e que foram formadas por grupos familiares oriundos da reserva de Te'yikue, Caarapó, Mato Grosso do Sul (Colman, 2015).

Estanislau (2014) apresentou um panorama da migração indígena no Brasil a partir de construção de matrizes migratórias, utilizando-se dos microdados dos Censos Demográficos de 2000 e 2010. O Norte apresenta "um grande fluxo intrarregional com 18.551 não naturais que se deslocaram para essa mesma região, tendo como segundo maior destino, em 2000, a região Sudeste seguida da Centro-Oeste" (Estanislau, 2014: 51).

Em 2010, o Centro-Oeste se apresenta como principal destino fora da região Norte, com 2.795 pessoas, seguido pelo Sudeste. Os emigrantes originários da região Norte passam, de 2000 para 2010, de 26.813 para 30.097 pessoas, sendo que o maior número de pessoas que imigraram para a região Norte veio do Nordeste, seguido, em 2000, da região Sudeste e, em 2010, da Centro-Oeste (Estanislau, 2014).

Ainda segundo Estanislau, a maior parte dos movimentos migratórios indígenas na região Nordeste também acontece dentro da própria grande região, tendo como maior região de destino e de origem a Sudeste, nos anos de 2000 e 2010. A autora conclui "que existe um fluxo migratório entre Sudeste e Nordeste; e é possível dizer que provavelmente houve uma migração de retorno para o Nordeste na última década" (Estanislau, 2014: 36).

A região Sul chama atenção porque apresenta o maior número de movimentos migratórios dentro da mesma região, tendo como segundo maior destino o Sudeste em 2000 e 2010. "Dentre as pessoas que imigraram para a região Sul, 2.511 vieram do Sudeste em 2000 e 1.436 em 2010, sendo essa a região de origem com maior número de imigrantes no Sul" (Estanislau, 2014: 36). Para a autora,

O Centro-Oeste foi a única região em que houve um aumento de emigrantes, de 21.530 pessoas em 2000 para 22.609 em 2010. Em termos de imigrantes houve uma redução, de 29.554 em 2000 para 27.435 em 2010. Tanto em 2000 quanto em 2010, seu maior número de imigrantes é proveniente da própria, seguido da Nordeste. Em termos de destino, os emigrantes da região Centro-Oeste preferiram a própria região, seguida da região Sudeste. (Estanislau, 2014: 36)

No documento do IV Fórum Permanente para as questões indígenas da ONU, afirma-se que os povos indígenas reivindicam o direito de migrar e de não migrar: 
Reafirmamos a tradição ancestral dos povos indígenas de seu exercício de direito à livre mobilidade e seu reconhecimento na atualidade, e também seu direito a permanecer em seus territórios tradicionais e a não serem deslocados como resultado de uma imposição política econômica, conflitos armados e outros fenômenos que lesionam os direitos humanos coletivos e individuais. (EMGC: 8 - tradução livre das autoras)

Entre os Kaiowá e Guarani, o Estado tentou impor a imobilidade espacial da reserva, mas eles sempre encontram formas de sair em busca de novas alternativas, como têm sido as retomadas de áreas consideradas tradicionais pelos Kaiowá e Guarani (Brand, 1997; Colman, 2007) ou mesmo a opção por viver em áreas urbanas. Desta forma, o processo de confinamento não se conclui.

\section{Projeto Ojeguata Porã}

A realização do Projeto Ojeguata Porã sobre mobilidade espacial Guarani e Kaiowá se deu na TI Te'yikue, localizada no município de Caarapó, Mato Grosso do Sul. Implementado em 2008 e 2009, pretendia compreender melhor a mobilidade espacial dos Guarani nas regiões fronteiriças entre Paraguai, Argentina e Brasil (nos estados do RS, SC, PR e MS). Além disso, buscou aprimorar os dados disponíveis sobre demografia guarani. O projeto também tinha como objetivo construir uma tipologia de deslocamentos espaciais, incluindo aspectos temporais e intergeracionais, e constituir um banco de dados inicial sobre população que fosse de utilidade para pesquisadores, em geral, e para as comunidades guarani e kaiowá, especificamente (Colman et al., 2010). Esta pesquisa-piloto participativa foi implementada no âmbito do Projeto de Apoio ao Fortalecimento das Políticas Públicas entre os Guarani na Região Transfronteiriça: Brasil, Paraguai e Argentina, e foi realizada por professores e pesquisadores do Núcleo de Estudos e Pesquisas das Populações Indígenas/ Universidade Católica Dom Bosco e do Núcleo de Estudos de População/ Universidade Estadual de Campinas (Nepo/Unicamp), professores e lideranças guarani e kaiowá da Escola Ñandejára Polo da TI Caarapó (Colman et al., 2010).

É necessário conhecer os dados sobre população e compreender suas trajetórias migratórias, pois estes aspectos são primordiais para implementação das políticas públicas de saúde, educação, alternativas econômicas, entre outras (Colman et al., 2010). É cada vez mais importante, e é demanda claramente formulada, que a própria população indígena, em especial as suas lideranças, professores e agentes de saúde, "conheça e saiba manejar essas informações, condição para melhor fiscalizarem e participarem na implementação e controle social das políticas públicas a eles destinadas" (Colman et al., 2010: 4). 
Os princípios que orientam essas iniciativas são "investigar e, ao mesmo tempo, com os resultados concretos que vão sendo gerados, incorporar outras e novas questões a serem investigadas, sempre tendo como referência a participação do conjunto da comunidade" (Colman et al., 2010: 4). Nesse sentido, "o processo de investigação constitui-se, também, em importante processo de tomada de posição da própria comunidade local frente aos problemas em questão" (Colman et al., 2010: 4).

\section{Metodologia do Projeto Ojeguata Porã}

O projeto se desenvolveu a partir de várias reuniões e oficinas em que o tema foi discutido com professores, coordenadores e lideranças indígenas de Caarapó, no segundo semestre de 2008. "Na primeira oficina, o tema genérico 'mobilidade espacial' foi recortado para pensar no questionário e nas preocupações mais diretas da comunidade local" (Colman et al., 2010: 4).

O fato de conhecer outras experiências e a construção coletiva do instrumento de pesquisa - o questionário - foi importante, pois permitiu errar menos. "Partimos de alguns questionários já elaborados no âmbito de outras pesquisas participativas, incluindo questionários sobre pesquisas de trajetórias migratórias. Dessa forma, foi-se constituindo um questionário próprio para essa investigação" (Colman et al., 2010: 4).

Ao longo do processo, as pessoas foram sendo motivadas e envolvidas no projeto, como se pode perceber no detalhamento dos autores:

Após essa primeira oficina, os professores e lideranças locais conversaram e animaram alunos indígenas do Ensino Médio a participarem como pesquisadores deste trabalho. Foram realizados alguns ajustes no questionário e discutida a possibilidade de as entrevistas abrangerem todos os domicílios da Terra Indígena ou restringirem-se a uma amostragem. Nessa fase do trabalho, sabíamos que seria muito difícil conseguirmos visitar os cerca de 1.000 domicílios/casas existentes no âmbito de toda a Terra Indígena de Caarapó. (Colman et al., 2010: 4)

É interessante, na descrição apresentada, a maneira como foi construída a metodologia participativa, de conversa em conversa, do jeito dos Guarani. Dessa forma também se deu o envolvimento gradativo dos pesquisadores com o projeto. Uma segunda oficina, em março de 2009, permitiu a realização de pré-testes por parte de cada entrevistador, visitando pelo menos um domicílio.

Na etapa do pré-teste, foi formada uma pequena equipe responsável pela revisão e correção dos questionários, cuidados durante o trabalho de campo e coordenação do recebimento das fichas respondidas, acompanhando o número de casas/domicílios cobertos por região. Nessa etapa, foram realizados muitos ajustes e decidiu-se que as entrevistas seriam feitas por amostragem de domicílios, tentando cobrir pelo menos $40 \%$ das casas/domicílios de cada região da TI. Foi importante, 
ainda, discutir os principais conceitos presentes na pesquisa de domicílio, família, entre outros, escritos e acordados entre todos.

A ampla participação indígena deve ser entendida como um dos resultados mais importantes, embora não previsto inicialmente no projeto, pois mudanças nas políticas públicas relacionadas aos povos indígenas dependem, fundamentalmente, do seu protagonismo. Esse comprometimento dos pesquisadores indígenas é um dos fatores que remetem para a continuidade do trabalho, em especial a sua extensão a outras aldeias. Os jovens que participaram, diretamente, do trabalho mostraram grande interesse e entusiasmo pela realização da pesquisa.

Outra discussão foi sobre o tempo de permanência nos locais de trajetórias, para que um deslocamento fosse considerado. Os Kaiowá e Guarani de Te'ýikue decidiram que deveria ser a partir de três meses. A permanência exclusivamente para trabalho foi contemplada numa outra pergunta com menor tempo de estadia. Este dado, infelizmente, ainda não pôde ser tabulado.

Definimos também que o idioma do questionário seria o português, e alguns termos seriam mantidos em guarani e em português. Conversamos muito a respeito dos termos, como, por exemplo, avó, que, em guarani, teria de ser traduzido ora como "mãe do pai", ora como "mãe da mãe".

Outra decisão foi com relação ao conceito de domicílio. Como as casas de uma família são dispersas, às vezes, num mesmo conjunto, estão localizadas a casa do filho solteiro e a cozinha da família.

Durante a aplicação dos questionários ou a realização das entrevistas foi importante a revisão, em campo, das informações. Dessa forma, muitas respostas que apresentavam imprecisões foram esclarecidas. Em relação à metodologia, percebeu-se que os mais velhos preferem falar de assuntos de seu interesse. Assim, alguns entrevistadores deixavam os mais velhos falarem bastante primeiro, e depois iniciavam as perguntas do questionário. Como relata Alex Junior: "alguns contavam tanta história que demorava muito, a pessoa contava tudo primeiro, depois é que se iniciavam as perguntas" (Colman et al., 2010: 21). Ouvir antes e valorizá-los é uma das características próprias da pesquisa com indígenas, observada por Enoque Batista (2006: 140): "Não deixo também o entrevistado, depois de falar, sem incentivo. Sempre comento da história, do mito ou do conto, que são assuntos que ele gosta. Tudo que ele conta considero muito importante. Assim eles se sentem bem". Em contrapartida, alguns entrevistados "só respondiam ao que se perguntava", como Alex Junior também observou (Colman et al., 2010: 21).

Na realização da pesquisa, a amostragem significou 34,12\% dos domicílios de Caaparó. Do total de 1.140 unidades, foram entrevistadas 401, mas, apenas 389 entrevistas foram tabuladas e puderam ser utilizadas.

Dos 389 entrevistados, 102 (26,22\%) moram em Ñandejára, uma das regiões mais populosas localizada na região central, que concentra os serviços, 
como escola de ensino fundamental e ensino médio, posto de saúde e centro de referência da assistência social. É também a área em que reside a maior parte dos entrevistados.

No início do levantamento, havia sido proposto realizar a entrevista em $40 \%$ dos domicílios de cada região. Na região de Mbopiy, foram entrevistadas todas as unidades e, na região de Yvu, apenas 6,4\%. Em termos gerais, foram atingidos $34,12 \%$ dos domicílios. As desproporções ocorreram por dificuldades de acesso, decorrentes da grande distância entre a moradia do entrevistador e as dos entrevistados. Havia também a preferência por entrevistar os próprios parentes e vizinhos.

Com relação ao perfil dos entrevistados, a maior parte nasceu em Caarapó. Dos 389 entrevistados, 268 nasceram em Te'ýikue (Caarapó), e 264 são mulheres e 125 homens, indicando que as mulheres são, na maior parte, as responsáveis pelos domicílios e estavam presentes no momento da entrevista. A maioria dos entrevistados são Kaiowá, 92,54\%; os Guarani correspondem a apenas 7,46\%. Sobre o estado civil dos entrevistados: $80,98 \%$ são casados, $11,57 \%$ viúvos ou separados e $7,46 \%$ solteiros. Foi usado como critério entrevistar preferencialmente pessoas casadas para otimizar a entrevista e obter informações também do cônjuge e sogros. Em relação à faixa etária, verificamos que a maioria dos entrevistados era jovem: 170 entre 14 e 30 anos, 171 entre 31 e 60 anos, apenas 45 tinham 61 anos ou mais.

Dos 389 entrevistados, 56,04\% apresentaram alguma trajetória migratória, e 43,96\% não apresentaram nenhuma trajetória.

A partir de meados do século XX, principalmente nos anos 1960 e 1970, os Guarani começavam a enfrentar o fenômeno da grande concentração populacional nas reservas/terras indígenas, o que forçava essa população a uma mudança de estilo de vida: a progressiva substituição da sobrevivência por meio da caça, roça, pesca e coleta pelo trabalho assalariado fora da aldeia, obrigando esses grupos a se deslocarem, como está bem demonstrado na Tabela 1.

Observamos que, na trajetória 1, 14 deslocamentos ocorreram por razões familiares, como para estar perto da família ou reunir os parentes.

No levantamento realizado surgiu, como principal motivo de deslocamento, a moradia, desafiando-nos para um aprofundamento dessa questão, em pesquisas mais qualitativas. A Tabela 2 indica uma das especificidades das trajetórias dos Kaiowá e Guarani de Te'ýikue, que é a mobilidade espacial familiar, mostrando que a maior parte dos entrevistados se move em grupo. 
Tabela 1 - Motivos das trajetórias dos entrevistados

\begin{tabular}{|c|c|c|c|c|c|c|c|}
\hline \multirow{2}{*}{ Motivos } & \multicolumn{7}{|c|}{ Trajetórias } \\
\hline & 1 & 2 & 3 & 4 & 5 & 6 & 7 a 14 \\
\hline Questões familiares & 14 & 9 & 4 & 10 & 7 & 3 & 5 \\
\hline Separação & 3 & 2 & 2 & 2 & 2 & 2 & 2 \\
\hline Casamento & 7 & 3 & 5 & 2 & 1 & 1 & 2 \\
\hline Conflito interno & 1 & 1 & 1 & 2 & 1 & 1 & - \\
\hline Morar & 90 & 80 & 38 & 19 & 9 & 11 & 7 \\
\hline Estudar & 5 & 4 & 1 & - & 1 & 4 & 3 \\
\hline Questões de terra/expulsões e retomadas & 4 & 3 & 2 & - & 3 & 1 & - \\
\hline Falecimento & 2 & 2 & - & 3 & - & - & - \\
\hline Benefícios & 2 & - & 1 & - & - & - & - \\
\hline Passeio/visita & 30 & 9 & 5 & - & - & - & 1 \\
\hline Trabalhar & 53 & 49 & 35 & 24 & 18 & 8 & 19 \\
\hline Tratamento de saúde & 1 & - & 1 & 2 & - & - & - \\
\hline Total & 212 & 162 & 95 & 64 & 42 & 31 & 39 \\
\hline
\end{tabular}

Fonte: elaborado pelas autoras com base no projeto de pesquisa Mobilidade Espacial Guarani e Kaiowá, 2009.

Tabela 2 - Acompanhantes durante as trajetórias dos entrevistados

\begin{tabular}{l|r|r|r|r|r|r|r}
\hline \multirow{2}{*}{ Acompanhantes } & \multicolumn{7}{|c}{ Trajetórias } \\
\cline { 2 - 8 } & \multicolumn{1}{|c}{1} & \multicolumn{1}{c}{2} & \multicolumn{1}{c}{3} & \multicolumn{1}{c}{4} & \multicolumn{1}{c}{5} & 6 & 7 a 14 \\
\hline Sozinho & 35 & 39 & 31 & 23 & 8 & 4 & 12 \\
\hline Pais (mãe/pai) & 41 & 32 & 14 & 8 & 3 & - & 1 \\
\hline Esposo(a) & 16 & 22 & 12 & 4 & 9 & 6 & 6 \\
\hline Outros parentes (tios/avós) & 5 & 5 & 3 & - & 1 & 1 & - \\
\hline Conhecidos/amigos & 2 & 4 & 2 & 1 & 1 & - & - \\
\hline Irmão & 24 & 2 & 2 & - & 1 & 1 & - \\
\hline Toda a família & 32 & 43 & 26 & 22 & 12 & 16 & 22 \\
\hline Comunidade & 4 & - & - & - & - & - & - \\
\hline Patrão & 4 & 7 & 4 & 2 & 2 & - & - \\
\hline Filho(s) & 1 & 6 & 1 & 2 & 3 & 1 & - \\
\hline Total & 164 & 160 & 95 & 62 & 40 & 29 & 41 \\
\hline
\end{tabular}

Fonte: elaborado pelas autoras com base no projeto de pesquisa Mobilidade Espacial Guarani e Kaiowá, 2009. 
Com relação ao tempo de permanência nos locais de destino, na Tabela 3 verificamos três padrões de temporalidade. Um é de curto tempo de permanência, que vai desde menos de um ano até dois anos, e compõe a maioria dos deslocamentos espaciais referidos pelos entrevistados na pesquisa de Caarapó. Outro padrão tem maior duração, mais de dez anos, e perfaz, também, um número expressivo de deslocamentos espaciais referidos: são deslocamentos feitos, majoritariamente, por motivo de moradia, mudança para outra região; enquanto, no padrão anterior, o motivo principal é o trabalho assalariado. O terceiro padrão é de média duração e vai de dois a dez anos: o motivo é tanto trabalho assalariado de maior tempo de duração, quanto visitas à família, passeios, casamento etc.

Tabela 3 - Tempo de permanência dos entrevistados

\begin{tabular}{|c|c|c|c|c|c|c|c|}
\hline \multirow{2}{*}{ Tempo } & \multicolumn{7}{|c|}{ Trajetórias } \\
\hline & 1 & 2 & 3 & 4 & 5 & 6 & 7 a 14 \\
\hline menos de 1 ano & 20 & 27 & 23 & 8 & 8 & 5 & 12 \\
\hline de 1 a 2 anos & 45 & 27 & 23 & 17 & 8 & 6 & 9 \\
\hline de 2 a 5 anos & 31 & 23 & 7 & 10 & 8 & 8 & - \\
\hline de 5 a 10 anos & 41 & 10 & 10 & 5 & 4 & 0 & 5 \\
\hline mais de 10 anos & 34 & - & 5 & 5 & 4 & 2 & 2 \\
\hline Total & 171 & 87 & 68 & 45 & 32 & 21 & 28 \\
\hline
\end{tabular}

Fonte: elaborado pelas autoras com base no projeto de pesquisa Mobilidade Espacial Guarani e Kaiowá, 2009.

As Tabelas 4 e 5 informam o tipo de local de nascimento e as trajetórias dos entrevistados e dos cônjuges. Na Tabela 4, apresentamos dados sobre os entrevistados. O número máximo de trajetórias foi 14 , sendo que os principais lugares visitados são as reservas, incluindo a reserva de Caarapó (Te'ýikue). Isto indica que os moradores vão para muitos lugares, mas voltam várias vezes para Caarapó, lugar de origem, já que a maior parte dos entrevistados é nascida nessa aldeia. Há um número expressivo de deslocamentos espaciais para aldeias antigas, que são as áreas de ocupação tradicional dos Guarani, o que caracteriza a situação de expulsão dos grupos dessas aldeias, destruídas e transformadas em fazendas.

Os deslocamentos espaciais para fazendas e cidades têm relação direta com um dos principais motivos de mobilidade espacial: a busca de trabalho. Dentre as reservas que aparecem com maior frequência, estão Amambai e Dourados e indicam o tekoha guasu, ${ }^{1}$ do qual Te'ýikue (Caarapó) faz parte. Este tekoha guasu abrange também os Tekoha de Dourados e os Tekoha de Amambai. 
Tabela 4 - Tipo de local de nascimento e trajetórias dos entrevistados

\begin{tabular}{|c|c|c|c|c|c|c|c|c|}
\hline \multirow{2}{*}{ Tipos de local } & \multirow{2}{*}{ Nasc. } & \multicolumn{7}{|c|}{ Trajetórias } \\
\hline & & 1 & 2 & 3 & 4 & 5 & 6 & 7 a 14 \\
\hline Reservas & 332 & 122 & 118 & 54 & 34 & 19 & 17 & 22 \\
\hline $\begin{array}{l}\text { Loc. tradicionais/atuais } \\
\text { fazendas }\end{array}$ & 21 & 16 & 2 & 5 & 4 & 3 & 3 & 2 \\
\hline Cidades & 12 & 18 & 8 & 6 & 7 & 4 & 5 & 3 \\
\hline $\begin{array}{l}\text { TIs recentes ou em } \\
\text { demarcação }\end{array}$ & 9 & 24 & 18 & 15 & 7 & 9 & 4 & 3 \\
\hline Paraguai & 8 & 12 & 2 & 3 & 1 & - & - & 3 \\
\hline Fazendas & 6 & 18 & 10 & 8 & 4 & - & - & 5 \\
\hline $\begin{array}{l}\text { Outros estados (PR, } \\
\text { RO, SP, AM, MT) }\end{array}$ & 1 & - & 2 & 3 & 1 & - & - & 1 \\
\hline Usinas & - & - & 2 & 1 & - & - & 1 & - \\
\hline Argentina/Bolívia & - & - & - & - & - & - & - & - \\
\hline Total & 389 & 210 & 162 & 95 & 58 & 35 & 30 & 39 \\
\hline
\end{tabular}

Fonte: elaborado pelas autoras com base no projeto de pesquisa Mobilidade Espacial Guarani e Kaiowá, 2009.

Na Tabela 5 constam as informações sobre o cônjuge do entrevistado.

O número máximo de trajetórias foi 12 . Os principais lugares visitados são também as reservas, em que se inclui a reserva de Caarapó (Te'ýikue). Isto indica a mesma situação de deslocamentos espaciais dos entrevistados e das entrevistadas.

Tabela 5 - Tipo de local de nascimento e trajetórias dos cônjuges dos entrevistados

\begin{tabular}{|c|c|c|c|c|c|c|c|}
\hline \multirow{2}{*}{ Tipos de local } & \multirow{2}{*}{ Nasc. } & \multicolumn{6}{|c|}{ Trajetórias } \\
\hline & & 1 & 2 & 3 & 4 & 5 & 6 a 12 \\
\hline Reservas & 285 & 93 & 64 & 38 & 23 & 15 & 18 \\
\hline Loc. tradicionais/atuais fazendas & 10 & 5 & 1 & 4 & 3 & 3 & 1 \\
\hline Cidades & 15 & 6 & 7 & 3 & 6 & 1 & 2 \\
\hline TIs recentes ou em demarcação & 11 & 22 & 15 & 6 & 3 & 2 & 2 \\
\hline Paraguai & 6 & 10 & 4 & 4 & 1 & - & 4 \\
\hline Fazendas & 7 & 13 & 7 & 2 & - & 2 & 2 \\
\hline Outros estados (PR, RO, SP, AM, MT) & 3 & 2 & 1 & 2 & - & - & - \\
\hline Usinas & - & 1 & 1 & 1 & - & - & - \\
\hline Argentina/Bolívia & - & - & - & - & - & - & - \\
\hline Total & 337 & 152 & 100 & 60 & 36 & 23 & 29 \\
\hline
\end{tabular}

Fonte: elaborado pelas autoras com base no projeto de pesquisa Mobilidade Espacial Guarani e Kaiowá, 2009. 
As Tabelas 6 e 7 apresentam informações de uma geração acima do entrevistado. A situação é semelhante, com as mesmas características dos entrevistados e cônjuges, principalmente com relação às reservas. A diferença constatada é a maior quantidade de locais de nascimento (27) e trajetórias (14) no Paraguai. Como é uma trajetória masculina, também a questão do trabalho nas fazendas é um motivo que aparece de forma expressiva (17).

Tabela 6 - Tipo de local de nascimento/falecimento e trajetórias dos pais dos entrevistados

\begin{tabular}{|c|c|c|c|c|c|c|c|c|}
\hline \multirow{2}{*}{ Tipo de local } & \multirow{2}{*}{ Nasc. } & \multirow{2}{*}{ Falec. } & \multicolumn{6}{|c|}{ Trajetórias } \\
\hline & & & 1 & 2 & 3 & 4 & 5 & 6 a 12 \\
\hline Reservas & 265 & 135 & 89 & 57 & 31 & 16 & 12 & 15 \\
\hline Loc. tradicionais/atuais fazendas & 14 & 7 & 9 & 13 & 1 & - & 2 & 2 \\
\hline Cidades & 14 & 2 & 6 & 7 & 5 & 2 & 2 & 1 \\
\hline TIs recentes ou em demarcação & 16 & 9 & 18 & 13 & 7 & 4 & 2 & 2 \\
\hline Paraguai & 27 & 6 & 14 & 4 & 8 & - & - & - \\
\hline Fazendas & 17 & 1 & 16 & 6 & 3 & 11 & 4 & 5 \\
\hline Outros estados (PR, RO, SP, AM, MT) & 7 & - & 1 & 3 & - & - & - & - \\
\hline Usinas & - & - & - & - & 1 & 1 & - & - \\
\hline Argentina/Bolívia & - & - & - & - & - & - & - & - \\
\hline Total & 360 & 160 & 153 & 103 & 55 & 34 & 22 & 25 \\
\hline
\end{tabular}

Fonte: elaborado pelas autoras com base no projeto de pesquisa Mobilidade Espacial Guarani e Kaiowá, 2009.

Com relação ao tipo de local de nascimento e trajetórias das mães dos entrevistados, chama atenção o grande número, também, de mulheres que nasceram no Paraguai e escolheram esse país como lugar de destino, além, é claro, das reservas, como mencionado anteriormente. Na Tabela 7, ocorrem nove trajetórias, quantidade que também chama atenção, sendo que uma pessoa foi para Argentina.

Tabela 7 - Tipo de local de nascimento/falecimento e trajetórias das mães dos entrevistados

\begin{tabular}{|c|c|c|c|c|c|c|c|c|}
\hline \multirow{2}{*}{ Tipo de local } & \multirow{2}{*}{ Nasc. } & \multirow{2}{*}{ Falec. } & \multicolumn{6}{|c|}{ Trajetórias } \\
\hline & & & 1 & 2 & 3 & 4 & 5 & 6 a 9 \\
\hline Reservas & 274 & 98 & 106 & 72 & 32 & 19 & 12 & 18 \\
\hline Loc. tradicionais/atuais fazendas & 24 & 3 & 11 & 9 & 5 & 2 & - & 2 \\
\hline Cidades & 11 & 3 & 15 & 4 & 3 & 1 & - & 2 \\
\hline TIs recentes ou em demarcação & 17 & 7 & 20 & 14 & 11 & 8 & 5 & 7 \\
\hline Paraguai & 26 & 3 & 13 & 1 & - & 1 & 3 & - \\
\hline Fazendas & 14 & - & 6 & 6 & 6 & 5 & 2 & - \\
\hline Outros estados (PR, RO, SP, AM, MT) & 1 & - & 2 & 1 & - & - & - & - \\
\hline
\end{tabular}


Tabela 7 - Tipo de local de nascimento/falecimento e trajetórias das mães dos entrevistados (cont.)

\begin{tabular}{|c|c|c|c|c|c|c|c|c|}
\hline \multirow{2}{*}{ Tipo de local } & \multirow{2}{*}{ Nasc. } & \multirow{2}{*}{ Falec. } & \multicolumn{6}{|c|}{ Trajetórias } \\
\hline & & & 1 & 2 & 3 & 4 & 5 & 6 a 9 \\
\hline Usinas & - & - & - & - & - & - & - & - \\
\hline Argentina/Bolívia & - & - & 1 & - & - & - & - & - \\
\hline Total & 367 & 114 & 174 & 107 & 57 & 36 & 22 & 25 \\
\hline
\end{tabular}

Fonte: elaborado pelas autoras com base no projeto de pesquisa Mobilidade Espacial Guarani e Kaiowá, 2009.

A Tabela 8 apresenta informações de duas gerações acima do entrevistado, isto é, seus avós maternos e paternos. Foram tabuladas informações sobre local de nascimento e falecimento. O dado novo é um caso de uma pessoa que nasceu na Bolívia. Também chama atenção o maior número de pessoas que nasceram no Paraguai.

Tabela 8 - Tipo de local de nascimento/falecimento dos avós dos entrevistados

\begin{tabular}{l|r|r|r|r|r|r|r|r}
\hline \multirow{2}{*}{ Tipo de local } & \multicolumn{2}{|c|}{ Avô materno } & \multicolumn{2}{c|}{ Avó materna } & \multicolumn{2}{c}{ Avô paterno } & \multicolumn{2}{c}{ Avó paterna } \\
\cline { 2 - 11 } & Nasc. & \multicolumn{1}{|c|}{ Falec. } & Nasc. & Falec. & Nasc. & Falec. & Nasc. & Falec. \\
\hline Reservas & 191 & 167 & 208 & 165 & 185 & 162 & 184 & 141 \\
\hline Loc. tradicionais/atuais fazendas & 9 & 6 & 15 & 1 & 11 & 8 & 8 & 9 \\
\hline Cidades & 12 & 7 & 10 & 7 & 14 & 6 & 9 & 7 \\
\hline TIs recentes ou em demarcação & 10 & 9 & 9 & 12 & 10 & 15 & 13 & 10 \\
\hline Paraguai & 44 & 16 & 37 & 13 & 24 & 13 & 18 & 5 \\
\hline Fazendas & 4 & 6 & 5 & 2 & 4 & 2 & 2 & 1 \\
\hline Outros estados (PR, RO, SP, AM, MT) & 6 & 2 & 1 & - & 6 & 1 & 3 & 2 \\
\hline Usinas & - & - & - & - & - & 1 & - & - \\
\hline Argentina/Bolívia & - & - & - & - & 1 & - & - & - \\
\hline Total & 276 & 213 & 285 & 200 & 255 & 208 & 237 & 175 \\
\hline
\end{tabular}

Fonte: elaborado pelas autoras com base no projeto de pesquisa Mobilidade Espacial Guarani e Kaiowá, 2009.

Com relação ao tipo de local, as reservas de Amambai e Dourados são as que tiveram maiores frequências, como dito anteriormente. As TIs recentes ou em demarcação, que mais aparecem, são Guyra Roka, Takuara, Jarara, Guaimbé e Rancho Jacaré. No Paraguai, a aldeia em destaque é Piray. As cidades que mais aparecem são Juti e Navirai. Juti, provavelmente, porque os Kaiowá do Jarara ficaram muito tempo vivendo na periferia da cidade, e Navirai, possivelmente, tem relação com o trabalho na usina desta cidade. Os locais tradicionais que, na época, eram propriedades particulares ou fazendas e que têm mais ocorrências são: Javorai, São Lucas e Campanário. 
Apresentamos, a seguir, dois exemplos de trajetórias, para visualizarmos alguns detalhes interessantes. Na trajetória da entrevistada A (Quadro 1), chama atenção o percurso feito de ida e volta para estar com parentes e para ir trabalhar. Nos lugares por onde ela se deslocou, Te'ýikue aparece várias vezes. Com certeza houve mais momentos de volta para casa, mas que, por ter sido limitado o tempo de permanência dos deslocamentos espaciais em três meses, não foi possível captá-los. Mas, na trajetória do entrevistado B (Quadro 2), não se levou em conta, em alguns momentos, o tempo mínimo de três meses de permanência no local para ser considerado como deslocamento, conforme tomadas de decisões, mencionadas anteriormente, do entrevistador. Além disso, aparece a ida para casa em dois momentos: um de uma semana e outro de dois meses de tempo de permanência no local. Destacamos esses dois casos também pelo número de trajetórias dos entrevistados A e B: o primeiro apresenta 14 eventos e o segundo 16.

Outro fato que chama a atenção no relato da entrevistada A é o deslocamento para as fazendas da região para trabalhar: inicialmente com o esposo e, depois de ter filhos, sempre com eles também. Nos relatos do entrevistado B, o que se destaca é o início de sua trajetória: desde criança, para acompanhar os pais que iam trabalhar na erva mate, pois na época era muito comum essa atividade.

A pergunta "com quem andou?" durante as trajetórias indica também elementos do ciclo de vida da pessoa, como o casamento do entrevistado, evento a partir do qual que se movem. No caso do entrevistado B, inicialmente o deslocamento foi feito com os pais, depois sozinho, em seguida com a esposa e, na sequência, com a família, sinalizando a presença de filhos.

Nesses deslocamentos espaciais, foi possível observar a dinâmica da changa, atividade braçal temporária muito comum entre os Kaiowá e Guarani, verificada, principalmente, até a década de 1980, em que o indígena saía do lugar de residência para ir trabalhar numa região próxima, por períodos curtos de três a quatro meses e retornava para casa, fazia sua roça e voltava para outra changa. Como foi estabelecido na pesquisa que seria mapeado um período mínimo de três meses de duração dos deslocamentos espaciais, em algumas situações não aparece sinalizado no banco de dados o retorno à casa, pois a volta ocorria muitas vezes em um período inferior a três meses (uma semana, 15 dias, um mês, dois meses). 
Quadro 1 - Entrevistada A, Kaiowá, viúva, 43 anos (1966), de Te'ýikue (Caarapó, MS), residente em Jakaira

\begin{tabular}{|c|c|c|c|c|c|}
\hline $\begin{array}{c}\text { N. de } \\
\text { trajetórias }\end{array}$ & $\begin{array}{l}\text { Nome dos lugares } \\
\text { (aldeia/estado/país) }\end{array}$ & $\begin{array}{c}\text { Por que você } \\
\text { foi para esse } \\
\text { lugar? }\end{array}$ & $\begin{array}{l}\text { Com quem } \\
\text { foi? }\end{array}$ & $\begin{array}{c}\text { Quando foi? } \\
\text { (em ano ou } \\
\text { idade) }\end{array}$ & $\begin{array}{c}\text { Por quanto } \\
\text { tempo? (em } \\
\text { anos ou meses) }\end{array}$ \\
\hline 1 & $\begin{array}{l}\text { Fazenda Paketa (Laguna } \\
\text { Carapã, MS, BR) }\end{array}$ & trabalhar & esposo & 18 anos (1984) & 6 meses \\
\hline 2 & $\begin{array}{l}\text { Faz. Tramontina (Ponta } \\
\text { Porã, MS, BR) }\end{array}$ & trabalhar & esposo & 18 anos (1984) & 3 meses \\
\hline 3 & $\begin{array}{l}\text { Faz. } 3 \text { de Março (Navirai, } \\
\text { MS, BR) }\end{array}$ & trabalhar & família & 18 anos (1984) & 4 meses \\
\hline 4 & Faz.Taruma (Juti, MS, BR) & trabalhar & família & 19 anos (1985) & 9 meses \\
\hline 5 & Te'yikue (Caarapó, MS, BR) & $\begin{array}{l}\text { estar perto } \\
\text { dos parentes }\end{array}$ & família & 19 anos (1985) & 6 meses \\
\hline 6 & $\begin{array}{l}\text { Faz. Terezinha (Caarapó, } \\
\text { MS, BR) }\end{array}$ & trabalhar & família & 20 anos (1986) & 3 meses \\
\hline 7 & $\begin{array}{l}\text { Faz. Usiladora (Itaquirai, } \\
\text { MS, BR) }\end{array}$ & trabalhar & família & 20 anos (1986) & 7 meses \\
\hline 8 & Te'ýikue (Caarapó, MS, BR) & $\begin{array}{l}\text { volta de } \\
\text { muito } \\
\text { trabalho }\end{array}$ & família & 21 anos (1987) & 3 meses \\
\hline 9 & $\begin{array}{l}\text { Faz. Progresso (Caarapó, } \\
\text { MS, BR) }\end{array}$ & trabalhar & família & 21 anos (1987) & 8 meses \\
\hline 10 & Te'ýikue (Caarapó, MS, BR) & $\begin{array}{l}\text { volta do } \\
\text { trabalho }\end{array}$ & família & 21 anos (1987) & 3 meses \\
\hline 11 & $\begin{array}{l}\text { Limão Verde (Amambai, } \\
\text { MS, BR) }\end{array}$ & morar & família & 22 anos (1988) & 4 meses \\
\hline 12 & Te'ýikue (Caarapó, MS, BR) & morar & família & 22 anos (1988) & 7 meses \\
\hline 13 & $\begin{array}{l}\text { Takuapiry (Coronel } \\
\text { Sapucaia, MS, BR) }\end{array}$ & morar & família & 23 anos (1988) & 9 anos \\
\hline 14 & Te'ýikue (Caarapó, MS, BR) & morar & família & 32 anos (1995) & até hoje \\
\hline
\end{tabular}

Fonte: elaborado pelas autoras com base no projeto de pesquisa Mobilidade Espacial Guarani e Kaiowá, 2009. 
Quadro 2 - Entrevistado B, Kaiowá, viúvo, 99 anos (1910), de Campanário (Caarapó, MS), residente em Ñandejára

\begin{tabular}{|c|c|c|c|c|c|}
\hline $\begin{array}{l}\text { N. de } \\
\text { trajetórias }\end{array}$ & $\begin{array}{l}\text { Nome dos lugares } \\
\text { (aldeia/estado/país) }\end{array}$ & $\begin{array}{l}\text { Por que foi } \\
\text { para esse } \\
\text { lugar? }\end{array}$ & $\begin{array}{l}\text { Com quem } \\
\text { foi? }\end{array}$ & $\begin{array}{c}\text { Quando foi? } \\
\text { (em anos ou } \\
\text { idade) }\end{array}$ & $\begin{array}{c}\text { Por quanto } \\
\text { tempo? (em } \\
\text { anos ou meses) }\end{array}$ \\
\hline 1 & Tajy (Ponta Porã, MS, BR) & $\begin{array}{l}\text { trabalhar na } \\
\text { erva mate }\end{array}$ & pais & 7 anos (1917) & 3 anos \\
\hline 2 & $\begin{array}{l}\text { Amambai (Amambai, } \\
\text { MS, BR) }\end{array}$ & morar & pais & 10 anos (1920) & 3 anos \\
\hline 3 & Paraná $(\mathrm{BR})^{*}$ & trabalhar & sozinho & 15 anos (1925) & 3 meses \\
\hline 4 & Ñakyrãy (Takuru, MS, BR) & trabalhar & sozinho & 15 anos (1925) & 4 meses \\
\hline 5 & $\begin{array}{l}\text { Amambai (Amambai, } \\
\text { MS, BR) }\end{array}$ & $\begin{array}{l}\text { voltar para } \\
\text { casa }\end{array}$ & sozinho & 15 anos (1925) & 1 semana \\
\hline 6 & Ñakyrãy (Takuru, MS, BR) & trabalhar & sozinho & 15 anos (1925) & 3 meses \\
\hline 7 & $\begin{array}{l}\text { Rancho Tyjuru, Cerrito } \\
\text { (Eldorado, MS, BR) }\end{array}$ & trabalhar & sozinho & 16 anos (1926) & 1 ano \\
\hline 8 & $\begin{array}{l}\text { Ypytã, Limão Verde } \\
\text { (Amambai, MS, BR) }\end{array}$ & $\begin{array}{c}\text { trabalhar na } \\
\text { erva mate }\end{array}$ & sozinho & 17 anos (1927) & 3 meses \\
\hline 9 & $\begin{array}{l}\text { Porto Tajy, Sassoro } \\
\text { (Tacuru, MS, BR) }\end{array}$ & $\begin{array}{c}\text { trabalhar na } \\
\text { erva mate }\end{array}$ & sozinho & 17 anos (1927) & 8 meses \\
\hline 10 & $\begin{array}{l}\text { Rancho Seyro/Cedro } \\
\text { (Paraguai) }\end{array}$ & $\begin{array}{l}\text { trabalhar na } \\
\text { erva mate }\end{array}$ & sozinho & 18 anos (1928) & 1 ano \\
\hline 11 & $\begin{array}{l}\text { Salamanca (fronteira } \\
\text { com Paraguai) }\end{array}$ & trabalhar & sozinho & 18 anos (1928) & 3 meses \\
\hline 12 & $\begin{array}{l}\text { Faz. Teixeira (Lagunita, } \\
\text { Laguna Carapã, MS, BR) }\end{array}$ & passeio & esposa & 18 anos (1928) & 5 meses \\
\hline 13 & $\begin{array}{l}\text { Faz. Tiburcio Bezino } \\
\text { (Lagunita Laguna } \\
\text { Carapã, MS, BR) }\end{array}$ & trabalhar & $\begin{array}{l}\text { esposa e } \\
\text { filhos }\end{array}$ & 18 anos (1928) & 4 meses \\
\hline 14 & $\begin{array}{l}\text { Paso ka'u (Aral Moreira, } \\
\text { MS, BR) }\end{array}$ & trabalhar & esposa & 19 anos (1929) & 9 anos \\
\hline 15 & $\begin{array}{l}\text { Fazenda Rincom (Laguna } \\
\text { Carapã, MS, BR) }\end{array}$ & $\begin{array}{l}\text { trabalhar na } \\
\text { erva mate }\end{array}$ & esposa & 28 anos (1938) & 8 meses \\
\hline 16 & Te'ýikue (Caarapó, MS, BR) & morar & família & 28 anos (1938) & até hoje \\
\hline
\end{tabular}

* Não apareceu o nome da aldeia na entrevista.

Fonte: elaborado pelas autoras com base no projeto de pesquisa Mobilidade Espacial Guarani e Kaiowá, 2009. 


\section{Considerações finais}

Os principais resultados que obtivemos neste estudo são as diversas características que envolvem a dinâmica migratória entre os Guarani e Kaiowá. A primeira é a circularidade da mobilidade espacial guarani, ou seja, acontece em etapas, daí a importância de se investigarem histórias e biografias migratórias.

A segunda característica observada são as migrações forçadas, tratadas pelos Guarani e Kaiowá como Ñemosarambipa (grande esparramo). A terceira é conhecida como Ojeguata porã (bela caminhada).

Além disso, compreendemos que os Guarani se movem em grupos, com parentes, em decorrência de fatos que tradicionalmente ocorrem nas aldeias: brigas, casamentos, visitas de parentes etc. E, por último, os Guarani se movem como jovens indivíduos que saem para estudar ou para trabalhar.

Os tipos de mobilidade espacial analisados, conforme os exemplos apresentados anteriormente, têm impacto direto na implementação dos direitos dos povos Guarani relativos à documentação, educação escolar, terra e saúde. Em relação à educação, por exemplo, constata-se que muitas crianças chegam a Caarapó e solicitam o ingresso na escola, porém não trazem os papéis de transferência ou não têm documentação necessária. A escola Ñandejára Polo tem o mérito de aceitar esses alunos; posteriormente tentam resolver, junto com as famílias, a situação dos documentos. Mas a dificuldade administrativa e burocrática permanece, fazendo com que muitas crianças fiquem fora da escola, infringindo os direitos fundamentais dos Guarani.

Observa-se que os alunos e suas famílias não têm condições nem habilidades para conseguir superar esses problemas. Inversamente, se a família se muda para outra unidade da federação, vai para o Paraguai ou vem deste país, a situação se agrava mais ainda, por causa da falta de documentação e da incompatibilidade entre os sistemas de ensino. Esse fato, em si, talvez não constituísse um problema, porque os jovens poderiam se adaptar, mas as equipes das escolas e da administração escolar, em geral, utilizam esse argumento para dificultar a matrícula de alunos novos, principalmente fora do calendário letivo.

Na área de saúde há, principalmente, dois tipos de dificuldades: uma é a situação de pessoas em trânsito, que não constam nos cadastros da Fundação Nacional de Saúde/ Sistema de Informação da Atenção à Saúde Indígena (Funasa/ Siasi) e, por isso, muitas vezes não conseguem receber tratamento por não constarem no cadastro naquele polo-base onde estão residindo no momento. Nesses casos, o histórico de saúde não é conhecido pelas equipes de saúde, o que dificulta enormemente o diagnóstico e o tratamento de qualquer enfermidade. Outra situação diz respeito às famílias que chegam a Caarapó e demoram para conseguir a documentação pessoal e, quando precisam de serviços de saúde, não são atendidos, 
pois os postos de atendimento, pronto-socorro e os polos-base não atendem aqueles que não apresentam o registro de nascimento.

A questão da demarcação das terras para os Guarani e Kaiowá, nos últimos 15 anos pelo menos, permanece como um problema e já foi tratado em inúmeros documentos oficiais e não oficiais. A mobilidade espacial voluntária das famílias fica prejudicada, seja pelo clima de violência que continua, seja pelo enorme preconceito que vem aumentando, em decorrência da deterioração cada vez maior das relações interétnicas entre os indígenas e os não indígenas das cidades vizinhas. As migrações forçadas e os acampamentos de beira de estrada também estão crescendo em número e em violência. Todos esses fatos caracterizam uma situação de desrespeito aos direitos humanos e aos direitos específicos dos povos indígenas.

Nota

1 Tekoha equivale à terra indígena. Em guarani, Teko é "vida", "modo de ser", "cultura", e ha significa espaço. Tekoha, portanto, significa lugar em que o modo de ser é viável ou possível, e tekoha guasu envolve mais de um tekoha em que se estabelecem relações.

\section{Referências}

BATISTA, E. Fazendo pesquisa com meu povo. Tellus, 6 (10): 139-142, 2006.

BENITES, E. Oguata Pyahu (Uma Nova Caminhada): o processo de desconstrução e construção da educação escolar indígena da reserva indígena Te'ýikue, 2014. Dissertação de Mestrado, Campo Grande: Universidade Católica Dom Bosco.

BRAND, A. J. O Impacto da Perda da Terra sobre a Tradição Kaiowá/Guarani: os difíceis caminhos da palavra, 1997. Tese de Doutorado, Porto Alegre: Faculdade de Filosofia e Ciências Humanas, Pontifícia Universidade Católica do Rio Grande do Sul.

COLMAN, R. S. Guarani Retã e Mobilidade Espacial Guarani: belas caminhadas e processos de expulsão no território guarani, 2015. Tese de Doutorado, Campinas: Instituto de Filosofia e Ciências Humanas, Universidade Estadual de Campinas.

COLMAN, R. S. et al. Mobilidade espacial Guarani e Kaiowá. In: ENCONTRO NACIONAL DE ESTUDOS POPULACIONAIS, XVII, 2010. Disponível em: <www.abep.nepo.unicamp.br/ encontro2010>. Acesso em: 8 mar. 2012.

DEL POPOLO, F. G RIBOTTA, B. Migración de jóvenes indígenas en América Latina. In: DEL POPOLO, F. et al. (Orgs.). Pueblos Indígenas y Afrodescendientes en América Latina: dinámicas poblacionales diversas y desafíos comunes. Rio de Janeiro: Alap, 2011. 
ECHEVERRI, H. M. La Población Indígena y las Ciudades. Organización Indígena de Colombia (ONIC), 2012. Disponível em: <http://observatorioetnicocecoin.org.co>. Acesso em: 11 set. 2014.

EQUIPE MAPA GUARANI CONTINENTAL (EMGC). Caderno Mapa Guarani Continental: povos Guarani na Argentina, Bolívia, Brasil e Paraguai. Campo Grande, MS. Cimi, 2016. Disponível em: <www.guarani.roguata.com/content/mapa-guarani-continental-2016>. Acesso em: 5 ago. 2019.

ESTANISLAU, B. R. A Eterna Volta: migração indígena e Pankararu no Brasil, 2014. Dissertação de Mestrado, Campinas: Instituto de Filosofia e Ciências Humanas, Universidade Estadual de Campinas.

INSTITUTO INTERAMERICANO DE DERECHOS HUMANOS (IIDH). Migraciones Indígenas en las Américas. San José: IIDH, 2007.

MELIÀ, B. Desafios e tendências na alfabetização em língua indígena. In: EMIRI, L. G MONSERRAT, R. (Orgs.). A Conquista da Escrita: encontros de educação indígena Opan. São Paulo: Iluminuras, Opan, 1989.

PEREIRA, L. M. Mobilidade e processos de territorialização entre os Kaiowá atuais. Revista História em Reflexão, 1(1): 1-33, 2007. Disponível em: <ojs.ufgd.edu.br/index.php/historiaemreflexao/article/viewFile/490/360>. Acesso em: 28 jan. 2013.

PISSOLATO, E. A Duração da Pessoa: mobilidade, parentesco e xamanismo Mbya (Guarani). São Paulo: Editora da Unesp, 2007. 


\section{Migração do Povo Indígena Sateré-Mawé em Dois Contextos Urbanos na Amazônia*}

Entre os fenômenos demográficos relacionados à população indígena que estão a exigir aprofundamento e detalhamento de análise, encontra-se a migração, especialmente a que se dá em direção às cidades. Os processos migratórios constituem fenômenos ainda pouco estudados, embora estejam se tornando cada vez mais frequentes, em decorrência, entre outros fatores, da absorção do indígena nos mercados regionais, dos conflitos por terra e da insuficiente infraestrutura e disponibilidade de serviços essenciais (como os de saúde e educação) nas terras indígenas (Coimbra Jr. G Santos, 2000).

Ainda mais escassos são os estudos demográficos sobre o tema, com base, geralmente, em dados censitários ou coletados em levantamentos específicos de campo, a maioria dos quais realizados a partir do ano 2000. Enquadram-se nessa linha os trabalhos que tratam especificamente da migração indígena ou que a abordam em contexto mais amplo (Coimbra Jr. G Santos, 2000; Pereira G Azevedo, 2004; Pereira, Santos G Azevedo, 2005; Teixeira, 2005; Brasil G Teixeira, 2006; Oliveira, 2008, Teixeira G Sena, 2008; Pinho G Campos, 2008; Dias Jr. et al.; Mainbourg et al., 2008).

Embora constituam fonte obrigatória para o estudo da migração indígena, os dois últimos Censos Demográficos brasileiros (1991 e 2000) apresentam limitações que devem ser tomadas em consideração cada vez que se aborde o assunto. A principal delas é a dificuldade de se trabalhar com pequenos números, especialmente para unidades menores de análise, como municípios ou bairros, áreas urbanas ou rurais, já que a população indígena representa somente 0,4\% do total brasileiro. O caráter amostral das informações levantadas restringe a análise de importantes variáveis apenas aos agrupamentos indígenas mais significativos demograficamente, seja em área urbana seja rural. Assim, por exemplo, para as variáveis relacionadas à migração, a análise deve-se limitar aos dados estaduais, metropolitanos, macro ou microrregionais, ou aos referentes aos municípios com maior concentração de indígenas.

Alguns levantamentos demográficos e participativos de caráter censitário, com quesitos relacionados à migração, têm sido realizados em populações 
indígenas específicas da Amazônia. No estado do Amazonas, a Federação das Organizações Indígenas do Alto Rio Negro (FOIRN) e o Instituto Socioambiental (ISA) realizaram um recenseamento nas terras indígenas do Alto Rio Negro, em 1992, e outro em 2006, na cidade de São Gabriel da Cachoeira, na mesma região (Azevedo, 1994, 2006). Em 2002/2003, um outro recenseamento foi realizado nas comunidades de residência do povo Sateré-Mawé (terra indígena AndiráMarau) e em cidades próximas, todas no estado do Amazonas, numa associação entre instituições governamentais, organizações indígenas e agências das Nações Unidas (Teixeira, 2005). Em 2007, no âmbito de uma pesquisa amostral da Fundação Oswaldo Cruz (Fiocruz), sobre o acesso da população indígena de Manaus ao Sistema Único de Saúde (SUS) - População Indígena da Cidade de Manaus: condições de saúde e SUS -, alguns quesitos sobre migração foram incluídos no formulário do levantamento (Mainbourg et al., 2008). Os Sateré-Mawé, povo indígena ao qual se refere este texto, constituem importante contingente dos imigrantes indígenas de Manaus.

O objetivo deste capítulo é estudar, sob o enfoque demográfico, a migração dos Sateré-Mawé para as cidades próximas da terra indígena Andirá-Marau e para a capital amazonense, com base nas informações obtidas nos dois últimos levantamentos mencionados.

\section{Aspectos metodológicos}

Dois contextos migratórios que abrangem o povo indígena Sateré-Mawé serão enfocados, individual e comparativamente, como forma de se procurar entender a migração indígena para curtas e longas distâncias. Num primeiro momento, serão estudadas algumas características dos fluxos migratórios que, a partir das terras indígenas de origem desse povo, se destinam a quatro cidades localizadas nas proximidades daquelas terras. O estudo utiliza informações quantitativas a respeito da intensidade da migração, da distribuição por sexo e idade dos migrantes, das suas causas e do tempo de residência na cidade de destino. Como tais fatores podem estar associados entre si, as informações são cruzadas para a análise, quando necessário.

Para o a abordagem desse processo migratório com destino a cidades interioranas, serão utilizadas informações obtidas no Diagnóstico Demográfico Participativo de 2002/2003, nas cidades de Parintins, Barreirinha, Maués e Nova Olinda do Norte (Teixeira, 2005). A referida pesquisa teve como entrevistadores professores e estudantes indígenas. Foi aplicada a técnica do tipo bola de neve, em que os próprios entrevistados indicavam outras pessoas e famílias a serem visitadas. Acredita-se que, com algumas exceções, a totalidade dos Sateré-Mawé residentes nessas cidades foi coberta pelo levantamento. Quesitos sobre habitação, 
demografia, saúde, educação, idioma escrito e falado, emprego e renda compuseram o formulário da pesquisa. Os quesitos do componente demográfico contemplaram vários aspectos do processo migratório, como local de nascimento, residências anteriores, condição de nascimento ou não em terra indígena, município e estado de nascimento e de residência anterior, tempo de residência na cidade de moradia atual e motivos da migração. Os quesitos sobre migração destinaram-se a moradores com idade igual ou superior a 10 anos.

Um artigo publicado nos Anais do XVI Encontro Brasileiro de Estudos Populacionais, em 2008, com base em dados levantados naquela pesquisa, aborda os deslocamentos no interior da terra indígena Andirá-Marau para as cidades interioranas próximas (Teixeira G Sena, 2008). É retomado aqui, com as modificações devidas, o referido artigo que trata da migração para aquelas cidades.

Outro contexto migratório estudado refere-se à cidade de Manaus, capital do estado do Amazonas. A migração será também analisada segundo as características já abordadas nas cidades interioranas, vizinhas das terras dos Sateré-Mawé. A análise será complementada com estudos comparativos, de um lado, dos migrantes Sateré-Mawé com os pertencentes a outros povos indígenas moradores da capital e, de outro, dos migrantes Sateré-Mawé de Manaus com os que se destinam àquelas outras cidades.

A análise da migração dos Sateré-Mawé para a cidade de Manaus tem como base quantitativa uma pesquisa amostral realizada pela Fiocruz em 2007 (Mainbourg et al., 2008). Trata-se de um estudo que compara o atendimento prestado pelo SUS em Manaus às populações indígenas e não indígenas. A pesquisa baseia-se em levantamento amostral de 753 indígenas de 47 etnias - quase todas originárias do estado do Amazonas - e 874 não indígenas, tendo como entrevistadores professores e estudantes indígenas do município de Manaus, indicados pelas correspondentes associações de moradores indígenas.

Como subsídio à análise dos dados a respeito do atendimento à saúde dos entrevistados, o formulário da pesquisa de campo incluiu vários quesitos sobre a condição sociodemográfica dos moradores. Da mesma forma que no levantamento sobre a migração em direção a cidades interioranas (Mainbourg et al., 2008), foram entrevistados indígenas com 10 anos ou mais, e os quesitos sobre a migração levantaram informações sobre condição de naturalidade, município e estado de nascimento e de última moradia, tempo de residência no município e motivo da migração.

\section{Localização geográfica da população Sateré-Mawé}

A quase totalidade do território dos Sateré-Mawé é composta pela terra indígena Andirá-Marau, que está situada na divisa dos estados do Amazonas e Pará. 
O seu processo de demarcação foi iniciado em 1978, sendo interrompido por dois anos, período caracterizado por várias ameaças de invasão. Destaca-se, entre elas, o projeto de construção da estrada que liga Maués a Itaituba, que cortaria a terra indígena ao meio, e a prospecção de petróleo protagonizada pela empresa petrolífera francesa Elf-Aquitaine. A demarcação foi finalmente oficializada em 1982 e homologada em 1986 (Teixeira, 2005). Posteriormente, ocorreram penetrações esporádicas de garimpeiros e de posseiros moradores dos limites fronteiriços da terra indígena. Atualmente, o risco de invasão do território Sateré-Mawé está de volta por conta de grileiros ligados ao agronegócio no município de Itaituba (PA), onde se encontram várias aldeias da terra indígena Andirá-Marau.

Uma parcela reduzida do povo Sateré-Mawé reside numa aldeia situada na terra indígena Koatá-Laranjal, do povo Munduruku, no município de Borba (AM), a uma centena de quilômetros do Andirá-Marau. Três famílias de migrantes dessa aldeia moram na cidade de Nova Olinda do Norte, situada no município de mesmo nome, e bastante próxima à referida comunidade.

Em 2003, por ocasião da pesquisa de campo referente ao Diagnóstico Demográfico Participativo de 2002/2003 (Teixeira, 2005), a população Sateré-Mawé que residia em área indígena e nas cidades de Barreirinha, Maués, Parintins Nova Olinda do Norte e Manaus chegava a, aproximadamente, 9 mil habitantes. No Andirá-Marau, havia 91 aldeias distribuídas ao longo dos principais rios e igarapés que cortam a terra dos Sateré-Mawé e onde viviam em exatamente 1.500 domicílios, 7.375 habitantes. A área mais povoada do Andirá-Marau localiza-se ao longo do rio Andirá e seus principais tributários, no município de Barreirinha, em que há 50 aldeias. Segunda área em população, a região banhada pelos rios Marau, Urupadi e Miriti, com 37 aldeias, localiza-se nos municípios de Maués (AM) e Itaituba (PA). Num patamar demográfico mais reduzido está a área do rio Uaicurapá, no município de Parintins, com quatro aldeias. A aldeia situada na terra indígena Koatá-Laranjal tem 31 residências, com 127 moradores (Tabela 1).

Dentre as cidades situadas na vizinhança da área indígena, a mais habitada pelos Sateré-Mawé é Parintins, importante centro urbano do Amazonas e onde se concentram o comércio e os serviços mais dinâmicos do leste do estado. Barreirinha vem em seguida, com pouco mais da metade da população Sateré-Mawé de Parintins. Por sua vez, apenas três domicílios são habitados pelos Sateré-Mawé na cidade de Nova Olinda do Norte, próxima a uma aldeia desse povo situada em terra Munduruku. Essa reduzida população reflete a exiguidade demográfica da aldeia em questão, que tem apenas 127 habitantes.

Em Manaus, capital do estado do Amazonas, vive uma expressiva quantidade de Sateré-Mawé, composta por migrantes, seus filhos e netos. A chegada dos primeiros migrantes à cidade deu-se, provavelmente, à implantação da Zona Franca de Manaus, em 1967, conforme se verá mais adiante. 
Embora difícil de quantificar, observa-se um contingente não negligenciável de Sateré-Mawé em áreas rurais próximas à terra indígena Andirá-Marau. Trata-se de famílias que, apesar de manterem vínculos culturais e sociais com a terra de origem, optaram por viver em suas proximidades. Os dados disponibilizados do Censo Demográfico não permitem distinguir numericamente indígenas moradores das terras indígenas dos que habitam na zona rural, razão pela qual o número de 300 residentes em áreas rurais, mostrados na Tabela 1, resulta de uma estimativa feita pelos autores, a qual teve como parâmetro o total de migrantes residentes nas cidades próximas às terras indígenas e nascidos nas áreas rurais vizinhas.

Tabela 1 - População Sateré-Mawé segundo situação de domicílio em 2002-2003

\begin{tabular}{l|c|c|c}
\hline Local de residência & N. de comunidades & N. de domicílios & População \\
\hline Área indígena & 92 & 1.531 & 7.502 \\
\hline Andirá & 50 & 779 & 3.795 \\
\hline Marau & 4 & 662 & 3.288 \\
\hline Uaicurapá & 1 & 59 & 292 \\
\hline Koatá-Laranjal & - & 31 & 127 \\
\hline Área urbana & - & 228 & 998 \\
\hline Parintins & - & 127 & 512 \\
\hline Barreirinha & - & 50 & 276 \\
\hline Maués & - & 48 & 200 \\
\hline Nova Olinda do Norte & - & 3 & 10 \\
\hline Área rural não indígena & - & - & $300^{*}$ \\
\hline Cidade de Manaus & - & - & $600^{*}$ \\
\hline Total & & & 9.400 \\
\hline
\end{tabular}

* População estimada pelos autores.

Fonte: elaborado pelos autores com base no Diagnóstico Demográfico Participativo de 2002/2003 (Teixeira, 2005).

\section{Considerações sobre a migração indígena para as cidades}

Os elementos básicos de determinação dos deslocamentos da população indígena para as cidades amazônicas no século XX devem ser procurados no contexto histórico em que se deram as transformações sociais e econômicas no Brasil, especialmente a partir dos anos 1950, com consequências nas áreas rurais e indígenas da Amazônia. 
Ocorrendo de forma simultânea ao processo de urbanização, o progresso técnico e o desenvolvimento dos transportes facilitaram a comunicação entre as pessoas e as instituições, promovendo as condições econômicas, operacionais e ideológicas que permitiram a transferência de milhões de brasileiros das áreas rurais para as cidades próximas e, dessas, para as aglomerações urbanas de grande porte, ou diretamente da zona rural para as cidades de médio e grande porte.

Tais transformações passaram, com o tempo, a apresentar reflexos no cotidiano da população indígena. Grande parte dela acabou por migrar para as cidades por não ter legalizada a terra em que vivia, não possuir meios de nela sobreviver, não desfrutar condignamente de serviços sociais básicos, ou simplesmente por ser atraída pela vida urbana (especialmente os jovens). No Censo Demográfico de 2000, mais da metade da população que se declarou indígena vivia no meio urbano. $\mathrm{Na}$ região Norte, a proporção correspondente era de 23\% (IBGE, 2005).

A migração para as cidades próximas das terras indígenas dá-se no âmbito do processo de urbanização no Brasil, o qual tem diminuído de intensidade nas áreas mais desenvolvidas, com tendência a reduzir-se também na região Norte. Manaus constitui o destino preferido dos migrantes do interior do estado, quando se considera o conjunto da população (indígenas e não indígenas). De uma maneira geral, a primeira etapa do processo migratório inicia-se com a mudança da população rural para a área urbana dos municípios próximos. Esse fenômeno ocorre também com a migração indígena, mas há especificidades que diferenciam essa última do processo migratório da população abrangente.

Várias situações podem determinar o movimento migratório dos indígenas em direção aos aglomerados urbanos, as quais, segundo Baines (2001), vão desde aquelas em que os indígenas são expulsos das suas terras, até outras situações em que optam pela vida na cidade, em decorrência da falta de oportunidades de educação e atendimento adequado de saúde nas suas aldeias. O processo ocorre de formas diversas, desde o traslado de grupos familiares para bairros onde já há um contingente grande de índios organizados politicamente, até casos de migração de indivíduos para a cidade em busca de empregos, tratamento de saúde, educação ou um novo estilo de vida (Baines, 2001).

Os condicionantes da migração indígena em direção às cidades têm como aliados importantes o progresso e a universalização dos meios de comunicação de massa, bem como as facilidades crescentes de locomoção na área indígena e, dela, em direção à cidade, considerada, cada vez mais, como referência para a satisfação de necessidades antigas e novas. 


\section{A migração dos Sateré-Mawé: da terra indígena para as cidades próximas}

Cerca de 20\% dos Sateré-Mawé vivem fora das terras indígenas (Tabela 1), seja nas cidades e áreas rurais vizinhas à terra indígena Andirá-Marau, seja em Manaus. Os determinantes desse significativo deslocamento estão relacionados aos contatos cada vez mais intensos com a população não indígena, proporcionados, por sua vez, pelo acesso crescente aos meios de informação e pela relativa facilidade de locomoção. Esses fatores determinantes relacionam-se não apenas com as mudanças que ocorreram e ocorrem na sociedade envolvente, como também com as transformações econômicas, sociais e culturais no interior das comunidades indígenas, tendo como pano de fundo a degradação das condições de subsistência nos territórios onde elas se situam.

Em dissertação de mestrado sobre as condições de vida dos Sateré-Mawé residentes em Manaus, Romano (1982: 7) afirma que a causa determinante da saída desse povo da área indígena foi a desestruturação do seu modo de vida tradicional. Com o objetivo de "trazer elementos para a reflexão sobre os problemas da etnicidade em áreas urbanas", o autor procura descrever as peculiaridades do processo migratório e da qualidade de vida dos Sateré-Mawé, reconstruir a presença simbólica do indígena e apreender os mecanismos de identificação étnica, buscando entender como essa presença incide sobre sua situação.

Mensalmente, os assalariados e aposentados Sateré-Mawé, geralmente acompanhados da família, vão às cidades próximas das aldeias para receber proventos, fazer compras, visitar parentes, consultar o médico etc. Os filhos que estudam nessas cidades mantêm vínculo permanente e intenso com suas famílias, embora alguns acabem não voltando mais à aldeia de origem. Todavia, para todos eles, a terra que deixam continua a referência principal, havendo sempre a perspectiva do retorno.

Nas quatro cidades próximas à área indígena, foram recenseados 998 Sateré-Mawé (478 homens e 525 mulheres), dos quais 678 com 10 anos ou mais. Desses últimos, 570, que serão designados doravante como "migrantes", declararam não ser naturais das cidades em que residiam e constituirão a população a ser estudada.

Como se observa na Tabela 2, para quase $80 \%$ dos migrantes das cidades em foco, o local de nascimento é a terra indígena, mas uma parcela significativa nasceu em áreas rurais próximas àquela área. Um contingente menor declarou ter nascido em outras cidades, especialmente Manaus (12 entrevistados). 
Tabela 2 - Local de nascimento dos migrantes Sateré-Mawé em 2002-2003*

\begin{tabular}{l|c|c}
\hline \multirow{2}{*}{ Local de nascimento } & \multicolumn{2}{|c}{ População migrante } \\
\cline { 2 - 3 } & efetivos & $\%$ \\
\hline Terra indígena & 448 & 78,6 \\
\hline Área rural & 87 & 15,3 \\
\hline Outras cidades & 28 & 4,9 \\
\hline Não sabe/não informou & 7 & 1,2 \\
\hline Total & 570 & 100 \\
\hline
\end{tabular}

* População residente das cidades de Parintins, Barreirinha, Maués e Nova Olinda do Norte Fonte: Teixeira G Sena, 2008.

\section{Estrutura demográfica e motivo da migração}

São os jovens e adolescentes - especialmente os primeiros - que constituem a maioria dos migrantes Sateré-Mawé que residem nas cidades próximas da terra indígena. Mais de dois terços deles (71\%) têm menos de 25 anos de idade. Apesar da queda relativa nas faixas etárias a partir dos 25 anos, a proporção de migrantes nessas idades e, mesmo entre os idosos, ainda é significativa (Gráfico 1). Isso ocorre porque, na realidade, quase todos os moradores Sateré-Mawé com mais de 30 anos são migrantes: de 231 moradores nessa faixa etária, apenas 11 eram naturais daquelas cidades quando foi realizada a pesquisa entre 2002 e 2003.

Gráfico 1 - Distribuição etária da população Sateré-Mawé migrante em área urbana em 2002-20031

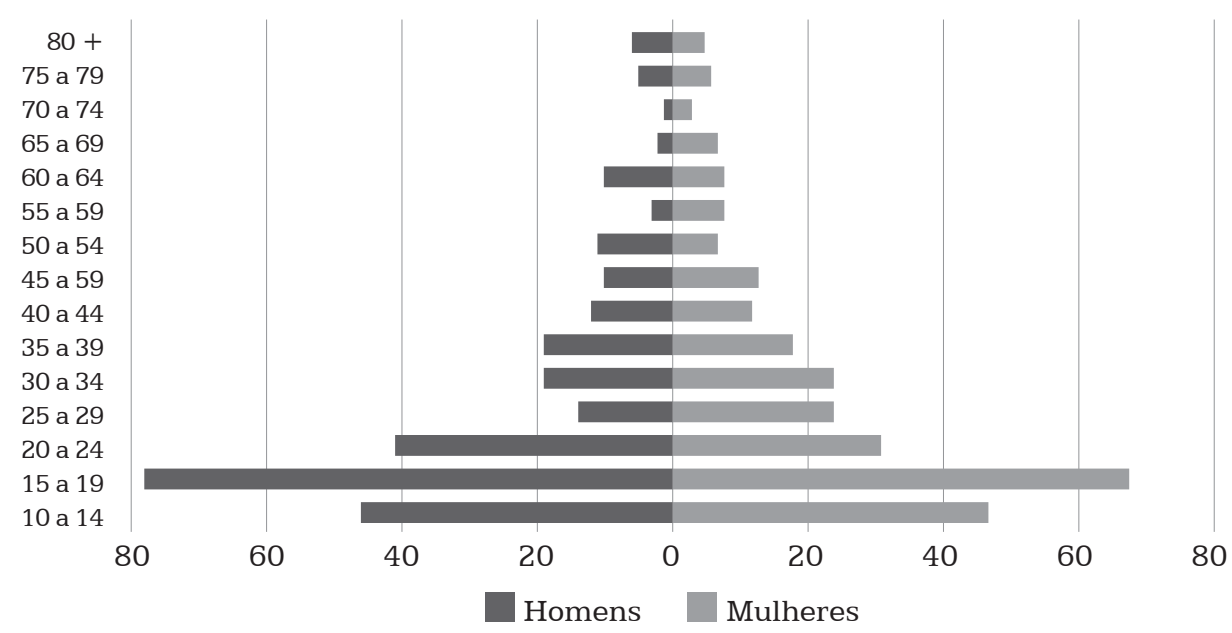

Fonte: Teixeira G Sena, 2008. 
As mulheres constituem uma pequena maioria, relativamente aos homens (51,4\% do total), mas essa superioridade numérica manifesta-se irregularmente entre os grupos etários. Até os 20 anos, os homens são ligeiramente mais numerosos. A partir daí, as mulheres passam a representar, em média, 57\% dos migrantes. Não seria temerário deduzir, a partir da observação do Gráfico 1, que a expressiva participação de adultos e idosos na população Sateré-Mawé migrante pode estar relacionada à supremacia feminina nessas faixas etárias, nesses efetivos populacionais.

Há uma relação entre a distribuição por idade e por sexo dos migrantes Sateré-Mawé e os motivos para o deslocamento para as cidades próximas da terra indígena. As duas justificativas mais citadas nas entrevistas, conforme se observa na Tabela 3, são a busca por melhores condições de educação (49\%) e o acompanhamento dos pais em sua mudança de residência (29\%).

Tabela 3 - Motivos de migração para a cidade, segundo a idade e o sexo do migrante*

\begin{tabular}{l|r|r|r|r|r|r|r|r|r}
\hline \multirow{2}{*}{ Motivos da migração } & \multicolumn{7}{|c}{ Faixa etária } \\
\cline { 2 - 12 } & \multicolumn{2}{|c|}{$10-29$ anos } & \multicolumn{3}{|c}{30 anos e mais } & \multicolumn{3}{c}{ Todas as idades } \\
\cline { 2 - 12 } & Masc. & Fem. & Total & Masc. & Fem. & Total & Masc. & Fem. & Total \\
\hline Transferência de trabalho & 1 & 1 & 2 & 12 & 2 & 14 & 13 & 3 & 16 \\
\hline Procura de trabalho & 1 & 13 & 14 & 6 & 4 & 10 & 7 & 17 & 24 \\
\hline $\begin{array}{l}\text { Procura de melhores condições } \\
\text { de educação }\end{array}$ & 104 & 78 & 182 & 42 & 54 & 96 & 146 & 132 & 278 \\
\hline Acompanhamento dos pais & 69 & 72 & 141 & 10 & 12 & 22 & 79 & 84 & 163 \\
\hline Outros & 6 & 20 & 26 & 26 & 37 & 63 & 32 & 57 & 89 \\
\hline Total & 181 & 184 & 365 & 96 & 109 & 205 & 277 & 293 & 570 \\
\hline
\end{tabular}

* População residente das cidades de Parintins, Barreirinha, Maués e Nova Olinda do Norte

Fonte: elaborado pelos autores com base no Diagnóstico Demográfico Participativo de 2002/2003 (Teixeira, 2005).

Uma parcela substancial dos migrantes indígenas costuma deslocar-se juntamente com a própria família, e isso ocorre - como entre os Sateré-Mawé - para que os mais jovens ingressem nas escolas situadas em área urbana. A migração familiar por motivos educacionais realça a importância que os pais dão à continuidade da escolarização dos filhos, bastante reduzida na terra indígena (na época da pesquisa de campo, apenas uma escola oferecia nível de ensino acima do quarto ano do ensino fundamental).

Os resultados do Diagnóstico Demográfico Participativo de 2002/2003 (Teixeira, 2005) indicam que uma quantidade significativa de jovens Sateré-Mawé 
que migram para estudar o fazem desacompanhados de suas famílias. Hospedam-se em residência de parentes ou, em alguns casos, na Casa do Estudante Indígena, como a que existe na cidade de Maués. Tal situação, para as famílias desses jovens, parece estar relacionada à falta de condições financeiras, às dificuldades de instalação, adaptação e sobrevivência do grupo familiar na cidade, ao apego à terra ancestral ou, ainda, à necessidade objetiva da família de continuar morando na terra indígena, condicionada por fatores econômicos, sociais ou políticos.

Os dados levantados indicam uma diferenciação entre homens e mulheres Sateré-Mawé em relação aos motivos de migrar. A transferência de trabalho, por exemplo, mesmo sendo citada por poucas pessoas, é uma característica basicamente masculina. Entre os 28 funcionários públicos indígenas residentes nessas cidades (em igual número de homens e mulheres), há seis migrantes, todos homens, que se mudaram porque foram transferidos. Nenhuma mulher do serviço público o fez pela mesma razão. Entretanto, a migração motivada pela procura de trabalho (citada por apenas $4 \%$ dos migrantes) constitui uma prerrogativa majoritária das mulheres jovens (entre10 e 29 anos). Entre as migrantes dessa faixa etária, dez alegaram a procura de trabalho como motivo do deslocamento, o que não foi citado por nenhum homem dessa mesma faixa. A partir de 30 anos de idade, há igualdade numérica para homens e mulheres que migraram por esse motivo. ${ }^{2}$

Mostra-se diferente o quadro quando se considera a migração motivada pela procura de melhores condições de educação. Até os 29 anos de idade, são os homens que constituem maioria dos que declararam essa causa. Eles são 104,

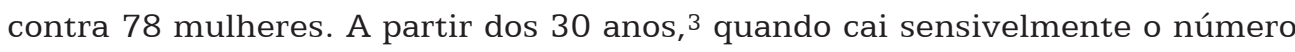
de migrantes que se mudaram para a cidade à procura de educação escolar, o número de mulheres que indicaram esse motivo passa a ser superior ao dos homens (Tabela 3). Não há evidências que expliquem satisfatoriamente essa diferença, mas é provável que, na concepção da família, o rapaz se adapte mais facilmente que a jovem a um ambiente desconhecido e adverso, em muitos sentidos. Talvez, justamente por não terem a oportunidade de se mudar para a cidade quando jovens, muitas mulheres o fazem mais tarde e em maior número que os homens.

Os dados disponíveis mostram que as causas da migração dos Sateré-Mawé para as cidades, por idade e sexo dos migrantes, não se modificaram substancialmente no decorrer do tempo. Nos dez anos anteriores à pesquisa de campo, elas mantiveram-se praticamente as mesmas que as verificadas em períodos anteriores.

Mesmo para os mais idosos (50 anos ou mais), os motivos da migração não parecem diferenciar-se significativamente dos declarados pelos demais. No entanto, a quantidade reduzida de migrantes idosos não permite avançar hipóteses confiáveis das causas que os levaram a procurar a vida urbana.

Em especial, os movimentos migratórios causados pela procura de melhores condições de ensino parecem manter, no conjunto dos motivos do deslocamento dos Sateré-Mawé, a mesma relevância no decorrer do tempo. 
Tabela 4 - Tempo de moradia dos migrantes em 2002-2003*

\begin{tabular}{l|c|c|c|c|c}
\hline \multirow{2}{*}{ Tempo de residência } & \multicolumn{5}{|c}{ Cidade de residência atual } \\
\cline { 2 - 7 } & Barreirinha & Maués & $\begin{array}{c}\text { Nova Olinda } \\
\text { do Norte }\end{array}$ & Parintins & Total \\
\hline Menos de 1 ano & 5,6 & 24,6 & 14,3 & 9,5 & 11,9 \\
\hline De 1 a 4 anos & 42,5 & 41,8 & 0 & 25 & 33,2 \\
\hline De 5 a 9 anos & 24,4 & 21,6 & 42,9 & 22,6 & 23,1 \\
\hline 10 anos ou mais & 27,5 & 11,9 & 42,9 & 42,9 & 31,8 \\
\hline Total & 100 & 100 & 100 & 100 & 100 \\
\hline Número de migrantes & 160 & 130 & 7 & 273 & 570 \\
\hline $\begin{array}{l}\text { População com 10 anos } \\
\text { ou mais }\end{array}$ & 190 & 145 & 7 & 346 & 688 \\
\hline
\end{tabular}

* População residente das cidades de Parintins, Barreirinha, Maués e Nova Olinda do Norte Fonte: elaborado pelos autores com base no Diagnóstico Demográfico Participativo de 2002/2003 (Teixeira, 2005).

\section{Tempo de residência nas cidades}

As cidades de Parintins e Barreirinha, conforme apresentado na Tabela 4, são os destinos da maior parte dos migrantes nascidos na terra indígena Andirá-Marau e da quase totalidade dos nascidos especificamente na área do Andirá, um dos três componentes daquela terra indígena (as outras áreas são o Marau e o Uaicurapá). Isso ocorre em virtude da pouca distância que separa o rio Andirá daquelas duas cidades. Já a cidade de Maués, sede do município banhado pelo rio Marau, constitui a referência geográfica urbana principal para os Sateré-Mawé residentes na bacia desse rio.

É relativamente recente a migração para as cidades próximas das terras habitadas pelos Sateré-Mawé. De fato, em 2003, 67,2\% dos migrantes moravam nessas cidades havia menos de dez anos e, desses, dois terços tinham menos de cinco anos de residência. Segundo os dados levantados, o destino anterior dos fluxos migratórios concentrava-se quase exclusivamente em Barreirinha e Parintins, tendo sido depois redirecionado, em grande parte, para Maués. Excetuando-se Nova Olinda do Norte (que tem um total de apenas dez moradores Sateré-Mawé), Maués é a cidade com a maior proporção (92\%) de mwigrantes na população com 10 anos ou mais de idade, isto é, a população Sateré-Mawé que ali reside - com exceção das crianças - é constituída praticamente por migrantes.

Com a devida cautela, pode-se inferir que a migração em maior escala dos Sateré-Mawé em direção às cidades próximas às terras indígenas se tenha iniciado aproximadamente trinta anos antes da realização do Diagnóstico Demográfico 
Participativo de 2002/2003 (Teixeira, 2005). Isso porque $90 \%$ dos naturais dessas cidades tinham idade superior a 30 anos, ${ }^{4}$ isto é, nasceram a partir do início da década de 1970, o que sugere que os migrantes (pais dos naturais) mais antigos teriam, em sua grande maioria, pouco mais de trinta anos de moradia.

Além de indicar uma perda de população da área do Marau para a cidade de Maués, os dados disponíveis (Tabela 5) mostram uma perda ainda maior na área do Andirá, devido à migração para Parintins e Barreirinha, mas não apenas para essas duas cidades. Os Sateré-Mawé do Andirá povoaram a área do rio Uaicurapá e a aldeia Sateré-Mawé situada no Koatá-Laranjal, além de se terem estabelecido, em grande número, em Manaus. Os moradores das cidades vizinhas e das áreas do Uaicurapá e do Koatá-Laranjal receberam 556 migrantes do Andirá e 291 do Marau. Apenas de Ponta Alegre, aldeia do Andirá, saíram 69 dos 160 imigrantes de Barreirinha e 168 dos 296 de Parintins. A soma desses dois valores representava $60 \%$ dos 397 moradores da referida comunidade em 2003. Caso se considere apenas a população com idades entre 10 a 49 anos, o número de migrantes que deixou Ponta Alegre será bem superior à respectiva população (237 migrantes para 199 moradores na faixa etária).

Tabela 5 - Área indígena de nascimento por cidade de residência atual*

\begin{tabular}{l|r|r|r|r|r}
\hline \multirow{2}{*}{ Cidade de residência } & \multicolumn{5}{|c}{ Área indígena de nascimento } \\
\cline { 2 - 6 } & Andirá & Maraus & Outras & Não sabe & Total \\
\hline Barreirinha & 95 & - & - & - & 95 \\
\hline Maués & 9 & 105 & 3 & - & 117 \\
\hline Nova Olinda do Norte & 2 & - & - & - & 2 \\
\hline Parintins & 223 & 5 & 4 & 1 & 232 \\
\hline Total & 329 & 110 & 7 & 1 & 446 \\
\hline
\end{tabular}

* População residente das cidades de Parintins, Barreirinha, Maués e Nova Olinda do Norte Obs. Os migrantes não contabilizados na tabela são originários de outros locais, em especial da área rural adjacente à terra indígena Andirá-Marau.

Fonte: elaborado pelos autores com base no Diagnóstico Demográfico Participativo de 2002/2003 (Teixeira, 2005).

\section{Migração para Manaus}

\section{Contextualização do processo migratório}

Localizada no coração do estado do Amazonas, a cidade de Manaus constitui a principal referência urbana para a maioria dos migrantes - indígenas e não indígenas - do estado, especificamente para os primeiros, por ter o Amazonas o 
maior contingente de indígenas do país. Manaus, cidade cuja população superou 1.600.000 habitantes em 2007 (IBGE, 2007), tornou-se, a partir de 1970, quando tinha menos de 300 mil habitantes, o destino escolhido por expressivos fluxos de migrantes do interior de outros estados da federação, especialmente das regiões Norte e Nordeste. Contando com um parque industrial moderno e dinâmico, fruto dos subsídios da Zona Franca de Manaus, apresenta intensa atividade no comércio e nos serviços, cujos empregos são disputados por naturais e migrantes. Sua população indígena, de quase 8 mil habitantes em 2000 e estimada em $2009^{5}$ em pouco mais de 10 mil, é composta, em grande maioria, por migrantes provenientes das terras indígenas do estado do Amazonas e por seus filhos.

Foi nas décadas imediatamente anteriores a 1990 que chegou a Manaus a maioria dos migrantes da cidade. Os anos 1970 e 1980 presenciaram um crescimento populacional extraordinário e inédito, com uma média anual de aproximadamente $6,5 \%$.

Remonta a vários séculos o movimento migratório indígena em direção a Manaus, o qual se intensificou durante o ciclo da borracha (séculos XIX e XX). No entanto, foi a partir da criação da Superintendência da Zona Franca de Manaus (Suframa) que a migração se tornou um movimento contínuo. Segundo depoimento de um líder indígena do Alto Rio Negro (AM), a propaganda governamental da época apregoava que os indígenas poderiam ter uma vida melhor trabalhando na cidade (Barretto, 2002).

Os indígenas residentes em Manaus provêm de todo o interior do estado e representam a grande maioria das etnias amazonenses. Não há dados globais confiáveis a respeito da repartição étnica daqueles que migraram para Manaus, mas sabe-se que eles são originários das terras indígenas de maior concentração populacional, entre as quais sobressaem as que se situam no Alto Rio Negro e no Alto Solimões. O levantamento estatístico que doravante abordaremos indica que, entre as etnias mais presentes na cidade, encontram-se os Ticuna e Cokama, do Alto Solimões, os Tucano, Baré, Dessana e Tariano, do Alto Rio Negro, e os SateréMawé, do Médio Amazonas.

De uma forma geral, a dimensão e a intensidade dos fluxos migratórios de cada etnia para Manaus dependem tanto de seu volume populacional nas áreas de origem como da quantidade de moradores da mesma etnia que reside na capital amazonense. Não seria exagero afirmar que, quanto maior a rede social constituída por um determinado povo indígena na cidade, maior a propensão dos membros desse povo nas áreas indígenas a migrar com destino a Manaus (Mainbourg et al., 2008).

Conforme mencionado, não há indicação segura da quantidade de SateréMawé ou de membros de outras etnias em Manaus. Sua estimação é dificultada pela falta de parâmetros confiáveis para os cálculos correspondentes. Romano (1982) chegou a contabilizar 88 indígenas pertencentes a esse povo na cidade. De forma 
muito aproximada, estima-se que seu número possa ser situado entre 600 e 700 pessoas em 2008, admitindo-se a hipótese que os Sateré-Mawé têm, sobre a população indígena da cidade, o mesmo peso que seus efetivos estaduais tinham em 2000 sobre o total de indígenas do estado do Amazonas (aproximadamente 9 mil Sateré-Mawé, num total de 113 mil indígenas no estado) (Tabela 6). ${ }^{6}$

Tabela 6 - Número de indígenas entrevistados por etnia em 2007, na cidade de Manaus

\begin{tabular}{l|c}
\hline Povo indígena & Entrevistados \\
\hline Sateré-Mawé & 164 \\
\hline Tukano & 125 \\
\hline Tikuna & 76 \\
\hline Baré & 70 \\
\hline Dessana & 44 \\
\hline Cokama & 46 \\
\hline Tariano & 38 \\
\hline Apurinã & 27 \\
\hline Mura & 24 \\
\hline Outros & 144 \\
\hline Total & 753 \\
\hline
\end{tabular}

Fonte: Mainbourg et al., 2008.

Com uma distribuição etária mais jovem que a da população indígena urbana do Brasil em 2000, os indígenas de Manaus apresentam uma repartição por sexo marcadamente favorável às mulheres. Essa característica é verificada em quase todos os grupos etários, principalmente nas idades economicamente ativas, e está relacionada à maioria nitidamente feminina nos fluxos migratórios para a cidade (Mainbourg et al., 2008). A repartição por sexo e idade dos Sateré-Mawé assemelha-se à dos demais povos indígenas numericamente importantes na cidade.

Quanto à migração indígena, é necessário ressaltar inicialmente sua importância na composição da população indígena de Manaus. Dois terços dos entrevistados com idade igual ou superior a 10 anos não são naturais da cidade. Proporcionalmente, eles superam em muito os migrantes não indígenas, que correspondem à metade dos entrevistados não indígenas.

Quase 77\% dos migrantes indígenas entrevistados nasceram em terra indígena. O restante nasceu em áreas urbanas ou rurais situadas na proximidade das terras indígenas de procedência ou - em poucos casos - em outros locais (outros municípios amazonenses ou outros estados). 
A proporção de migrantes na população indígena entrevistada em Manaus varia segundo a etnia. Entre as mais representadas na cidade, os Tukano e os Cokama constituem as maiores proporções de migrantes (80\%). Os SateréMawé apresentam a menor proporção (53\%) no total de moradores da etnia, correspondendo a 80 entre os 151 residentes entrevistados sobre migração. Esse será o total de migrantes adotado como base para as considerações que se seguirão. Apesar da pequena quantidade, poderão ser levantados elementos interessantes para a análise, especialmente na comparação de algumas características dos migrantes de Manaus, distante das terras indígenas dos Sateré-Mawé, com os de cidades próximas àquelas terras.

\section{Características demográficas e motivos da migração}

Conforme visto anteriormente, há uma maioria feminina entre os indígenas de Manaus, o que deve estar relacionado à maior migração das mulheres. De fato, elas são mais numerosas que os homens entre os migrantes indígenas, representando 261 dos 452 entrevistados (58\%). Como os não migrantes indígenas repartem-se em proporções quase iguais de homens e mulheres, o diferencial por sexo, no total da população, fica sendo determinado pela superioridade feminina entre os migrantes (Tabela 7).

Os migrantes Sateré-Mawé apresentam uma participação feminina ainda mais elevada $(65 \%)^{7}$ em relação à população total indígena de Manaus. Assim como para o conjunto dos povos indígenas da cidade, a diferença quantitativa a favor das mulheres entre os Sateré-Mawé migrantes é quase idêntica à do total dos moradores dessa etnia. Isto equivale a afirmar que os números de homens e mulheres naturais de Manaus (não migrantes) são quase iguais (34 e 30 pessoas, respectivamente). Em consequência, a maioria feminina na população Sateré-Mawé deve-se quase inteiramente à forte migração feminina para a cidade.

Tabela 7 - Número de migrantes Sateré-Mawé e de todas as etnias da amostra, segundo a condição de migração em 2007, na cidade de Manaus

\begin{tabular}{l|c|c|c|c|c|c}
\hline \multirow{2}{*}{$\begin{array}{l}\text { Condição de } \\
\text { naturalidade }\end{array}$} & \multicolumn{3}{|c|}{ Sateré-Mawé } & \multicolumn{3}{c}{ Todas as etnias } \\
\cline { 2 - 7 } & Homens & Mulheres & Total & Homens & Mulheres & Total \\
\hline Não migrantes & 34 & 38 & 72 & 128 & 132 & 260 \\
\hline Migrantes & 28 & 52 & 80 & 191 & 261 & 452 \\
\hline Total & 62 & 90 & 152 & 319 & 393 & 712 \\
\hline
\end{tabular}

Fonte: elaborado pelos autores com base em dados obtidos em levantamento de campo descrito em Mainbourg et al., 2008. 
Quando se analisam conjuntamente o sexo e a idade dos migrantes SateréMawé em Manaus (Tabela 8), observa-se uma situação distinta da observada para as cidades próximas à terra indígena Andirá-Marau, como já se retratou neste capítulo. De um lado, a proporção de mulheres entre os migrantes de Manaus é superior aos $51,4 \%$ encontrados nas cidades mencionadas. De outro, a superioridade feminina não varia significativamente nos grandes grupos etários (0-14, 15-59, 60 anos e mais) na capital amazonense, contrariamente ao observado nas demais cidades, onde a distribuição etária desigual entre homens e mulheres estaria a indicar causas distintas para a migração de adolescentes, jovens e adultos segundo o sexo.

Tabela 8 - População Sateré-Mawé por idade e sexo, segundo a condição de migração em 2007, na cidade de Manaus

\begin{tabular}{l|c|c|c|c|c|c|c|c}
\hline \multirow{2}{*}{$\begin{array}{l}\text { Condição de } \\
\text { migração }\end{array}$} & \multicolumn{2}{|c|}{\begin{tabular}{c} 
10-19 anos \\
\cline { 2 - 9 }
\end{tabular}} & \multicolumn{2}{|c|}{$20-29$ anos } & \multicolumn{2}{c|}{$\begin{array}{c}30 \text { anos e } \\
\text { mais }\end{array}$} & \multicolumn{3}{c}{ Total } \\
\hline Masc. & Fem. & Masc. & Fem. & Masc. & Fem. & Masc. & Fem. \\
\hline Não migrantes & 5 & 9 & 8 & 12 & 15 & 31 & 28 & 52 \\
\hline Migrantes & 13 & 10 & 21 & 28 & 0 & 0 & 34 & 38 \\
\hline Total & 18 & 19 & 29 & 40 & 15 & 31 & 62 & 90 \\
\hline
\end{tabular}

Fonte: elaborado pelos autores com base em dados obtidos em levantamento de campo descrito em Mainbourg et al., 2008.

Em média, os migrantes Sateré-Mawé de Manaus têm idade mais elevada do que os que se deslocaram para as cidades interioranas estudadas. São 57,5\% os de 30 anos e mais entre os primeiros e apenas $36 \%$ entre os últimos. Ao contrário do que ocorre naquelas outras cidades, em que um de cada cinco migrantes tem menos de 15 anos de idade, a proporção em Manaus desses adolescentes é de apenas um para 12. Os migrantes da capital amazonense com 10 a 19 anos de idade representam menos de $20 \%$ do total, ao passo que as cidades próximas à área indígena têm mais que o dobro dessa cifra.

Provavelmente, a razão dessa diferença é que Manaus estaria atraindo menos migrantes Sateré-Mawé adolescentes e jovens que desejam continuar os estudos, permanecendo a maioria desse contingente nas cidades próximas às terras indígenas, usufruindo, ali, da assistência contínua dos pais que mensalmente vão receber salários e aposentadoria. Essa relação administrativa da área indígena com as cidades daria às famílias, em contrapartida, a segurança de um contato permanente com os filhos. Tais condições, evidentemente, não se repetem para Manaus, local em que os migrantes Sateré-Mawé não mantêm tal tipo de relação com a terra natal, pois o acesso dispendioso não permite viagens amiúde num ou noutro sentido.

Assim, diferentemente do que ocorre nas cidades vizinhas da terra indígena Andirá-Marau (Tabela 3), já examinada, a migração por motivos educacionais 
parece ser irrisória em Manaus. Pouco mais de 10\% dos migrantes Sateré-Mawé da cidade declararam a busca de oportunidades educacionais como razão para o deslocamento. Naquelas outras cidades, esse motivo era citado por metade (49\%) dos imigrantes. A procura de trabalho foi pouco mencionada pelos Sateré-Mawé nas referidas cidades ( $4 \%$ dos migrantes), mas constitui a principal causa dos deslocamentos para Manaus, tendo sido referida por 38\% dos migrantes da capital amazonense. É interessante mencionar que os 80 migrantes Tukano da amostra de Manaus (mesmo quantidade dos Sateré-Mawé) declararam igualmente a procura de trabalho e os motivos educacionais como causas da migração, citadas, cada uma, por $31 \%$ dos entrevistados.

De forma também diferente do que ocorre com os migrantes das cidades próximas da terra indígena Andirá-Marau, em que a proporção de mulheres em relação ao total de migrantes variava com a faixa etária, em Manaus, as mulheres migrantes Sateré-Mawé são numericamente superiores aos homens em praticamente todas as faixas etárias, com pequenas exceções sem significância estatística.

\section{Tempo de residência dos migrantes}

Uma forma de melhor compreender a distribuição etária dos migrantes Sateré-Mawé e algumas determinações de seu deslocamento é o exame do tempo de migração, indicado, no caso presente, pelos anos de residência em Manaus.

Assim como o que ocorre para os não indígenas, o tempo de residência de um migrante indígena no local de destino depende de vários fatores: a conjuntura econômica, social ou política à época da migração, o motivo da migração, a idade e o sexo do migrante, a distância entre a área de origem e a de destino, o alcance dos meios de comunicação, as condições de vida dos parentes no local de destino e outros. Conforme já comentado, as migrações indígenas com destino a Manaus, em seu período mais intenso - a partir dos anos 1970 -, ocorreram no âmbito dos intensos fluxos migratórios estimulados pelas oportunidades de emprego criadas com a implantação da Zona Franca de Manaus.

As informações levantadas na pesquisa da Fiocruz realizada em Manaus em 2007 indicam que 40\% dos migrantes indígenas residiam na cidade desde pelo menos duas décadas antes do ano do levantamento de campo. A proporção eleva-se a $70 \%$ quando se consideram os migrantes com dez anos ou mais de residência, isto é, que chegaram a Manaus antes de 1997. Os 30\% restantes migraram a partir desse último ano.

Não há diferença notável entre os Sateré-Mawé e o conjunto dos demais povos indígenas em relação ao tempo de residência na cidade. A quase equivalência mantém-se quando se incorporam o sexo e a idade na análise. Tais constatações indicariam uma independência do processo migratório em relação à etnia ao se consi- 
derarem essas variáveis, ou seja, os diferentes povos indígenas - pelo menos os mais representativos na amostra estudada - mostram comportamento comum (segundo sexo e idade) em relação à tendência migratória nas últimas quatro décadas.

Há, no entanto, uma diferença marcante entre o tempo de migração dos Sateré-Mawé em Manaus e o correspondente nas cidades que têm servido como referência para este estudo. Se, como afirmado, cerca de 70\% dos migrantes SateréMawé de Manaus residiam na cidade antes de 1997, o mesmo não ocorre com os residentes dessa etnia no interior do estado. Conforme indicado na seção referente à migração dos Sateré-Mawé em áreas urbanas próximas à sua terra indígena, no ano de 2003, 8 as cidades de Barreirinha, Parintins, Maués e Nova Olinda do Norte apresentavam, em seu conjunto, apenas 31\% de migrantes Sateré-Mawé com dez anos ou mais de residência. Em Maués, o percentual respectivo não passava dos $12 \%$.

Há duas possibilidades de explicação para essa diferença expressiva. A primeira é que a migração de Manaus é mais antiga, pelo menos no que se refere ao volume migratório em cada época. Como foi visto, o início da migração mais acentuada - embora ainda reduzida - para as cidades citadas data de aproximadamente trinta anos antes de 2003, talvez um pouco mais recente que a referente a Manaus. Todavia, na capital, pode-se deduzir - como será feito adiante - que os fluxos migratórios dos Sateré-Mawé nos anos 1970 foram bem mais intensos que os verificados naquelas cidades do interior. Outra forma de explicar a maior atualidade dos deslocamentos para cidades próximas às terras dos Sateré-Mawé estaria na elevada proporção de migrantes recentes (menos de dez anos de moradia) naquelas cidades. De fato, eles representavam $70 \%$ do total de migrantes em 2003, tendo um peso, portanto, muito maior do que os $30 \%$ contabilizados em Manaus quatro anos depois.

Um dos meios para se identificar o início - ou a intensificação - do processo migratório de um agrupamento populacional para um determinado local é a distribuição etária dos não migrantes nesse espaço. Se um morador não migrante é filho de um pai migrante, o ano de mudança do pai para o local de moradia atual é obrigatoriamente anterior ao do nascimento do filho. A queda abrupta desses efetivos a partir de uma determinada idade indicaria uma redução - também abrupta - da migração (dos pais) em épocas imediatamente anteriores às datas de nascimentos dos filhos. ${ }^{9}$ É o que ocorreu, por exemplo, nas cidades vizinhas às terras dos Sateré-Mawé, onde foi visto que a migração em maior escala dos Sateré-Mawé teria começado aproximadamente trinta anos antes da realização do Diagnóstico Demográfico Participativo de 2002/2003, isto é, por volta do início dos anos 1970. Isso porque praticamente não havia moradores naturais daquelas cidades com idade superior a 30 anos. No caso de Manaus, em 2007, para 221 indígenas não migrantes (todas as etnias), havia 16 com idade entre 30 e 39 anos e apenas dois com 40 ou mais anos, indicando que, na amostra estudada, havia um número irrisório 
de indígenas que chegaram a Manaus mais de 40 anos antes de 2007. Não seria de se descartar, pois, a influência da implantação da Zona Franca de Manaus, em 1967, sobre a intensificação da migração indígena para a cidade, confirmando o depoimento, já citado, de um líder indígena do estado do Amazonas (Barretto, 2002).

\section{Considerações finais}

A migração indígena para as áreas urbanas da Amazônia e, em particular, para o estado do Amazonas, tem acompanhado o processo migratório da população regional como um todo na segunda metade do século XX, em especial o que se deu com a implementação dos grandes projetos de ocupação territorial na segunda metade dos anos 1960. No caso específico da migração para Manaus, sua intensificação teria ocorrido a partir da implementação da Zona Franca, em 1967. Todavia, há indícios de que, nessa época, já se avolumava o deslocamento dos territórios indígenas para as cidades próximas a eles.

Data também aproximadamente da mesma época o início dos movimentos migratórios do povo Sateré-Mawé, tanto para Manaus quanto para cidades próximas à área indígena. Os dados obtidos em dois levantamentos de campo realizados em 2002 e 2003 (terras indígenas Andirá-Marau e Koatá-Laranjal e cidades vizinhas) e em 2007 (Manaus) permitem esboçar algumas características demográficas e sociais desses deslocamentos e traçar comparações entre o processo migratório para um e outro destino.

Em suas características gerais, a migração dos Sateré-Mawé - povo indígena do leste amazonense - para Manaus não difere essencialmente da que se verifica para as demais etnias do estado. Entre as exceções no campo demográfico, está a maior participação feminina na migração dos Sateré-Mawé.

Os motivos da migração são basicamente os mesmos, com destaque para a procura de trabalho e de melhores condições de educação. No entanto, a proporção de entrevistados que indica um ou outro motivo pode variar. Como exemplo, entre os Sateré-Mawé de Manaus, são mais numerosos os migrantes que apontam a procura de trabalho como causa da migração, ao passo que, entre os Tukano, os dois motivos são declarados pelo mesmo número de entrevistados.

Procura de trabalho e busca de melhores condições de ensino são também os principais motivos da migração dos Sateré-Mawé que saem de suas terras em direção às cidades próximas. Em Manaus, as duas causas caminham em direção oposta. Se, nas cidades do interior, a educação é declarada como o principal motivo para a migração, e a procura de trabalho apresenta importância apenas marginal, em Manaus, a procura de trabalho é a mais citada, e a educação, embora não se mostre de todo irrelevante, é referida por um número significativamente menor de migrantes. 
Provavelmente relacionada à situação descrita está a menor juventude da população Sateré-Mawé que se dirige a Manaus. A razão disso poderia ser buscada na atração menor exercida por Manaus sobre os estudantes jovens, os quais tenderiam a migrar para cidades próximas, onde podem usufruir da assistência e do apoio contínuos dos pais, que mensalmente vão receber salários e aposentadoria. Vale acrescentar ainda o fato de que a Universidade Federal do Amazonas e a Universidade do Estado do Amazonas criaram campi avançados em cidades do interior, alguns próximos a áreas indígenas, como Parintins e Maués.

Distintamente do que ocorre com os migrantes Sateré-Mawé das cidades interioranas em foco, em que a participação feminina é apenas um pouco superior à dos homens, em Manaus, as mulheres são mais de dois terços do total de migrantes. Naquelas cidades, apesar dessa reduzida maioria feminina, a acentuada variabilidade na quantidade de homens e mulheres, quando se considera a idade, permitiu levantar a hipótese de causas diferentes para a migração de adolescentes, jovens e adultos segundo o sexo. O mesmo não pôde ser confirmado para o caso de Manaus, já que, apesar da ampla superioridade numérica das mulheres na população migrante, não há uma variação significativa em cada um dos grandes grupos etários (0-14, 15-59, 60 anos e mais), o que se poderia dever ao tamanho reduzido da amostra utilizada na obtenção das informações referentes à migração dos Sateré-Mawé.

* O conteúdo deste capítulo foi publicado originalmente no periódico Caderno CRH (Teixeira, Mainbourg G Brasil, 2009) e aqui reproduzido com a devida permissão. Os organizadores da coletânea agradecem a Caio Bibiani pelo trabalho de adequação do texto, tabelas e figuras da publicação original no formato artigo para a presente versão.

1 Na pirâmide etária, a queda brusca do número de mulheres migrantes entre as idades 20-24 e 25-29 anos deve-se, provavelmente, a uma flutuação aleatória dos dados, ocasionada pela amostra relativamente reduzida de migrantes (260) com 20 anos e mais de idade.

2 No total, 25 indígenas (18 mulheres e sete homens) declararam ter migrado à procura de trabalho.

3 Na Tabela 3, o menor número de migrantes com 30 anos em busca de melhores condições de educação não significa ser esse motivo menos importante para os migrantes mais velhos, mas apenas reflete seu menor contingente demográfico (205) em relação aos jovens (375 com menos de 30 anos de idade).

4 Dos 108 moradores com 10 anos ou mais nascidos nas quatro cidades em estudo, apenas 11 tinham idade superior a 30 anos, sendo dois, em média, por grupo quinquenal, até os 50 anos, e três somente a partir daí. 
5 Ano da publicação da primeira versão deste capítulo.

6 A população Sateré-Mawé em 2000 pode ser estimada como uma retroprojeção dos efetivos contabilizados no Diagnóstico Demográfico Participativo de 2002/2003, listados anteriormente na Tabela 1 (8.500 nas terras indígenas e cidades vizinhas e 500 a 600 em Manaus).

7 A diferença de 7\% entre o número de mulheres Sateré-Mawé e o total de mulheres migrantes deve ser tomada com cautela, em virtude da dimensão reduzida da amostra de migrantes Sateré-Mawé entrevistados (80 moradores).

8 Ano de realização do no Diagnóstico Demográfico Participativo de 2002/2003 citado.

9 Supõe-se, neste estudo, que a quase totalidade dos pais migrantes tenham tido filhos que nasceram na cidade de residência e que não haja mortalidade entre os pais migrantes.

\section{Referências}

AZEVEDO, M. M. Demografia dos povos indígenas do Alto Rio Negro. Revista Brasileira de Estudos de População, 11: 235-244, 1994.

AZEVEDO, M. M. Urbanização e migração na cidade de São Gabriel da Cachoeira, Amazonas. In: ENCONTRO NACIONAL DE ESTUDOS POPULACIONAIS, 15, 2006, Caxambu. Anais.. Campinas: Abep, 2006.

BAINES, S. G. As chamadas "aldeias urbanas" ou índios na cidade. Revista Brasil Indígena, $1(7), 2001$.

BARRETTO, R. Fiocruz conclui pesquisa sobre a saúde dos índios urbanos em Manaus (AM), 2002. Disponível em: <www.socioambiental.org.br>. Acesso em: 31 dez. 2008.

BRASIL, M. G TEIXEIRA, P. Migração dos povos indígenas e os Censos Demográficos de 1991 e 2000: o caso das capitais estaduais. In: ENCONTRO NACIONAL DE ESTUDOS POPULACIONAIS, 15, 2006, Caxambu. Anais... Campinas: Abep, 2006.

COIMBRA JR., C. E. A. G SANTOS, R. V. Saúde, minorias e desigualdade: algumas teias de inter-relações, com ênfase nos povos indígenas no Brasil. Ciência G Saúde Coletiva, 5(1): 531-546, 2000 .

DIAS JR., C. S. et al. Crescimento da população indígena em Minas Gerais: uma análise da influência da dinâmica demográfica e reclassificação racial a partir dos dados censitários de 1991/2000. In: ENCONTRO NACIONAL DE ESTUDOS POPULACIONAIS,16, 2008, Caxambu. Anais... Campinas: Abep, 2008.

INSTITUTO BRASILEIRO DE GEOGRAFIA E ESTATÍSTICA(IBGE). Tendências Demográficas: uma análise dos indígenas com base nos resultados da amostra dos Censos Demográficos 1991 e 2000. Rio de Janeiro: IBGE, 2005. 
INSTITUTO BRASILEIRO DE GEOGRAFIA E ESTATÍSTICA(IBGE). Contagem de população de 2007. Disponível em: <www.ibge.gov.br/estatisticas/sociais/populacao/9065-contagem-da-populacao.html?t=resultados $>$. Acesso em: 13. mar. 2009.

MAINBOURG, E. M. et al. População indígena da cidade de Manaus: demografia e SUS. In: ALMEIDA, A. W. B. G SANTOS, G. S. S. (Orgs.). Estigmatização e Território: mapeamento situacional dos indígenas em Manaus. Manaus: Editora Universidade Federal do Amazonas, 2008.

OLIVEIRA, T. P. P. O crescimento da presença indígena nos Censos nacionais 1991-2000: uma análise da região Nordeste. In: ENCONTRO NACIONAL DE ESTUDOS POPULACIONAIS, 16, 2008, Caxambu. Anais... Campinas: Abep, 2008.

PEREIRA, N. O. M. G AZEVEDO, M. M. Os povos indígenas e os censos do IBGE: uma experiência brasileira. In: CONGRESSO INTERNACIONAL DA ASSOCIAÇÃO LATINO-AMERICANA DE POPULAÇÃO, 1, 2004. Caxambu. Anais... Caxambu: Alap, 2004.

PEREIRA, N. O. M.; SANTOS, R. V. G AZEVEDO, M. M. Perfil demográfico e socioeconômico das pessoas que se autodeclararam "indígenas" nos Censos Demográficos de 1991 e 2000. In: PAGliARO, H.; AZEVEDO, M. M. G SANTOS, R. V. (Orgs.). Demografia dos Povos Indígenas no Brasil. Rio de Janeiro, Campinas: Editora Fiocruz, Abep, 2005.

PINHO, B. A. T. D. G CAMPOS, M. B. Xakriabás: a mobilidade como estratégia de sobrevivência. In: ENCONTRO NACIONAL DE ESTUDOS POPULACIONAIS, 16, 2008, Caxambu. Anais... Campinas: Abep, 2008.

ROMANO, J. O. Índios Proletários em Manaus: o caso dos Sateré-Mawé citadinos, 1982. Dissertação de Mestrado em Antropologia, Brasília: Universidade Nacional de Brasília.

TEIXEIRA, P. (Org.) Sateré-Mawé: retrato de um povo indígena. Manaus: Unicef, FNUAP, 2005.

TEIXEIRA, P. G BRASIL, M. C. Migração, urbanização e características da população indígena do Brasil através da análise dos dados censitários de 1991 e 2000. In: CONGRESO DE LA ASOCIACIÓN LATINOAMERICANA DE POBLACIÓN, 3, 2008, Córdoba. Anais... Córdoba, 2008.

TEIXEIRA, P. G SENA. R. As migrações entre os Sateré-Mawé, povo indígena da Amazônia brasileira. In: ENCONTRO NACIONAL DE ESTUDOS POPULACIONAIS, 16, 2008, Caxambu. Anais... Campinas: Abep, 2008.

TEIXEIRA, P.; MAINBOURG, E. G BRASIL, M. Migração do povo indígena Sateré-Mawé em dois contextos urbanos distintos na Amazônia. Caderno CRH, 22(57): 531-546, 2009. 


\section{A Política de Transferência de Renda Condicionada e os Povos Indígenas no Brasil}

Segundo o Instituto Brasileiro de Geografia e Estatística (IBGE), um total de 896.917 pessoas se autodeclararam indígenas no Censo 2010. Esse número corresponde, aproximadamente, a 0,47\% da população total do país à época. Desse total, 324.834 pessoas foram registradas pelo instituto como vivendo em cidades, e 572.083 em áreas rurais. Segundo dados do Ministério do Desenvolvimento Social e Combate à Fome (MDS), em fevereiro de 2014 havia 100.614 famílias indígenas cadastradas como beneficiárias do Programa Bolsa Família (PBF), distribuídas pelas cinco grandes regiões do país. ${ }^{1}$ Em uma estimativa, poderíamos dizer então que, se consideramos um número médio de quatro pessoas por família, algo como 44,87\% famílias indígenas estariam aptas e recebendo o benefício do PBF em fevereiro de 2014. Diante desse quadro, é fundamental saber de que forma os indígenas se apropriam do benefício financeiro e da lógica implicada em sua implementação, bem como quais são os efeitos que atribuem ao programa sobre seus modos de vida.

Neste capítulo analisamos os resultados obtidos nos estudos etnográficos dos efeitos das transferências monetárias do PBF sobre povos indígenas residentes em sete terras indígenas (TIs), a saber: Alto Rio Negro (AM), Barra Velha (BA), Dourados (MS), Jaraguá (SP), Parabubure (MT), Porquinhos (MA) e Takuaraty/Yvykuarusu (MS). Esses estudos foram contratados pelo MDS, e o trabalho de campo aconteceu entre os meses de setembro de 2013 a fevereiro de $2014 .^{2}$

O PBF foi criado em 20 de outubro de 2003, por meio da medida provisória (MP) n.132, posteriormente convertida na lei n. 10.386/2004, ficando sua gestão a cargo da Secretaria Nacional de Renda de Cidadania (Senarc) do MDS. Esse modelo de intervenção social, baseado no modelo de transferência de renda condicionada (TRC), surgiu nos anos 1990 e foi implantado em diversos países da América Latina. ${ }^{3}$ As condicionalidades do PBF são estabelecidas nas áreas de saúde, educação e assistência social. Para receber o benefício, as famílias devem manter seus filhos de 6 a 17 anos na escola; com relação à saúde, devem fazer exame pré-natal e acompanhamento nutricional e de saúde da mãe e da criança, além de manter as vacinas em dia - o que confere ao programa um caráter intersetorial e 
exige uma estreita e azeitada articulação federativa, envolvendo diferentes ministérios, secretarias estaduais e municipais. O cumprimento de condicionalidades, para os promotores do $\mathrm{PBF}$, é entendido como um compromisso pela garantia de direitos básicos cuja efetivação deve ser compartilhada pelas famílias e pelo poder público, e o acesso aos serviços de saúde e de educação é considerado condição fundamental para permitir o rompimento do ciclo intergeracional da pobreza, ou seja, da manutenção da condição de pobreza de uma geração a outra.

A criação do PBF possibilitou unificar vários procedimentos de gestão e execução das ações de TCR então existentes no país, criados a partir de meados da década anterior. O principal instrumento de unificação dessas ações é o denominado Cadastro Único de Programas Sociais do Governo Federal (a partir daqui referido como Cadastro Único ou, ainda, CadÚnico), por meio do qual as famílias têm acesso tanto ao PBF quanto a outros programas do governo federal. A Caixa Econômica Federal (CEF) é o órgão operador e pagador do benefício. Cabe à Caixa receber e processar as informações que compõem o CadÚnico levantadas pelos municípios, calcular a renda familiar per capita de acordo com os critérios estabelecidos pela Senarc e, por consequência, calcular quanto deve receber cada família. É atribuição da Caixa também realizar os depósitos nas contas individuais na data estabelecida e emitir os cartões magnéticos por meio dos quais a população pode efetuar saques. ${ }^{4}$

A participação social no programa está prevista, sobretudo, por meio de um conselho formalmente constituído no ato de adesão do município, denominado Instância de Controle Social (ICS) do PBF. ${ }^{5}$ A criação ou designação desse conselho é obrigatória e visa a garantir os princípios de transparência da política pública e da gestão compartilhada que devem reger o programa (decreto n. 5.209/2004). Espera-se, ainda, que a ICS tenha em sua composição, além dos representantes do governo local, no mínimo, metade dos seus membros indicados por entidades da comunidade.

Em junho de 2011, foi instituído o Plano Brasil Sem Miséria, com o objetivo de superar a situação de extrema pobreza no país, por meio de ação integrada, tanto do ponto de vista intersetorial, quanto do ponto de vista federativo. Conta com três eixos de ação: garantia de renda, acesso a serviços e inclusão social produtiva. O PBF tem aí um lugar de destaque como estratégia de proteção e promoção social.

\section{Aspectos teórico-metodológicos da investigação}

Todos os pesquisadores e pesquisadoras de campo envolvidos nos estudos etnográficos aqui incluídos tinham um objetivo comum, a saber: produzir um relato etnográfico sobre os efeitos do PBF na população indígena em sete TIs. Seus esforços deveriam estar orientados fundamentalmente para realizar uma 
caracterização compreensiva do processo de inserção das famílias indígenas no $\mathrm{PBF}$, o que significava conhecer o ponto de vista desse ator social, levando em consideração as circunstâncias políticas, econômicas, sociais e culturais em que a inserção estava ocorrendo. Para isso, a cada pesquisador e pesquisadora foram proporcionadas as condições de permanência em campo num tempo mínimo de oitenta meses, para que os mesmos interagissem prioritariamente com os indivíduos e as famílias indígenas beneficiárias do programa. Buscou-se, assim, estabelecer um processo de investigação em que a ação do Estado fosse vista desde abaixo, em que o fazer etnográfico estaria centrado nos sujeitos-alvo da política pública e seus processos.

Coerente com esta perspectiva, foi definido que a metodologia adotada nos diferentes estudos de caso seria de tipo qualitativa, ou seja, os dados seriam produzidos por meio de entrevistas semiestruturadas, do diálogo informal e, principalmente, da observação do dia a dia das pessoas (técnica conhecida como observação participante), tendo por complementos o registro fotográfico e em áudio e a análise documental. ${ }^{6}$

Praticamente todos os pesquisadores e pesquisadoras buscaram adentrar a esfera ou universo conceitual dos seus interlocutores, almejando produzir uma visão mais rica das perspectivas dos sujeitos com os quais interagiram no processo de investigação etnográfica. Para além de entrevistas pontuais, conversas e observações acerca dos temas previstos no roteiro básico comum (RBC), sobre o qual falaremos mais à frente, as rotinas de pesquisa dos antropólogos incluíram múltiplos espaços e modalidades de acompanhamento e participação. A própria natureza da investigação exigia a realização de um estudo multissituado, ou seja, que fossem incluídas outras unidades de observação dentro da área ou campo de análise, e não apenas a comunidade indígena local com a qual tinham por meta interagir.

Neste capítulo, utilizamos o termo etnografia com três significados: 1) como olhar etnográfico: para indicar uma maneira particular de olhar a diversidade social e cultural; 2) como prática de campo: para indicar o conjunto das técnicas e procedimentos que constituem o processo de etnografar uma dada situação sociocultural; 3) como produto: para indicar os diferentes estilos ou gêneros de escrita ou narrativa etnográfica. A etnografia como produto traz mais do que os dados produzidos em campo. Também conhecida como descrição etnográfica, ela contém a interpretação desses dados e sofre a influência da confrontação entre os postulados teóricos e as evidências empíricas obtidas no processo etnográfico. A etnografia - seja como olhar, processo ou produto - é mais do que um procedimento técnico ou acadêmico, é uma atividade fundamentalmente política, pois dela emergem significados que podem gerar, viabilizar e, eventualmente, desconstruir analiticamente, por exemplo, ações de instâncias ou dispositivos de poder que entram em jogo nos arranjos societais - governamentais ou não governamentais. Os antropólogos compreendem 
possivelmente melhor que outros cientistas sociais a estreita relação entre conhecer e dominar no processo de constituição de uma hegemonia colonial. ${ }^{7}$

A ideia de estabelecer um $\mathrm{RBC}^{8}$ que orientasse o processo etnográfico dos sete estudos de caso surgiu em decorrência de vários fatores. Em primeiro lugar, mencionamos as expectativas em relação ao resultado global da pesquisa, ou seja, esperávamos que os estudos etnográficos oferecessem informações qualitativas capazes de orientar possíveis ajustes no PBF direcionado a povos indígenas e que, com base neles, pudessem ser gerados elementos teóricos, metodológicos e operacionais que permitissem adequar o funcionamento do programa às características próprias dos sujeitos de direito que pretende promover.

Outro fator indutor dessa ideia deriva da constatação de que são sete estudos de caso que tiveram em comum, como tema e como problema concreto, os efeitos das transferências monetárias do PBF. Entretanto, foram realizados em TIs específicas, ou seja, em sete unidades de observação distintas, com diferentes povos indígenas em diferentes situações de interação sociocultural com a sociedade regional e por somente um pesquisador ou pesquisadora. Considerando que, mais além das avaliações individuais e específicas, estava o objetivo de discutir e comparar os achados das pesquisas etnográficas, de forma a alcançar níveis de generalização que permitissem promover os ajustes necessários no programa, ou nos seus componentes e logística quando se tratasse de beneficiários pertencentes a povos indígenas, era evidente a necessidade de haver um roteiro básico de questões orientadoras do observar, escutar e escrever.

Por fim, considerou-se que, além das especificidades em formação e experiência de vida e de pesquisa, cada um dos pesquisadores e pesquisadoras iria confrontar-se em campo com realidades em vários aspectos bastante diversas. $\mathrm{Na}$ hipótese de que isso pudesse gerar diferentes priorizações ou ênfases na geração de dados, e na forma e no conteúdo dos seus respectivos relatos etnográficos dificultando ou até inviabilizando o objetivo de discutir comparativamente e de generalizar os achados das pesquisas etnográficas -, ter um roteiro básico comum era necessário e imprescindível.

Supunha-se ainda ser necessário uma ampliação do horizonte ou do campo sociológico de análise para além das fronteiras familiares e da comunidade local, com o objetivo de alcançar a diversidade de espaços, estruturas, sujeitos, significados e práticas sociais (e políticas) envolvidos no (aparentemente simples ato de) receber/gastar o dinheiro, e de entender certos efeitos e limitações da ação do programa na população prioritária do estudo. A noção de redes sociais se mostrou uma boa ferramenta de trabalho. Auxiliou na produção e na interpretação de dados e informações, iluminou vínculos entre pessoas e grupos de pessoas, fossem elas indígenas ou não indígenas, e o papel de agentes mediadores desempenhado por indivíduos e grupos sociais. Colocou em evidência relações de poder e hierarquia, 
relações de tipo compadrio e patrão-cliente, e relações entre o sistema institucional e estruturas não institucionais e intersticiais. A noção de assimetrias (ou de relações assimétricas) surgiu como um complemento necessário à anterior, por revelar e ajudar na caracterização de determinadas situações ou processos socioculturais. A adoção dessas ferramentas teórico-metodológicas exigiu dos pesquisadores e pesquisadoras muita atenção aos relatos sobre a vida e o destino concreto de pessoas, famílias e grupos familiares, além da observação empírica de relações e processos sociais. ${ }^{9}$

Olhar criticamente o conceito de família do PBF, verificando sua aderência aos contextos locais de significado, especialmente no campo das relações de parentesco, e identificar os efeitos gerados no acesso dos indígenas ao recurso financeiro constituiram pontos importantes a serem considerados. ${ }^{10} \mathrm{Da}$ mesma forma, o conceito de residência, utilizado de maneira universalizante pelo programa, nem sempre se ajustava ao modo de vida e à perspectiva cultural dos indígenas. Por fim, em se verificando haver um descompasso entre os conceitos utilizados pelo MDS e os utilizados pelos indígenas, entendia-se ser importante identificar e compreender como essa situação era manejada social e culturalmente pelos indígenas, que artifícios eram empregados por eles nas situações concretas, visando a garantir seu acesso ao recurso financeiro. A noção de adaptação criativa, bastante útil para entender os processos, foi utilizada aqui para referir-se aos processos por intermédio dos quais atores específicos e redes de atores produzem ou coproduzem seus mundos sociais interpessoais e coletivos, retrabalhando repertórios culturais existentes ou conduta aprendida. Ou, ainda, às muitas maneiras pelas quais as pessoas improvisam e experimentam com velhos e novos conhecimentos e experiências, reagindo com imaginação às circunstâncias encontradas (Long, 2007). Essa noção refere-se à relação ativa e criadora da ação humana com o mundo (Bourdieu G Wacquant, 2005). ${ }^{11}$

Disposição semelhante teve de ser adotada em relação ao conceito de comunidade. Verificou-se que chegar a campo com uma definição mais flexível ajudaria a perceber se o PBF, e o acesso ao recurso monetário em particular, estavam tendo efeitos no mundo indígena além dos limites da unidade familiar básica (mulher, marido e filhos e filhas) e sua parentela próxima (grupo de aliança local). Supunha-se que, em alguns casos, os efeitos poderiam estar ocorrendo numa região mais ampla do que a da aldeia ou mesmo da TI, ou ainda se manifestando para lá da fronteira nacional brasileira.

Na elaboração do roteiro foi levado em consideração que o foco dos sete estudos deveria estar na maneira como o programa é operacionalizado, percebido e utilizado pelos/pelas indígenas, e nos efeitos sociais, culturais, políticos e econômicos gerados ou desencadeados pelo recebimento (e não recebimento) das transferências monetárias do PBF. Como veremos mais adiante, o dinheiro que chega às famílias 
indígenas é representado de diferentes maneiras pelas pessoas, adquire múltiplos significados, escapando da lógica da visão puramente economicista. A origem, sua utilidade e finalidades, os riscos, as dificuldades que traz, as possibilidades que abre, entre outras questões, irão aparecer na existência cotidiana aqui e acolá, em discursos e nas práticas sociais dos sujeitos, algumas mostrando compreensões provavelmente de serem pensadas nos gabinetes da burocracia e das ciências sociais acadêmicas.

Vários fatores intervieram na rotina da investigação inicialmente estabelecida, influindo tanto no trabalho em campo, quanto na organização, análise e interpretação dos dados. Citamos, como exemplo, os estilos pessoais e a diferente formação acadêmica dos pesquisadores e pesquisadoras, sua experiência com pesquisas de avaliação de políticas públicas e o contexto sociocultural e político que cada um encontrou e enfrentou no campo para efetivar os objetivos do trabalho. Também influíram as diferentes estratégias dos pesquisadores e pesquisadoras para aplicar as técnicas qualitativas de investigação, diante da situação inevitável de dissimetria (Bourdieu, 2011) ligada à distância sociocultural que perpassa e marca a relação de pesquisa. Vários relataram resistências político-culturais da parte tanto de indígenas quanto de agentes sociais não indígenas, inclusive de pessoas localmente envolvidas na implementação do programa, influenciando a obtenção dos dados almejados. Além das dificuldades de comunicação decorrentes da falta de domínio do idioma indígena por parte de alguns pesquisadores e pesquisadoras, no caso da TI Barra Velha (BA), a pesquisadora se deparou com a resistência dos seus interlocutores indígenas para falar na presença do gravador ligado. É sempre bom lembrar que a relação entre o sujeito pesquisador e sujeitos pesquisados é fundamentalmente, e apesar de tudo, uma relação social e intersubjetiva que exerce efeitos sobre o processo e o produto etnográfico.

\section{Análise dos achados}

Num esforço de síntese, a seguir comentaremos os principais achados do trabalho de campo, segundo a divisão temática estabelecida por ocasião da elaboração do RBC.

\section{Percepções e significados acerca do PBF}

A proposta de repasse de recursos financeiros pelo programa é bem aceita pela população. Há uma forte associação desses recursos com a parcela infantil e jovem da população, como sendo o dinheiro "das crianças", devendo ser destinado

prioritariamente a dar-lhes condições para frequentar a escola. É percebido também 
como um dinheiro destinado às mulheres, para que fiquem responsáveis por esse objetivo, e a outros associados ao bem-estar das crianças.

A pesquisa também aponta para um baixo conhecimento da população indígena em geral sobre o PBF. No plano discursivo, não foram encontradas pessoas que pudessem definir, descrever e explicar o programa - seus objetivos, regras, procedimentos, como obter ajuda para a resolução de problemas no percurso que vai do cadastramento ao saque do recurso financeiro etc. - nos mesmos moldes como ele é compreendido, descrito e explicado pelos seus operadores, por exemplo, no MDS em Brasília, ou expresso nos textos dos manuais e documentos oficiais. Mas esse fato não significa que as pessoas não tenham suas explicações e que, no dia a dia, não busquem se comportar de forma a garantir a continuidade do acesso ao recurso, o que poderá ser mais bem compreendido nas próximas seções.

O processo investigativo também revelou que há diferentes níveis de conhecimento dentro das comunidades sobre a relação do recurso financeiro e o MDS e outros âmbitos do governo federal. Foi até mesmo identificada certa discrepância entre as famílias em relação ao papel das lotéricas e dos comerciantes na operacionalização da rede de atores sociais constituída para garantir-lhes o acesso aos recursos financeiros e aos direitos básicos, especialmente à saúde e à educação escolar. Algumas vezes esses comerciantes eram representados como agentes centrais e decisores para o acesso das famílias indígenas aos recursos e serviços públicos. Compreende-se que haja limitações na capacidade humana, individual e coletiva, para conhecer ou até imaginar o conjunto das causas de um dado acontecimento e as consequências que se desdobram e se ramificam das decisões, atos ou atividades dos sujeitos. Mas nas situações aqui tratadas, a explicação para o problema da compreensão deve ser buscada no tipo de integração social que se dá, no plano local, de favores e dependências, que produz e reproduz significados e relações sociais naturalizadas ao longo do tempo. Tentar compreender essa confusão pressupõe a incorporação, no quadro explicativo, da análise do tipo de interação face a face e das práticas recíprocas de busca de autonomia e dependência entre os atores e coletividades em cena, especialmente entre os indígenas e os comerciantes e agentes públicos. Como veremos mais à frente, essa situação também é fruto da forma como vêm operando contextualmente os agentes responsáveis locais dos Centros de Referência da Assistência Social (Cras) e dos Centros de Referência Especializado de Assistência Social (Creas).

Cabe ainda registrar a crítica generalizada sobre o valor do benefício recebido: a população indígena o considerava insuficiente. Essa crítica, mais acentuada por parte das famílias com grande quantidade de filhos, às vezes era difusa, ora dirigida ao "governo", ora a "Brasília". 


\section{Cadastro Único}

Há pouco conhecimento disseminado entre a população sobre o que é o CadÚnico e sobre o fato de que ele é a porta de entrada para outras políticas além do PBF. Parece estar ocorrendo, no mínimo, uma falha na forma de repasse de informação sobre o programa e o cadastro. É provável que as unidades do Sistema Único de Assistência Social (Suas) que estão em contato direto com a população não estejam priorizando o assunto.

A exigência demasiadamente rígida de documentação feita pelos agentes locais do PBF está comprometendo o acesso da população ao programa. No Alto Rio Negro, como em outras TIs, não é aceito o Registro Administrativo de Nascimento de Indígena (Rani) para credenciar a pessoa a ter acesso ao cadastro. São exigidos documentos que, para o contexto local, criam barreiras em vez de facilitar o acesso aos benefícios do programa.

A análise de um desses casos, com auxílio da Senarc, permitiu à pesquisadora que trabalhou na TI Takuaraty/Yvykuarusu (MT) identificar uma discrepância entre a renda que constava no cadastro e a que a família afirmava ter declarado. Como não se trata de um episódio isolado, caberia verificar se os operadores locais do CadÚnico, em alguma medida, estão exorbitando de suas atribuições, violando o direito à declaração autônoma dos beneficiários, e tomar as medidas cabíveis para que não ocorra mais esse tipo de abuso.

\section{Condicionalidades}

Os relatos são diversos, não sendo possível construir um quadro amplo e profundo da perspectiva indígena sobre as condicionalidades do PBF. Mas o que se depreende deles é que o tema é desigualmente compreendido pela população. Constata-se, também, que a compreensão além de desigual é dinâmica. Decorre do aprendizado, que, infelizmente, às vezes, tem consequências bem desagradáveis. Ao não serem atendidas as condicionalidades, ou se a informação relativa ao cumprimento das condicionalidades não foi inserida no sistema de informações do PBF no prazo certo, o benefício é bloqueado. A pessoa, então, tem de buscar se informar por que isso ocorreu. O bloqueio do recurso, por menor que seja, para uma família de baixíssima renda, vai fazer a diferença.

A obrigatoriedade de frequência escolar foi questionada em praticamente todas as TIs investigadas. Diversas dificuldades operacionais foram mencionadas para cumprir essa condicionante, como, por exemplo, a ausência de um sistema de registro e acompanhamento eficiente e a falta de entendimento dos operadores locais em relação aos recursos ou condições estruturais necessários para as crianças frequentarem a escola e terem um aproveitamento satisfatório. Foram citados também os problemas de transporte, de pessoal qualificado e interessado e com 
frequência regular (nos referimos a professores); a falta de adequação de alguns estabelecimentos de ensino (escola e salas) aos padrões culturais locais e às condições ambientais/climáticas. Há ainda problemas com a merenda que chega às escolas: atraso na entrega, quantidade insuficiente, baixa qualidade e falta de segurança de consumo - em alguns casos em visível estado de deterioração.

De diferentes maneiras ficou evidente que é necessário haver uma avaliação da situação do sistema local de atenção à saúde da população, e em particular do atendimento às exigências do programa, como ações de monitoramento do adequado desenvolvimento das crianças, vacinação, pré-natal e atenção à saúde materno-infantil. O fluxo de informações sobre as condicionalidades de saúde parece não ter alcançado ainda o objetivo estabelecido, ou seja, não alimenta ações para corrigir as deficiências e vulnerabilidades constatadas na população investigada, no que concerne à vigilância de seu estado alimentar-nutricional e de saúde integral. Esse quadro acaba corroborando a visão expressa na maioria dos relatos: a de que as condicionalidades são uma "tarefa" ou um "pedágio", em muitos casos algo bastante oneroso que os beneficiários têm de realizar ou pagar para viabilizar e garantir a continuidade do acesso ao benefício. Nas TIs Dourados, Alto Rio Negro, Takuaraty/Yvykuarusu e Parabubure, houve reclamações graves sobre o sistema de saúde, a qualidade dos serviços prestados, entre outras.

\section{Logística de pagamento/recebimento do benefício}

Em todos os relatos foi constatada a presença do patrão como agentechave no acesso/recebimento do benefício financeiro. Em Porquinhos, por exemplo, a investigação concluiu que o cartão de praticamente todas as famílias estava nas mãos desse personagem. Ele é um comerciante da região que "facilita" o acesso aos locais de saque do recurso e orienta os indígenas a gastar o dinheiro nos seus estabelecimentos comerciais.

O controle sobre os cartões magnéticos, a título de garantir o pagamento da dívida contraída, é tal que as pessoas acabam alienando-se do valor que recebem ou deveriam estar recebendo de acordo com as regras de cálculo do programa. Há nesse controle um forte indício de conluio entre comerciantes e, especialmente, funcionários de estabelecimentos lotéricos. No caso destes últimos, verificou-se que alguns deles se aproveitavam das dificuldades dos indígenas de entendimento e de manuseio do cartão, para dar-lhes somente parte do valor do benefício, ou mesmo dizer-lhes que não havia nada a receber, aparentemente apropriando-se desse recurso não repassado aos indígenas. É o caso do "dinheiro desaparecido", registrado em São Gabriel da Cachoeira.

Para sacar o benefício, os indígenas têm que se deslocar, o que leva alguns deles a relatarem que o "PBF faz as pessoas saírem da aldeia" e enfrentarem dificul- 
dades de transporte e de alimentação, pressão psicológica e constrangimentos vários nos estabelecimentos onde sacam e onde gastam o recurso. No caso dos Xavante, os constrangimentos envolvem mulheres que vão com as crianças até os locais de saque e que, muitas vezes, esperam por horas na fila do caixa para serem atendidas.

Se, na TI Alto Rio Negro, a aspiração manifestada pelos indígenas, de haver uma caixa eletrônica em cada comunidade, é tecnicamente inviável na atualidade, pode-se indagar por que não instalar caixas nos distritos administrativos tradicionais de Cucui, Taracuá e Pari Cachoeira, ou onde há pelotões do exército e dispositivos de comunicação e vigilância de fronteiras. Essas medidas certamente aproximariam o programa das aspirações locais no tocante ao acesso ao benefício.

Entre os Guarani e Kaiowá da TI Takuaraty/Yvykuarusu, as dificuldades para o recebimento do benefício acabam inserindo e prendendo os indígenas em uma teia de relações das quais eles dependem, quase completamente, tanto para receber o benefício como para usufruir dele.

\section{Utilização do benefício financeiro}

Em praticamente todos os locais investigados, o discurso indígena de que o dinheiro do PBF "é para as crianças" se mostrou coerente com a destinação preferencial dada ao benefício: compra de material escolar, roupas e calçados para as crianças poderem frequentar as escolas de maneira "adequada". Em praticamente todas as investigações, observou-se que esse direcionamento na utilização do dinheiro decorre da pressão que há sobre os pais e, especialmente, as crianças, como exigência da instituição escolar em que elas estão sendo inseridas.

Em contrapartida, também há registros em distintos locais em que o benefício é destinado para compra de alimentos, complementares ao alimento não produzido (roçado) ou obtido (caça, coleta e pesca) localmente. Para o "algo mais", como referido em Dourados, ou um ingrediente para enriquecer a "mistura", apreciada pelos Xavantes. Mas a depender da situação, especialmente das famílias em situação de vulnerabilidade, o recurso pode ser utilizado preferencialmente na compra de comida para suprir uma situação de carência alimentar. Essa situação ocorreu com famílias que não dispunham de um roçado próprio suficientemente produtivo, ou não recebiam uma cesta básica capaz de atender às suas necessidades.

\section{Formas de relação dos indígenas com o poder público e a sociedade local}

Não foi registrada em uma única TI a participação dos indígenas nas instâncias de controle social do programa. 
A figura do patrão emerge aqui novamente, posto que não é pouco comum esse personagem ter fortes vínculos com os poderes políticos e a administração pública municipal. Trata-se de uma figura cuja persistência ao longo do tempo deriva da insuficiência e inadequação das ações do poder público nas políticas que se destinam aos povos indígenas. Sua presença é diretamente proporcional à exclusão dos indígenas e à falta de consideração de suas especificidades socioculturais e territoriais.

No caso de Dourados, vê-se que a disposição dos órgãos públicos está bastante aquém das necessidades dos moradores da TI. Há um jogo de empurraempurra e uma clara posição política da prefeitura de não facilitar a vida dos indígenas, recusando-se a utilizar seus tratores para apoiá-los na preparação da terra dos roçados familiares e na produção autônoma. A intenção é fazer com que os indígenas adiram e deem continuidade aos arranjos de parcerias e aos arrendamentos de lotes aos não indígenas no interior da reserva indígena para o plantio de soja.

No Alto Rio Negro, os pesquisadores e pesquisadoras confrontaram-se com diversas situações discriminatórias contra os indígenas por parte de comerciantes, funcionários de secretarias e outras instituições municipais, como também de agentes públicos estaduais e federais, responsáveis por atender os indígenas. Esse mesmo comportamento foi identificado por praticamente todos os investigadores nos seus respectivos estudos de caso.

\section{Acesso dos indígenas às unidades do Suas (Cras e Creas)}

Os indígenas afirmam desconhecer ou saber muito pouco a respeito dos Cras e Creas, embora haja relatos de terem recorrido a essas unidades, especialmente aos Cras, para indagar o motivo do bloqueio do cartão, demandar inclusão ou buscar alguma outra informação.

Também há reclamos de que não são bem atendidos pelos funcionários dos centros. No caso do Alto Rio Negro, alguns disseram ser mais bem tratados e informados na casa lotérica do que no Cras. Outros testemunharam que se sentiram humilhados quando foram à unidade.

\section{Atividades produtivas e comerciais locais e segurança alimentar}

Em nenhum dos casos houve registro de abandono das atividades produtivas $m$ decorrência do recebimento do benefício. Ao contrário, em alguns casos, o recurso era utilizado para potencializar a capacidade produtiva e alimentar, como na compra de material de pesca e ferramentas.

Em Dourados, o trabalho fora da TI é parte da estratégia de sobrevivência e sustentação das famílias, especialmente dos homens pais de famílias e mulheres 
jovens. Na grande maioria das vezes, são trabalhos temporários em canaviais, frigoríficos etc., sem qualquer esquema de seguridade no trabalho ou seguridade social.

\section{Questões de gênero}

A titularidade do cartão em nome das mulheres não trouxe conflitos perceptíveis em nível familiar. Elas têm ficado contentes com a situação, pois podem destinar o recurso para os fins que julgam mais adequados e importantes. Em geral, tem sido direcionado para as crianças, atendendo algumas demandas delas, mas fundamentalmente provendo as condições necessárias para frequentar a escola.

O tema merece um aprofundamento para além do registro do uso do cartão. Sabe-se, por exemplo, que as mulheres Xavante têm de enfrentar alguns desafios para chegar até os pontos de saque do benefício.

\section{Discussão e recomendações}

Como na seção anterior, manteve-se a divisão temática estabelecida por ocasião da elaboração do RBC.

\section{Percepções e significados acerca do PBF}

Em praticamente todas as TIs, os indígenas demandaram ao MDS um planejamento/execução, de maneira coordenada, com as demais instituições, de ações de informação sobre o PBF. No caso da TI Parabubure (MT), por exemplo, foram constatadas graves lacunas de informação, bem como informações inconsistentes, confusas e contraditórias, ou até mesmo enganosas. Esses comunicados foram repassados aos Xavante por comerciantes, donos e funcionários de lotéricas e, também, pelos diferentes agentes públicos locais. O mesmo problema foi identificado em contextos tão distintos quanto as TIs Alto Rio Negro (AM) e Takuaraty/ Yvykuarusu (MS), o que exige uma ação informativa qualificada e culturalmente adequada do MDS à população indígena sobre o funcionamento do programa, suas regras e procedimentos (CadÚnico, condicionalidades, recebimento e utilização do benefício, o papel do Cras etc.). Houve também um grande interesse por saber como acessar outros benefícios via CadÚnico. Muitas famílias não tinham conhecimento sobre o assunto ou não sabiam como e onde obter informações qualificadas.

Esse desconhecimento sobre o conjunto dos procedimentos do programa acaba por impactar também negativamente a possibilidade de controle social - dos indígenas e suas organizações locais e regionais, por exemplo, a Federação das Organizações Indígenas do Rio Negro (FOIRN) -, sobre a gestão local do programa 
e sobre os agentes financeiros (Caixa) e comerciais (lotéricas) responsáveis por repassar o recurso financeiro às famílias. Particularmente as lotéricas têm se mostrado problemáticas na relação com as famílias beneficiárias.

\section{Cadastro Único}

Recomenda-se aos gestores do PBF que estimulem as ações de documentação da população e contribuam para que seja obtida. Foram constatados vários casos de famílias em estado de vulnerabilidade, ou com um perfil semelhante a beneficiários, que não haviam conseguido se cadastrar porque não tinham a documentação solicitada pelo programa. Esse fato ocorreu com certa frequência com mulheres, o que fez com que os maridos ficassem como titulares do cartão.

A pesquisa também pôde constatar que os funcionários e funcionárias que estavam em contato direto com a população necessitavam ser mais bem preparados para se comunicarem com os indígenas. A falta de pessoal com fluência no uso dos idiomas locais tem sido apontada como um obstáculo à compreensão entre as partes. No caso dos Guarani e Kaiowá, foi recomendada a formação de um ou dois agentes mediadores de referência selecionados entre a população Guarani e Kaiowá para orientar a população, no idioma local, em questões de documentação, informação e resolução de outros problemas. Essa recomendação pode muito bem ser expandida para o conjunto dos Cras aos quais recorram famílias indígenas, bem como para as prefeituras municipais.

Constatou-se a necessidade do MDS de insistir especialmente com os agentes públicos que estão em contato direto com a população indígena para que reconheçam e valorizem o Registro Administrativo de Nascimento de Indígena (Rani), pois se trata de um documento válido para políticas públicas que tenham povos indígenas como beneficiários. O ministério deve, ainda, promover uma ampla divulgação entre os gestores e funcionários nos diferentes níveis da administração pública sobre a documentação necessária para a inscrição de famílias no Cadúnico. Como foi comentado anteriormente, até mesmo entre funcionários públicos foram encontradas inconsistência, confusão e contradição nas informações relativas ao cadastramento.

Por fim, recomenda-se que os agentes do Estado se desloquem periodicamente às aldeias para atualizar os cadastros, e que as prefeituras sejam responsabilizadas por possíveis falhas no processo, especialmente quando dificultarem a inclusão de potenciais beneficiários ou acarretarem bloqueio na transferência do recurso financeiro às famílias. 


\section{Condicionalidades}

A noção de condicionalidade, como definida pelos idealizadores do programa, é algo que soa estranho às famílias indígenas em que a pesquisa foi realizada. Vários entrevistados afirmaram desconhecer as regras, e outras só tomaram conhecimento delas quando tiveram a transferência bloqueada. Há também quem questione sua aplicação, uma vez que as escolas frequentadas pelos filhos apresentam diversos tipos de problemas: o fornecimento de água (de preferência tratada) não é suficiente; as instalações estão em estado precário ou são ambientalmente inadequadas (na TI Parabubure, por exemplo, as crianças Xavante frequentam escolas incompatíveis com o clima da região, o que causa extremo desconforto térmico e impede a permanência dos alunos nas salas de aula); não há transporte adequado; faltam professores ou estes não cumprem a carga horária total exigida; os materiais escolares fornecidos não atendem às necessidades básicas e, em geral, estão desconectados da dinâmica da vida nas aldeias e do universo indígena.

Em todas as TIs, há ainda problemas com a merenda escolar, pois não é oferecida em quantidade e qualidade adequadas, apesar de o Programa de Aquisição de Alimentos (PAA) e o Programa Nacional de Alimentação Escolar (PNAE) disporem de mecanismos de gestão que autorizam a compra direta de produtos do agricultor familiar cadastrado (e também de famílias indígenas), sem necessidade de licitação, democratizando e descentralizando as compras públicas e criando mercado para os pequenos produtores. Essa estratégia, além de possibilitar o fornecimento de alimentos de melhor qualidade e culturalmente mais adequados às escolas nas TIs, estimulando a produção de alimentos oriundos da agroecologia e das cadeias da sociobiodiversidade indígenas, a um custo mais baixo, tem o potencial de valorizar a produção local e constituir um fator de geração de renda adicional às famílias.

Em situação semelhante foram encontrados as instalações e os serviços de atenção à saúde a que as famílias têm acesso na sua vida cotidiana. Também foram identificados problemas de transmissão e atualização das informações de saúde via Sistema de Vigilância Alimentar e Nutricional (Sisvan) e Sistema de Informação da Atenção à Saúde Indígena (Siasi), o que resultou em bloqueio na transferência do recurso do PBF a supostos descumpridores da condicionalidade de saúde.

Assim, recomenda-se ao programa que repense, junto com os beneficiários indígenas, se é possível e desejável manter esse sistema de condicionantes, que pune unilateralmente os beneficiários e desconsidera o estado atual de precarização dos serviços de saúde e de educação escolar destinados aos povos indígenas. É necessário também que o MDS tome a frente e organize um processo de discussão visando a identificar os fatores que estão dificultando a oferta de serviços de qualidade à população (educação escolar e ações de saúde) e as estratégias que necessitam ser adotadas para reverter esta situação no mais curto prazo possível. A Câmara Interministerial de Segurança Alimentar e Nutricional (Caisan), bem 
como o Conselho Nacional de Segurança Alimentar e Nutricional (Consea), pelo papel que ambos têm para a efetivação da Política e o Plano Nacional de Segurança Alimentar e Nutricional (Plansan) 2012/2015, poderão ter um papel importante nesse processo em que a participação informada de representantes indígenas deve ser considerada imprescindível.

\section{Logística de pagamento/recebimento do benefício}

O acesso aos pontos de saque do recurso transferido pelo PBF foi considerado um problema em praticamente todas as TIs incluídas na pesquisa. Como vimos no caso da TI Alto Rio Negro (AM), dependendo do local de moradia da família, o deslocamento pode demandar vários dias por rios, igarapés e caminhos no meio da mata. Horas de viagem também foram mencionadas nas TIs Parabubure (MT), Porquinhos (MA) e Barra Velha (BA). A dificuldade de acesso (físico e também culturallinguístico), em parte por omissão do Estado, é um dos principais condicionantes (o caldo de cultivo) da continuidade do sistema exploratório da patronagem. As complexidades culturais e os dilemas do desejo de consumo têm também um lugar de destaque na configuração e reprodução desse tipo de sistema, e os comerciantes (patrões) sabem bem disso.

O círculo vicioso de crédito/endividamento que caracteriza o sistema de patronagem, mascarado pela consciência social ou ideologia da ajuda e da facilitação, que, por sua vez, assegura há décadas a mais-valia dos patrões, foi encontrado nos vários estudos de caso operando os recursos transferidos pelo PBF. Dado o nível atual de desinformação dos indígenas sobre o programa, em várias TIs, as agências lotéricas e os comerciantes são percebidos como parte da estrutura de gestão do programa. Assim, não nos causará surpresa que se produzam em breve críticas acusando o PBF de contribuir (não intencionalmente, óbvio) com a reprodução e até mesmo a renovação (modernização) de sistemas e práticas de dominação e exploração das populações indígenas em nível local, apesar das boas intenções dos gestores e técnicos do programa. Estamos diante do que na teoria social é chamado de condições inimaginadas e consequências não desejadas da ação.

Recomendamos que se busque aproximar os pontos de saque dos locais onde vivem as famílias. Na TI Barra Velha (BA), por exemplo, a instalação de uma lotérica mais próxima aos limites da TI ou, alternativamente, a gratuidade do transporte para os beneficiários do PBF que precisam se deslocar da aldeia até a cidade mais próxima a fim de sacar o seu benefício são ambas ótimas opções. No caso da TI Porquinhos (MA), além de um transporte para o deslocamento dos Canela Apanyekra da aldeia até a cidade de Barra do Corda, é urgente que se pense em um local onde eles possam ficar hospedados. Na TI Takuaraty/Yvykuarusu (e em outras TIs sul do MS), é necessário oferecer aos habitantes algum tipo de 
transporte coletivo gratuito. Constatou-se haver falta de alternativas de transporte, e o seu custo relativamente elevado deixam os indígenas a mercê dos patrões, que retêm seus cartões ou documentos pessoais quando se endividam. Na TI Alto Rio Negro, a CEF deve buscar meios para abrir uma agência com plenas atribuições na cidade de São Gabriel da Cachoeira, e o MDS deve considerar a possibilidade de implementar uma modalidade diferente de pagamento para povos indígenas, com a criação de equipes volantes. O recurso repassado às prefeituras, o denominado Índice de Gestão Descentralizada (IGD), cuja administração é (teoricamente) de responsabilidade das secretarias de Assistência Social, poderia custear parte desse sistema, desde que devidamente carimbado.

É preciso haver uma ação do MDS, em articulação com o Ministério Público Federal e a Polícia Federal, visando a desbaratar as redes de exploração/ expropriação de indígenas, promovidas por comerciantes formal e informalmente estabelecidos nas localidades onde há saque do recurso do PBF. No caso da região de fronteira do Mato Grosso do Sul com o Paraguai (TI Takuaraty/Yvykuarusu), onde comerciantes de ambos os países estão envolvidos com a retenção de cartões, verificou-se que será necessária uma operação conjunta, envolvendo instituições de ambos os países.

Recomenda-se também uma ampla fiscalização sobre as lotéricas. Foram constatadas regras arbitrárias para sacar o benefício (por exemplo, a exigência de que os beneficiários recebam em dias fixos, obrigando-os a um gasto mensal de passagem para ir até a cidade), e a imposição de raspadinhas como troco e da compra de capa para o cartão. Também há suspeitas de apropriação de parte do recurso financeiro transferido, sob a alegação de que o PBF ou depositou menos, ou não depositou naquele mês, informação dada após o funcionário ter consultado o saldo com o cartão e a senha do beneficiário.

São necessárias também ações de informação e capacitação dos indígenas para que eles mesmos, juntamente com suas organizações, consigam fazer valer seus direitos diante dos abusos dos patrões. Por exemplo, um programa que contemple conteúdos básicos de economia financeira para famílias indígenas que o desejarem e cursos de formação de indígenas para atuarem como acompanhantes das famílias no momento do recebimento da renda transferida pelos programas sociais, especialmente no caso de idosos.

\section{Utilização do benefício financeiro}

Devem ser oferecidas aos povos indígenas condições de acesso a alguns domínios de conhecimento específicos, necessários para não serem enganados tanto no recebimento quanto no gasto do benefício. A partir do estudo de caso TI Porquinhos, sugerem-se: português (principalmente leitura e escrita), mate- 
mática aplicada (principalmente contabilidade) e direitos legais, bem como um módulo sobre políticas sociais, com um destaque para o PBF (incluindo suas regras e procedimentos).

\section{Formas de relação dos indígenas com o poder público e a sociedade local}

Recomenda-se a criação ou efetivação da instância de controle social (ICS) do programa, e que, nos municípios em que há povos indígenas, seja obrigatória a participação de representação indígena.

Para a TI Dourados, além da participação informada de representante indígena na ICS, faz-se necessária a criação de um órgão de consulta à comunidade para assuntos de família. Se a Fundação Nacional do Índio (Funai), o Ministério Público Federal e as lideranças da TI abrissem um diálogo para chegar a mecanismos apropriados, possivelmente se resolveria adequadamente uma série de problemas que hoje são encaminhados de forma morosa e ineficiente, dando margem a conflitos e insatisfação generalizada, além de potenciais injustiças. A essas medidas, junta-se o reconhecimento institucional dos espaços políticos nativos, isto é, das suas formas próprias de organização social e política e de tomada de decisão - um procedimento a ser aplicado ao conjunto das TIs.

No caso da TI Alto Rio Negro (AM), é preciso centralizar em um só local no município todos os serviços de atendimento às populações indígenas, relacionados ao acesso e execução do PBF no município. Esse local deve ser acessível e oferecer estrutura às famílias indígenas, dado que mulheres usualmente comparecem às unidades acompanhadas de filhos pequenos. Muito provavelmente esse tipo de encaminhamento poderia também ter efeitos positivos em outras TIs.

\section{Acesso dos indígenas às unidades do Suas (Cras, Creas)}

O MDS deve promover esforços para aproximar e adaptar as condições materiais e humanas das unidades do Sistema Único de Assistência Social (Suas) ao mundo indígena, aos diferentes modos de pensar e de se comportar dos povos indígenas com os quais se está trabalhando. Em primeiro lugar, organizando ações de capacitação específica voltadas para as equipes do PBF que estão nos municípios e se relacionam direta e indiretamente com indígenas. Durante as pesquisas de campo, muitos beneficiários se queixaram de que eram mal recebidos e mal informados, tratados com evidente má vontade e descaso, e de que os funcionários que conheciam a língua nativa do indígena, quando havia, muitas vezes se recusavam a atendê-los falando idioma distinto do português.

A contratação de pessoal com fluência na(s) língua(s) falada(s) pelos indígenas é outra medida que poderá promover efeitos positivos na relação das unidades 
do Suas com as famílias indígenas. Essa demanda, mais acentuada entre as mulheres indígenas, foi apresentada em todas as TIs onde a população tem dificuldades para entender e se expressar em português.

A formação de agentes de referência é outra demanda que emergiu de várias pesquisas e que recomendamos ser incluída no plano de trabalho e no orçamento anual do MDS. Além de informar e orientar os beneficiários de cada comunidade sobre o PBF e outros programas sociais na língua indígena, eles poderiam cumprir outras funções, como verificar se os dados cadastrais estão atualizados. A existência desse agente de referência na aldeia, a exemplo do agente indígena de saúde (AIS) e do agente indígena de saneamento (Aisan), permitiria esclarecer muitas dúvidas in loco, evitando deslocamentos desnecessários até a cidade.

\section{Atividades produtivas e comerciais locais e segurança alimentar}

Sem dúvida, é possível afirmar que, em alguma medida, o programa tem contribuído para a sustentabilidade alimentar da população, seja viabilizando a compra direta de alimentos, seja proporcionando as condições para a aquisição de ferramentas e instrumentos a serem utilizados na geração de alimentos (especialmente nos roçados e na pesca). Entretanto, dissociado de outras ações, seus efeitos serão inevitavelmente insuficientes. É preciso ser retomada, urgentemente, a tese de que só com uma política integrada, intersetorial, será possível enfrentar os desafios da sustentabilidade alimentar entre os povos indígenas no país. No caso dos Guarani e Kaiowá, no Mato Grosso do Sul, bem como dos Guarani da TI Jaraguá, em São Paulo, se não for resolvido o problema fundiário, destinando-lhes as porções de terra (territórios) demandadas, dificilmente esses povos alcançarão as desejadas autonomia e segurança alimentar unicamente com cestas básicas e transferências de renda.

A implementação de ações destinadas ao fortalecimento da denominada economia indígena emergiu como demanda em praticamente todos os locais investigados. É necessário investir nas iniciativas de produção, distribuição, consumo e comercialização de bens e serviços oriundos da sociobiodiversidade indígena local, bem como apoiar materialmente as iniciativas familiares e coletivas de produção de alimentos, com o fornecimento de instrumentos de trabalho nas roças, manejo florestal e piscicultura. As ações de Assistência Técnica e Extensão Rural (Ater) culturalmente qualificada e continuada certamente têm um papel importante a cumprir, e a experiência recente mostra que é possível uma assistência técnica sensível às demandas, desejos e expectativas indígenas (Verdum, 2005, Verdum G Araujo 2010).

No caso dos Canela da TI Porquinhos (MA), a população gostaria que o MDS a auxiliasse na implementação de uma cooperativa, junto com outros povos 
Timbira (Canela Ramkokamekra, Krinkatí, Krahô, Pykobjê, Parkatejê, por exemplo), para facilitar o acesso aos produtos dos kupen (não Timbira ou "brancos") sem a intermediação dos patrões. Assim, não precisariam se deslocar à cidade para obter produtos no comércio, em especial alimentos.

Já entre os Guarani e Kaiowá da TI Dourados, o incentivo à agricultura familiar e a projetos de reflorestamento e reconstituição das matas ciliares mostrou ser a ação mais urgente a ser implementada, particularmente devido ao seu potencial efeito direto e positivo na segurança alimentar das famílias. Viabilizar planos regionais e projetos locais de gestão territorial e ambiental, para que a população possa progressivamente dispensar a cesta de alimentos, é o caminho recomendado. É necessário também tentar obter apoio das prefeituras: a situação no Mato Grosso do Sul mostrou-se emblemática do uso político de recursos públicos contra os indígenas. O maquinário poderia ser disponibilizado para que a terra fosse preparada no tempo certo, viabilizando a agricultura familiar indígena e, consequentemente, a sustentabilidade e soberania alimentar dessa parcela da população.

Infelizmente, em algumas TIs, a distribuição de cestas básicas é ainda uma ação necessária, mas recomenda-se rever os itens que entram na sua composição. Em praticamente todas as TIs, foi apontado o problema da qualidade de certos produtos e a inadequação de alguns itens em relação aos hábitos alimentares locais. Além de melhorar a qualidade dos produtos, deve-se adequar a quantidade ao tamanho da família. Foi observado na TI Takuaraty/Yvykuarusu (MS), por exemplo, que, em alguns casos, um tipo de cesta, com a mesma quantidade de produtos, é entregue para família de tamanhos muito diferentes (com dois até 12 membros).

Entendemos que, além de ações setoriais, promovidas pelo MDS, isoladamente ou em articulação com outros ministérios e órgãos vinculados (MDA, MS, MEC, Funai), é preciso haver uma ação conjunta do Conselho Nacional de Segurança Alimentar e Nutricional (Consea) e da Câmara Interministerial de Segurança Alimentar e Nutricional (Caisan). Ambas as instâncias têm um papel decisivo na solução de muitos problemas e desafios identificados na pesquisa realizada entre 2013 e 2014.

\section{Considerações finais}

É necessário e urgente que o governo promova uma discussão com a participação de lideranças e organizações indígenas, técnicos/as e pesquisadores/as visando à constituição de um subprograma Bolsa Família Indígena, com regras e procedimentos próprios, a exemplo do que ocorre no setor Saúde, e que esse subsistema específico integre o conjunto das ações sociais do MDS dirigidas aos povos indígenas. Esse processo deve transcorrer com participação e consulta aos indígenas, por meio das suas organizações e instituições próprias, para definir as 
mudanças necessárias e a maneira de implantá-las. Lembramos que os investigadores e investigadoras trouxeram do campo expectativas, demandas e questionamentos dos indígenas em relação ao programa. Houve grande interesse no estudo e em seus possíveis resultados concretos para o funcionamento do PBF entre eles. Além disso, durante as consultas prévias informadas, realizadas nas comunidades antes do início do trabalho de campo, houve o compromisso institucional do MDS de apresentar os resultados da pesquisa, ao menos nas TIs onde os levantamentos foram realizados.

1 Em 2008, após quatro anos de criação do PBF e sem que houvesse qualquer normatização a respeito da inclusão de famílias indígenas nesse programa, foi constatada a existência de 53.513 famílias cujos integrantes se autodeclararam indígenas, residentes em 392 municípios (Carvalho, 2010).

2 Os estudos etnográficos foram realizados pelos seguintes antropólogos: Adriana Romano Athila - TI Rio Negro; Bruno Nogueira Guimarães - TI Porquinhos; Danielli Jatobá França TI Jaraguá; Joceny de Deus Pinheiro - TI Barra Velha; Lydie Oiara Bonilla Jacobs - TI Takuaraty/ Yvykuarusu; Othília Maria Baptista de Carvalho - TI Parabubure; Spensy Kmitta Pimentel Reserva Indígena de Dourados. Na condição de consultor contratado pelo MDS, tive como atribuições auxiliar no planejamento e no acompanhamento das investigações de campo, e analisar e consolidar os sete estudos etnográficos. Este capítulo tem como referência principal o Relatório Final Estudos Etnográficos sobre o Programa Bolsa Família entre Povos Indígenas (Brasil, 2016), organizado por mim e publicado pelo MDS em novembro de 2016, pouco mais de dois anos após a conclusão do estudo e da entrega e aprovação do relatório final pela Secretaria de Avaliação e Gestão de Informações (Sagi) do ministério.

3 O México foi o primeiro país a adotar e implantar o modelo TRC na América Latina e Caribe, com o Programa de Educación, Salud y Alimentación (Progresa), de 2000, que em 2002 passou a ser chamado Programa de Desarrollo Humano Oportunidades (Oportunidades).

4 Sobre o PBF, ver Campello e Neri (2013), Castro e Modesto (2010) e Brasil (2013).

5 Conforme a portaria GM/MDS n. 246/2005, a presença de uma instância de controle social é pré-requisito para a adesão dos municípios ao PBF.

6 A observação participante é a principal técnica de campo do processo etnográfico e da produção de conhecimento na antropologia. Inclui observação e participação. Requer do investigador a disposição de mergulhar na subjetividade das vidas cotidianas na busca de sentido, como meio para compreender o que move e orienta as práticas sociais e a cotidianidade das pessoas. Requer sua familiarização com os significados culturais, valores, costumes e a estrutura social com quem convivem, buscando averiguar a racionalidade específica dos atos de indivíduos e de redes de indivíduos. Ainda, ter presente o jogo de espelhos que naturalmente é gerado na relação entre o investigador e os sujeitos estudados. Ter em mente que o conhecimento é algo 
desigualmente distribuído entre as pessoas, algo relacionado à estrutura social e aos papéis dos indivíduos. Por fim, estar ciente de que nem todas as portas estarão ou serão abertas ao diálogo, e que nem todas as pessoas manifestarão igual disponibilidade de expor suas ideias e opiniões, mais ainda quando for uma entrevista gravada. A etnografia é uma técnica de campo que exige períodos mais longos que outras técnicas de pesquisa.

7 Sobre essas e outras questões relativas ao fazer etnográfico, cf. Borofsky, 2019; Carvalho, 2004; Guber, 2012; Kawulich, 2005; Laplantine, 2004; Marcus e Cushman, 2003; Nader, 1969; Pels, 1997; Pujadas I Muños, 2010; Rappaport, 2000; Schwartzman, 1993; Souza Lima e Teixeira, 2010; Velho, 1994.

8 O RBC foi estruturado em nove tópicos: Percepções e significados acerca do PBF; Atividades produtivas e comerciais locais e sua relação com segurança alimentar; Acesso dos indígenas às unidades do Sistema Único de Assistência Social - Suas (Cras e Creas); Logística de pagamento e recebimento do benefício financeiro; Utilização do benefício financeiro; Cadastro Único; Condicionalidades; PBF e questões de gênero; Formas de relacionamento dos indígenas com representantes do poder público, comerciantes, e com demais pessoas e setores da sociedade local. Foi elaborado a partir das questões elaboradas pelas diferentes secretarias e coordenações do MDS envolvidas com a implementação e a avaliação do PBF, tendo sido validado durante a oficina de trabalho realizada em setembro de 2013, em Brasília/DF, com a participação dos sete antropólogos contratados para realizar os estudos de caso.

9 Com a utilização da noção de redes sociais, queremos nos referir, ainda, às relações e intercâmbios diretos e indiretos (interpessoais, interorganizacionais e sociotécnicos), interfamiliares e interétnicos, por meio dos quais fluem - no espaço e no tempo - objetos, informações, conhecimentos, além de ideias, conceitos e noções. A história da noção de rede nas ciências sociais remonta aos escritos de Saint-Simon no século XIX (Scherer-Warren, 2005), ganha projeção em meados do século XX com os estudos desenvolvidos no âmbito da tradição da antropologia social britânica (Feldman-Bianco, 1987), e alcança um desenvolvimento bem interessante com o antropólogo norte-americano Eric Wolf, ao evidenciar as relações entre o âmbito local e as instâncias regionais, nacionais e internacionais e seus múltiplos efeitos (Wolf, 2001, 2005; Feldman-Bianco G Ribeiro, 2003).

10 A família é definida no PBF como: "unidade nuclear, eventualmente ampliada por outros indivíduos que com ela possuam laços de parentesco ou de afinidade, que forme um grupo doméstico, vivendo sob o mesmo teto e que se mantém pela contribuição de seus membros" (lei n. 10.836/2004).

11 Aos interessados em aprofundar o tema, relacionando adaptação criativa - entendida como capacidade de inovação e como adaptabilidade estratégica às novas exigências históricas com processos de etnogênese, ver Bartolomé (2006), Herzfeld (2008), Hill (1996) e Oliveira (2004). 
BARTOLOMÉ, M. A. As etnogêneses: velhos atores e novos papeis no cenário cultural e político. Mana: Estudos em Antropologia Social, 12 (2): 39-68, 2006.

BOROFSKY, R. An Anthropology of Anthropology: is it time to shift paradigms? Kailua: Center for a Public Anthropology, 2019.

BOURDIEU, P. Compreender. In: BOURDIEU, P. (Org.). A Miséria do Mundo. Petrópolis: Vozes, 2011.

BOURDIEU, P. G WACQUANT, L. Interés, habitus, racionalidad. In: BOURDIEU, P. G WACQUANT, L. (Orgs.). Una Introducción a Sociología Reflexiva. Buenos Aires: Siglo XXI, 2005.

BRASIL. Ministério do Desenvolvimento Social e Combate à Fome. Manual de Gestão do Programa Bolsa Família. Brasília: MDS, 2013.

BRASIL. Ministério do Desenvolvimento Social e Agrário. Estudos Etnográficos sobre o Programa Bolsa Família entre Povos Indígenas. Brasília: Secretaria de Avaliação e Gestão da Informação do Ministério do Desenvolvimento Social e Agrário, 2016.

CAMPEllo, T. G NERI, M. C. (Orgs.). Programa Bolsa Família: uma década de inclusão e cidadania. Brasília: Ipea, 2013.

CARVALHO, C. Uma antropologia da imagem colonial: poder e figuração entre os Manjaco da Guiné Bissau. Anuário Antropológico/2002-2003: 225-250, 2004.

CARVAlHO, O. M. B. Políticas Públicas, Sustentabilidade Social e Povos Indígenas: os Xavante da terra indígena de Parabubure em Mato Grosso, 2010. Dissertação de Mestrado, Brasília: Centro de Desenvolvimento Sustentável, Universidade de Brasília.

CAStRo, J. A. G MODESTO, L. (Orgs.). Bolsa Família 2003-2010: avanços e desafios. 2 v. Brasília: Ipea, 2010.

FELDMAN-BIANCO, B. (Org.). Antropologia das Sociedades Contemporâneas: métodos. São Paulo: Global, 1987.

FELDMAN-BIANCO, B. G RIBEIRO, G. L. (Orgs.). Antropologia e Poder: contribuições de Eric Wolf. Campinas, Brasília, São Paulo: Editora da Unicamp, Editora da UnB, Imesp, 2003.

GUBER, R. La Etnografía: método, campo e reflexividad. Buenos Aires: Siglo XXI, 2012.

HERZFELD, M. Intimidade Cultural: poética social no Estado-Nação. Lisboa: Edições 70, 2008.

HILL, J. Introduction: ethnogenesis in the Americas, 1492-1992. In: HILL, J. (Ed.). History, Power and Identity: ethnogenesis in the Americas, 1492-1992. Iowa City: University of Iowa Press, 1996.

KAWULICH, B. B. La observación participante como método de recolección de datos. Forum Qualitative Sozialforschung, Forum Qualitative Social Research, 6(2), 43, 2005. Disponível em: <http://nbn-resolving.de/urn:nbn:de:0114-fqs0502430>. Acesso: 10 out. 2018. 
LAPLANTINE, F. A Descrição Etnográfica. São Paulo: Terceira Margem, 2004.

LONG, N. Sociología del Desarrollo: una perspectiva centrada en el actor. México: Centro de Investigación y Estudios Superiores en Antropología Social, El Colegio de San Luis, 2007.

MARCUS, G. E. G CUSHMAN, D. E. Las etnografías como texto. In: REYNOSO, C. (Ed.). EI Surgimiento de la Antropología Posmoderna. Barcelona: Editorial Gedisa, 2003.

NADER, L. Up the anthropologist: perspectives gained from studying up. In: HYMES, D. (Ed.). Reinventing Anthropology. New York: Random House, 1969.

OLIVEIRA, J. P. Uma etnologia dos índios misturados? Situação colonial, territorialização e fluxos culturais. In: OLIVEIRA, J. P. (Org.). A Viagem de Volta: etnicidade, política e reelaboração cultural no Nordeste indígena. Rio de Janeiro: Contra Capa, Laced, 2004.

PELS, P. The Anthropology of colonialism: culture, history, and the emergence of Western governmentality. Annual Review of Anthropology, 26: 163-183, 1997.

PUJADAS I MUÑOS, J. J. (Coord.) Etnografía. Barcelona: Editorial UOC, 2010.

RAPPAPORT, J. La Política de la Memoria: interpretación indígena de la historia en los Andes Colombianos. Popayán: Editorial Universidad del Cauca, 2000.

SCHERER-WARREN, I. Redes sociais: trajetórias e fronteiras. In: DIAS, L. C. G SILVEIRA, R. L. L. (Orgs.). Redes, Sociedades e Territórios. Santa Cruz do Sul: Edunisc, 2005.

SCHWARTZMAN, H. B. Ethnography in Organizations. Newbury Park: Sage Publications, 1993.

SOUZA LIMA, A. C. G TEIXEIRA, C. C. A antropologia da administração e da governança no Brasil: áreas temáticas ou ponto de dispersão. In: MARTINS, C. B. G DUARTE, L. F. D. (Coords.). Horizontes das Ciências Sociais no Brasil. São Paulo: Anpocs, 2010.

VELHO, G. Observando o familiar. In: VELHO, G. Individualismo e Cultura: notas para uma antropologia da sociedade contemporânea. Rio de Janeiro: Jorge Zahar, 1994.

VERDUM, R. (Org.). Assistência Técnica e Financeira para o Desenvolvimento Indígena. Brasília, Rio de Janeiro: Nead, Contra Capa, 2005.

VERDUM, R., ARAÚJO, A. L. O. (Org.). Experiências de Assistência Técnica e Extensão Rural junto aos Povos Indígenas: o desafio da interculturalidade. Brasília: Nead, 2010.

WOLF, E. Figurar el Poder: ideologías de dominación y crisis. México: Centro de Investigaciones y Estudios Superiores en Antropología Social, 2001.

WOLF, E. A Europa e os Povos Sem História. São Paulo: Editora da USP, 2005. 
Dados Censitários em Contexto 


\section{Indígenas em Belo Horizonte: o uso dos dados de setores censitários para estudos intraurbanos}

Este capítulo tem dois objetivos principais: avaliar o potencial de uso dos dados do Censo Demográfico 2010 do Instituto Brasileiro de Geografia e Estatística (IBGE) para estudos intraurbanos e, concomitantemente, fazer uma análise socioespacial dos locais de moradia dos indígenas no município de Belo Horizonte, utilizando os setores censitários como unidade de análise. Utiliza-se a base de dados denominada Agregados por Setor Censitário, base que contém o somatório das características dos moradores de cada setor censitário para uma gama de variáveis selecionadas pelo instituto.

Inicialmente, faz-se uma reflexão metodológica sobre as potencialidades e limitações de utilização de informações apresentadas no tipo de formato adotado pelo IBGE para divulgação dos dados por setor censitário. Em seguida, avalia-se a utilidade dessa base de dados para estudos socioespaciais, na escala intramunicipal, a partir de um experimento empírico que qualifica os locais de moradia daqueles que foram declarados indígenas no último censo.

Segundo o último levantamento censitário, 39\% dos indígenas do Brasil residiam em áreas urbanas no país (IBGE, 2011). Embora esse percentual seja inferior ao captado pelo Censo 2000 (51\% dos indígenas), ainda assim representa um número considerável de indígenas (315 mil) residindo nesses espaços. Também é importante destacar que, em 2010, cerca de metade dos indígenas que viviam em áreas urbanas não tinham nascido nos municípios em que residiam, o que mostra o papel preponderante da migração para a presença de indígenas em contextos urbanos.

Na primeira seção, estabelece-se um diálogo com alguns estudos que tratam de indígenas vivendo em ambientes urbanos, de forma a introduzir o tema da pesquisa de forma conceitual. Na segunda, apresentam-se a base de dados utilizada, avaliando suas possibilidades de uso em análises espaciais, e o método de estudo adotado. Na terceira seção, discutem-se os resultados e, a seguir, apresentam-se as considerações finais do trabalho.

Espera-se, com base no exercício realizado, avaliar o potencial de uso das informações censitárias para estudar populações minoritárias em ambientes urbanos, 
assim como para dar visibilidade a um fenômeno complexo e importante que ainda se mostra relativamente pouco conhecido dos estudos demográficos.

\section{Os indígenas e a cidade}

A associação entre indígena e cidade pode causar certo estranhamento entre os não ambientados ao tema, no sentido de "haver algo fora do lugar". Tanto no imaginário de grande parte da população (principalmente da que vive fora da região Norte do país) quanto em abordagens acadêmicas menos informadas, é atribuído ao indígena um espaço de vida relativamente fixo que se limita, via de regra, às reservas indígenas ou áreas florestais. Se utilizarmos a bipartição - um tanto quanto grosseira - do território entre áreas urbanas e rurais, aos indígenas seria atribuído, pelo imaginário menos informado, uma vida típica das áreas rurais. Isso estaria ligado a um tipo de essência atribuída, equivocadamente, aos povos indígenas (Cunha, 2012; Oliveira, 2016). A perda dessa essência remeteria a um desencontro entre o indivíduo e o seu espaço de vida, incidindo claramente sobre uma dimensão espacial.

Até mesmo no âmbito da antropologia - área em que tradicionalmente tem-se produzido o maior número de estudos sobre povos indígenas -, há críticas de que a presença dos indígenas na cidade, apesar de ser um fenômeno antigo, demora a ganhar relevância em termos de produção acadêmica (Nunes, 2010). Esses silêncios e esquecimentos sobre o papel do indígena na história nacional - enfatizados exaustivamente no trabalho de Oliveira (2016) - talvez sejam os responsáveis pela ideia de desencaixe espacial entre o indígena e a cidade.

Os resultados dos últimos três censos demográficos lançam nova luz sobre a questão. Foram registrados 71 mil indígenas vivendo em cidades em 1991, 383 mil em 2000 e 315 mil em 2010, representando 24\%, 52\% e 39\% dos declarados indígenas em cada censo, respectivamente. Em que pesem as variações entre os censos, os números são expressivos e conferem visibilidade ao fenômeno. Além disso, os resultados mostram que a presença de indígenas em cidades é um fenômeno de abrangência nacional. Embora a forma de captação dos indígenas em pesquisas domiciliares de natureza quantitativa seja um tema complexo e apresente certas limitações à interpretação dos números, é inegável a importância que o censo assume para estudos sobre indígenas no país e para a elaboração de políticas públicas voltadas para essa população.

As informações censitárias, por serem passíveis de agregação em nível nacional, facilitam deslizes interpretativos e generalizações incorretas, podendo levar à homogeneização de algo bastante heterogêneo e diversificado. 
Uma análise mais detalhada dos próprios dados censitários - assim como o conhecimento produzido por outras fontes de informação e diferentes métodos de investigação - mostram a elevada diversidade entre as populações indígenas do país em geral, o que não é diferente no tocante à presença indígena nos centros urbanos. Há cidades com um número expressivo de indígenas, como os municípios de São Gabriel da Cachoeira, no Amazonas, cujo prefeito, em 2018, ano que o este estudo foi realizado, era indígena, do povo Ticuna, assim como São João das Missões, em Minas Gerais, cujo prefeito era indígena Xacriabá. Há também cidades próximas a reservas, como no caso dos indígenas de Canarana documentado por Horta (2017), além do conhecido estudo sobre os Terena realizado por Oliveira (1968), nas cidades de Aquidauana, Miranda e Campo Grande, na década de 1950. Há ainda o caso das grandes metrópoles da região Sudeste, por exemplo, onde a visibilidade dessas populações é menor, apesar da sua importância histórica na ocasião do nascimento dessas cidades e da continuada presença, como ocorre com os Pankararu, que há décadas realizam contínuos deslocamentos entre o interior de Pernambuco e a cidade de São Paulo (Estanislau, 2014).

É importante destacar que a presença de indígenas em cidades é considerada um tema de estudo emergente não só no Brasil, mas também em todo o mundo. Mereceu destaque no relatório produzido pelo Fórum Permanente para as Populações Indígenas das Nações Unidas, intitulado State of the World's Indigenous Peoples (UN, 2009), assim como em publicação da Comissão Econômica para América Latina e Caribe (Cepal, 2014).

\section{Desafios para estudos sobre populações indígenas em cidades}

Os dados censitários têm sido cada vez mais utilizados como fonte de informação sobre a população indígena do Brasil. Desde a (re)inserção da categoria "indígena" no quesito de cor ou raça do Censo 1991, o número de estudos de natureza quantitativa sobre os indígenas vem crescendo de forma significativa no país. A coletânea organizada por Pagliaro, Azevedo e Santos (2005), as publicações do IBGE referentes aos indígenas em 2005 e 2012 e o dossiê da Revista Brasileira de Estudos de População (n. 33, v. 2, 2016) são exemplos do vigor que a temática vem ganhando no país recentemente.

Embora muito se tenha avançado nos últimos anos em termos de análises censitárias sobre populações indígenas, são poucos os estudos que tratam dos indígenas residentes em áreas urbanas. A maior parte da produção científica sobre este tema é de natureza qualitativa e tem no trabalho de campo, em especial nas etnografias, a principal fonte de informações. 
Nos estudos históricos ou etnográficos, geralmente delimita-se o objeto da pesquisa previamente para, em seguida, serem produzidas informações a seu respeito. Embora isso também possa ser feito com base nos dados dos censos, o caminho metodológico comumente adotado é o oposto da abordagem anterior: parte-se da base de dados para tentar - após as informações terem sido produzidas e divulgadas - entender quais indivíduos foram captados (estatisticamente capturados) e quais são suas características. Com os censos, partimos do dado para identificar o grupo, ao invés de partir do grupo para construir a informação. Se, no primeiro caminho, sabe-se quem são os indígenas e o desafio passa a ser entendê-los, no segundo, é mais fácil descrevê-los do que saber quem realmente são.

Por um lado, são justamente nos dados para áreas urbanas que os censos nos brindam com suas maiores novidades (Oliveira, 2016), por outro, são os dados que nos colocam frente aos maiores desafios interpretativos.

De partida, somos levados a refletir sobre qual situação particular ou coletiva faz indivíduos serem incluídos na categoria genérica "indígena", ou excluídos dessa classificação, com base em respostas a uma pergunta sobre cor ou raça dos moradores do domicílio (resposta que pode ser dada tanto pelo próprio indivíduos como por outro morador do domicílio, importante frisar). É um processo realizado em rápidas entrevistas que cobrem todo o país em um curto período de tempo, geralmente entre três e quatro meses. Nas terras indígenas cadastradas nas bases do IBGE, ainda há uma outra pergunta que daria uma segunda chance, estatisticamente falando, de classificar o indivíduo como indígena, uma espécie de pergunta de cobertura feita para os que não foram declarados como indígenas nesses locais: é perguntado se o indivíduo se considera (ou é considerado pelo informante do domicílio) indígena. Em relação ao município de Belo Horizonte, que não tem nenhuma área indígena demarcada, a única forma direta de identificação é por meio da pergunta sobre cor ou raça. A simples enumeração das opções de resposta (branca, preta, parda, amarela ou indígena) do quesito de cor ou raça já dá indícios de que pode haver omissão, confusão e sobreposição de respostas para um mesmo indivíduo.

Longe de desqualificar a informação, o debate em torno de seus processos de produção visa a delimitar precisamente o objeto de que tratam essas informações, qualificando-as ainda mais como instrumento de investigação. À medida que conhecemos a forma como foi produzida a informação aumenta a nossa segurança de que a mesma se refere a algum evento cuja manifestação foi capturada por uma operação de coleta. Os conceitos que norteiam o desenho do questionário dos censos demográficos, contudo, são baseados em noções de indivíduos típicos, que muitas vezes se encontram distanciados da realidade em que vivem muitos povos indígenas em termos de habitação, mobilidade espacial, relações de parentesco, práticas religiosas etc. Embora os questionários dos censos estejam, a cada operação, mais 
sensíveis a formas de organização da vida de alguns povos indígenas, eles captarão melhor as características daqueles que mais se enquadram nas opções previamente definidas do instrumento de pesquisa (Campos G Estanislau, 2016). No âmbito deste estudo, que trata dos indígenas residentes em uma grande metrópole da região Sudeste, acredita-se que a aplicação dos questionários não tenha encontrado sérios problemas de entendimento. O que não se sabe, entretanto, é a gama de fatores que influenciaram os moradores de Belo Horizonte a classificarem a si mesmos ou aos outros moradores dos domicílios como indígenas.

Este capítulo pretende contribuir para o preenchimento dessa lacuna, explorando os dados dos agregados dos setores censitários do Censo 2010, utilizando o exemplo do município de Belo Horizonte.

\section{Análise da documentação que acompanha a base de dados}

Inicialmente, é importante lembrar que existem diferentes caminhos para acessar os dados do censo. Pode-se, por exemplo, utilizar as publicações temáticas divulgadas pelo IBGE ou acessar o Sistema IBGE de Recuperação Automática (Sidra), disponibilizado pelo IBGE para realização limitada de consultas. Pode-se também usar os microdados da amostra, com total liberdade de cruzamentos e tabulações, mas com limitações amostrais e de desagregação espacial. Para as informações do universo, que englobam as variáveis comuns aos questionários básico e amostral, é possível realizar algumas tabulações com base nos dados do Banco Multidimensional de Estatísticas (BME), que, no entanto, não permitem utilizar um espacial detalhado, no nível de setor censitário, por exemplo.

Cada um desses formatos apresenta peculiaridades que direcionam as possibilidades de aplicação e a utilização de métodos de análise, sendo geralmente complementares em termos de agregação das informações e escopo territorial. Embora essa estratégia de fragmentação das formas de divulgação dos resultados dos censos amplie a gama de interpretações dos mesmos, a impossibilidade de compatibilização dos resultados obtidos com o uso de diferentes bases de dados é uma limitação a uma apreensão - no que poderíamos chamar de uma totalidade estatística - da realidade captada pelo instrumento.

Outra forma de divulgação do censo são os Agregados por Setor Censitário, base de dados acessível no site do IBGE para os últimos dois censos, cujos resultados das somas de diversas variáveis para cada setor censitário são divulgados em planilhas. São dados ainda pouco utilizados para estudos de populações indígenas, embora tenham elevado potencial analítico para os que querem fazer análises socioespaciais, como qualificar os locais de residência dos indígenas.

No documento "Base de informações do Censo Demográfico 2010: resultados do universo por setor censitário" (IBGE, 2011), disponibilizado no site do IBGE, 
estão descritas as características metodológicas da base de dados sobre as quais serão tecidas considerações em termos de potencial de uso e limitações.

Segundo o documento, os dados remetem ao universo da população, ou seja, reúnem informações de todos os domicílios e pessoas investigadas nos dois tipos de questionário utilizados nos censos: questionários básico e amostral (IBGE, 2011). Isso traz uma vantagem para a utilização dos dados, em relação, por exemplo, aos microdados da amostra, pois não há restrição amostral advinda da variação das estimativas, possibilitando realizar análises em escalas espaciais reduzidas, com altíssimo detalhamento espacial como para setores censitários. O munícipio de Belo Horizonte, por exemplo, foi dividido em quase 4 mil setores.

Embora o dimensionamento do setor priorize a otimização do processo de coleta, o IBGE considera as informações dos setores como uma possibilidade de disseminação de informações georreferenciadas. Contudo, vale ressaltar que, por não ter finalidade exclusivamente analítica, continua apresentando um recorte espacial que nem sempre é aquele do qual o pesquisador necessita. Áreas muito heterogêneas podem fazer com que, em um mesmo setor, haja domicílios com características bastante diferentes. Como os dados divulgados referem-se ao somatório das informações coletadas no setor, não é possível considerar essa heterogeneidade nas análises.

Conforme será discutido na próxima seção, o pequeno número de indígenas presentes nos setores algumas vezes deixa dúvidas se as informações desses indivíduos estariam próximas da média dos outros moradores do setor (representadas pelos somatórios divulgados para cada variável) ou se estariam distantes desses valores.

As informações são divulgadas em cerca de três mil variáveis, que nada mais são do que cruzamentos predefinidos entre as poucas - mas não por isso desimportantes - variáveis selecionadas. Essas variáveis abrangem as seguintes características da população: sexo, idade, cor ou raça, condição no domicílio, pessoas responsáveis pelo domicílio, alfabetização, renda, registro de nascimento das crianças de até 10 anos de idade e características dos domicílios particulares e de seu entorno.

O último ponto a ser destacado refere-se ao impacto da confidencialidade das informações do censo no formato de divulgação de seus resultados. No intuito de garantir proteção dos dados dos informantes, o IBGE utiliza estratégias para que indivíduos não possam ser localizados quando se trabalha com informações muito desagregadas. Assim, em todos os setores com menos de cinco domicílios particulares permanentes, foram omitidos os valores da maioria das variáveis. Isso fez com que aproximadamente $2 \%$ dos setores do país tivessem dados omitidos. Em nosso trabalho, 65 setores precisaram ser excluídos da análise por causa desse motivo. 
Estratégia de análise

O município de Belo Horizonte tem 3.895 setores censitários. Dentre eles, 3.830 foram utilizados na análise. Um total de 57 setores não apresentava informação na base de dados sobre a quantidade de indígenas residentes, além de oito setores não terem informações para as demais variáveis selecionadas.

Primeiramente, agrupamos os setores censitários de Belo Horizonte pela quantidade de indígenas residentes em cada um deles. Em seguida, as informações foram organizadas a fim de realizar análises estatísticas e mapeamento coroplético. ${ }^{1}$

As análises estatísticas foram feitas com base no cálculo dos coeficientes de correlação linear entre o número de indígenas por setor (categoria principal) e algumas variáveis socioeconômicas disponibilizadas na base de dados. As variáveis foram agrupadas por cada categoria principal, calculando-se o valor médio de cada variável em cada categoria. São elas: 1) média do rendimento nominal mensal; 2) média de moradores dos domicílios; 3) percentual de responsáveis alfabetizados; 4) percentual de domicílios água encanada; 5) percentual de domicílios com coleta de lixo; 6) percentual de residentes brancos; 7) percentual de residentes pretos; 8) percentual de residentes pardos.

Para a representação espacial dos setores censitários, conforme a quantidade de indígenas, foram criados mapas de localização dos setores segundo a quantidade de indígenas, fazendo-se, em seguida, a tabulação dessas informações com os dados de rendimento nominal mensal.

Com o objetivo de aprofundar um pouco mais a análise dos locais de residência dos indígenas no município, foram utilizadas, ainda com base nos agregados por setores censitários, as informações relativas às características urbanísticas do entorno dos domicílios. Esses dados, coletados pelo IBGE pela primeira vez em 2010, foram obtidos via observação das características dos logradouros das áreas urbanas do país, na fase de pré-coleta da operação (IBGE, 2011), ou seja, não advêm das entrevistas realizadas nos domicílios. Constituem, portanto, uma base de dados alternativa e complementar ao rico acervo censitário.

Os dados referem-se a aspectos da infraestrutura urbana, com destaque para as dimensões circulação e ambiente. Especificamente, foram observados: identificação do logradouro; iluminação pública; pavimentação; calçada; meio-fio/ guia; bueiro/boca de lobo; rampa para cadeirante; arborização; esgoto a céu aberto e lixo acumulado nos logradouros (IBGE, 2011).

Cabe ressaltar que, nas áreas de favela, pelo IBGE denominadas "aglomerados subnormais", a investigação teve escopo limitado em virtude da impossibilidade de se identificarem quadras ou quarteirões, pelos conceitos do instituto.

Com base em sete variáveis de condições do entorno dos domicílios, foi calculada a proporção de moradores em uma determinada condição sobre o total de moradores do setor, a saber, a proporção de moradores em: 1) ruas sem iluminação 
pública; 2) ruas sem pavimentação; 3) ruas sem boca de lobo; 4) ruas sem meio-fio; 5) ruas sem calçada; 6) ruas com esgoto a céu aberto; 7) ruas com lixo acumulado.

Utilizou-se uma análise de componentes principais para explorar o comportamento das sete variáveis selecionadas. A variabilidade dos dados foi agrupada em dois eixos que explicaram 60\% da variabilidade total, permitindo o agrupamento destas em duas dimensões: eixo 1 (ruas sem boca de lobo, sem pavimentação, sem meio-fio e sem iluminação); eixo 2 (ruas com lixo acumulado e com esgoto a céu aberto).

Foi construído, então, um índice de condições do entorno, para o qual foram utilizadas as duas dimensões identificadas na análise de componentes principais, representada pelo valor médio das variáveis em cada setor censitário:

Dimensão $1=\frac{(\text { s/iluminação }+ \text { s/boca delobo }+ \text { s/pavimentação }+ \text { s/calçamento }+ \text { s/meio fio })}{5}$

Dimensão $2=\frac{\text { (c/esgoto exposto }+ \text { c/lixo acumulado })}{2}$

Cada dimensão varia entre 0 (melhor condição) e 1 (pior condição). Para integrar as duas dimensões em um índice temático, optou-se por utilizar a distância euclidiana entre a posição de cada setor em um plano cartesiano, no qual cada dimensão representa um eixo $(\mathrm{x}, \mathrm{Y})$. A integração foi possível utilizando o teorema de Pitágoras, segundo a proposta de Ligeiro e colaboradores (2013), na qual, quanto mais próximo da origem, melhor a condição do entorno no setor censitário; quanto mais distante, pior a condição.

Desse modo, chegou-se ao Índice de Condições do Entorno (ICE), ${ }^{2}$ representado por:

$\mathrm{ICE}=\left(\text { Dimensão1 }^{2}+\text { Dimensão2 }^{2}\right)^{(1 / 2)}$

As análises estatísticas foram realizadas comparando-se as diferenças entre o ICE nos setores com mais indígenas do município e os demais setores, por meio do teste de Mann-Whitney, que compara se um grupo de setores apresenta a tendência de ter maiores valores de ICE em relação ao outro. Em um primeiro momento, testou-se a diferença nas condições do entorno através do ICE entre os setores com mais de dez indígenas e todos os demais setores urbanos; em um segundo momento, testou-se a diferença entre os setores com indígenas e os seus vizinhos de segunda ordem - os "vizinhos dos vizinhos" (Besag, 1974). 


\section{Resultados}

Com base nas informações do BME, vemos que 3.477 indivíduos foram declarados como indígenas em Belo Horizonte - 44\% homens e 56\% mulheres. Noventa e um por cento eram alfabetizados e 68\% residiam em domicílios próprios. A maior parte morava em domicílios com quatro moradores (25\%), seguidos dos que viviam em domicílios com três moradores (22\%).

As informações dos agregados por setor censitário são apresentadas na Figura 1, que mostra a distribuição espacial dos setores com pelo menos um indígena no município. Salta aos olhos o fato de que os indígenas estão distribuídos por praticamente todo o município. Entretanto, se observarmos a gradação relativa ao número de indígenas por setor, vemos que há um sensível deslocamento dos setores com relativamente mais indígenas para regiões mais afastadas do centro do mapa.

Figura 1 - Número de indígenas por setor censitário - Belo Horizonte - 2010

Número de indígenas

$0,0-0,0$

$0,0-3,0$

$3,0-8,0$

$8,0-15,0$

$15,0-39,0$

Fonte: IBGE, 2011.

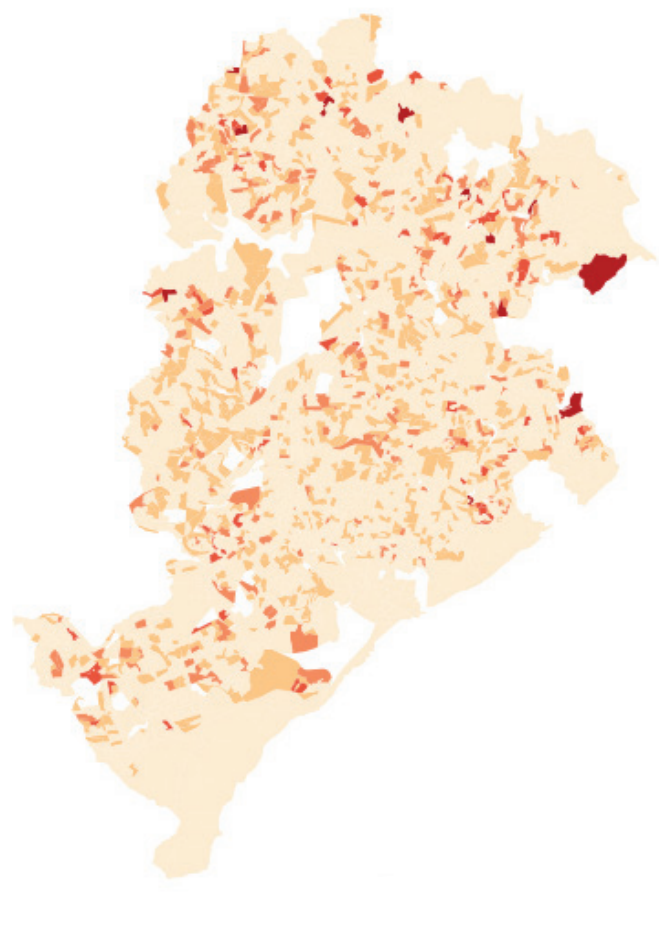

A fim de aprofundar a investigação, procuramos entender o que diferenciava os setores com ou sem indígenas, assim como os que tinham diversas quantidades de indígenas. Foi feita, então, uma análise de correlação linear entre o número de indígenas nos setores e as variáveis selecionadas para o estudo (Tabela 1). 
Em primeiro lugar, é importante destacar que, em $72 \%$ dos setores censitários de Belo Horizonte, não havia nenhum indígena. A análise das informações apresentadas mostra que, embora numericamente o fenômeno seja diminuto, ele está presente em praticamente todo o município. Ainda assim, entre os setores com indígenas, 84\% tinham cinco ou menos indivíduos declarados nessa categoria.

Com o aumento do número de indígenas, é significante o decréscimo do rendimento nominal mensal e do percentual de responsáveis alfabetizados, além de uma pequena redução na cobertura por água encanada. Entretanto, há um aumento na média de moradores por domicílio, além de uma pequena elevação da cobertura de coleta de lixo. Em relação às outras categorias de cor ou raça dos moradores, o aumento do número de indígenas está sensivelmente correlacionado à diminuição do percentual de brancos do setor e ao aumento de residentes pardos e, principalmente, negros.

A variável que apresentou a maior correlação foi o rendimento nominal mensal médio do setor, de - 0,78. Isso mostra que o aumento no número de indígenas nos setores é acompanhado por uma forte diminuição do rendimento médio do setor.

O Gráfico 1 ilustra a relação entre o número de indígenas e o rendimento nominal médio, onde podemos observar quedas significativas de rendimento. O setor com 17 indígenas é o único que destoa da tendência apresentada no gráfico. Faremos uma análise específica deste setor ao final da seção.

O fato mais interessante a destacar, entretanto, é que não há praticamente nenhuma diferença entre o rendimento médio dos setores em que não há indígenas daqueles com muitos poucos indígenas. A correlação negativa só se torna visível a partir de cinco indígenas, quando a renda caí continuamente (Tabela 1 e Gráfico 1). 
Tabela 1 - Distribuição dos setores censitários por número de indígenas no setor, segundo variáveis selecionadas - Belo Horizonte 2010

\begin{tabular}{|c|c|c|c|c|c|c|c|c|c|}
\hline \multirow[b]{3}{*}{$\begin{array}{l}\text { Indígenas } \\
\text { no setor } \\
\text { (categorias) }\end{array}$} & \multicolumn{9}{|c|}{ Setores censitários } \\
\hline & \multirow[b]{2}{*}{ Quantidade } & \multicolumn{8}{|c|}{ Valores médios da categoria } \\
\hline & & $\begin{array}{c}\text { Rendimento } \\
\text { nominal } \\
\text { mensal }\end{array}$ & $\begin{array}{l}\text { Moradores } \\
\text { por } \\
\text { domicílio }\end{array}$ & $\begin{array}{l}\text { \% de } \\
\text { responsáveis } \\
\text { alfabetizados }\end{array}$ & $\begin{array}{c}\text { \% de } \\
\text { cobertura } \\
\text { água } \\
\text { encanada }\end{array}$ & $\begin{array}{c}\% \text { de } \\
\text { cobertura } \\
\text { coleta de } \\
\text { lixo }\end{array}$ & $\begin{array}{l}\text { \% de } \\
\text { residentes } \\
\text { brancos }\end{array}$ & $\begin{array}{l}\% \text { de } \\
\text { residentes } \\
\text { pretos }\end{array}$ & $\begin{array}{l}\text { \% de } \\
\text { residentes } \\
\text { pardos }\end{array}$ \\
\hline 0 & 2.753 & $1.263,80$ & 3,10 & 96,5 & 99,7 & 99,4 & 47,6 & 9,8 & 41,6 \\
\hline 1 & 450 & $1.286,09$ & 3,02 & 97,2 & 99,7 & 99,5 & 49,7 & 9,0 & 40,0 \\
\hline 2 & 219 & $1.105,32$ & 3,09 & 96,6 & 99,8 & 99,6 & 46,4 & 10,2 & 41,9 \\
\hline 3 & 102 & 997,32 & 3,15 & 95,9 & 99,7 & 99,9 & 43,1 & 11,2 & 43,7 \\
\hline 4 & 72 & $1.047,02$ & 3,10 & 96,9 & 99,8 & 99,7 & 45,1 & 10,6 & 42,3 \\
\hline 5 & 57 & 870,55 & 3,11 & 95,7 & 99,8 & 99,9 & 40,9 & 11,8 & 44,7 \\
\hline 6 & 41 & 824,84 & 3,23 & 95,5 & 99,8 & 99,7 & 40,2 & 13,2 & 44,2 \\
\hline 7 & 34 & 715,15 & 3,23 & 95,1 & 99,8 & 99,8 & 36,8 & 13,8 & 46,7 \\
\hline 8 & 19 & 709,54 & 3,30 & 94,8 & 99,8 & 99,4 & 37,4 & 13,7 & 45,6 \\
\hline 9 & 15 & 581,65 & 3,36 & 93,2 & 99,7 & 98,6 & 35,0 & 14,1 & 47,9 \\
\hline 10 & 17 & 606,96 & 3,23 & 93,8 & 99,8 & 99,9 & 35,1 & 12,8 & 49,1 \\
\hline 11 & 8 & 625,79 & 3,24 & 95,4 & 99,5 & 99,9 & 36,8 & 12,9 & 47,4 \\
\hline 12 & 12 & 624,66 & 3,35 & 92,3 & 99,9 & 99,9 & 31,7 & 15,9 & 49,5 \\
\hline 13 & 9 & 633,64 & 3,30 & 93,7 & 100,0 & 99,9 & 33,0 & 15,6 & 47,3 \\
\hline 14 & 8 & 421,59 & 3,52 & 89,4 & 99,8 & 99,6 & 29,6 & 15,2 & 50,6 \\
\hline 15 & 2 & 428,31 & 3,71 & 86,2 & 99,7 & 99,8 & 24,0 & 22,9 & 50,5 \\
\hline 16 & 1 & 312,42 & 4,06 & 90,5 & 99,8 & 99,0 & 21,9 & 27,6 & 47,0 \\
\hline 17 & 1 & 847,29 & 3,23 & 96,4 & 100,0 & 100,0 & 41,4 & 14,3 & 39,8 \\
\hline 18 & 2 & 590,93 & 3,27 & 95,7 & 99,7 & 99,5 & 34,3 & 13,0 & 49,8 \\
\hline 19 & 1 & 476,42 & 3,55 & 94,4 & 100,0 & 100,0 & 31,2 & 15,0 & 47,0 \\
\hline 20 & 1 & 518,04 & 3,27 & 92,3 & 99,5 & 100,0 & 24,5 & 11,8 & 57,9 \\
\hline 21 & 1 & 537,73 & 3,57 & 96,2 & 99,9 & 99,6 & 27,7 & 15,9 & 53,5 \\
\hline 23 & 1 & 487,31 & 3,56 & 92,8 & 99,8 & 100,0 & 31,1 & 14,9 & 49,9 \\
\hline 24 & 1 & 310,47 & 3,68 & 86,0 & 99,6 & 99,6 & 25,1 & 20,6 & 49,0 \\
\hline 25 & 2 & 531,02 & 3,36 & 95,4 & 99,8 & 98,5 & 30,0 & 16,1 & 48,8 \\
\hline 39 & 1 & 402,76 & 3,60 & 81,6 & 99,6 & 100,0 & 26,9 & 25,6 & 40,2 \\
\hline \multicolumn{2}{|c|}{$\begin{array}{l}\text { Coeficiente de correlação } \\
\text { lienar com quantidade de } \\
\text { indígenas no setor }\end{array}$} & $-0,78$ & 0,64 & $-0,67$ & $-0,06$ & 0,05 & $-0,77$ & 0,68 & 0,35 \\
\hline
\end{tabular}

Fonte: IBGE, 2011. 
Gráfico 1 - Rendimento nominal mensal médio dos setores segundo a quantidade de indígenas residentes - Belo Horizonte - 2010

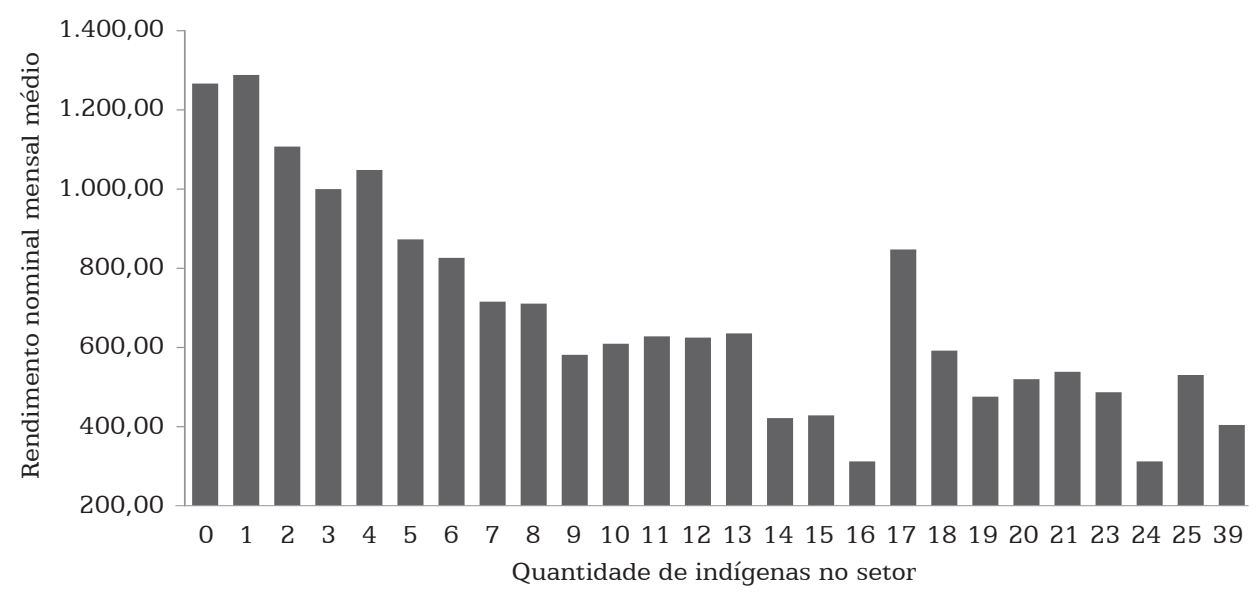

Fonte: IBGE, 2011.

O fato de não haver diferença significativa entre os setores com nenhum ou com poucos indígenas em termos das variáveis selecionadas é um ponto forte deste estudo. A renda média, por exemplo, é praticamente a mesma entre as categorias 0 ou 1 indígena. Não sabemos quais indivíduos foram declarados como indígenas nesses setores, mas é provável que se assemelhem mais com os não indígenas residentes nos mesmos locais do que com os indígenas residentes em setores nos quais estão relativamente um pouco mais concentrados e que, no caso da renda, têm valores bem inferiores.

A Figura 2 mostra a localização dos setores com 15 indígenas ou mais juntamente com as faixas de rendimento médio mensal dos setores.

Observamos a concentração dos setores com mais indígenas na região mais clara do mapa, onde estão as rendas mais baixas. Os setores com muitos indígenas localizam-se numa espécie de arco externo às regiões de renda mais alta. Em contrapartida, os setores com poucos indígenas estão espalhados por uma área mais ampla do município, em que a renda é relativamente mais elevada. 
Figura 2 - Número de indígenas residentes e rendimento médio mensal dos setores censitários - Belo Horizonte - 2010
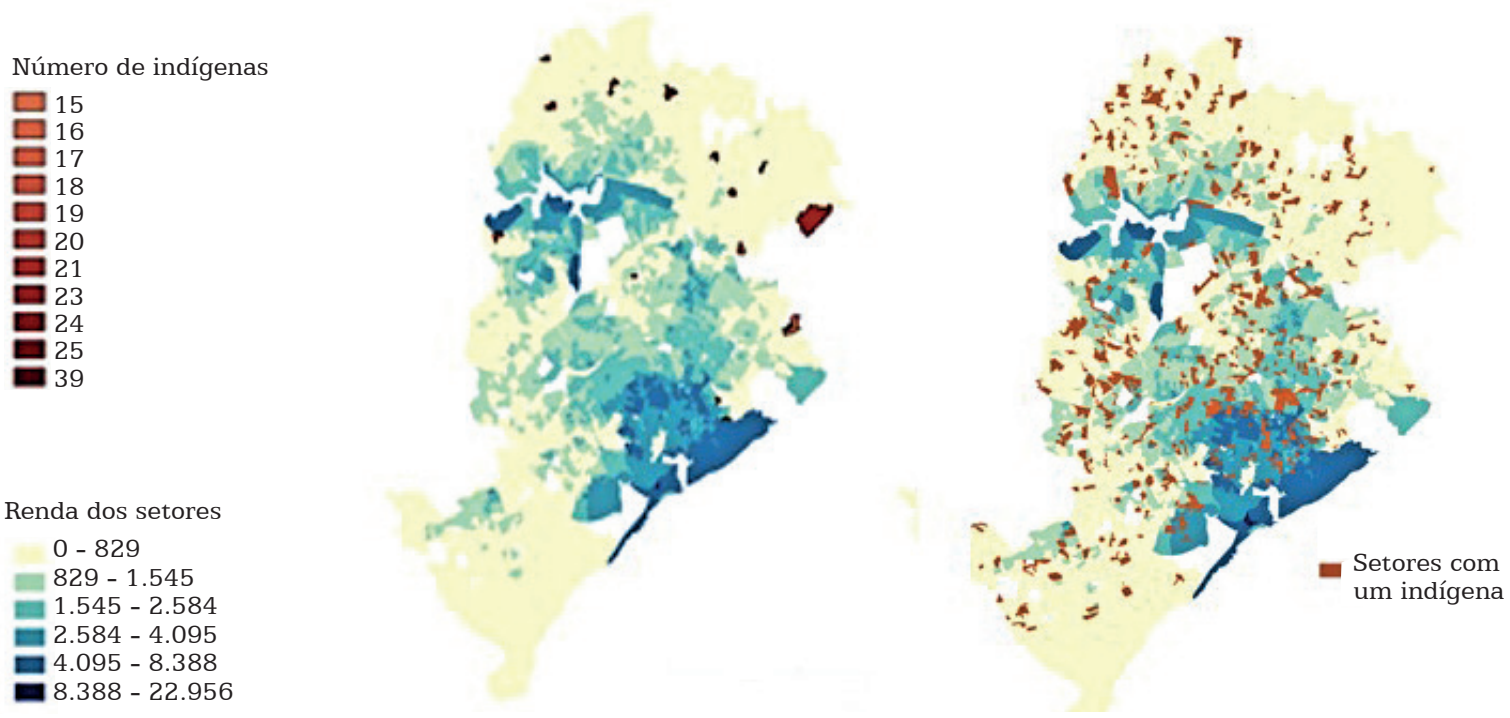

Fonte: IBGE, 2011.

Foi realizada também uma análise qualitativa complementar, com base nas imagens do Google Earth e Google Street View para os setores com 15 ou mais indígenas (dados não apresentados). Constatamos que a maioria dos setores com 15 indígenas é predominantemente residencial, com baixa densidade de construções, ou seja, compostos em sua maioria por casas, e alguns por prédios de poucos andares. Três setores fogem dessa regra, com 17, 18 e 23 indígenas, que apresentam uma concentração de comércio em um ponto específico do setor. No caso do setor com 17 indígenas, há um amplo comércio de peças e acessórios automotivos que talvez explique a renda destoante em relação às categorias vizinhas, conforme apresentado no Gráfico 1.

Ao observarmos os equipamentos públicos, constatamos que mais da metade dos setores (oito) tinha escolas e creches. Foi observado também um Centro de Referência de Assistência Social (Cras) no setor com 16 indígenas, localizado no bairro Granja de Freitas, região limítrofe da capital mineira. Nos outros seis setores, não foram encontrados equipamentos públicos próximos. É interessante notar que em dois setores não havia pontos de ônibus.

Os resultados das análises estatísticas espaciais são apresentados em seguida.

Os valores medianos dos ICE entre os setores com mais de dez indígenas e todos os demais setores urbanos do município de Belo Horizonte foi significativa ( $p<0,001$ ), ou seja, há uma tendência dos valores dos setores com mais de dez 
indígenas de apresentarem maiores valores de ICE, associando-os às condições de entorno menos estruturadas do ponto de vista urbano. A análise, repetida utilizando os setores com mais de dez indígenas e seus vizinhos de segunda ordem, também apresentou valores significativos $(p<0,05)$.

Estes resultados mostram que as condições do entorno dos setores em que os indígenas vivem é pior em relação aos demais setores de Belo Horizonte e em relação aos seus vizinhos de segunda ordem.

\section{Considerações finais}

A presença dos indígenas nas cidades brasileiras é um fenômeno complexo e com implicações importantes, embora muitas vezes tenha sido ignorado ou mal compreendido. As informações dos censos demográficos lançam nova luz sobre a questão, ao mostrarem que um volume considerável de indígenas vive em áreas urbanas.

As análises realizadas atestam a utilidade da base de dados dos setores censitários para estudos de indígenas em espaços urbanos, conferindo grande potencial interpretativo para uma escala bastante reduzida.

Os resultados mostram pelo menos dois tipos de indígenas que emergem dos dados do censo em contextos urbanos. Há aqueles que viviam espacialmente isolados de outros (no sentido estrito de não haver outros indígenas residindo no mesmo espaço, embora possam compartilhar a própria residência com indivíduos de outra cor ou raça) em setores censitários de alta renda, alto nível de escolarização e elevado percentual de brancos residentes. Entretanto, há um pequeno grupo de indígenas que vivia em setores com mais indígenas, setores que apresentavam baixa renda, maior nível de responsáveis analfabetos e maior percentual de população preta e parda. Cabe destacar, também, que os setores com mais indígenas localizam-se nas áreas cujo entorno estão em piores condições urbanísticas, em relação aos demais setores urbanos em Belo Horizonte. Mesmo analisando o entorno imediato, esses setores também apresentam as piores condições, apontando para a vulnerabilidade dessas populações no que tange à habitação em Belo Horizonte.

Com base no exercício realizado, espera-se contribuir para a ampliação do uso de informações censitárias para estudos de populações minoritárias em ambientes urbanos, assim como para enfrentar a invisibilidade estatística dessa população. 


\section{Notas}

1 Os mapas coropléticos são elaborados com dados quantitativos e apresentam sua legenda ordenada em classes conforme as regras próprias de utilização do valor visual variável por meio de tonalidades de cores, ou ainda, de uma sequência ordenada de cores que aumentam de intensidade conforme a sequência de valores apresentados nas classes estabelecidas (Archela G Théry, 2008).

2 Para os setores censitários que não tiveram as informações do entorno divulgadas, pelos motivos expostos, utilizou-se um método de interpolação determinístico do tipo IDW (inverso da distância ponderada) a fim de determinar os valores do ICE para os setores omissos. Esse método é mais indicado quando a área de estudo é coberta por um grande número de pontos igualmente espaçados (Mitas G Mitasova, 2005) e consiste na combinação linear do inverso da distância de pontos vizinhos conhecidos para determinar o valor de um ponto sem informação. Neste caso, o centroide de cada setor censitário foi extraído, o valor do ICE interpolado e o resultado transferido apenas para os setores sem informação.

\section{Referências}

ARCHELA, R. S. G THÉRY, H. Orientação metodológica para construção e leitura de mapas temáticos. Confins, online, 3: 1-21, 2008. Disponível em: <www.uel.br/cce/geo/didatico/ omar/pesquisa_geografia_fisica/Construcao_LeituradeMapas.pdf>. Acesso em: jun. 2017.

BESAG, J. Spatial interaction and the statistical analysis of lattice systems (with discussion). Journal of the Royal Statistical Society Series B, 36: 92-236, 1974.

CAMPOS, M. B. G ESTANISLAU, B. R. Demografia dos povos indígenas: os censos demográficos como ponto de vista. Revista Brasileira de Estudos de População-Rebep, 33(2): 441-449, 2016.

COMISSIÓN ECONÓMICA PARA AMÉRICA LATINA Y EL CARIBE (CEPAL). Los Pueblos Indígenas en América Latina: avances en el último decenio y retos pendientes para la garantía de sus derechos. Santiago, Chile: Centro Latino Americano de Demografia, 2014.

CUNHA, M. C. Índios no Brasil: história, direitos e cidadania. Rio de Janeiro: Claroenigma, 2012.

ESTANISLAU, B. R. A Eterna Volta: migração indígena e Pankararu no Brasil, 2014. Dissertação de Mestrado, Campinas: Instituto de Filosofia e Ciências Humanas, Universidade Estadual de Campinas.

HORTA, C. Indígenas em Canarana: notas citadinas sobre a criatividade parque-xinguana. Revista de Antropologia, 60(1): 216-241, 2017.

INSTITUTO BRASILEIRO DE GEOGRAFIA E ESTATÍSTICA (IBGE). Base de informações do Censo Demográfico 2010: resultados do universo por setor censitário. Rio de Janeiro: 
IBGE 2011. Disponível em: <ftp://ftp.ibge.gov.br/Censos/Censo_Demografico_2010/ Resultados_do_Universo/Agregados_por_Setores_Censitarios/>. Acesso em: jun. 2017.

INSTITUTO BRASILEIRO DE GEOGRAFIA E ESTATÍSTICA (IBGE). Características Gerais dos Indígenas: resultados do universo. Rio de Janeiro: IBGE, 2012.

LIGEIRO, R. et al. Defining quantitative stream disturbance gradients and the additive role of habitat variation to explain macroinvertebrate taxa richness. Ecological Indicators, 25: 45-57, 2013.

MITAS, L. G MITASOVA, H. Spatial interpolation. In: LONGLEY, P. et al. (Eds.). Geographical Information Systems: principles, techniques, management and applications. Hoboken: John Wiley G Sons, 2005.

NUNES, E. Aldeias urbanas ou cidades indígenas? Reflexões sobre índios e cidades. Espaço Ameríndio, 4(1): 9, 2010.

OLIVEIRA, J. P. O Nascimento do Brasil e Outros Ensaios: pacificação, regime tutelar e formação de alteridades. Rio de Janeiro: Contracapa, 2016.

OLIVEIRA, R. C. Urbanização e Tribalismo: a integração dos índios Terena numa sociedade de classes. Rio de Janeiro: Zahar Editores, 1968.

PAGLiARO, H.; AZEVEDO, M. M. G SANTOS, R. V. (Orgs.). Demografia dos Povos Indígenas no Brasil. Rio de Janeiro: Editora Fiocruz, Abep, 2005.

UNITED NATIONS (UN). State of the World's Indigenous Peoples. New York: UN, 2009. 


\section{Declaração de Idade em Indígenas e Não Indígenas no Censo Demográfico de 2010}

Barbara Coelho Barbosa da Cunha

Thatiana Fávaro

Luciene Guimarães de Souza

Ludimila Raupp

Geraldo Marcelo Cunha

Ricardo Ventura Santos

Como é amplamente reconhecido, indicadores demográficos, socioeconômicos e epidemiológicos são constantemente utilizados na caracterização das condições de vida de diferentes segmentos da população (Warren G Kennedy, 2008). Nesse contexto, os censos demográficos de abrangência nacional, cujas finalidades incluem contar e identificar as características dos habitantes e domicílios, têm extrema importância, uma vez que seus dados são utilizados no cômputo de tais indicadores (IBGE, 2010a, 2005; Jannuzzi, 2005; Médici, 1990). Estes instrumentos censitários constituem uma das principais fontes de dados sobre a situação de vida da população com representatividade nacional, e suas informações contribuem para a definição e direcionamento de políticas públicas (IBGE, 2010a, 2005).

No Brasil, a partir do Censo Demográfico 1991, ocorreu uma ampliação na captação das características de cor ou raça da população com a inclusão da opção "indígena" nas quatro alternativas então utilizadas (branca, preta, amarela e parda) (IBGE, 2012a). Em decorrência dessa inclusão, os censos passaram a ser importantes fontes de informações mais detalhadas sobre a população indígena, o que se fez refletir na produção de análises sobre o tema (Santos et al., 2019, 2015; Pereira, Filho G Sá, 2012; Azevedo, 2011; Marinho, Santos G Pereira, 2011; Santos G Teixeira, 2011; Borges et al., 2010; Pereira G Azevedo, 2004). Em 2010, a população brasileira era composta por cerca de 190 milhões de indivíduos, entre os quais 817.900 foram classificados como indígenas $(0,4 \%$ do total da população do país), distribuídos em 4.394 dos 5.565 municípios (IBGE, 2012a; Azevedo, 2011).

Uma vez que os censos demográficos estão voltados para captar as características da população em geral, um mesmo conjunto de perguntas e padrões de medidas é aplicado aos vários segmentos populacionais (Pereira, Filho G Sá, 2012; Jannuzzi, 2005). Por essa razão, no caso de povos culturalmente diferenciados, como os indígenas, a captação de certas classes de dados pode apresentar dificuldades particulares, não somente por questões linguísticas, mas também pelo uso de categorias que não se aplicam diretamente a contextos socioculturais específicos (Pagliaro, Azevedo G Santos, 2005). Outro ponto relevante diz respeito a quem responde aos questionários censitários, quer seja o próprio indivíduo, outro 
morador ou um não morador do domicílio. Em estudo com base nos dados do Censo 2010 para as regiões Norte e Nordeste, Santos e colaboradores (2015) observaram padrões diferenciados de respostas acerca de parturição em mulheres indígenas e não indígenas, a depender de quem forneceu as informações ao recenseador.

No campo da demografia e da saúde, a idade é uma importante variável de investigação, sendo largamente utilizada na construção de indicadores epidemiológicos e demográficos (Horta, 2012; Paes G Albuquerque, 1999). A definição utilizada, na maioria dos censos demográficos e sistemas de registros vitais do mundo, é a idade em anos completos por ocasião do último aniversário (ONU, 1955). No Brasil, essa variável é investigada desde o primeiro recenseamento nacional, realizado em 1872. A partir do Censo Demográfico 1940, passou-se a utilizar duas opções de respostas: data de nascimento, quando conhecida, ou idade presumida ou declarada (Horta, 2012; IBGE, 2012b; Oliveira, 2003; Gonçalves, 1995).

Nas sociedades humanas, a marcação do tempo tem uma dimensão fortemente cultural, de modo que seu significado e contagem apresentam características particulares, o que pode se refletir em distintas maneiras de definição de idade (Pagliaro, Mendonça G Baruzzi, 2009; Borges, 2004). Por essa razão, no caso de estudos em demografia antropológica com foco em populações indígenas, por vezes têm sido empregadas formas alternativas de obter informações sobre idade, como, por exemplo, calendários de eventos baseados em momentos marcantes da história recente da população e/ou análises de categorias que guardam proximidade com a dimensão etária (Coimbra et al., 2002; Flowers, 1994; Early G Peters, 1990; Werner, 1983; Howell, 1979).

Diante das particularidades potencialmente associadas à captação da idade em populações socioculturalmente diferenciadas, este capítulo tem como objetivo examinar o padrão de resposta da variável "forma de declaração de idade" no Censo Demográfico 2010, comparando indígenas e não indígenas. A exemplo de outras investigações recentes que abordaram variáveis demográficas para a população indígena no Brasil por meio da análise de dados censitários (Santiago G Verona, 2014), este estudo se baseia em uma amostra de indivíduos residentes em um conjunto de municípios com maior concentração de indígenas, opção que se justifica pela necessidade de maior comparabilidade de indígenas e não indígenas em âmbitos locais e regionais.

\section{Fontes dos dados, variáveis e análises}

No Brasil, os censos demográficos são realizados pelo Instituto Brasileiro de Geografia e Estatística (IBGE) e em geral acontecem com periodicidade decenal. Nos recenseamentos mais recentes, os dados foram obtidos por meio de dois tipos 
de questionários: um aplicado ao universo da população (questionário básico) e outro voltado para uma amostra (questionário da amostra). O segundo inclui, além de todas as perguntas presentes no questionário básico, o levantamento de dados acerca de fecundidade, migração, trabalho, mortalidade, dentre outros (IBGE, 2012c).

Este estudo foi realizado com base nos microdados oriundos do questionário da amostra do Censo Demográfico 2010. Foram incluídos os indivíduos com mais de 10 anos de idade, residentes em municípios com no mínimo 5\% de indígenas na população. Foram excluídas informações categorizadas como "ignorado" nos quesitos "cor ou raça" e "tipo de informante". Os menores de 10 anos não foram incluídos, pois, segundo a metodologia censitária, não são diretamente entrevistados, e uma das variáveis centrais de análise no presente estudo é "informante", ou seja, quem respondeu ao entrevistador (IBGE, 2010a). Decidiu-se pela proporção e não pela frequência absoluta na seleção dos municípios, pois a segunda opção envolveria um grande número de capitais e centros urbanos, várias dos quais com uma população indígena rarefeita. A seleção com base no critério de proporção permitiu a inclusão não somente de municípios com maior presença indígena, como também de parte expressiva daqueles com terras indígenas (TIs).

A variável de desfecho investigada foi "forma de declaração de idade", tendo como respostas: mês e o ano de nascimento ou idade declarada. No primeiro caso, a idade foi calculada pela subtração da data informada pela data de referência do Censo (31 de julho de 2010) (IBGE, 2011). Já a idade declarada foi aquela informada em anos completos ou meses, registrada, segundo IBGE (2010b), "apenas quando esgotados todos os esforços para obtenção da data de nascimento".

As variáveis independentes analisadas, com suas respectivas categorias, foram as seguintes: 1) segmento populacional (indígena ou não indígena, esta última categoria englobando os indivíduos classificados como brancos, pretos, pardos e amarelos); 2) tipo de informante - indivíduo que respondeu às perguntas referentes a cada morador (próprio morador, outro morador ou não morador); 3) macrorregião (Norte, Nordeste, Sudeste/Sul ou Centro-Oeste); 4) situação de domicílio (urbano ou rural); 5) sexo (masculino ou feminino); 6) faixa etária (nos seguintes intervalos: 10 a 29, 30 a 49 e igual ou maior a 50 anos); 7) saber ler e escrever, definido como escrever um bilhete simples no idioma que conhece (sim ou não); 8) rendimento domiciliar per capita em número de salários mínimos em julho de 2010 (nos seguintes intervalos: sem rendimento; até 0,25; entre 0,25 e 0,5; entre 0,5 e 1; e maior ( $\geq$ ) ou igual que um salário mínimo - SM). Devido ao número reduzido de indígenas em área urbana, os residentes no Sudeste e Sul foram agrupados em uma única categoria (Sudeste/Sul).

Frequências absolutas e relativas, estas últimas com o intervalo de confiança de 95\% (IC95\%) com o intuito de comparar os resultados, foram realizadas entre as categorias de segmento populacional, segundo as características sociodemográficas e econômicas. 
A associação da forma de declaração de idade com as covariáveis foi avaliada por meio de modelos de regressão logística gerados para cada categoria de tipo de informante, macrorregião e situação de domicílio. Os modelos foram primeiramente ajustados para cada uma das covariáveis, selecionando-se aquelas estatisticamente significativas ao nível de 25\%. Após a inclusão simultânea de todos os efeitos principais, o grau de associação e a significância estatística de cada uma das variáveis independentes em relação à forma de declaração de idade foram analisados por meio da estimativa da razão de chance (RC) ajustada (por sexo, faixa etária, ler e escrever e renda). Para essa análise, a fim de comparar o resultado entre as covariáveis e as categorias de segmento populacional, foi considerada a significância de 95\% (IC95\%). A RC informa se a chance, nesse caso, do indígena de informar a idade através da data de nascimento é maior ou menor em comparação ao não indígena. As análises foram conduzidas levando-se em consideração o desenho amostral probabilístico utilizado no Censo Demográfico 2010 (IBGE, 2012c).

\section{Características sociodemográficas, econômicas e fatores associados à forma de declaração de idade}

O estudo envolveu 167 municípios, assim distribuídos: 58 no Norte; 35 no Nordeste; 37 no Sudeste/Sul; e 37 no Centro-Oeste. Desses, somente dez não tinham, à época, TI (Funai, 2011). A população total investigada foi de 2.013 .981 indivíduos, dos quais 310.855 eram indígenas (15,4\%), constituindo 38,0\% da população indígena do país (51,5\% dos indígenas residentes em área rural - 53,9\% no Norte, 49,1\% no Nordeste, 44,4\% no Sudeste/Sul e 52,2\% no Centro-Oeste - e $16,5 \%$ em área urbana - 39,1\% no Norte, 20,0\% no Nordeste, 1,3\% no Sudeste Sul e $15,2 \%$ no Centro-Oeste). A macrorregião Norte concentrou a maior frequência populacional (39,0\%), o maior número de municípios e também a maior quantidade de municípios cujas populações eram constituídas por 50,0\% ou mais de indígenas.

$\mathrm{Na}$ amostra de municípios investigados, a maioria dos indígenas vivia em área rural (83,3\%), tinha entre 10 e 29 anos (59,2\%), residia em domicílios que recebiam até 0,25 SM per capita (63,6\%) e sabia ler e escrever $(70,1 \%)$ (Tabela 1). Quanto aos não indígenas, cerca de 50,0\% tinham entre 10 e 29 anos, mais de 80,0\% sabiam ler e escrever e 30,0\% recebiam até 0,25 SM per capita. Os não indígenas se mostraram mais concentrados em área urbana, principalmente nas regiões Norte e Nordeste. A despeito dessas diferenças, indígenas e não indígenas relataram predominantemente a data de nascimento (93,3\% e $94,7 \%)$, sendo a diferença estatisticamente significante (Tabela 1). 
Tabela 1 - Distribuição percentual (\%; IC95\%) dos indivíduos segundo segmento populacional e de acordo com as covariáveis investigadas. Municípios selecionados. Brasil - 2010

\begin{tabular}{|c|c|c|}
\hline \multirow[b]{2}{*}{ Covariáveis } & \multicolumn{2}{|c|}{ Segmento populacional } \\
\hline & $\begin{array}{c}\text { Indígena } \\
(\mathrm{N}=310.855)\end{array}$ & $\begin{array}{c}\text { Não indígena } \\
(\mathrm{N}=1.703 .126)\end{array}$ \\
\hline \multicolumn{3}{|l|}{ SEXo } \\
\hline Feminino & $51,0(50,6-51,4)$ & $51,4(51,2-51,5)$ \\
\hline Masculino & $49,0(48,6-49,4)$ & $48,6(48,5-48,8)$ \\
\hline \multicolumn{3}{|l|}{ FAIXA ETÁRIA (ANOS) } \\
\hline 10 a 29 & $59,2(58,8-59,7)$ & $48,7(48,5-48,9)$ \\
\hline 30 a 49 & $25,9(25,5-26,3)$ & $30,8(30,6-31,0)$ \\
\hline$\geq 50$ & $14,8(14,4-15,3)$ & $20,5(20,3-20,7)$ \\
\hline \multicolumn{3}{|l|}{ LER E ESCREVER } \\
\hline Sim & $70,1(69,4-70,8)$ & $83,5(83,3-83,7)$ \\
\hline Não & $29,9(29,2-30,6)$ & $16,5(16,3-16,7)$ \\
\hline \multicolumn{3}{|l|}{ RENDA (SM) } \\
\hline Sem rendimento & $18,5(17,6-19,4)$ & $6,3 \quad(6,1-6,6)$ \\
\hline até 0,25 & $45,1(43,9-46,2)$ & $24,2(23,8-24,6)$ \\
\hline 0,25 a 0,5 & $21,6(20,8-22,6)$ & $24,3(23,9-24,6)$ \\
\hline 0,5 a 1 & $11,2(10,6-11,9)$ & $25,0(24,6-25,3)$ \\
\hline$\geq 1$ & $3,6 \quad(3,3-4,0)$ & $20,2(19,9-20,5)$ \\
\hline \multicolumn{3}{|c|}{ FORMA DE DECLARAÇÃO DE IDADE } \\
\hline Data de nascimento & $93,3(92,8-93,8)$ & $94,7(94,6-94,9)$ \\
\hline Idade declarada & $6,7 \quad(6,2-7,2)$ & $5,3 \quad(5,1-5,4)$ \\
\hline \multicolumn{3}{|l|}{ MACRORREGIÃO } \\
\hline Norte & $50,1(49,1-51,2)$ & $36,8(36,5-37,1)$ \\
\hline Nordeste & $23,0(22,2-23,8)$ & $31,2(31,0-31,4)$ \\
\hline Sudeste/Sul & $9,0 \quad(8,6-9,4)$ & $9,6 \quad(9,5-9,7)$ \\
\hline Centro-Oeste & $17,8(17,0-18,7)$ & $22,4(22,3-22,6)$ \\
\hline \multicolumn{3}{|l|}{ SITUAÇÃO DE DOMICÍLIO } \\
\hline Urbano & $16,7(16,0-17,5)$ & $63,2(62,8-63,6)$ \\
\hline Rural & $83,3(82,5-84,0)$ & $36,8(36,4-37,2)$ \\
\hline \multicolumn{3}{|l|}{ INFORMANTE } \\
\hline A própria pessoa & $40,0(43,4-43,8)$ & $44,3(44,0-44,5)$ \\
\hline Outro morador & $48,2(51,9-52,4)$ & $52,9(52,7-53,2)$ \\
\hline Não morador & $11,7 \quad(4,0-4,4)$ & $2,8 \quad(2,7-2,9)$ \\
\hline
\end{tabular}

Fonte: IBGE, microdados do Censo Demográfico 2010. 
Em relação à pessoa que proveu a resposta ao recenseador, chama a atenção o maior percentual da categoria "não morador" entre os indígenas $(11,7 \%)$, cerca de cinco vezes superior ao observado para não indígenas $(2,8 \%)$ (Tabela 1$)$. Independentemente da macrorregião, da situação do domicílio e do segmento populacional, o informante mais frequente foi "outro morador" (Tabela 2). Para indígenas da área rural do Norte $(15,7 \%)$ e do Centro-Oeste (18\%), as frequências de resposta por "não morador" foram até seis vezes maiores que aquelas para não indígenas.

Tabela 2 - Distribuição percentual (\%; IC95\%) dos indivíduos segundo tipo de informante e segmento populacional, de acordo com a situação de domicílio e a macrorregião. Municípios selecionados. Brasil - 2010

\begin{tabular}{|c|c|c|c|c|c|c|c|}
\hline \multirow{2}{*}{$\begin{array}{c}\text { Situação } \\
\text { do } \\
\text { domicílio }\end{array}$} & \multirow[b]{2}{*}{ Macrorregião } & \multicolumn{2}{|c|}{ Própria pessoa } & \multicolumn{2}{|c|}{ Outro morador } & \multicolumn{2}{|c|}{ Não morador } \\
\hline & & Indígena & $\begin{array}{c}\text { Não } \\
\text { indígena }\end{array}$ & Indígena & $\begin{array}{c}\text { Não } \\
\text { indígena }\end{array}$ & Indígena & $\begin{array}{c}\text { Não } \\
\text { indígena }\end{array}$ \\
\hline \multirow{4}{*}{ Urbano } & Norte & $38,3(36,0-40,6)$ & $40,0(39,5-40,5)$ & $59,2(56,8-61,6)$ & $57,5(57,0-58,0)$ & $2,5 \quad(1,7-3,8)$ & $2,6(2,3-2,9)$ \\
\hline & Nordeste & $42,5(40,7-44,5)$ & $43,3(42,8-43,8)$ & $55,3(53,3-57,2)$ & $54,1(53,6-54,7)$ & $2,2 \quad(1,4-3,2)$ & $2,6(2,3-2,9)$ \\
\hline & Sudeste/Sul & $45,5(37,1-54,1)$ & $47,8(47,2-48,5)$ & $52,6(43,9-61,1)$ & $49,6(49,0$ - 50,2) & $2,0 \quad(0,6-6,1)$ & $2,6(2,3-2,9)$ \\
\hline & Centro-Oeste & $43,9(39,9-47,9)$ & $43,3(42,8-43,7)$ & $53,7(49,6-57,9)$ & $57,3(53,3-54,3)$ & $2,4 \quad(1,3-4,3)$ & $3,0(2,7-3,3)$ \\
\hline \multirow{4}{*}{ Rural } & Norte & $40,4(39,1-41,6)$ & $48,2(47,2-49,1)$ & $44,0(42,6-45,3)$ & $48,5(47,5-49,4)$ & $15,7(14,3-17,1)$ & $3,4(3,0-3,8)$ \\
\hline & Nordeste & $43,9(42,5-45,3)$ & $45,1(44,4-45,7)$ & $49,2(47,6-50,7)$ & $51,9(51,2-52,5)$ & $6,9 \quad(5,7-8,4)$ & $3,1(2,7-3,5)$ \\
\hline & Sudeste/Sul & $37,7(36,3-39,1)$ & $49,6(48,9-50,2)$ & $54,7(53,1-56,3)$ & $48,2(47,5-48,9)$ & $7,6 \quad(6,3-9,1)$ & $2,2(1,9-2,6)$ \\
\hline & Centro-Oeste & $35,9(34,8-37,8)$ & $49,3(48,4-47,8)$ & $46,1(43,8-48,4)$ & $47,4(46,6-48,3)$ & $18,0(15,2-21,2)$ & $3,2(2,8-3,8)$ \\
\hline
\end{tabular}

Fonte: IBGE, microdados do Censo Demográfico 2010.

Na área urbana, de maneira geral, indígenas declararam proporcionalmente mais a idade que os não indígenas (Tabela 3). Em todas as faixas etárias, as proporções de indígenas que não informaram a data de nascimento foram maiores comparadas às observadas em não indígenas, com exceção dos moradores do Nordeste. Indígenas da área urbana que ganhavam mais de um SM, ao contrário das outras categorias, e com exceção do Nordeste, responderam com menor frequência a idade através da data de nascimento. Além disso, somente no Nordeste, indígenas do sexo feminino apresentaram percentuais maiores de idade declarada do que indígenas do sexo masculino. No Centro-Oeste, diferentemente das outras macrorregiões, a idade declarada foi menos frequente entre os indígenas que não sabiam ler e escrever, o que indica, inesperadamente que, nesse caso, a data de nascimento foi mais referida. Quando questionário foi respondido por outro morador, com exceção do Nordeste, as proporções de idade declarada em indígenas foram maiores que as observadas em não indígenas. 
Tabela 3 - Distribuição percentual (\%; IC95\%) dos indivíduos na categoria idade declarada, no quesito declaração de idade, de acordo com as covariáveis investigadas e segundo segmento populacional e macrorregião. Área urbana, municípios selecionados. Brasil - 2010

\begin{tabular}{|c|c|c|c|c|c|c|c|c|}
\hline \multirow{2}{*}{ Variáveis } & \multicolumn{2}{|c|}{ Norte } & \multicolumn{2}{|c|}{ Nordeste } & \multicolumn{2}{|c|}{ Sudeste/Sul } & \multicolumn{2}{|c|}{ Centro-Oeste } \\
\hline & Indígena & Não indígena & Indígena & Não indígena & Indígena & Não indígena & Indígena & Não indígena \\
\hline \multicolumn{9}{|l|}{ SEXo } \\
\hline Feminino & $0,3(7,1-12,0)$ & $5,1 \quad(4,7-5,5)$ & $6,4 \quad(4,7-8,6)$ & $7,7 \quad(7,1-8,3)$ & $11,6(4,7-26,0)$ & $2,7 \quad(2,1-3,3)$ & $7,0 \quad(4,4-10,9)$ & $(5,8-6,3)$ \\
\hline Masculino & $6,8 \quad(5,1-8,9)$ & $4,4 \quad(4,0-4,8)$ & $5,5 \quad(4,0-7,5)$ & $6,2 \quad(5,7-6,7)$ & $9,0(2,6-27,2)$ & $2,3 \quad(1,9-2,7)$ & $8,9 \quad(5,2-14,8)$ & $(5,0-5,9)$ \\
\hline \multicolumn{9}{|l|}{ FAIXA ETÁRIA (ANOS) } \\
\hline 10 a 29 & $8,3(6,1-11,1)$ & $4,6 \quad(4,1-5,0)$ & $5,7 \quad(4,1-7,8)$ & $6,8 \quad(6,2-7,4)$ & $10,6(3,7-27,0)$ & $2,5 \quad(2,0-3,1)$ & $9,6 \quad(6,2-14,6)$ & $(5,9-7,0)$ \\
\hline 30 a 49 & $7,1 \quad(5,2-9,7)$ & $4,9 \quad(4,5-5,4)$ & $5,5 \quad(3,8-7,8)$ & $7,0 \quad(6,4-7,6)$ & $9,5(3,7-22,2)$ & $2,6 \quad(1,9-3,0)$ & $6,6 \quad(3,5-12,3)$ & $5,8 \quad(5,3-6,3)$ \\
\hline$\geq 50$ & $8,6(5,9-12,4)$ & $5,0 \quad(4,4-5,6)$ & $7,2(4,6-11,1)$ & $7,1 \quad(6,4-7,8)$ & $10,4(3,3-28,2)$ & $2,5 \quad(2,1-3,1)$ & $5,8 \quad(2,8-11,6)$ & $(5,4-6,6)$ \\
\hline \multicolumn{9}{|l|}{ LER E ESCREVER } \\
\hline Sim & $8,0(6,2-10,3)$ & $4,7 \quad(4,3-5,1)$ & $5,2 \quad(3,9-7,0)$ & $6,2 \quad(5,8-6,7)$ & $10,2(3,3-27,2)$ & $2,2 \quad(1,8-2,6)$ & $8,2 \quad(5,3-12,5)$ & $(5,3-6,2)$ \\
\hline Não & $8,0(4,9-13,0)$ & $5,3 \quad(4,5-6,3)$ & $9,0(6,2-13,0)$ & $9,7 \quad(8,8-10,7)$ & $10,9(4,5-24,0)$ & $5,3 \quad(4,0-6,9)$ & $6,7 \quad(3,3-13,1)$ & $10,6 \quad(9,3-12,1)$ \\
\hline \multicolumn{9}{|l|}{ RENDA (SM) } \\
\hline Sem rendimento & $9,5(3,6-23,1)$ & $7,6 \quad(5,6-10,1)$ & $5,2(2,2-11,8)$ & $10,6 \quad(8,2-13,6)$ & ${ }^{*}$ & $5,7(2,9-10,9)$ & $27,6 \quad(6,3-68,3)$ & $20,8(17,8-25,3)$ \\
\hline até 0,25 & $8,4(5,3-13,0)$ & $4,9 \quad(4,1-5,9)$ & $6,9(4,4-10,5)$ & $7,8 \quad(6,8-9,0)$ & $1,0 \quad(0,1-6,5)$ & $3,7 \quad(2,3-6,0)$ & $6,2 \quad(2,1-16,9)$ & $10,6 \quad(8,3-13,4)$ \\
\hline 0,25 a 0,5 & $6,0 \quad(3,6-9,8)$ & $4,4 \quad(3,8-5,1)$ & $7,6(4,6-12,2)$ & $7,3 \quad(6,5-8,2)$ & $18,4(3,4-54,1)$ & $3,3 \quad(2,0-5,5)$ & $6,4 \quad(3,4-11,7)$ & $6,9 \quad(5,9-8,0)$ \\
\hline 0,5 a 1 & $8,2(5,3-12,7)$ & $5,3 \quad(4,6-6,1)$ & $4,5 \quad(2,8-7,1)$ & $6,8 \quad(6,0-7,7)$ & $12,2(2,0-49,0)$ & $3,3 \quad(2,5-4,1)$ & $5,8 \quad(2,1-15,3)$ & $5,5 \quad(4,8-6,2)$ \\
\hline$\geq 1$ & $10,3(4,8-20,8)$ & $3,7 \quad(3,0-4,4)$ & $1,9 \quad(0,8-4,3)$ & $4,1 \quad(3,3-5,0)$ & $13,8(4,7-34,1)$ & $1,2 \quad(0,8-1,6)$ & $11,3 \quad(4,5-25,5)$ & $(3,5-4,5)$ \\
\hline \multicolumn{9}{|l|}{ INFORMANTE } \\
\hline A própria pessoa & $2,8 \quad(1,9-4,1)$ & $2,2 \quad(1,9-2,6)$ & $2,4 \quad(1,4-3,9)$ & $3,1 \quad(2,8-3,5)$ & $2,1 \quad(0,7-6,1)$ & $1,1 \quad(0,8-1,4)$ & $(0,9-4,5)$ & $(1,9-2,5)$ \\
\hline Outro morador & $10,9(8,3-14,2)$ & $6,1 \quad(5,6-6,6)$ & $7,9(6,0-10,5)$ & $9,5 \quad(8,6-10,2)$ & $17,7(6,2-41,2)$ & $3,4 \quad(2,7-4,1)$ & $11,7 \quad(7,5-17,8)$ & $(7,7-8,9)$ \\
\hline Não morador & $18,7(6,2-44,6)$ & $13,7(10,8-17,2)$ & $23,8(9,7-47,8)$ & $16,7(13,5-20,5)$ & * & $10,7(7,4-15,1)$ & $33,5(14,6-59,8)$ & $23,4(19,5-27,8)$ \\
\hline Total & $8,0(6,2-10,2)$ & $4,7 \quad(4,4-5,1)$ & $5,9 \quad(4,5-7,7)$ & $6,9 \quad(6,5-7,4)$ & $10,3(3,9-24,7)$ & $2,5 \quad(2,1-2,9)$ & $8,0 \quad(5,2-12,1)$ & $6,1 \quad(5,7-6,5)$ \\
\hline
\end{tabular}

* $100 \%$ das populações informaram a data de nascimento.

Fonte: IBGE, microdados do Censo Demográfico 2010. 
Assim como observado na área urbana, indígenas da área rural também declararam proporcionalmente mais a idade que não indígenas, e as maiores diferenças foram observadas no Sudeste/Sul (Tabela 4). Indígenas e não indígenas da macrorregião Nordeste apresentaram as maiores frequências de idade declarada quando comparadas com o observado as demais macrorregiões. Cabe destacar que no Sudeste/Sul as proporções de idade declarada para os indígenas superaram em até sete vezes os valores observados entre não indígenas. Indígenas e não indígenas do sexo masculino apresentaram percentuais de idade declarada maiores do que indivíduos do sexo feminino. Moradores que não sabiam ler e escrever da macrorregião Nordeste, de ambos os segmentos populacionais, apresentaram os maiores percentuais de idade declarada, comparados aos moradores das demais regiões. Destacam-se os valores acima de 10\% de idade declarada para os não indígenas sem rendimento do Nordeste e para os indígenas com mais do que um SM do CentroOeste. Comparado aos não indígenas, para os indígenas cujos informantes foram "não moradores", foram encontradas menores proporções de idade declarada, com exceção do Sudeste/Sul, com destaque para as macrorregiões Norte e Centro-Oeste, onde "não moradores" informaram, para mais de 90\% dos indivíduos, a data de nascimento dos indígenas. 
Tabela 4 - Distribuição percentual (\%; IC95\%) dos indivíduos na categoria idade declarada, no quesito declaração de idade, de acordo com as covariáveis investigadas e segundo segmento populacional e macrorregião. Área rural, municípios selecionados. Brasil - 2010

\begin{tabular}{|c|c|c|c|c|c|c|c|c|}
\hline \multirow{2}{*}{ Variáveis } & \multicolumn{2}{|c|}{ Norte } & \multicolumn{2}{|c|}{ Nordeste } & \multicolumn{2}{|c|}{ Sudeste/Sul } & \multicolumn{2}{|c|}{ Centro-Oeste } \\
\hline & Indígena & Não indígena & Indígena & Não indígena & Indígena & Não indígena & Indígena & Não indígena \\
\hline \multicolumn{9}{|l|}{ SEXo } \\
\hline Feminino & $6,3(5,4-7,3)$ & $4,6(4,0-5,2)$ & $9,5(8,1-11,2)$ & $7,4(6,8-8,1)$ & $6,4(5,3-7,8)$ & $1,1(0,8-1,4)$ & $5,7(4,8-6,9)$ & $4,2(3,6-4,8)$ \\
\hline Masculino & $6,0(5,2-7,1)$ & $3,7(3,2-4,2)$ & $7,8(6,6-9,1)$ & $6,4(5,9-7,1)$ & $6,2(5,0-7,6)$ & $1,0(0,8-1,4)$ & $5,6(4,6-6,7)$ & $3,8(3,2-4,6)$ \\
\hline \multicolumn{9}{|l|}{ FAIXA ETÁRIA (ANOS) } \\
\hline 10 a 29 & $6,4(5,4-7,5)$ & $4,2(3,6-4,9)$ & $8,9(7,5-10,5)$ & $7,0(6,3-7,8)$ & $6,5(5,4-7,9)$ & $1,2(0,9-1,7)$ & $5,6(4,6-6,8)$ & $4,0(3,2-4,8)$ \\
\hline 30 a 49 & $5,8(4,8-6,9)$ & $3,8(3,3-4,4)$ & $8,6(7,1-10,3)$ & $6,7(6,0-7,4)$ & $5,4(4,3-6,9)$ & $1,0(0,8-1,4)$ & $5,9(4,6-7,5)$ & $4,3(3,6-5,2)$ \\
\hline$\geq 50$ & $6,2(5,0-7,7)$ & $5,0(4,2-6,0)$ & $8,1(6,2-10,5)$ & $7,1(6,3-7,9)$ & $6,9(5,1-9,2)$ & $0,9(0,6-12)$ & $5,5(4,1-7,5)$ & $3,6(2,7-4,7)$ \\
\hline \multicolumn{9}{|l|}{ LER E ESCREVER } \\
\hline Sim & $6,9(5,9-8,0)$ & $4,2(3,7-4,8)$ & $8,0(6,8-9,4)$ & $5,9(5,4-6,5)$ & $6,7(5,6-8,1)$ & $0,9(0,7-1,2)$ & $5,6(4,6-6,7)$ & $3,9(3,3-4,5)$ \\
\hline Não & $5,1(4,0-6,6)$ & $4,2(3,6-5,0)$ & $10,1(8,3-12,2)$ & $9,3(8,4-10,3)$ & $4,8(3,6-6,4)$ & $2,2(1,4-3,4)$ & $5,9(4,6-7,5)$ & $5,1(3,9-6,6)$ \\
\hline \multicolumn{9}{|l|}{ RENDA (SM) } \\
\hline Sem rendimento & $3,2(2,3-4,5)$ & $3,3(2,5-4,4)$ & $6,1(3,9-9,4)$ & $14,8(11,2-19,4)$ & $4,2(2,2-8,1)$ & $1,6(0,8-3,2)$ & $2,2(1,3-3,6)$ & $2,8(1,1-6,9)$ \\
\hline Até 0,25 & $7,4(6,0-9,1)$ & $4,0(3,3-4,9)$ & $9,7(7,9-11,9)$ & $6,1(5,7-7,8)$ & $7,4(5,7-9,4)$ & $1,7(1,1-2,6)$ & $5,2(3,9-6,8)$ & $3,9(2,9-5,2)$ \\
\hline 0,25 a 0,5 & $8,7(6,6-11,5)$ & $5,2(3,9-6,7)$ & $9,2(6,7-12,4)$ & $6,7(5,7-7,8)$ & $6,2(4,1-9,1)$ & $1,7(1,1-2,6)$ & $8,1(6,0-10,8)$ & $3,9(2,9-5,2)$ \\
\hline 0,5 a 1 & $5,8(2,7-11,7)$ & $4,0(2,8-5,7)$ & $7,1(4,9-10,3)$ & $6,3(5,4-7,4)$ & $4,8(3,1-7,4)$ & $1,0(0,6-1,5)$ & $6,7(4,2-10,6)$ & $4,2(3,3-5,3)$ \\
\hline$\geq 1$ & $5,7(2,7-11,5)$ & $5,0(3,5-7,0)$ & $3,0(1,3-6,2)$ & $7,0(5,2-9,3)$ & $2,6(0,7-8,4)$ & $0,6(0,3-1,0)$ & $11,8(6,1-21,4)$ & $3,6(2,8-4,8)$ \\
\hline \multicolumn{9}{|l|}{ INFORMANTE } \\
\hline A própria pessoa & $4,8(3,7-6,1)$ & $2,2(1,9-2,6)$ & $4,8(3,8-6,0)$ & $5,1(4,5-5,8)$ & $2,3(1,7-3,1)$ & $0,4(0,3-0,7)$ & $3,5(2,6-4,6)$ & $1,2(0,9-1,5)$ \\
\hline Outro morador & $6,8(5,8-8,1)$ & $5,6(4,9-6,5)$ & $11,4(9,8-13,3)$ & $7,5(6,8-8,2)$ & $7,6(6,1-9,4)$ & $1,2(0,9-1,6)$ & $6,8(5,5-8,4)$ & $5,6(4,7-6,6)$ \\
\hline Não morador & $8,0(5,8-11,0)$ & $12,2(9,2-16,0)$ & $13,8(8,4-21,9)$ & $24,5(19,1-30,9)$ & $17,3(11,7-24,8)$ & $10,8(6,2-18,1)$ & $6,9(4,7-10,1)$ & $24,2(18,4-31,0)$ \\
\hline Total & $6,2(5,3-7,2)$ & $4,2(3,7-4,7)$ & $8,7(7,5-10,1)$ & $6,9(6,4-7,5)$ & $6,3(5,2-7,6)$ & $1,1(0,8-1,3)$ & $5,6(4,8-6,7)$ & $4,0(3,5-4,6)$ \\
\hline
\end{tabular}

Fonte: IBGE, microdados do Censo Demográfico 2010. 
De forma consistente, os resultados das regressões logísticas evidenciaram diferenças nas chances de a resposta sobre a idade ser proveniente da data de nascimento entre indígenas e não indígenas nos distintos tipos de informante e situação de domicílio (Figura 1). Para área urbana, após o ajuste pelas covariáveis de interesse, constataram-se diferenças significativas nas regiões Norte e Sudeste/ Sul. Nessas áreas, quando o informante foi "outro morador", a chance de a data de nascimento ter sido relatada para indivíduos indígenas foi menor quando comparada aos não indígenas - RC=0,53 (IC95\%: 0,39-0,73); RC=0,18 (IC95\%: 0,05-0,64), respectivamente para o Norte e Sudeste/Sul.

$\mathrm{Na}$ área rural, quando os informantes foram a "própria pessoa", com exceção do Nordeste, e "outro morador", as chances de os indígenas terem informado a data de nascimento foram menores comparados aos não indígenas. Ao contrário do esperado a princípio, quando o informante foi um "não morador" nas regiões Nordeste e Centro-Oeste, as associações mudaram de sentido, ou seja, a chance de o indígena ter a data do nascimento informada foi maior em comparação aos não indígenas - RC=2,05 (IC95\%: 1,10-3,84), RC=2,34 (IC95\%: 1,23-4,45), respectivamente.

Figura 1 - Razões de chances ajustadas* (IC95\%) para a data de nascimento, como forma de declaração de idade, de acordo com o tipo de informante e segundo macrorregião, em área urbana (A) e rural (B). ${ }^{* *}$ Municípios selecionados. Brasil 2010

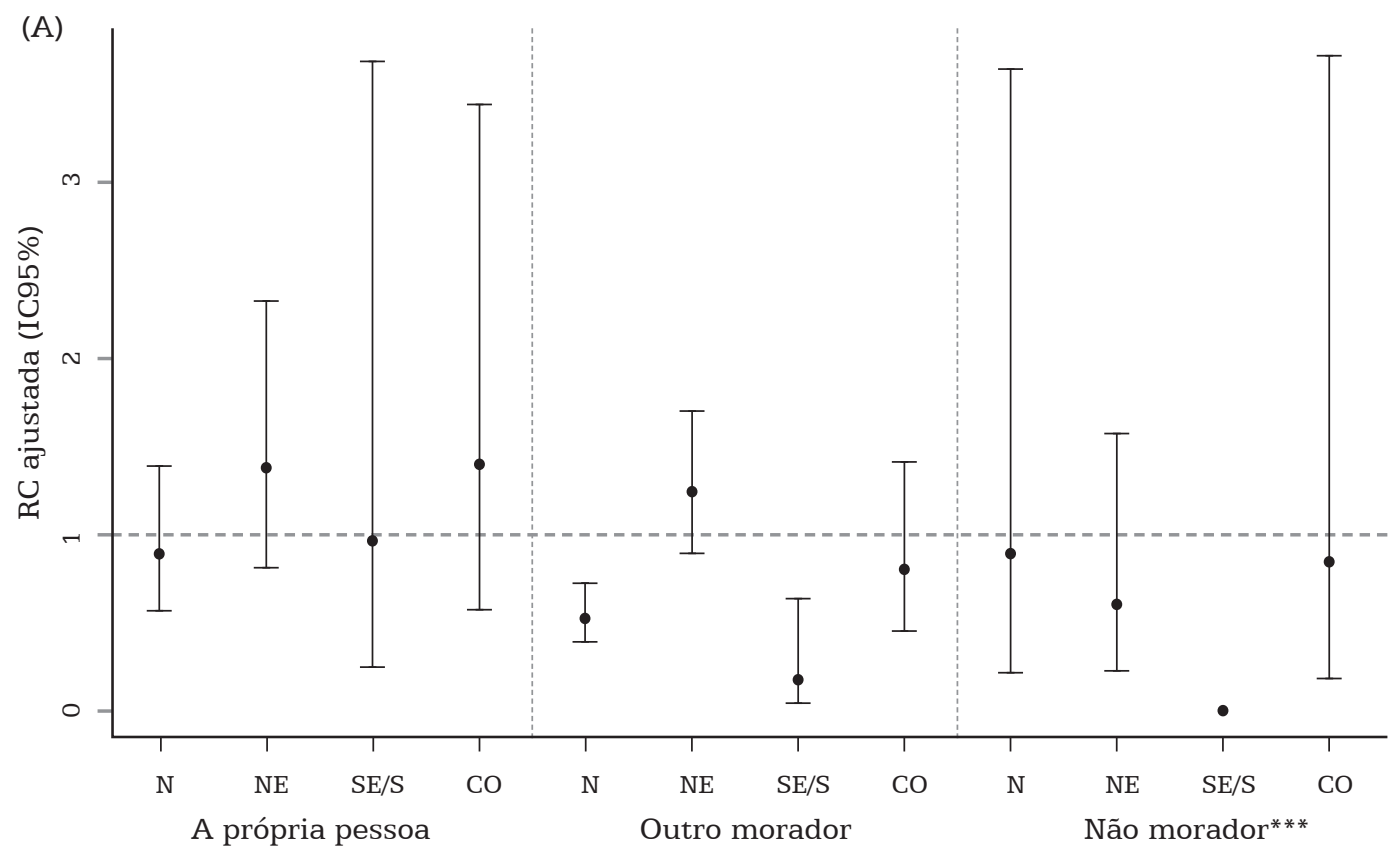


Figura 1 - Razões de chances ajustadas* (IC95\%) para a data de nascimento, como forma de declaração de idade, de acordo com o tipo de informante e segundo macrorregião, em área urbana (A) e rural (B). ${ }^{* *}$ Municípios selecionados. Brasil 2010 (cont.)

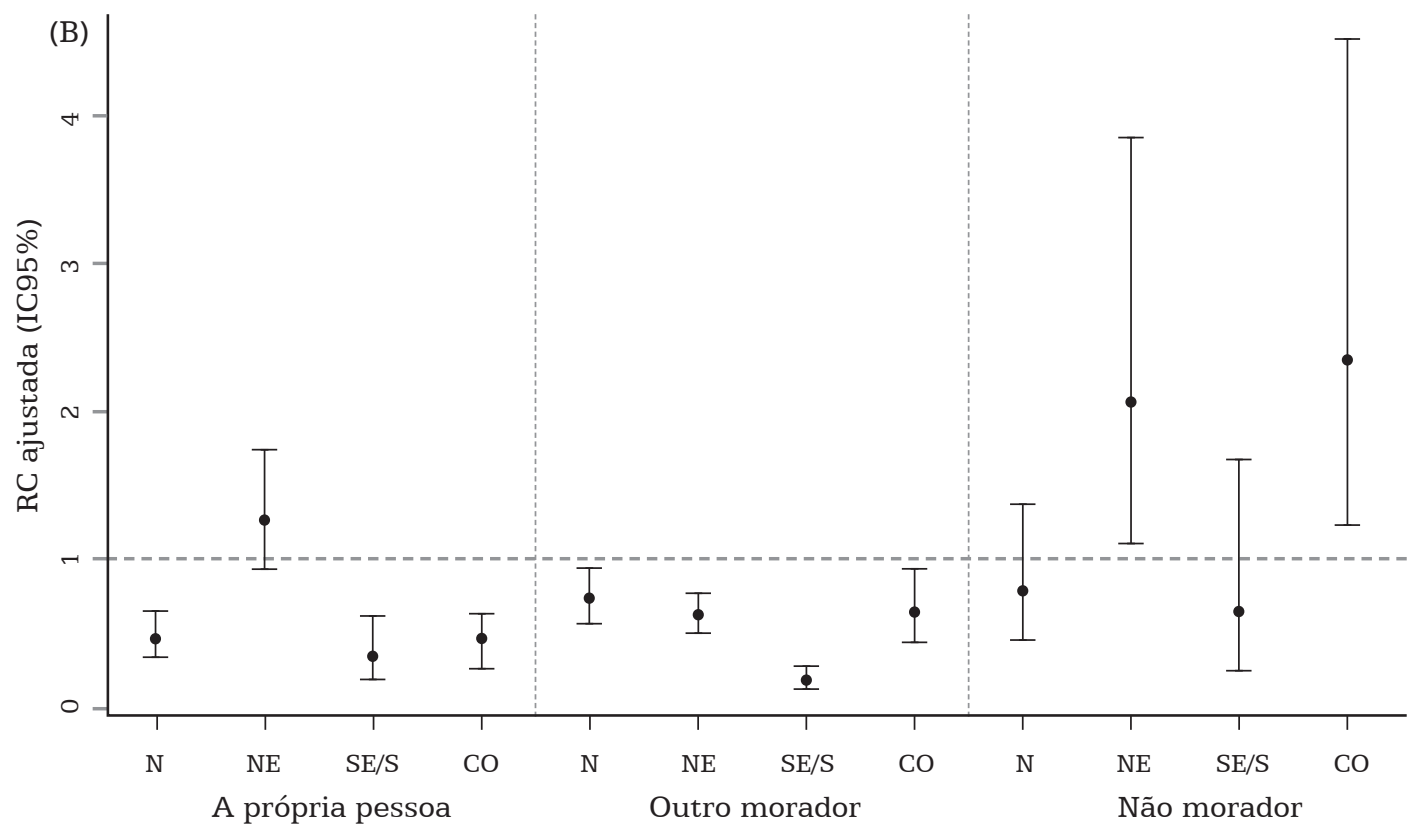

* As covariáveis utilizadas para o ajuste dos modelos, não apresentadas graficamente, foram: sexo, faixa etária, ler e escrever e renda.

** O segmento não indígena foi a categoria de referência $(1,00)$.

*** Não há resultado para SU/S na área urbana para o informante "não morador" (área urbana) devido ao número populacional reduzido.

OBS.: N - Norte, NE - Nordeste, SE/S - Sudeste/Sul, CO - Centro-Oeste.

Fonte: IBGE, microdados do Censo Demográfico 2010.

\section{Considerações finais}

Os resultados deste estudo evidenciam particularidades na população indígena em comparação à não indígena nas respostas da "forma de declaração de idade" e nas associações com as covariáveis analisadas. Houve predomínio da data de nascimento nos dois segmentos, com frequências acima de $90 \%$ em ambas. Não obstante, apesar da idade declarada ter se mostrado menos expressiva, a população indígena apresentou um percentual mais elevado. Ao analisar os dados do Censo Demográfico 2010, Pereira, Filho e Sá (2012) também observaram uma baixa fre- 
quência de idade declarada em indígenas em comparação com a data de nascimento, esta última também superior a 90\%.

A idade quando informada pela data de nascimento, ainda que seja potencialmente mais precisa que a declarada (Horta, Sawyer G Carvalho, 2006; Hobbs, 2004), no caso da população indígena no Brasil, deve ser analisada com cautela. Azevedo (2009) investigou quatro etnias do Alto Rio Negro a partir do Censo Indígena Autônomo do Rio Negro, conduzido pela Federação das Organizações Indígenas do Rio Negro. Foram excluídas do estudo as mulheres que não informaram a idade delas e a idade de seus filhos nascidos vivos, sobreviventes ou mortos, sem que tenha sido declarada a causa dessa exclusão. Souza e Santos (2001) mencionam que é comum que indígenas adultos obtenham certidão de nascimento muito tempo após seu nascimento, e por esse motivo a data de nascimento pode ser aproximada. Há outras dimensões, de ordem antropológica, que também devem ser consideradas. Nesse sentido, os marcadores de tempo são fortemente influenciados por aspectos socioculturais, de modo que, para muitas sociedades indígenas, a data de nascimento não tem a centralidade observada nas sociedades ocidentais (Pereira, Filho G Sá, 2012; Borges et al., 2010; Flowers, 1994; Werner, 1983).

Conforme esperado, e de maneira geral, para indígenas e não indígenas, quando a "própria pessoa" respondeu ao Censo, observou-se maior frequência de registro de data de nascimento, ao passo que "não moradores" tenderam a relatar mais idade declarada. Contudo, para indígenas das áreas rurais do Norte e do Centro-Oeste, o "não morador" informou a data de nascimento com uma frequência mais elevada. Destaca-se também que a análise da associação da forma de declaração de idade com as covariáveis consideradas neste estudo reforça a diferença na chance de os indígenas, em relação aos não indígenas, informarem a data de nascimento. Além disso, esse resultado reafirma a influência da situação de domicílio (área urbana e rural) e da pessoa que respondeu ao questionário.

Santana e colaborados (1997), por exemplo, constaram que a qualidade da informação se associa ao grau de aproximação do respondente com o investigado. Jardim, Barreto e Giatti (2010), por sua vez, encontraram viés na resposta proveniente de um segundo informante e concluíram ser mais adequado, em inquéritos, usar somente um entrevistado. Santos e colaboradores (2015), com base nos dados do Censo Demográfico 2010 para as regiões Norte e Nordeste, verificaram que a pessoa que responde tem uma influência importante nos níveis de parturição relatados. Especificamente, os autores mostraram que, nos casos em que os entrevistados eram "outro morador" e "não morador", houve uma tendência a subestimar a contagem de filhos, particularmente entre mulheres indígenas do Norte.

O manual do Censo Demográfico 2010 indica que deve ser preferencialmente entrevistado o responsável pelo domicílio e, na sua ausência, uma pessoa que tenha conhecimento suficiente sobre os demais moradores (IBGE, 2010b). 
Os resultados deste estudo evidenciaram a predominância proporcional de "outro morador" respondendo aos questionários, em ambas as populações. Tal situação é esperada, uma vez que o recenseador nem sempre encontra todos os moradores no domicílio no momento da coleta de dados e, nesses casos, quem deve responder ao questionário é o responsável pelo domicílio.

No entanto, em relação ao respondente, segundo Cavenaghi e Alves (2011), observações de campo e análises de relatórios dos recenseadores mostraram que as recomendações do manual não são necessariamente seguidas. Uma situação comumente observada para indígenas na área rural foi a elevada frequência de "não morador" no Norte e Centro-Oeste, menos pronunciada no Sudeste/Sul e no Nordeste, respondendo aos questionários. Com base apenas nos dados censitários, não é possível explicar as razões associadas ao fato de "outro morador" e "não morador" terem maior participação nas respostas no caso dos indígenas. Em particular, quanto ao "não morador", é possível que se refira aos profissionais de educação e de saúde que trabalham e residem nas comunidades indígenas e que, por conhecerem bem a população, tenham atuado como mediadores das entrevistas censitárias (Santos et al., 2015; Coimbra et al., 2013; Marinho, Santos G Pereira, 2011).

Com respeito a investigações sobre as populações indígenas, Howell (1979) e Pagliaro, Azevedo e Santos (2005) afirmam que a colaboração entre demógrafos e antropólogos pode ser importante para melhorar a qualidade dos dados demográficos, incluindo aqueles referentes à idade. Howell (1979), Werner (1983), Early e Peters (1990), Flowers (1994) e Coimbra e colaboradores (2002) descrevem diversas técnicas voltadas para a coleta de dados acerca de idade em populações indígenas. No âmbito dos censos nacionais, para fins da coleta de dados sobre povos culturalmente diferenciados, como os indígenas, por certo não é exequível a incorporação em larga escala de métodos particulares. Não obstante, no caso da realização de futuros levantamentos, mais circunscritos, seja por agências governamentais ou não, dirigidos especificamente para indígenas, seria importante explorar, na fase de planejamento e elaboração dos questionários, as potencialidades de procedimentos metodológicos previamente propostos por antropólogos e demógrafos que trabalham com comunidades indígenas (Coimbra et al., 2002; Flowers, 1994; Early G Peters, 1990; Werner, 1983).

De acordo com Pereira, Filho e Sá (2012), o aumento na frequência de resposta ao quesito sobre idade a partir da data de nascimento, assim como a melhora nos índices que medem a qualidade dessa informação (Myers, Whipple e Nações Unidas), referente aos indígenas, nos Censos Demográficos 1991, 2000 e 2010, podem estar relacionados ao tipo de instrumento de coleta e à estrutura da pergunta. Em 1991, os dados coletados foram anotados manualmente em questionários impressos e digitalizados posteriormente. Quando a informação sobre a data exata do nascimento era obtida, o entrevistador não perguntava a idade em anos 
completos. Em 2000, os questionários também foram respondidos em papel, porém foram escaneados. Além disso, tanto a informação da data de nascimento quanto a idade em anos foram averiguadas. Finalmente, em 2010, os dados foram digitalizados no momento da entrevista, com o uso de um personal digital assistant (PDA), e as opções de resposta quanto à idade foi similar à utilizada no Censo de 1991.

Podem ser mencionadas diversas implicações em potencial quanto aos resultados do presente estudo no âmbito das pesquisas sobre demografia da população indígena no Brasil. Ainda que este trabalho não tenha incluído crianças menores de 10 anos, um exemplo particularmente pertinente se refere aos índices de mortalidade infantil, pois seu cálculo depende da precisão da idade, cujos níveis se mostram substancialmente mais elevados na população indígena se comparados ao restante da população brasileira (Cardoso, Santos G Coimbra, 2005; IBGE, 2005). Com base nos dados do Sistema de Informação de Mortalidade (SIM), Caldas e colaboradores (2017) evidenciaram que a taxa de mortalidade infantil de indígenas no Brasil em 2009-2010 foi de 47,2 por mil, substancialmente mais elevada que nas demais categorias de cor ou raça (variando de 15,2 por mil em crianças de cor ou raça branca a 29,1 em crianças de cor ou raça preta). Em parte, essas diferenças, principalmente para indígenas e pretos, devem-se ao componente pós-neonatal, relacionado a óbitos ocorridos entre 28 e 364 dias de vida. Desse modo, em estudos sobre iniquidades em saúde envolvendo a população indígena, como é o caso da mortalidade infantil, é de particular importância o acesso a dados os mais fidedignos possíveis acerca de idade, de preferência baseados na data de nascimento. Como observado nesta investigação, as diferenças entre indígenas e não indígenas, no tocante às frequências de idade reportada, se mostraram mais evidentes nas áreas rurais, onde possivelmente também ocorrem as mais pronunciadas diferenças nos níveis de mortalidade infantil e de seus componentes.

É importante chamar atenção para alguns aspectos que não foram explorados neste estudo, assim como para potenciais limitações. As informações sobre etnia e língua dos indígenas captadas no Censo de 2010 não estão disponíveis nos microdados da amostra, de modo que não foi possível incluí-las. Os índices de qualidade de dados (Myers, Whipple, das Nações Unidas, dentre outros) - amplamente utilizados em trabalhos sobre idade a partir de levantamentos censitários (Horjales, Koolhaas G Nathan, 2012; Horta, 2012; Pereira, Filho G Sá, 2012; Hobbs, 2004; ONU, 1955) - não foram aqui estudados, pois o foco das análises incidiu no tipo de declaração de idade. Quanto aos critérios de seleção da amostra investigada, alcançou-se uma cobertura mais expressiva da população indígena em área rural (51,5\% do total de indígenas no país), quando comparada à área urbana (16,5\%).

Os resultados aqui descritos evidenciam que há diferença nas respostas sobre a forma de declaração de idade na população indígena em comparação ao segmento não indígena nos municípios investigados. As variáveis situação de domi- 
cílio e tipo de informante se mostraram particularmente importantes nos padrões de respostas. Ainda que este capítulo tenha trazido novos subsídios na interpretação dos dados sobre idade na população indígena a partir do Censo de 2010, um importante passo adicional seria investigar questões ligadas a pertencimento étnico e língua, entre outras variáveis de ordem sociocultural. Tais análises, sem dúvida, permitirão uma compreensão mais matizada acerca dos complexos fatores envolvidos nas declarações de idade desse segmento, em particular por levar em consideração a sociodiversidade indígena existente no Brasil.

\section{Referências}

AZEVEDO, M. M. Saúde reprodutiva e mulheres indígenas do Alto Rio Negro. Caderno CRH, 22 (57): 463-477, 2009.

AZEVEDO, M. M. O Censo Demográfico 2010 e os povos indígenas. In: RICARDO, C. A. G RICARDO, F. (Orgs.). Povos Indígenas do Brasil 2006/2010. São Paulo: Instituto Socioambiental, 2011

BORGES, A. S. et al. Captando informações da população indígena nos censos demográficos: o caso da aldeia de Santa Rosa do Ocoy. In: ENCONTRO NACIONAL DE ESTUDOS POPULACIONAIS, XVII, Caxambu, 2010.

BORGES, J. C. O Retorno da Velha Senhora ou a Categoria de Tempo entre os Krahô, 2004. Dissertação de Mestrado, Brasília: Universidade de Brasília.

CALDAS, A. D. R. et al. Mortalidade infantil segundo cor ou raça com base no Censo Demográfico de 2010 e nos sistemas nacionais de informação em saúde no Brasil. Cadernos de Saúde Pública, 33(7): 1-13, 2017.

CARDOSO, A. M.; SANTOS, R. V. G COIMBRA, C. E. A. Mortalidade infantil segundo raça/ cor no Brasil: o que dizem os sistemas nacionais de informação?. Cadernos de Saúde Pública, 21(5): 1.602-1.608, 2005.

CAVENAGHI, S. G ALVES, J. Domicilios y familias en la experiencia censal del Brasil: cambios y propuesta para identificar arreglos familiares. Notas de Población, 92: 15-46, 2011.

COIMBRA, C. E. A. et al. The Xavante in Transition: health, ecology and bioanthropology in Central Brazil. Ann Arbor: University of Michigan Press, 2002.

COIMBRA, C. E. A. et al. The first national survey of indigenous people's health and nutrition in Brazil: rationale, methodology, and overview of results. BMC Public Health, 13 13-52, 2013.

EARLY, J. D. G PETERS, J. F. The Population Dynamics of the Mucajaí Yanomama. San Diego: Academic Press, 1990. 
FLOWERS, N. M. Crise e recuperação demográfica: os Xavante de Pimentel Barbosa, Mato Grosso. In: SANTOS, R. V. G COIMBRA, E. A. (Orgs.). Saúde e Povos Indígenas. Rio de Janeiro: Editora Fiocruz, 1994.

FUNDAÇÃO NACIONAL DO ÍNDIO (FUNAI). Listagem de terras indígenas, 2011. Disponível em: <http://6ccr.pgr.mpf.mp.br/documentos-e-publicacoes/terras-indigenas/tis/listagem de-terras-indigenas-funai-2011.xls/view> Acesso em: 14 out. 2013.

GONÇALVES, J. M. M. IBGE: um retrato histórico. Rio de Janeiro: IBGE, Departamento de Documentação e Biblioteca, 1995.

HOBBS, F. Age and sex composition. In: SIEGEL, J. G SWANSON, D. (Eds.). The Methods and Materials of Demography. London: Elsevier Academic Press, 2004.

HORJALES, R.; KOOLHAAS, M. G NATHAN, M. Análisis de la calidad de la edad declarada en los censos de población de Uruguay. In: ENCONTRO LATINO AMERICANO DE ESTUDOS POPULACIONAIS, XVIII, 2012, Montevideo.

HORTA, C. J. G. Idade declarada nos censos demográficos e a qualidade da informação. In: ENCONTRO BRASILEIRO DE ESTUDOS POPULACIONAIS, XVIII, 2012, Águas de Lindoia.

HORTA, C. J. G.; SAWYER, D. R. T. O. G CARVALHO, J. S. M. de. Ajuste das estruturas de mortalidade para Brasil, unidades da federação, regiões metropolitanas e capitais. In: ENCONTRO NACIONAL DE ESTUDOS POPULACIONAIS, XV, 2006, Caxambu.

HOWELL, N. Demography of the Dobe! Kung. New York: Walter de Gruter, 1979.

INSTITUTO BRASILEIRO DE GEOGRAFIA E ESTATÍsTICA (IBGE). Uma Análise dos Indígenas com Base nos Resultados da Amostra dos Censos Demográficos 1991 e 2000. Rio de Janeiro: IBGE, 2005.

INSTITUTO BRASILEIRO DE GEOGRAFIA E ESTATÍSTICA (IBGE). Síntese das Etapas da Pesquisa. Rio de Janeiro: IBGE, 2010a.

INSTITUTO BRASILEIRO DE GEOGRAFIA E ESTATÍsTICA (IBGE). Pesquisa de Avaliação da Cobertura da Coleta: manual do recenseador PA - 1.09. Rio de Janeiro: IBGE, 2010b.

INSTITUTO BRASILEIRO DE GEOGRAFIA E ESTATÍSTICA (IBGE). Censo Demográfico 2010: características da população e dos domicílios - resultados do universo. Rio de Janeiro: IBGE, 2011.

INSTITUTO BRASILEIRO DE GEOGRAFIA E ESTATÍSTICA (IBGE). Os Indígenas no Censo Demográfico 2010: primeiras considerações com base no quesito cor ou raça. Rio de Janeiro: IBGE, 2012a.

INSTITUTO BRASILEIRO DE GEOGRAFIA E ESTATÍSTICA (IBGE). Características Gerais dos Indígenas no Censo Demográfico 2010: resultados do universo. Rio de Janeiro: IBGE, 2012b.

INSTITUTO BRASILEIRO DE GEOGRAFIA E ESTATÍSTICA (IBGE). Censo Demográfico 2010: resultados gerais da amostra. Rio de Janeiro: IBGE, 2012c. 
JANNUZZI, P. D. M. Indicadores para diagnóstico, monitoramento e avaliação de programas sociais no Brasil. Revista do Serviço Público Brasília, 56(2): 137-160, 2005.

JARDIM, R.; BARRETO, S. G GIATTI, L. Confiabilidade das informações obtidas de informante secundário em inquéritos de saúde. Cadernos de Saúde Pública, 26(8): 1.537-1.548, 2010.

MARINHO, G. L.; SANTOS R. V. G PEREIRA, N. O. M. Classificação dos domicílios "indígenas" no Censo Demográfico 2000: subsídios para a análise de condições de saúde. Revista Brasileira de Estudos Populacionais, 28(2): 449-466, 2011.

MÉDICI, A. C. Sistema estatístico, planejamento e sociedade no Brasil (notas para uma discussão). Revista Brasileira de Estudos Populacionais, 7(2): 191-206, 1990.

OLIVEIRA, J. S. "Brasil mostra tua cara": imagens da população brasileira nos Censos Demográficos de 1872 a 2000. Escola Nacional de Ciências Estatísticas (textos para discussão), 6: $1-75,2003$.

ORGANIZAÇÃO DAS NAÇÕES UNIDAS (ONU). Manual II: methods of appraisal of quality of basic data for population estimates. New York: United Nations, 1955.

PAES, N. A. G ALBUQUERQUE, M. E. E. Avaliação da qualidade dos dados populacionais e cobertura dos registros de óbitos para as regiões brasileiras. Revista de Saúde Pública, 33(1): 33-43, 1999.

PAGliARO H.; AZEVEDO, M. M. G SANTOS, R. V. (Orgs.). Demografia dos Povos Indígenas no Brasil. Rio de Janeiro: Editora Fiocruz, Associação Brasileira de Estudos Populacionais, 2005.

PAGLIARO, H.; MENDONÇA, S. G BARUZZI, R. Fecundidade e saúde reprodutiva das mulheres Suyá (Kisêdjê): aspectos demográficos e culturais. Caderno CRH, 22(57): 479-491, 2009.

PEREIRA, N. O. M. G AZEVEDO, M. M. Os povos indígenas e os censos do IBGE: uma experiência brasileira. In: CONGRESSO DA ASSOCIAÇÃO LATINO-AMERICANA DE POPULAÇÃO, I, 2004, Caxambu.

PEREIRA, N. O. M.; MAIA FILHO, R. G SÁ, M. Avaliação das variáveis sexo e idade nas informações censitárias. In: ENCONTRO BRASILEIRO DE ESTUDOS POPULACIONAIS, XVIII, 2012, Águas de Lindoia.

SANTANA, V. et al. Confiabilidade e viés do informante secundário na pesquisa epidemiológica: análise de questionário para triagem de transtornos mentais. Revista de Saúde Pública, 31(6): 556-565, 1997.

SANTIAGO, C. D. J. G VERONA, A. P. Perfil religioso da população autodeclarada indígena no Brasil: considerações a partir do Censo Demográfico de 2010. Horizonte, 12(36): 1.140-1.159, 2014.

SANTOS R. V. G TEIXEIRA P. O indígena que emerge do Censo Demográfico de 2010. Cadernos de Saúde Pública, 27(6): 1.048-1.049, 2011. 
SANTOS, R. V. et al. Parity of indigenous and non-indigenous women in Brazil: does the reported number of children born depend upon who answers national census questions? Plos One, 10(4): 1-15, 2015.

SANTOS R. V. et al. The identification of the indigenous population in Brazil's official statistics, with an emphasis on demographic censuses. Statistical Journal of the IAOS, 35(1): 26-49, 2019.

SOUZA, L. G. G SANTOS, R. V. Perfil demográfico da população indígena Xavante de Sangradouro-Volta Grande, Mato Grosso (1993-1997), Brasil. Cadernos de Saúde Pública, 17(2): 355-365, 2001.

WARREN, J. G KENNEDY, D. P. Contributions of racial-ethnic reclassification and demographic processes to indigenous population resurgence: the case of Brazil. Latin American Research Review, 43(2): 7-33, 2008.

WERNER, D. Fertility and pacification among the Mekranoti of Central Brazil. Human ECology, 11(2): 227-245, 1983. 


\section{Parturição em Mulheres Indígenas e Não Indígenas do Brasil: o número de filhos relatados depende de quem responde às perguntas do censo nacional?*}

Ricardo Ventura Santos

João Luiz Bastos

Oswaldo Gonçalves Cruz

Luciene Aparecida Ferreira de Barros Longo

Nancy May Flowers

Nilza de Oliveira Martins Pereira

Em razão das trajetórias históricas distintas, das variadas formas de classificação e da falta de dados estatísticos confiáveis, estimar o tamanho das populações indígenas ao redor do mundo se impõe como uma tarefa de considerável complexidade (Axelsson G Sköld, 2011; Paho, 2006; UN, 2009). Em meio ao reconhecimento dessa complexidade, observa-se uma preocupação crescente com os dados de natureza demográfica e de saúde desses grupos étnicos específicos, os quais tendem a apresentar piores condições de vida do que as sociedades nacionais que compartilham do mesmo território. Com o objetivo de descrever as condições de vida e avaliar a magnitude das desigualdades em suas dimensões demográficas e de saúde, agências internacionais têm encorajado países das mais variadas regiões do planeta a incluir questões voltadas para as condições sociodemográficas dos povos indígenas em suas pesquisas censitárias de abrangência nacional (Paho, 2006; UN, 2009).

Estima-se que há mais de 400 diferentes grupos indígenas na América Latina e no Caribe, com uma população total de cerca de 50 milhões de indivíduos (McSweeney G Arps, 2005; Montenegro G Stephens, 2006). Enquanto mais de 40\% da população da Bolívia, Equador, Guatemala e Peru se declara indígena, na Argentina, Brasil, Costa Rica e Uruguai, os povos indígenas perfazem menos de $1 \%$ do contingente populacional total de cada um desses países (Montenegro G Stephens, 2006). De modo semelhante ao que ocorre em diversas regiões do mundo, os povos indígenas da América Latina estão submetidos a piores condições de vida, menores níveis de escolaridade, maiores taxas de mortalidade, bem como a outras condições sociais e de saúde desfavoráveis, se comparados com suas respectivas sociedades nacionais (Coimbra G Santos, 2004; Incayawar G Maldonado-Bouchard, 2009; McSweeney G Arps, 2005; Montenegro G Stephens, 2006; Paho, 2006).

Em paralelo, a maior parte dos países latino-americanos tem incluído, e efetivamente expandido, o número de questões sobre os povos indígenas em suas pesquisas censitárias nacionais nas últimas décadas. A quantidade de perguntas, bem como o seu conteúdo específico, varia de país para país, embora um aspecto 
comum tenha sido a iniciativa de coletar dados sobre o tamanho das populações indígenas e suas filiações étnicas. O caso brasileiro é ilustrativo dessa tendência. Tendo sido incluída pela primeira vez em 1991, a categoria "indígena" passou a figurar entre as opções de resposta para o quesito cor/raça dos censos conduzidos no país desde então. Além disso, no Censo de 2010, os respondentes que optaram pela categoria "indígena" do quesito cor/raça também foram indagados a respeito da filiação étnica e das línguas nativas faladas em seus domicílios (IBGE, 2005, 2012; Santos G Teixeira, 2011).

É inquestionável que a inclusão de características demográficas dos povos indígenas nos censos nacionais de países latino-americanos e de outras regiões representa um expressivo avanço em direção a uma melhor compreensão das suas condições de vida e, portanto, à implementação e avaliação dos impactos de uma ampla variedade de políticas públicas (Del Popolo, 2008; Del Popolo et al., 2011; Montenegro G Stephens, 2006; UN, 2009). Contudo, é também importante reconhecer que, em graus variáveis, as características socioculturais das sociedades indígenas, em conjunto com determinados procedimentos metodológicos empregados nos censos nacionais, podem influenciar o modo como indígenas respondem às questões apresentadas pelos recenseadores (Axelsson G Sköld, 2011). No caso brasileiro, por exemplo, diversas comunidades indígenas contam com apenas alguns (ou nenhum) indivíduos fluentes em português, a língua oficialmente utilizada nas entrevistas censitárias (IBGE, 2012). Outros aspectos culturais que podem afetar o relato de informações aos recenseadores dizem respeito aos sistemas numéricos, os quais são distintos do sistema decimal comumente empregado nas análises demográficas oficiais, especialmente nas comunidades que retêm suas línguas nativas. Isso também se estende aos sistemas indígenas de atribuição de idade, os quais raramente se baseiam na data de nascimento (Pagliaro, Azevedo G Santos, 2005), como o faz o censo brasileiro. Dessa forma, sempre que possível, a influência desses fatores deve ser considerada na apreciação dos dados censitários referentes aos povos indígenas.

Tendo-se a parturição como variável de interesse primário, o objetivo deste capítulo é investigar se os padrões de resposta ao censo diferem entre indígenas e não indígenas, quando essa informação é provida diretamente pela mulher ou por um respondente proxy (morador ou não do próprio domicílio). Com esse propósito, utilizamos dados sobre o número de filhos relatados por mulheres indígenas e não indígenas de duas regiões brasileiras, especificamente o Norte e o Nordeste. Tais regiões foram selecionadas por diferirem marcadamente em termos de características antropológicas e históricas de seus povos indígenas, como, por exemplo, uma proporção expressivamente maior de indígenas falando suas línguas nativas no Norte do que no Nordeste, entre outras importantes distinções. Espera-se que nossa análise indique os fatores que podem ter influenciado parte dos resultados do 
Censo Demográfico 2010, subsidiando, portanto, o planejamento e a implementação de futuras iniciativas voltadas para a coleta de dados em comunidades indígenas e outros segmentos populacionais. Em uma dimensão mais ampla, nosso trabalho contribui para uma reflexão crítica acerca da maneira como os dados sobre minorias étnicas indígenas, que estão entre as populações mais marginalizadas do mundo em termos de saúde e direitos humanos, têm sidos coletados pelos Estados nacionais.

\section{Fontes de dados e análises realizadas}

No Brasil, os censos demográficos nacionais têm sido conduzidos desde a segunda metade do século XIX. A partir de 1940, o Instituto Brasileiro de Geografia e Estatística (IBGE) se tornou o órgão federal responsável pelos censos, que são conduzidos em intervalos regulares de dez anos (Gonçalves, 1995; IBGE, 2006; Nobles, 2000).

O Censo Demográfico 2010 empregou dois tipos de questionário. O questionário básico foi aplicado ao universo da população brasileira, enquanto o questionário da amostra foi administrado em um subgrupo de respondentes derivado do próprio censo. O primeiro abrangeu uma quantidade limitada de características dos domicílios investigados (em sua maior parte, relacionadas à composição domiciliar e aspectos ligados ao saneamento), bem como de seus próprios residentes, incluindo, por exemplo, idade, sexo, cor/raça, alfabetização e renda. Todas as perguntas do questionário básico fizeram parte do questionário da amostra, o qual também abordou itens sobre ocupação, fecundidade e migração, entre outros. Detalhes de cada um dos questionários podem ser conferidos na página <http://censo2010.ibge.gov.br>.

Em cada domicílio, um único indivíduo foi entrevistado (geralmente, um adulto identificado como o chefe do domicílio em questão), que deveria prover informações sobre si mesmo e sobre todos os demais moradores. Segundo os procedimentos metodológicos do Censo 2010, um não morador do domicílio também poderia, caso necessário, prover informações sobre seus membros. Com o objetivo de identificar esses diferentes respondentes, a base de dados do Censo 2010 incluiu a variável denominada "tipo de respondente" ou "marca", com as seguintes possibilidades de classificação: 1) a informação foi dada diretamente pelo entrevistado, isto é, foi autorrelatada; 2) a informação sobre algum membro do domicílio foi fornecida por outro morador; 3) a informação sobre algum morador foi provida por um não morador (frequentemente, uma trabalhadora doméstica que estava no local, por ocasião da visita do recenseador, quando nenhum residente estava presente). Num total de cerca de 190 milhões de brasileiros recenseados, 4,2\% deles, em média, tiveram suas informações fornecidas por não moradores de seus próprios domicílios. 
O Censo Demográfico 2010 foi o primeiro na história do país a conduzir as entrevistas com o auxílio de dispositivos do tipo Personal digital assistant, um aparelho eletrônico móvel que armazena e organiza informações, evitando o uso de questionários impressos. Além disso, diferentemente do que ocorreu em edições prévias, o Censo 2010 foi o primeiro a incluir o quesito cor/raça no questionário básico, aplicando-o à totalidade da população do país. Entre outros avanços importantes na coleta de dados, esse censo também coletou informação sobre filiação étnica para todos os declarados indígenas (IBGE, 2012), línguas indígenas faladas no domicílio e residência em reservas indígenas reconhecidas pelo governo federal. O quesito cor/raça dividiu a população em cinco categorias: branca, preta, amarela, parda e indígena (IBGE, 2013). Os respondentes poderiam ignorar essa pergunta, situação na qual seriam classificados com cor/raça "desconhecida". Tais indivíduos somaram menos de $0,1 \%$ do total da população e foram excluídos das análises do presente trabalho.

Os recenseadores que participaram da coleta de dados de 2010 não receberam treinamento específico para conduzir entrevistas em áreas indígenas (IBGE, 2013). Entretanto, o material desenvolvido pelo IBGE incluiu orientações específicas destinadas a uma melhor compreensão dos povos indígenas e seus domicílios, com foco nos padrões de habitação, práticas religiosas e atividades econômicas locais, tendo em vista que esses tópicos seriam abordados em parte das perguntas do questionário (IBGE, 2010a, 2013). Em regiões do país com maiores concentrações de terras indígenas (TIs), o IBGE também disponibilizou folhetos aos entrevistadores com informações gerais sobre os povos indígenas, preparados em colaboração com antropólogos e demógrafos vinculados ao Grupo de Trabalho Demografia dos Povos Indígenas no Brasil da Associação Brasileira de Estudos Populacionais. A motivação principal para a confecção dos folhetos foi sensibilizar os entrevistadores para os distintos padrões culturais e sociais com os quais poderiam ter contato nos territórios indígenas, incluindo o encontro de indivíduos completamente despidos até a expectativa de que se apresentassem aos líderes locais previamente à condução das entrevistas do censo.

Para desenvolver o presente estudo, um subconjunto de variáveis de nível individual do Censo 2010 foi convertido para o formato Stata (programa estatístico para uso em computadores pessoais), abarcando as seguintes informações: estrutura amostral (incluindo os setores censitários individuais como unidades primárias de amostragem e grupos contíguos de setores censitários como estratos), pesos amostrais, situação urbana/rural, número de moradores e quantidade de cômodos do domicílio, cor/raça, escolaridade, situação conjugal e idade. A principal variável de interesse - parturição ou a contagem de todos os filhos relatados por uma mulher ao longo de sua vida reprodutiva - também integrou o conjunto de variáveis e foi definida pelo número de filhos nascidos vivos até julho de 2010, tal como informada aos recenseadores. 
As análises foram restritas às mulheres acima dos 10 anos de idade residindo na região Norte ou Nordeste do país. Tais regiões foram selecionadas para comparação, pois os povos indígenas que nelas residem apresentam diferenças sócio-históricas de particular importância para este trabalho. Enquanto os indígenas do Nordeste foram os primeiros a sofrer os impactos da chegada dos europeus no século XVI, os do Norte, região que apresenta grande sobreposição com a Amazônia, passaram a interagir com não indígenas num período mais recente, especialmente a partir do século XX (Hemming, 1987; Ricardo G Ricardo, 2011). Como resultado dessas trajetórias históricas complexas e, ao mesmo tempo, distintas, uma maior quantidade de grupos indígenas do Norte ainda fala suas línguas nativas, reside em reservas e mantém sistemas econômicos baseados em práticas de subsistência (Hemming, 1987; Ricardo G Ricardo, 2011). Dados os vários séculos de presença não indígena no Nordeste, os povos indígenas que lá residem não apenas perderam a maior parte de seus territórios tradicionais, mas também passaram por transformações culturais que culminaram na extinção de suas línguas nativas. Enquanto 55,2\% dos declarados indígenas do Norte relataram falar alguma língua nativa em seus domicílios, tal percentual foi de 13,6\% no Nordeste (IBGE, 2012). A região Norte também conta com o maior contingente populacional indígena do país (342.836 indivíduos de um total de 896.917 em todo o Brasil). Por sua vez, a população do Nordeste inclui um número expressivo de indígenas, 126.597 indivíduos, sendo que a maior parte deles vive fora de áreas de reserva (IBGE, 2012). Por fim, a região Norte dispõe do maior percentual $(82,0 \%)$ de grupos indígenas em áreas rurais (IBGE, 2012).

O primeiro passo da análise estatística consistiu na descrição de cada grupo de cor/raça, em ambas as regiões investigadas, de acordo com a situação urbana/rural, escolaridade e idade. Em seguida, dois importantes parâmetros deste estudo, isto é, (1) a frequência de entrevistas segundo cada tipo de respondente e (2) a parturição, foram estimados - de acordo com a situação urbano/rural, cor/ raça, idade (em faixas etárias até 60 anos ou mais) e escolaridade (desde analfabeto até ensino superior completo, incluindo uma categoria para escolaridade não registrada) - para o Norte e para o Nordeste, separadamente. A parturição também foi estimada de acordo com o tipo de respondente. A associação entre cor/raça e parturição, bem como o impacto do tipo de respondente sobre essa relação foram avaliados com modelos de regressão binomial negativa inflacionada de zeros (BNIZ), estratificando-se para região (Norte e Nordeste) e situação urbano/rural.

Como forma de avaliar se a associação entre cor/raça e parturição diferiu em decorrência do tipo de respondente, um termo de interação entre essas variáveis foi acrescentado às equações de regressão. A inclusão desse termo procurou testar a hipótese de que mulheres indígenas teriam menor chance de, relativamente às não indígenas, relatar suas informações diretamente aos recenseadores devido à menor fluência em português e a dinâmicas de gênero específicas (expressas, por 
exemplo, na tendência de homens a interagirem mais frequentemente com visitantes não indígenas em seus territórios). Isso aumentaria a chance de que as informações sobre a história reprodutiva das mulheres fossem fornecidas por diversos indivíduos, tais como, outros membros do domicílio ou, mesmo, algum não morador das residências abordadas. Os critérios de informação de Bayes e de Akaike indicaram que os modelos com o termo de interação apresentaram melhor ajuste aos dados.

As covariáveis incluídas nos modelos foram: idade, escolaridade, número de cômodos do domicílio (número que variou de 1 a 30) e total de moradores da residência (variável numérica discreta com amplitude de 1 a 56). Todas as variáveis independentes foram mantidas nos modelos, não importando o seu impacto nas estimativas de ajuste. Objetivando facilitar a interpretação, apenas os coeficientes para contagem de filhos são discutidos neste capítulo. A média de filhos predita pelos modelos, juntamente com seus intervalos de confiança de 95\% (IC95\%), de acordo com cor/raça e tipo de respondente, também foi estimada, estratificando-se para região e situação urbano/rural, após ajuste para as demais covariáveis. Todas as análises levaram em consideração a amostragem complexa, bem como os pesos amostrais, tal como recomendado pelo IBGE. ${ }^{1}$

\section{Achados do estudo}

A análise abrangeu 6.290.856 mulheres acima de 10 anos de idade na região Norte do Brasil, e 22.817.444 no Nordeste (Tabela 1). A proporção de mulheres declaradas brancas, pretas, amarelas, pardas e indígenas em cada região, respectivamente, foi de: Norte $-24,0 \%, 6,2 \%, 1,3 \%, 66,9 \%$ e 1,6\%; Nordeste $29,6 \%, 9,4 \%, 1,4 \%, 59,2 \%$ e $0,4 \%$. Entre os respondentes da região Norte, 76,3\% das mulheres declaradas pardas e $83,2 \%$ das amarelas residiam em áreas urbanas, ao passo que a maioria das mulheres indígenas $(75,7 \%)$ residia em áreas rurais. Entretanto, o percentual de mulheres indígenas residindo em situação urbana foi consideravelmente maior no Nordeste $(57,7 \%)$. A proporção de não indígenas em áreas urbanas no Nordeste variou entre 73,0\% (pardas) e 79,8\% (brancas), valores ligeiramente mais baixos do que o observado no Norte.

A Tabela 1 demonstra igualmente que, entre todos os grupos investigados nas duas regiões, mulheres indígenas apresentaram os menores níveis de escolaridade. No Norte e no Nordeste, $82,4 \%$ e 64,3\% eram analfabetas ou tinham apenas ensino fundamental incompleto, respectivamente. Mulheres declaradas pretas e pardas ocuparam posição intermediária em termos de escolarização, ao passo que as classificadas como amarelas e brancas apresentaram maiores níveis de educação formal. As indígenas também tenderam a ser mais jovens, concentrando-se nas duas primeiras categorias de faixa etária: 10-14 e 15-19 anos. 
Em ambas as regiões estudadas, pouco mais da metade das entrevistadas responderam aos recenseadores diretamente (51,2\% no Norte e $54,4 \%$ no Nordeste) (Tabela 2). Em outras palavras, 45,6\% a 48,8\% das entrevistas foram conduzidas por respondentes proxy, os quais poderiam ser tanto outro morador quanto um não morador do próprio domicílio. O percentual de mulheres que respondeu diretamente aos entrevistadores foi um pouco maior nas áreas rurais, especialmente no Norte (55,6\%), o mesmo ocorreu com mulheres mais velhas, especificamente aquelas entre 50 e 59 anos. A associação entre tipo de respondente e escolaridade não seguiu um padrão consistente e claro. Mulheres indígenas do Norte tiveram a maior porcentagem de entrevistas realizadas com um não morador de seus domicílios (12,7\% no total; $15,0 \%$ e 3,0\% em áreas rurais e urbanas, respectivamente). É digno de nota que os demais grupos de cor/raça da região Norte apresentaram, relativamente, frequências bastante baixas de entrevistas realizadas com não moradores: brancas $-4,0 \%$, pretas $-2,9 \%$, amarelas $-2,5 \%$ e pardas $-3,0 \%$. Em comparação com a região Norte, as frequências de respostas dadas pelas próprias mulheres, por outro morador ou não morador do domicílio variaram menos entre indígenas e não indígenas do Nordeste.

A Tabela 3 contém as médias de parturição, conforme situação urbana/ rural, escolaridade, cor/raça, idade e tipo de respondente no Norte e no Nordeste. Essas contagens médias foram ligeiramente mais elevadas no Nordeste (2,15 filhos) do que no Norte (2,08 filhos). A parturição foi maior nas áreas rurais, em grupos de menor escolaridade e, conforme esperado, entre as mulheres mais velhas. As mulheres indígenas apresentaram a maior média de filhos, sendo imediatamente seguidas pelas pretas. Mulheres declaradas brancas e amarelas tiveram as menores médias de parturição. Independentemente de cor/raça, as médias foram consideravelmente mais elevadas quando essa informação foi provida pela própria mulher - tais valores foram 93,5\%-101,4\% maiores, quando comparados com aqueles informados por outros moradores dos domicílios, e 15,6\%-21,7\% maiores, em contraste com o relatado por um não morador.

Quando a parturição foi estimada no contexto de modelos de regressão BNIZ, ajustados para todas as covariáveis, as mulheres indígenas contaram com médias 18\%-39\% maiores, relativamente às brancas (Tabela 4). Ao se considerarem todos os grupos de cor/raça em conjunto, observou-se que as médias de parturição foram mais baixas quando informadas por outros moradores do domicílio, em comparação com a situação em que as próprias mulheres forneceram tal informação: as diferenças variaram entre 1,0\% (Norte rural) a 7,0\% (Nordeste urbano). O termo de interação entre cor/raça e tipo de respondente revelou um aspecto central desta análise: mulheres indígenas do Norte rural, cujas respostas ao censo foram dadas por um não morador apresentaram uma contagem de filhos $16 \%$ menor $(0,84$, IC95\% 0,75-0,93), se comparadas com as brancas que proveram essa informação 
diretamente aos entrevistadores. Essa foi a maior diferença detectada entre todos os grupos comparados, tanto no Norte quanto no Nordeste. Apesar de as diferenças para as indígenas e amarelas do Norte urbano serem ainda maiores $(0,78$ e 0,82, respectivamente), tais resultados não foram estatisticamente significativos. No que se refere à parturição para indígenas, suas estimativas foram 10,0\% (0,90, IC95\% 0,82-0,99) e 7,0\% (0,93, IC95\% 0,88-0,99) menores em áreas urbanas e rurais, respectivamente, quando a contagem de filhos foi informada por outro morador do domicílio (essas comparações têm mulheres brancas, que responderam diretamente ao recenseador, como categoria de referência). Houve uma associação negativa entre parturição e escolaridade, bem como uma relação positiva com idade. Nem o total de cômodos, nem o número de moradores dos domicílios estiveram associados com a parturição.

As estimativas de parturição preditas pelos modelos de regressão, ilustradas nos Gráficos 1 e 2, sugerem que esse parâmetro é afetado pelo tipo de respondente em todos os grupos de cor/raça, tanto nas áreas urbanas quanto nas rurais das duas regiões investigadas. Em geral, o tipo de respondente apresentou um impacto semelhante nas médias de parturição em todos os grupos de cor/raça do Nordeste, com as estimativas mais baixas derivando de outros moradores dos domicílios, enquanto as mais altas foram informadas diretamente pelas mulheres (Gráfico1). Na maior parte das vezes, as médias não diferiram quando comparados outros moradores e não moradores dos domicílios, tendo em vista a sobreposição dos intervalos de confiança. Em termos comparativos, o impacto do tipo de respondente sobre as contagens médias de filhos foi maior para as mulheres indígenas do Norte, especialmente nas áreas rurais (Gráfico 2). Se, por um lado, a parturição média foi de 3,1 (IC95\% 3,0-3,2) nas áreas rurais do Norte (quando essa informação foi fornecida pela própria mulher), por outro, a mesma estimativa ficou em torno de 2,4 (IC95\% 2,3-2,6) para outro morador e não morador dos domicílios investigados. No Norte urbano, as médias de parturição foram um pouco maiores quando estimadas para as mulheres que proveram essa informação diretamente aos entrevistadores $(2,6$, IC95\% 2,5-2,8), relativamente à situação em que tal dado foi fornecido por outro morador (2,1, IC95\% 1,9-2,2) ou não morador do domicílio $(2,0$, IC95\% $1,4-2,5)$. 
Tabela 1 - Distribuição relativa da amostra por situação urbana/rural, escolaridade e idade, de acordo com cor/raça, estratificada por região. Regiões Norte e Nordeste - Brasil - 2010

\begin{tabular}{|c|c|c|c|c|c|c|c|c|c|c|}
\hline \multirow{3}{*}{ Variável } & \multicolumn{10}{|c|}{ Cor/raça - \% } \\
\hline & \multicolumn{5}{|c|}{ Norte } & \multicolumn{5}{|c|}{ Nordeste } \\
\hline & Branca & Preta & Amarela & Parda & Indígena & Branca & Preta & Amarela & Parda & Indígena \\
\hline \multicolumn{11}{|l|}{ Situação urbana/rural } \\
\hline Urbana & 82,5 & 76,7 & 83,2 & 76,3 & 24,3 & 79,8 & 78,8 & 77,7 & 73,0 & 57,7 \\
\hline Rural & 17,5 & 23,3 & 16,8 & 23,7 & 75,7 & 20,2 & 21,2 & 22,3 & 27,0 & 42,3 \\
\hline \multicolumn{11}{|l|}{ Escolaridade } \\
\hline $\begin{array}{l}\text { Analfabeto/ensino } \\
\text { primário incompleto }\end{array}$ & 45,5 & 57,8 & 44,7 & 54,6 & 82,4 & 48,5 & 58,4 & 50,9 & 58,4 & 64,3 \\
\hline $\begin{array}{l}\text { Ensino fundamental } \\
\text { completo/ ensino médio } \\
\text { incompleto }\end{array}$ & 17,0 & 16,2 & 19,2 & 17,5 & 8,7 & 15,6 & 15,2 & 17,1 & 16,1 & 15,2 \\
\hline $\begin{array}{l}\text { Ensino médio completo/ } \\
\text { ensino superior } \\
\text { incompleto }\end{array}$ & 29,7 & 20,5 & 28,1 & 22,4 & 7,2 & 25,4 & 22,0 & 25,2 & 20,6 & 16,4 \\
\hline $\begin{array}{l}\text { Ensino superior } \\
\text { completo }\end{array}$ & 10,1 & 5,0 & 7,1 & 4,8 & 1,2 & 10,0 & 3,9 & 6,2 & 4,4 & 3,7 \\
\hline Não informada & 0,7 & 0,5 & 0,9 & 0,7 & 0,5 & 0,5 & 0,5 & 0,6 & 0,5 & 0,4 \\
\hline \multicolumn{11}{|l|}{ Idade (anos) } \\
\hline $10-14$ & 12,3 & 11,2 & 11,1 & 14,4 & 19,2 & 10,4 & 9,1 & 10,0 & 12,1 & 13,2 \\
\hline $15-19$ & 12,3 & 11,3 & 13,0 & 13,3 & 15,6 & 10,5 & 9,9 & 11,8 & 11,7 & 12,5 \\
\hline $20-29$ & 23,4 & 24,0 & 28,6 & 24,3 & 23,2 & 21,2 & 22,2 & 25,2 & 22,1 & 20,4 \\
\hline $30-39$ & 19,2 & 19,1 & 21,4 & 18,8 & 16,2 & 17,6 & 18,7 & 19,4 & 17,8 & 17,6 \\
\hline $40-49$ & 13,7 & 13,7 & 12,3 & 12,8 & 10,0 & 14,6 & 14,9 & 13,8 & 14,1 & 13,8 \\
\hline $50-59$ & 9,1 & 9,9 & 6,5 & 8,4 & 6,6 & 10,4 & 11,1 & 8,8 & 10,1 & 9,2 \\
\hline $60+$ & 9,1 & 10,8 & 7,1 & 8,0 & 9,2 & 15,3 & 14,1 & 11,0 & 12,1 & 13,3 \\
\hline Total (n) & $\begin{array}{r}100,0 \\
(1.505 .492)\end{array}$ & $\begin{array}{r}100,0 \\
(390.747)\end{array}$ & $\begin{array}{r}100,0 \\
(81.798)\end{array}$ & $\begin{array}{r}100,0 \\
(4.210 .557)\end{array}$ & $\begin{array}{r}100,0 \\
(102.262)\end{array}$ & $\begin{array}{r}100,0 \\
(6.768 .722)\end{array}$ & $\begin{array}{r}100,0 \\
(2.151 .841)\end{array}$ & $\begin{array}{r}100,0 \\
(310.191)\end{array}$ & $\begin{array}{r}100,0 \\
(13.501 .871)\end{array}$ & $\begin{array}{r}100,0 \\
(84.819)\end{array}$ \\
\hline
\end{tabular}


Tabela 2 - Frequência relativa de tipo de respondente do Censo 2010, conforme situação urbana/rural, escolaridade, cor/raça e idade, estratificada por região. Regiões Norte e Nordeste - Brasil - 2010

\begin{tabular}{c|c|c|c|c|c|c}
\multirow{2}{*}{ Variável } & \multicolumn{5}{|c}{ Tipo de respondente } \\
\cline { 2 - 6 } & \multicolumn{3}{|c|}{ Norte } \\
\cline { 2 - 6 } & $\begin{array}{c}\text { A } \\
\text { própria } \\
\text { mulher }\end{array}$ & $\begin{array}{c}\text { Outro } \\
\text { morador do } \\
\text { domicílio }\end{array}$ & $\begin{array}{c}\text { Não } \\
\text { morador do } \\
\text { domicílio }\end{array}$ & $\begin{array}{c}\text { A } \\
\text { própria } \\
\text { mulher }\end{array}$ & $\begin{array}{c}\text { Outro } \\
\text { morador do } \\
\text { domicílio }\end{array}$ & $\begin{array}{c}\text { Não } \\
\text { morador do } \\
\text { domicílio }\end{array}$ \\
\hline
\end{tabular}

Situação urbana/rural

\begin{tabular}{|c|c|c|c|c|c|c|}
\hline Urbana & 49,9 & 46,8 & 3,3 & 53,4 & 43,0 & 3,6 \\
\hline Rural & 55,6 & 40,8 & 3,6 & 57,6 & 39,3 & 3,1 \\
\hline \multicolumn{7}{|l|}{ Escolaridade } \\
\hline $\begin{array}{l}\text { Analfabeto/ensino } \\
\text { fundamental incompleto }\end{array}$ & 50,1 & 46,5 & 3,4 & 55,4 & 41,1 & 3,5 \\
\hline $\begin{array}{l}\text { Ensino fundamental } \\
\text { completo/ensino médio } \\
\text { incompleto }\end{array}$ & 52,2 & 45,0 & 2,8 & 52,8 & 44,3 & 2,9 \\
\hline $\begin{array}{l}\text { Ensino médio completo/ } \\
\text { ensino superior } \\
\text { incompleto }\end{array}$ & 53,1 & 43,2 & 3,7 & 53,5 & 42,8 & 3,7 \\
\hline Ensino superior completo & 52,3 & 43,7 & 4,0 & 54,3 & 42,1 & 3,6 \\
\hline Não informada & 36,4 & 61,4 & 2,2 & 35,8 & 61,2 & 3,0 \\
\hline \multicolumn{7}{|l|}{ Cor/raça } \\
\hline Branca & 45,4 & 50,6 & 4,0 & 49,6 & 46,3 & 4,1 \\
\hline Preta & 57,3 & 39,8 & 2,9 & 59,3 & 37,4 & 3,3 \\
\hline Amarela & 62,1 & 35,4 & 2,5 & 63,4 & 34,3 & 2,3 \\
\hline Parda & 52,7 & 44,3 & 3,0 & 55,9 & 40,9 & 3,2 \\
\hline Indígena & 41,9 & 45,4 & 12,7 & 55,2 & 41,0 & 3,8 \\
\hline \multicolumn{7}{|l|}{ Idade (anos) } \\
\hline $10-14$ & 16,9 & 80,4 & 2,7 & 17,5 & 80,2 & 2,3 \\
\hline $15-19$ & 34,4 & 63,0 & 2,6 & 34,5 & 63,2 & 2,3 \\
\hline $20-29$ & 55,4 & 40,9 & 3,7 & 54,5 & 41,9 & 3,6 \\
\hline $30-39$ & 62,8 & 33,8 & 3,4 & 64,9 & 31,8 & 3,4 \\
\hline $40-49$ & 63,6 & 33,4 & 3,0 & 66,2 & 30,8 & 3,0 \\
\hline $50-59$ & 65,2 & 31,2 & 3,6 & 69,0 & 27,6 & 3,4 \\
\hline $60+$ & 60,8 & 33,7 & 5,5 & 64,6 & 29,5 & 5,9 \\
\hline Total & 51,2 & 45,4 & 3,4 & 54,4 & 42,1 & 3,5 \\
\hline
\end{tabular}

Fonte: estimativas produzidas pelos próprios autores com base nos dados analisados. 
Tabela 3 - Número médio de filhos tidos (parturição) relatado ao Censo 2010 conforme situação urbana/rural, escolaridade, cor/raça, idade e tipo de respondente, estratificado por região. Regiões Norte e Nordeste - Brasil - 2010

\begin{tabular}{|c|c|c|}
\hline \multirow{2}{*}{ Variável } & \multicolumn{2}{|c|}{ Média de filhos - parturição (IC95\%) } \\
\hline & Norte & Nordeste \\
\hline \multicolumn{3}{|l|}{ Situação urbana/rural } \\
\hline Urbana & $1,95(1,94-1,96)$ & $1,98(1,98-1,99)$ \\
\hline Rural & $2,54(2,53-2,56)$ & $2,65(2,64-2,66)$ \\
\hline \multicolumn{3}{|l|}{ Escolaridade } \\
\hline Analfabeto/ensino primário incompleto & $2,65(2,64-2,66)$ & $2,90(2,89-2,90)$ \\
\hline $\begin{array}{l}\text { Ensino fundamental completo/ ensino médio } \\
\text { incompleto }\end{array}$ & $1,53(1,52-1,54)$ & $1,32(1,31-1,32)$ \\
\hline Ensino médio completo/ ensino superior incompleto & $1,43(1,42-1,44)$ & $1,15(1,14-1,15)$ \\
\hline Ensino superior completo & $1,39(1,38-1,41)$ & $1,26(1,25-1,27)$ \\
\hline Não informada & $0,69(0,64-0,74)$ & $0,53(0,51-0,55)$ \\
\hline \multicolumn{3}{|l|}{ Cor/raça } \\
\hline Branca & $1,90(1,89-1,92)^{*}$ & $2,02(2,01-2,02)^{*}$ \\
\hline Preta & $2,38(2,35-2,41)$ & $2,28(2,27-2,29)$ \\
\hline Amarela & $1,87(1,81-1,92)^{*}$ & $2,04(2,01-2,07)^{*}$ \\
\hline Parda & $2,12(2,11-2,13)$ & $2,19(2,19-2,20)$ \\
\hline Indígena & $2,46(2,40-2,51)$ & $2,52(2,45-2,58)$ \\
\hline \multicolumn{3}{|l|}{ Idade (anos) } \\
\hline $10-14$ & $0,01(0,01-0,01)$ & $0,01(0,01-0,01)$ \\
\hline $15-19$ & $0,23(0,22-0,23)$ & $0,16(0,16-0,17)$ \\
\hline $20-29$ & $1,26(1,25-1,26)$ & $0,97(0,97-0,97)$ \\
\hline $30-39$ & $2,42(2,41-2,43)$ & $2,03(2,03-2,04)$ \\
\hline $40-49$ & $3,23(3,22-3,25)$ & $2,82(2,81-2,83)$ \\
\hline $50-59$ & $4,25(4,22-4,28)$ & $3,91(3,89-3,92)$ \\
\hline $60+$ & $5,84(5,80-5,87)$ & $5,67(5,65-5,68)$ \\
\hline \multicolumn{3}{|l|}{ Tipo de respondente } \\
\hline A própria mulher & $2,69(2,68-2,70)$ & $2,74(2,74-2,75)$ \\
\hline Outro morador do domicílio & $1,39(1,38-1,40)$ & $1,36(1,35-1,36)$ \\
\hline Não morador do domicílio & $2,21(2,16-2,25)$ & $2,37(2,34-2,39)$ \\
\hline Total & $2,08(2,08-2,09)$ & $2,15(2,14-2,15)$ \\
\hline
\end{tabular}

Obs.: Intervalo de confiança (IC) de 95\%.

* Estas médias são estatisticamente diferentes das demais, dentro de cada uma das regiões estudadas ( $p<0,05$, de acordo com teste de heterogeneidade de Wald).

As médias globais para o Norte e o Nordeste são estatisticamente diferentes entre si ( $p<0,05$, conforme o teste de heterogeneidade de Wald).

Fonte: estimativas produzidas pelos próprios autores com base nos dados analisados. 
Tabela 4 - Regressão binomial negativa para estimar a associação entre cor/raça e parturição, estratificada por região e situação urbana/rural, ajustada para idade, escolaridade, total de cômodos do domicílio e número de moradores do domicílio. Regiões Norte e Nordeste - Brasil - 2010

\begin{tabular}{|c|c|c|c|c|}
\hline \multirow{3}{*}{ Variável } & \multicolumn{4}{|c|}{$\begin{array}{l}\text { Coeficiente de regressão para parturição } \\
\text { (intervalo de confiança de } 95 \% \text { ) }\end{array}$} \\
\hline & \multicolumn{2}{|c|}{ Norte } & \multicolumn{2}{|c|}{ Nordeste } \\
\hline & Urbana & Rural & Urbana & Rural \\
\hline \multicolumn{5}{|l|}{ Cor/raça } \\
\hline Branca & $1,00(-)$ & $1,00(-)$ & $1,00(-)$ & $1,00(-)$ \\
\hline Preta & $1,10(1,08-1,12) \uparrow$ & $1,15(1,12-1,19)$ व & $1,04(1,03-1,05)$ ฯ & $1,09(1,07-1,10)$ ฯ \\
\hline Amarela & $1,08(1,04-1,12)$ ฯ & $1,03(0,96-1,11)$ & $1,06(1,04-1,08)$ ฯ & $1,09(1,06-1,12) \uparrow$ \\
\hline Parda & $1,12(1,11-1,14)$ ฯ & $1,18(1,16-1,20)$ ฯ & $1,09(1,08-1,09)$ ฯ & $1,09(1,08-1,10) \pi$ \\
\hline Indígena & $1,39(1,31-1,47)$ ฯ & $1,34(1,29-1,39) \pi$ & $1,18(1,13-1,24)$ ฯ & $1,27(1,22-1,32) \pi$ \\
\hline \multicolumn{5}{|l|}{ Tipo de respondente } \\
\hline A própria mulher & $1,00(-)$ & $1,00(-)$ & $1,00(-)$ & $1,00(-)$ \\
\hline Outro morador do domicílio & $0,98(0,96-0,99)$ बा & $0,99(0,97-1,03)$ & $0,93(0,92-0,93) \rrbracket$ & $0,94(0,92-0,95) \pi$ \\
\hline Não morador do domicílio & $0,97(0,93-1,01)$ & $1,04(0,96-1,12)$ & $0,97(0,95-0,98) \rrbracket$ & $0,98(0,95-1,01)$ \\
\hline \multicolumn{5}{|c|}{ Cor/raça x Tipo de respondente (termo de interação)* } \\
\hline Preta, outro morador & $0,94(0,91-0,98) \pi$ & $0,97(0,92-1,02)$ & $0,95(0,94-0,97)$ ฯ & $0,98(0,95-1,01)$ \\
\hline Preta, não morador & $1,01(0,91-1,12)$ & $1,00(0,86-1,18)$ & $0,92(0,88-0,96)$ ฯ & $0,88(0,83-0,94)$ ๆ \\
\hline Amarela, outro morador & $0,90(0,83-0,97)$ ๆ & $0,94(0,83-1,07)$ & $0,96(0,92-1,00)$ & $0,97(0,92-1,04)$ \\
\hline Amarela, não morador & $0,78(0,59-1,04)$ & $0,98(0,77-1,26)$ & $0,90(0,80-1,01)$ & $1,02(0,88-1,18)$ \\
\hline Parda, outro morador & $0,93(0,91-0,95)$ ฯ & $0,93(0,90-0,96) \pi$ & $0,93(0,92-0,94)$ ฯ & $0,96(0,95-0,98)$ ฯ \\
\hline Parda, não morador & $0,96(0,92-1,01)$ & $0,90(0,83-0,98) \pi$ & $0,90(0,88-0,93)$ ๆ & $0,91(0,88-0,95)$ ฯ \\
\hline Indígena, outro morador & $0,90(0,82-0,99)$ ฯ & $0,93(0,88-0,99) \pi$ & $0,96(0,88-1,04)$ & $0,98(0,91-1,06)$ \\
\hline Indígena, não morador & $0,82(0,63-1,07)$ & $0,84(0,75-0,93) \pi$ & $0,99(0,84-1,17)$ & $0,91(0,78-1,06)$ \\
\hline \multicolumn{5}{|l|}{ Escolaridade } \\
\hline $\begin{array}{l}\text { Analfabeto/ensino primário } \\
\text { incompleto }\end{array}$ & $1,00(-)$ & $1,00(-)$ & $1,00(-)$ & $1,00(-)$ \\
\hline $\begin{array}{l}\text { Ensino primário completo/ } \\
\text { ensino médio incompleto }\end{array}$ & $0,74(0,73-0,75)$ ฯ & $0,75(0,74-0,77)$ ฯ & $0,72(0,71-0,72)$ ฯ & $0,72(0,72-0,73)$ ๆ \\
\hline $\begin{array}{l}\text { Ensino médio completo/ } \\
\text { ensino superior incompleto }\end{array}$ & $0,56(0,56-0,57)$ ฯ & $0,59(0,58-0,61)$ ฯ & $0,53(0,52-0,53) \pi$ & $0,53(0,53-0,54) \pi$ \\
\hline Ensino superior completo & $0,45(0,44-0,45)$ ๆ & $0,53(0,51-0,56) \pi$ & $0,44(0,44-0,45) \rrbracket$ & $0,52(0,50-0,53) \pi$ \\
\hline Não informada & $0,58(0,52-0,63) \pi$ & $0,79(0,67-0,94)$ & $0,59(0,56-0,62)$ ฯ & $0,69(0,63-0,77) \pi$ \\
\hline
\end{tabular}


Tabela 4 - Regressão binomial negativa para estimar a associação entre cor/raça e parturição, estratificada por região e situação urbana/rural, ajustada para idade, escolaridade, total de cômodos do domicílio e número de moradores do domicílio. Regiões Norte e Nordeste - Brasil - 2010 (cont.)

\begin{tabular}{|c|c|c|c|c|}
\hline \multirow{3}{*}{ Variável } & \multicolumn{4}{|c|}{$\begin{array}{l}\text { Coeficiente de regressão para parturição } \\
\text { (intervalo de confiança de } 95 \% \text { ) }\end{array}$} \\
\hline & \multicolumn{2}{|c|}{ Norte } & \multicolumn{2}{|c|}{ Nordeste } \\
\hline & Urbana & Rural & Urbana & Rural \\
\hline \multicolumn{5}{|c|}{ Idade (anos) } \\
\hline $10-14$ & $0,16(0,11-0,22)$ ฯ & $0,11(0,07-0,16)$ ฯ & $0,17(0,13-0,22)$ ฯ & $0,15(0,11-0,19) 9$ \\
\hline $15-19$ & $0,17(0,16-0,18) \pi$ & $0,18(0,17-0,19)$ ฯ & $0,18(0,17-0,18)$ ฯ & $0,18(0,17-0,18)$ \\
\hline $20-29$ & $0,61(0,61-0,62)$ ฯ & $0,60(0,59-0,61)$ ฯ & $0,62(0,61-0,62)$ ฯ & $0,60(0,59-0,60) 9$ \\
\hline $30-39$ & $1,00(-)$ & $1,00(-)$ & $1,00(-)$ & $1,00(-)$ \\
\hline $40-49$ & $1,26(1,24-1,27)$ I & $1,29(1,27-1,32)$ I & $1,28(1,27-1,29) \mathbb{\pi}$ & $1,40(1,38-1,41) 9$ \\
\hline $50-59$ & $1,58(1,56-1,60)$ ฯ & $1,61(1,58-1,64)$ ฯ & $1,72(1,70-1,73) \pi$ & $1,92(1,91-1,94) q$ \\
\hline $60+$ & $2,13(2,10-2,16) \pi$ & $1,91(1,87-1,94)$ I & $2,54(2,52-2,56) \pi$ & $2,50(2,47-2,52) 9$ \\
\hline \multicolumn{5}{|c|}{ Número de cômodos no domicílio } \\
\hline $1+$ & $1,00(1,00-1,00)$ & $1,00(1,00-1,00)$ & $1,00(1,00-1,00) \pi$ & $1,00(1,00-1,00)$ \\
\hline \multicolumn{5}{|c|}{ Número de moradores no domicílio } \\
\hline $1+$ & $1,00(1,00-1,00)$ & $1,00(1,00-1,00)$ & $1,00(1,00-1,00)$ & $1,00(1,00-1,00)$ \\
\hline
\end{tabular}

*A categoria de referência do termo de interação foi constituída por mulheres de cor/raça branca, que responderam diretamente aos recenseadores.

I Associações estatisticamente significativas ( $p<0,05$ ), conforme o teste de heterogeneidade de Wald. Apenas coeficientes (razões de incidência) para a contagem de filhos tidos são apresentados na tabela.

Fonte: estimativas produzidas pelos próprios autores com base nos dados analisados. 
Gráfico 1 - Médias de parturição (e seus intervalos de confiança de 95\%) conforme cor/raça e tipo de respondente, ajustadas para idade, escolaridade, total de cômodos do domicílio e número de moradores do domicílio. Região Nordeste - Brasil - 2010
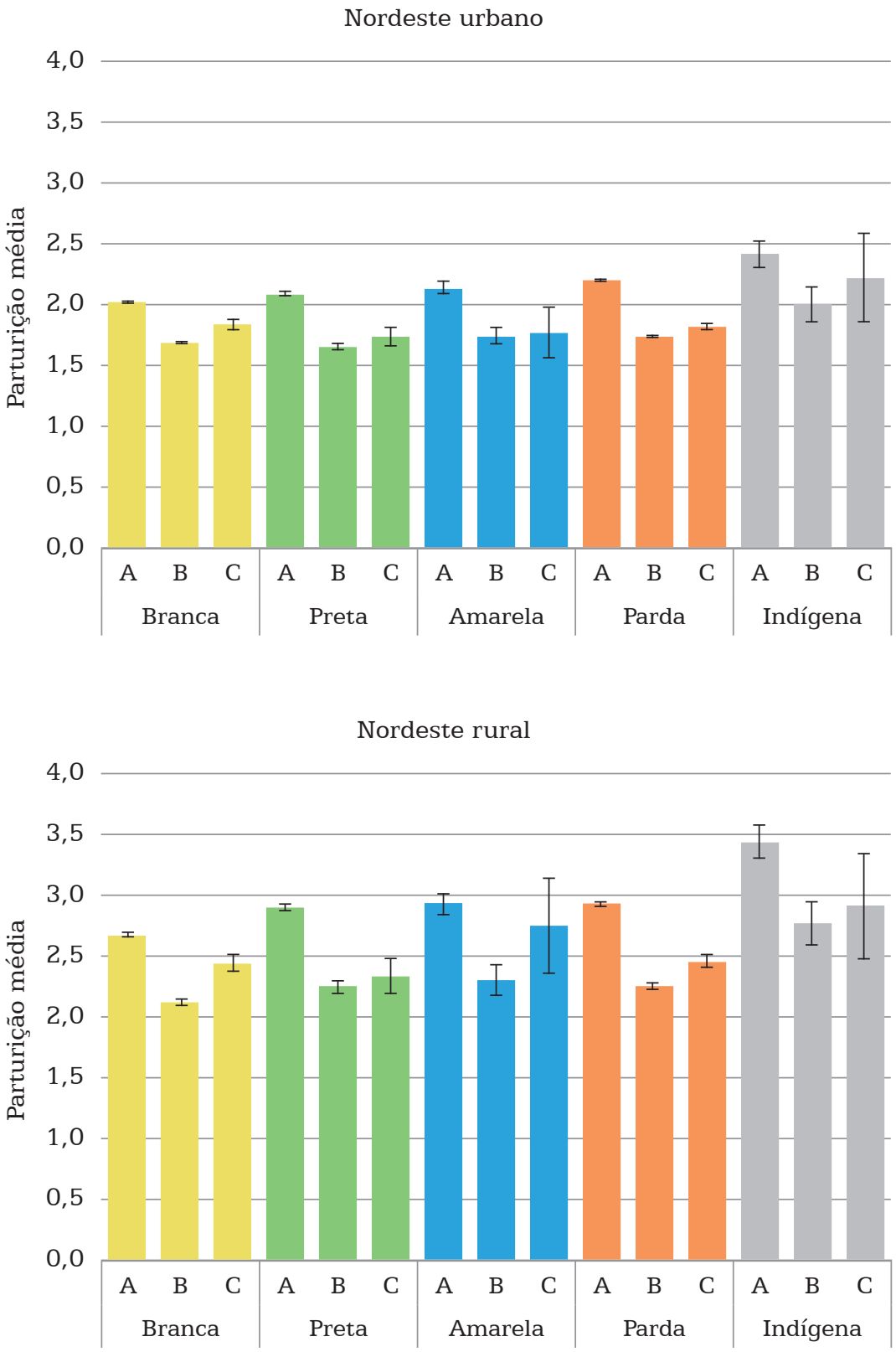

Obs.: A = informação fornecida pela própria mulher, $\mathrm{B}=$ informação provida por outro morador, C = informação dada por não morador.

Fonte: estimativas produzidas pelos próprios autores com base nos dados analisados. 
Gráfico 2 - Médias de parturição (e seus intervalos de confiança de 95\%) conforme cor/raça e tipo de respondente, ajustadas para idade, escolaridade, total de cômodos do domicílio e número de moradores do domicílio. Região Norte - Brasil - 2010
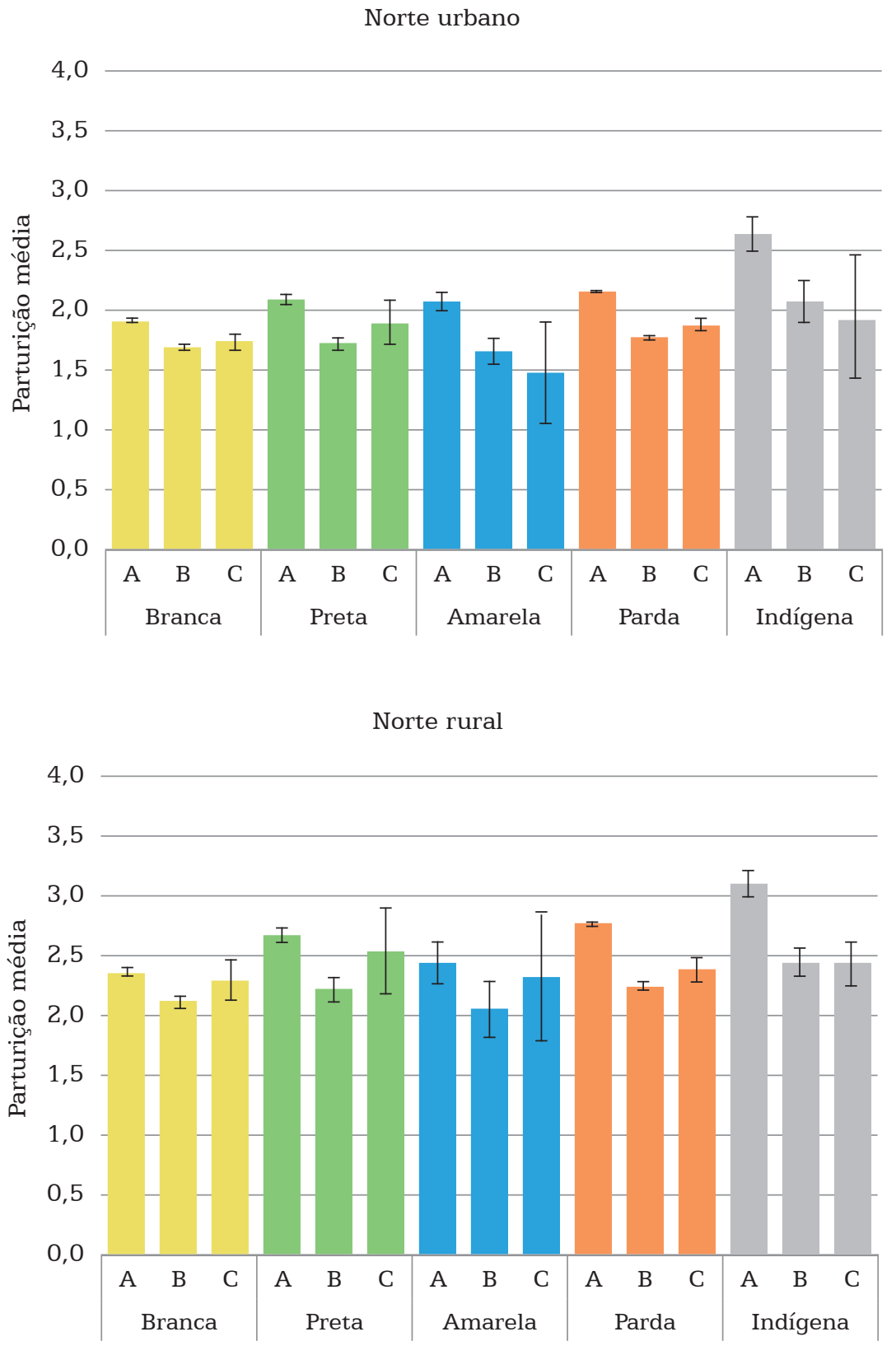

Obs.: $\mathrm{A}=$ informação fornecida pela própria pessoa; $\mathrm{B}=$ informação provida por outro morador; $\mathrm{C}=$ informação dada por não morador.

Fonte: estimativas produzidas pelos próprios autores com base nos dados analisados. 


\section{Interpretação e implicações dos achados}

Em meio à ainda limitada, mas crescente, literatura sobre demografia dos povos indígenas no Brasil baseada em dados censitários (Azevedo, 2011; IBGE, 2005, 2012; Pagliaro, Azevedo G Santos, 2005; Perz et al., 2008; Santos G Teixeira, 2011), pouca atenção tem sido dada ao fato de que sociedades culturalmente diferenciadas podem apresentar características, incluindo filiação linguística, que potencialmente afetam os padrões de resposta dados aos recenseadores. Os resultados deste estudo demonstraram que as mulheres indígenas, especialmente as da região Norte, responderam diretamente aos entrevistadores do censo em uma percentagem expressivamente menor do que aquelas de outras categorias de cor/raça. Um achado que merece destaque foi que 12,7\% das mulheres indígenas do Norte tiveram suas informações fornecidas ao censo por um não morador de seus domicílios, frequência bastante acima daquela observada para outros grupos de cor/raça da mesma região, a qual variou entre 2,5\% (amarelas) e 4,0\% (brancas). É igualmente revelador que, no caso das mulheres do Nordeste, tais diferenças não foram detectadas.

Observou-se também que as diferenças mais expressivas na parturição média estão relacionadas ao tipo de respondente. Quando a contagem de filhos não é informada diretamente pela mãe, mas por respondentes proxy (tanto um morador quanto um não morador do domicílio), os valores médios de parturição tendem a ser consideravelmente mais baixos. Esse não é apenas o caso das mulheres indígenas, mas também o dos demais grupos de cor/raça nas duas regiões abordadas, tanto em áreas urbanas quanto rurais. O maior percentual de mulheres indígenas cujas informações foram providas por um não morador no Norte $(12,7 \%)$ sugeriu que a relação entre parturição e tipo de respondente pode ser diferente nas duas regiões investigadas. Entretanto, após controlar para um conjunto de covariáveis no contexto de modelos de regressão, constatou-se que a subestimação da parturição de mulheres indígenas foi semelhante no Norte e no Nordeste, tanto entre outros moradores quanto entre não moradores dos domicílios. Deve-se salientar, contudo, que as comparações de parturição, levando em consideração situação urbana/rural e tipo de respondente, indicam que a subestimação da parturição foi particularmente pronunciada entre as indígenas do Norte rural (16\% menor em relação às mulheres brancas que responderam diretamente aos recenseadores).

Independentemente da cor/raça, a subestimação da parturição possivelmente deriva do fato de que respondentes proxynão estão em condições de informar precisamente o número de filhos, o que também se aplicaria a outros dados relativos à história reprodutiva das mulheres. Por exemplo, respondentes proxy podem desconhecer filhos que já vieram a falecer ou que não coabitam o mesmo domicílio da mãe. Quando a informação não é fornecida diretamente pela mulher, tais casos 
podem ser omitidos da contagem. O fato de que os povos indígenas no Brasil apresentam maiores taxas de mortalidade infantil pode exercer um impacto adicional sobre a contagem de filhos informada por respondentes proxy, na medida em que estes tendem a desconhecer suas histórias reprodutivas (Cardoso, Santos G Coimbra, 2005; IBGE, 2005). A combinação dessas duas dimensões - menores frequências de mulheres indígenas relatando a quantidade de filhos diretamente aos entrevistadores e tendência a fornecer dados menos precisos por parte dos respondentes proxy - culminou em um efeito sinérgico, o qual pode contribuir para a compreensão da subestimação ainda mais acentuada da parturição das mulheres indígenas, especialmente na região Norte.

Quais fatores poderiam explicar a menor frequência de respostas dadas diretamente aos entrevistadores entre as mulheres indígenas da região Norte? É provável que aspectos socioculturais exerçam um papel central nesse caso. Relativamente a outras regiões brasileiras, as sociedades indígenas que vivem no Norte puderam preservar mais não somente as suas línguas nativas, mas também seus territórios tradicionais (Hemming, 1987; Ricardo G Ricardo, 2011). A razão para tais acontecimentos é histórica. A região Norte foi a última a experimentar colonização em larga escala, particularmente dos anos 1960 em diante. Em alguma medida, apesar das altas taxas de mortalidade e violência, no período mais recente, movimentos indígenas têm conseguido assegurar alguns direitos às sociedades indígenas do Norte, não se observando o mesmo para outras regiões do país.

A colonização do Nordeste por não indígenas teve início no século XVI, o que significa que as sociedades indígenas nessa área foram as primeiras a experimentar os impactos devastadores da chegada dos europeus, que acarretaram redução massiva das populações, perda de territórios e de línguas (Hemming, 1987; Oliveira-Filho, 2011; Ricardo G Ricardo, 2011). Dados do Censo Demográfico 2010 demonstram como algumas características culturais e socioeconômicas das sociedades indígenas atuais refletem os efeitos de longa duração de quinhentos anos de colonização por não indígenas. Enquanto 26,2\% dos declarados indígenas com 5 anos de idade ou mais na região Norte não falavam português, tal estimativa foi de apenas 3,2\% no Nordeste (IBGE, 2012). Tendo esse complexo cenário sociopolítico e histórico como pano de fundo, o fato de que o censo é conduzido em português pode influenciar padrões de coleta de dados em algumas circunstâncias, tais como aquelas apresentadas por determinados grupos indígenas, entre os quais parte ou a totalidade da população não utiliza o português em sua comunicação cotidiana.

No âmbito deste estudo, a variável relativa ao tipo de respondente foi central. Um aspecto relevante diz respeito à identidade dos não moradores que, tal como vimos para a região Norte em particular, exerceu um papel importante no fornecimento de informações das mulheres indígenas. De acordo com o IBGE, principalmente em centros urbanos do Brasil, o não morador é frequentemente uma trabalhadora doméstica, 
que está no domicílio no momento da visita do entrevistador (IBGE, 2013). No caso dos povos indígenas, é improvável que esse também seja o caso, de modo que não moradores geralmente incluem profissionais da saúde ou professores que trabalham e vivem nas comunidades e que também possuem ancestralidade indígena, na maior parte dos casos. Outras pesquisas de abrangência nacional, tal como o Primeiro Inquérito Nacional de Saúde e Nutrição Indígena, realizado em 2008 (Coimbra et al., 2013), documentaram o importante papel exercido por esses profissionais no que se refere às dinâmicas e ao estabelecimento de vínculos com as comunidades, incluindo sua contribuição como intérpretes durante a realização das entrevistas. Ainda que residam e trabalhem nesses locais e estejam, portanto, familiarizados com características culturais e, eventualmente, com a língua nativa, profissionais da saúde ou professores não estão necessariamente a par da história reprodutiva das mulheres a ponto de fornecer informações tão precisas quanto elas próprias.

Embora este capítulo tenha enfatizado um conjunto específico de variáveis relacionadas com a parturição, os aspectos levantados têm implicações para uma ampla sorte de outras condições de interesse. Da mesma forma que a parturição de mulheres indígenas pode ser afetada pelo tipo de respondente e pela frequência com que cada um deles provê informação aos recenseadores, as estimativas de diversos outros parâmetros demográficos, desde coeficientes de mortalidade a condições socioeconômicas, podem ser igualmente influenciadas por processos semelhantes. Em íntima relação com a parturição, as estimativas de fecundidade constituem um bom exemplo adicional. Análises baseadas no Censo Demográfico 2010 (IBGE, 2010b) mostraram altas taxas de fecundidade total (TFT) para mulheres indígenas: 2,90 no Sudeste, 3,01 no Nordeste, 3,74 no Sul, 4,30 no Centro-Oeste e 4,92 no Norte, com uma estimativa global para o país de 3,88 (IBGE, 2012). Tal como tem sido sugerido em diversas outras investigações voltadas para a caracterização dos padrões de fecundidade no Brasil (Carvalho G Brito, 2005; Goldani, 2009; Potter et al., 2010), essas diferenças inter-regionais na fecundidade indígena possivelmente também derivam de uma complexa interação entre fatores comportamentais e sociodemográficos, incluindo escolaridade, participação da mulher no mercado de trabalho e acesso a métodos contraceptivos, entre outros. Pode-se argumentar que, se o tipo de respondente fosse levado em consideração, as TFTs para mulheres indígenas do Norte seriam ainda mais altas, afetando as comparações inter-regionais para esse segmento da população. Em uma dimensão mais ampla, as análises dos padrões demográficos de populações brasileiras (indígenas e não indígenas), incluindo os importantes tópicos da transição nos níveis de mortalidade e fecundidade, deveriam levar em consideração que as estimativas são potencialmente afetadas por fatores não estritamente demográficos. 


\section{Considerações finais}

Análises das características demográficas dos povos indígenas baseadas em dados censitários têm se tornado cada vez mais importantes nos debates sobre saúde, educação e outras desigualdades socioeconômicas em todo o mundo (Axelsson G Sköld, 2011; Axelsson et., 2011; Kertzer G Arel, 2002; Morning, 2008; Paho, 2006; UN, 2009). Contudo, tal como Axelsson e Sköld (2011: 5) têm argumentado em relação às limitações dos inquéritos de larga escala não especificamente planejados para coletar dados em meio a povos indígenas, "censos conduzidos por agências externas, dados administrativos e de inquéritos são frequentemente imprecisos, quando se trata de representar as estruturas sociais indígenas". Ao mesmo tempo que é fundamental expandir a coleta de dados demográficos de populações indígenas, não se pode negligenciar o fato de que a qualidade dos dados pode ser afetada por condições específicas nas quais a coleta transcorre. O estudo de caso de populações indígenas do Brasil aqui apresentado proporciona evidência contundente de que os padrões de resposta de mulheres indígenas aos entrevistadores do censo podem influenciar a estimação de parâmetros demográficos. Esse fenômeno também foi observado para mulheres não indígenas, porém, não com a mesma intensidade.

Algumas iniciativas recentes na América Latina, tal como a inclusão de perguntas sobre línguas indígenas nos questionários dos censos, são avanços bem-vindos que podem contribuir para melhorar a caracterização da demografia indígena (Del Popolo, 2008; Del Popolo et al., 2011; Frutos, Sanabria G Servin, 2004). Enquanto rotinas específicas para coleta de dados em populações culturalmente diferenciadas, tais como os povos indígenas, não forem implementadas de modo mais amplo, tanto na América Latina quanto em outras regiões do mundo, mais atenção deve ser dada aos diferenciais demográficos que podem resultar dos processos de coleta de dados. É desnecessário enfatizar que tais diferenciais podem influenciar a definição e a implementação de políticas públicas de saúde destinadas ao combate da marginalização socioeconômica que caracteriza todos os povos indígenas ao redor do mundo. A implementação de alternativas metodológicas nos censos brasileiros, incluindo a seleção e o treinamento de entrevistadores fluentes nas línguas nativas e familiarizados com suas respectivas culturas, pode ser útil na melhoria da qualidade da coleta de dados. Tendo em vista que os diferenciais de parturição, conforme o tipo de respondente, foram observados em todos os grupos de cor/raça, futuras investigações sobre estimativas desse parâmetro e os fatores que o afetam devem ser realizadas em todas regiões do país. 
* Este capítulo é uma tradução, com adaptações, de artigo previamente publicado por Santos e colaboradores (2015). Foi reproduzido aqui com a devida autorização.

1 Os dados dos censos nacionais estão disponibilizados em páginas eletrônicas de domínio público e não houve necessidade de aprovação prévia do protocolo do presente estudo por um comitê de ética, de acordo com a resolução de ética para pesquisa com seres humanos no Brasil utilizando dados secundários (Conselho Nacional de Saúde, resolução n. 466/2012).

\section{Referências}

AXELSSON, P. G SKÖLD, P. Indigenous peoples and demography. In: AXELSSON, P. G SKÖLD, P. (Eds.). Indigenous Peoples and Demography: the complex relation between identity and statistics. New York: Berghahn Books, 2011.

AXELSSON, P. et al. Epilogue: from indigenous demographics to an indigenous demography. In: AXELSSON, P. G SKÖLD, P. (Eds.). Indigenous Peoples and Demography: the complex relation between identity and statistics. New York: Berghahn Books, 2011.

AZEVEDO, M. M. O Censo 2010 e os povos indígenas. In: RICARDO, C. A. G RICARDO, F. (Orgs.). Povos Indígenas do Brasil 2006/2010. São Paulo: Instituto Socioambiental, 2011.

CARDOSO, A. M.; SANTOS, R. V. G COIMBRA, C. E. A. Mortalidade infantil segundo raça/cor no Brasil: o que dizem os sistemas nacionais de informação? Cadernos de Saúde Pública, 21(5): 1.602-1.608, 2005.

CARVAlHO, J. A. M. G BRITO, F. A demografia brasileira e o declínio da fecundidade no Brasil: contribuições, equívocos e silêncios. Revista Brasileira de Estudos Populacionais, 22(2): 351-369, 2005.

COIMBRA JR., C. E. A. G SANTOS, R. V. Emerging health needs and epidemiologic research in indigenous peoples in Brazil. In: SALZANO, F. M. G HURTADO, M. (Eds.). Lost Paradise and the Ethics of Research and Publication. Oxford: Oxford University Press, 2004.

COIMBRA JR., C. E. et al. The first national survey of indigenous people's health and nutrition in Brazil: rationale, methodology, and overview of results. BMC Public Health, 13: 52, 2013. Disponível em: <www.biomedcentral.com/1471-2458/13/52> . Acesso em: 10 set. 2014.

DEL POPOLO, F. Los Pueblos Indígenas y Afrodescendientes en las Fuentes de Datos: experiencias en América Latina. Santiago: Comisión Económica para América Latina y el Caribe, 2008. 
DEL POPOLO, F. et al. El Derecho de la Información de los Pueblos Indígenas y Afrodescendientes: obligaciones urgentes en América Latina. Santiago: Centro Latinoamericano y Caribeño de Demografia, 2011.

FRUTOS, N. D.; SANABRIA, C. L. F. G SERVIN, Z. C. S. Atlas de las Comunidades Indígenas en el Paraguay. Assunción: Dirección General de Estadística, Encuestas y Censos, 2004.

GOLDANI, A. M. What Will Happen to Brazilian Fertility? New York: United Nations, 2009.

GONÇALVES, J. M. M. IBGE: um retrato histórico. Rio de Janeiro: IBGE, 1995.

HEMMING, J. The Amazon Frontier: the defeat of the Brazilian indians. London: MacMillan Press, 1987.

INCAYAWAR, M. G MALDONADO-BOUCHARD, S. The forsaken mental health of the indigenous peoples: a moral case of outrageous exclusion in Latin America. BMC International Health and Human Rights, 9: 27, 2009. Disponível em: <www.biomedcentral.com/1472698X/9/27>. Acesso em: 17 set. 2014.

INSTITUTO BRASILEIRO DE GEOGRAFIA E ESTATÍSTICA (IBGE). Tendências Demográficas: uma análise dos indígenas com base nos resultados da amostra dos Censos Demográficos 1991 e 2000. Rio de Janeiro: IBGE, 2005.

INSTITUTO BRASILEIRO DE GEOGRAFIA E ESTATÍSTICA (IBGE). Estatísticas do Século $X X$. Rio de Janeiro: IBGE, 2006.

INSTITUTO BRASILEIRO DE GEOGRAFIA E ESTATÍSTICA (IBGE). Censo Demográfico 2010: manual do recenseador. Rio de Janeiro: IBGE, 2010a.

INSTITUTO BRASILEIRO DE GEOGRAFIA E ESTATístiCA (IBGE). Censo Demográfico 2010: nupcialidade, fecundidade e migração - resultados da amostra. Rio de Janeiro: IBGE, 2010b.

INSTITUTO BRASILEIRO DE GEOGRAFIA E ESTATÍSTICA (IBGE). Censo Demográfico 2010: características gerais dos indígenas - resultados do universo. Rio de Janeiro: IBGE, 2012.

INSTITUTO BRASILEIRO DE GEOGRAFIA E ESTATÍstiCA (IBGE). Metodologia do Censo Demográfico 2010. Rio de Janeiro: IBGE, 2013.

KERTZER, D. G AREL, D. Census and Identity: the politics of race, ethnicy and language in national censuses. Cambridge: Cambridge University Press, 2002.

McSWEENEY, K. G ARPS, S. A "demographic turnaround": the rapid growth of the indigenous populations in lowland Latin America. Latin American Research Review, 40(1): 3-29, 2005.

MONTENEGRO, R. A. G STEPHENS, C. Indigenous health in Latin America and the Caribbean. The Lancet, 367(9.525): 1.859-1.869, 2006.

MORNING, A. Ethnic classification in global perspective: a cross-national survey of the 2000 census round. Population Research and Policy Review, 27(2): 239-272, 2008. 
NOBLES, M. Shades of Citizenship: race and the census in modern politics. Stanford: Stanford University Press, 2000.

OLIVEIRA-FILHO, J. P. A Presença Indígena no Nordeste: processos de territorialização, modos de reconhecimento e regimes de memória. Rio de Janeiro: Contra Capa, 2011.

PAGLIARO, H.; AZEVEDO, M. M. G SANTOS, R. V. Demografia dos Povos Indígenas no Brasil. Rio de Janeiro: Editora Fiocruz, Abep, 2005.

PAN AMERICAN HEALTH ORGANIZATION (PAHO). Health of the Indigenous Peoples in the Americas. Washington: Pan American Health Organization, 2006.

PERZ, S. G.; WARREN, J. G KENNEDY, D. P. Contributions of racial-ethnic reclassification and demographic processes to indigenous population resurgence: the case of Brazil. Latin American Research Review, 43(2): 7-33, 2008.

POTTER, J. E. et al. Mapping the timing, pace, and scale of the fertility transition in Brazil. Population and Development Review, 36(2): 283-307, 2010.

RICARDO, C. A. G RICARDO, F. Povos Indígenas no Brasil 2006/2010. São Paulo: Instituto Socioambiental, 2011.

SANTOS, R. V. G TEIXEIRA, P. O "indígena" que emerge do Censo Demográfico de 2010. Cadernos de Saúde Pública, 27(6): 1.048, 2011.

SANTOS, R. V. et al. Parity of indigenous and non-indigenous women in Brazil: does the reported number of children born depend upon who answers National Census questions? Plos One, 10(4), 2015. Disponível em: < https://doi.org/10.1371/journal.pone.0123826>. Acesso em: 10 mar. 2019.

UNITED NATIONS (UN). State of the World's Indigenous Peoples. New York: United Nations, 2009. 


\section{"Você Se Considera Indígena?": características da população residente em terras indígenas investigadas pelo Censo Demográfico de 2010*}

Gerson Luiz Marinho

Ricardo Ventura Santos

Alessandra Traldi Simoni

O primeiro recenseamento nacional realizado no Brasil aconteceu em 1872 e, desde então, vem ocorrendo aproximadamente a cada dez anos, ainda que não tenham sido realizados em alguns períodos, como nas décadas de 1880, 1910 e 1930 (Petruccelli G Saboia, 2013; Oliveira, 2012; Santos et al., 2019). Ao longo do último século e meio, perguntas sobre a composição de "cor ou raça" da população brasileira foram incluídas na maior parte dos censos, observando-se, contudo, variações importantes na forma de coleta e nas categorias do quesito, o que reflete contextos históricos e sociopolíticos particulares (Osorio, 2003; Petruccelli G Saboia, 2013; Santos et al., 2019).

Nota-se que, desde a década de 1990, tem ocorrido um expressivo aumento na captação de dados relativos às populações indígenas nos censos realizados em diversos países da América Latina (Del Popolo et al., 2011; Loveman, 2014; Pagliaro et al., 2005; Santos et al., 2019). Esse cenário se associa a transformações históricas e sociopolíticas que, influenciadas por debates e acordos internacionais, têm resultado na valorização das identidades indígenas no contexto dos processos de revisão dos textos constitucionais de diversos países na região (Fajardo, 2009; UN, 2009; Del Popolo, 2008; Del Popolo et al., 2011; Loveman, 2014; Oliveira, 2016; Santos et al., 2019).

Na história recente, foram conduzidos três censos nacionais no Brasil (1991, 2000 e 2010) pelo Instituto Brasileiro de Geografia e Estatística (IBGE) nos quais houve captação de dados específicos sobre a população indígena (IBGE, 2012; Santos et al., 2019). Em 1991, inclui-se a categoria "indígena" como mais uma opção de resposta para a pergunta em relação à "cor ou raça", o que se manteve em 2000 e 2010. Em particular no Censo mais recente (2010), além de a pergunta ter sido incorporada também no chamado questionário básico, aplicado em todos os domicílios do país, houve uma expansão na captação de dados acerca da população indígenas, incluindo dimensões ligadas à moradia, saneamento, pertencimento étnico e línguas faladas nos domicílios (Azevedo, 2011; IBGE, 2005, 2012; Pereira, 2016; Santos et al., 2019). Foram também registrados avanços metodológicos, como 
a compatibilização dos setores censitários com os limites das terras indígenas (TIs), que passaram a ser mais claramente definidas e identificadas na base territorial utilizada no levantamento censitário (IBGE, 2012; Pereira, 2016).

Outra inovação do Censo 2010, foco da análise deste capítulo, foi a aplicação da pergunta "Você se considera indígena?"1 para as pessoas residentes nas TIs que não se identificaram como "indígenas" na pergunta sobre "cor ou raça", ou seja, que se declararam em uma das demais categorias, quais sejam, "branca", "preta", "amarela" ou "parda" (IBGE, 2012; Pereira, 2016). Segundo o IBGE, a questão visou a captar informações sobre: "pessoa, residente em terras indígenas, que não se declarou indígena, na investigação sobre cor ou raça, mas se considerava indígena, de acordo com as tradições, costumes, cultura, antepassados etc." (IBGE, 2012: 41). Essa estratégia metodológica adveio de observações realizadas em testes-piloto para o Censo 2010, nos quais se observou que, em algumas TIs investigadas, uma parcela expressiva dos entrevistados não se declarava indígena na pergunta sobre cor ou raça (IBGE, 2012; Pereira, 2016; Santos et al., 2019). Em 2010, foi registrado um total de 817.963 indígenas no quesito "cor ou raça" (438.429 em TIs e 379.534 fora delas) e 78.954 indígenas a partir das repostas para a pergunta "se considera", totalizando 896.917 (IBGE, 2012).

O objetivo deste capítulo é analisar a distribuição e o perfil da população que se considerou indígena no Censo 2010, comparando-o com o da população declarada indígena segundo a pergunta sobre "cor ou raça". Como veremos, um importante ponto que emerge das análises diz respeito às significativas variações nos contingentes de pessoas que se consideraram indígenas entre as regiões e também segundo situação urbana e rural, o que levanta questões sobre os fatores que podem ter influenciado a captação dos dados censitários para a população indígena.

\section{Fontes de dados e procedimentos analíticos}

\section{Fontes de dados}

Os dados aqui analisados se referem à totalidade de pessoas residentes nas TIs existentes no Brasil ( $\mathrm{N}=501)$, identificadas através do questionário básico (universo) do Censo 2010 (IBGE, 2012), e foram obtidos nos sites do Banco Multidimensional de Estatísticas (BME) (<www.bme.ibge.gov.br >) e do Sistema de Recuperação Automática (Sidra) (<www.sidra.ibge.gov.br $>$ ). Ambas as ferramentas disponibilizam dados de pesquisas realizadas pelo IBGE, inclusive aqueles derivados dos censos demográficos decenais.

Com vistas a caracterizar mais detalhadamente os contingentes populacionais residentes nas TIs, os resultados derivados das perguntas de "cor ou raça" e do quesito "se considera" foram comparados com contagens compiladas e publicadas 
entre 2005 a 2015 pelo Instituto Socioambiental (ISA) (<www.socioambiental.org/ pt-br/o-isa/websites/de-olho-nas-terras-indigenas-no-brasil >). Essa organização não governamental sistematiza, desde a década de 1980, informações obtidas em campo por pesquisadores (em geral antropólogos) e por instituições envolvidas em atividades de execução da política indigenista no Brasil, incluindo a Fundação Nacional do Índio (Funai), a Fundação Nacional de Saúde (Funasa) e a Secretaria Especial de Saúde Indígena (Sesai). Os dados do Censo 2010 foram comparados com os temporalmente mais próximos de 2010 disponibilizados pelo ISA.

\section{Dados investigados}

A população incluída no estudo corresponde ao total de residentes nas 501 TIs investigadas pelo universo do Censo 2010 ( $\mathrm{N}=567.582$ pessoas), segundo duas variáveis: 1) pessoas classificadas como "indígenas" na pergunta sobre "cor ou raça"; 2) residentes em TIs classificados como "brancos, pretos, amarelos e pardos" na pergunta sobre "cor ou raça" (ou seja, os elegíveis para responder ao quesito "Você se considera indígena?").

Com o propósito de caracterizar aspectos demográficos, socioeconômicos e distribuição geográfica da população residente nas TIs, os resultados referentes à população elegível para responder ao quesito "se considera" foram apresentados segundo três categorias ("sim", "não" e "ignorado").

Foi também investigado o padrão de respostas acerca de "etnia ou povo" para as pessoas que se classificaram como "indígenas" na pergunta sobre "cor ou raça" e para as que responderam positivamente à pergunta "se considera indígena". Especificamente, foram tabuladas as frequências de respostas "não sabe" e "sem declaração" (ou seja, quesito não respondido pelos entrevistados).

\section{Análise dos dados}

Os moradores das TIs, distribuídos nas categorias: 1) "cor ou raça indígena", 2) "se considera indígena", 3) "não se considera indígena" e 4) "ignorado" (quanto a "se considerar indígena"), foram caracterizados quanto à localização do domicílio em área urbana ou rural e distribuição geográfica segundo regiões. Os grupos populacionais foram descritos de acordo com os seguintes aspectos individuais: sexo, idade, alfabetização, rendimento mensal total em faixas de salários mínimos (SMs), e se as informações ao entrevistador foram providas pela própria pessoa recenseada ou por outro informante. Foi também analisada a distribuição segundo "cor ou raça" (nas categorias "branca", "preta", "amarela" e "parda") daqueles que "se consideraram indígenas". 
Seguindo definição utilizada no Censo 2010, foram consideradas "alfabetizadas pessoas maiores de cinco anos de idade capazes de ler e escrever pelo menos um bilhete simples no idioma que conhece" (IBGE, 2012: 70). O rendimento nominal mensal foi perguntado para pessoas de 10 anos ou mais de idade e definido como "a soma do rendimento nominal mensal de trabalho com o proveniente de outras fontes, expressa em classes de valores em salários mínimos" (equivalente a $\mathrm{R} \$$ 510,00 reais) (IBGE, 2012: 46-47).

Devido aos critérios de confidencialidade adotados pelo IBGE, os resultados gerados pelo BME são somente disponibilizados para as TIs com pelo menos 800 residentes (valor relativo ao tamanho do menor município existente em 2010). Por essa razão, os dados do BME incluíram apenas 146 TIs (29,0\% do total). Complementarmente, foram acessados os dados relativos ao total de residentes pelo Sidra, o que alcançou 478 TIs, pois 23 não tiveram os dados disponibilizados por motivos de confidencialidade e quatro não estavam listadas).

Cabe indicar que o IBGE considerou as TIs nas seguintes situações jurídicas, segundo cadastro da Funai: "declarada", "homologada", "regularizada" e "em processo de aquisição como reserva indígena", totalizando 505 (IBGE, 2012).

\section{Detalhamento dos principais resultados}

De acordo com o Censo 2010, 567.582 pessoas residiam em domicílios localizados em TIs, das quais 438.429 (77,2\%) "se declararam" como "indígenas" no quesito "cor ou raça". Seguindo a metodologia censitária, os 129.153 classificados nas demais categorias ("branca", "preta", "amarela" ou "parda") foram questionados se "se consideravam indígenas". Desses, $78.954(61,1 \%)$ responderam "sim", 30.691 (23,8\%) "não" e 19.508 (15,1\%) tiveram registro "ignorado". Desse modo, para os residentes em TIs, ao se somarem as quantidades de "indígenas" segundo o critério de "cor ou raça" (438.429 pessoas) e "se considera" (78.954), que alcançou 517.383 pessoas, a proporção de indígenas no quesito "se considera" foi de 15,3\%.

Na Tabela 1 é apresentada uma descrição geral dos que se declararam indígenas na pergunta sobre "cor ou raça" e nas opções da pergunta "se considera", segundo situação urbana e rural dos domicílios localizados em TIs. Já que as porcentagens se referem às colunas, as interpretações desses resultados precisam levar em conta que aproximadamente metade das pessoas que se declararam "indígenas" na pergunta sobre "cor ou raça" residia na região Norte, o que impacta diretamente a composição etária, alfabetização, distribuição de renda etc. Apesar da influência do fator regional nos perfis observados, nota-se que as distribuições de respostas para os quesitos "cor ou raça indígena" e "se considera sim" se mostraram mais próximas entre si, e as demais categorias (ou seja, "não" e "ignorado") apresentaram distribuições comparativamente menos semelhantes. 
A seguir são descritas as características sociodemográficas somente da população elegível para responder ao quesito "se considera" ( $N=129.153$ pessoas), com distribuições relativas ao total nas linhas. Assim procedendo, emergem importantes diferenças, tanto para a situação urbana como a rural (Tabela 2).

Em áreas urbanas, destacam-se os seguintes achados: 1) as porcentagens na coluna "se considera sim", com poucas exceções, estão abaixo de $30 \%$, evidenciando que as respostas mais frequentes foram "não" e "ignorado"; 2) há marcantes diferenças entre as regiões, com acentuadas porcentagens de "ignorado" (> 60\%) no Norte, Sudeste e Sul, contrastando com o predomínio de "não" no Nordeste e "sim" no Centro-Oeste); 3) para as variáveis sexo e idade, apesar de algumas diferenças, as distribuições de porcentagens se mostraram relativamente próximas entre as categorias de respostas; 4) os indivíduos não alfabetizados apresentaram uma maior porcentagem de resposta "se considera não" e foi mais expressiva a porcentagem de "se considera ignorado" entre os alfabetizados; 5) quanto à renda per capita, as pessoas nas categorias "não tem" e "até 1 SM" apresentaram maiores porcentagens de resposta "se considera sim" que os de maior renda ("mais de 1 e até 3 SM"; "mais de 3 SM, respectivamente) que, por sua vez, tiveram quase metade das respostas "ignoradas" (44,4\% e 46,8\%, respectivamente); 6) para as demais variáveis (informante e "cor ou raça" declarada), nota-se que "não morador" e pessoas classificadas como "pretas" tenderam a apresentar maiores porcentagens de respostas "se considera ignorado" (33,9\% e 39,5\%, respectivamente).

Quanto à situação rural, os padrões de resposta foram distintos dos descritos para os domicílios urbanos, com destaque para as elevadas frequências na coluna "se considera sim" para todas as variáveis (acima de 60\% em todos os casos). Ao se compararem as distribuições de respostas ("se considera sim", "não" e "ignorado"), segundo as variáveis analisadas, as diferenças mais expressivas são observadas entre as regiões. Nesse caso, as porcentagens de "se considera sim" variaram de 60,2\% (Sul) a 94,4\% (Sudeste), sendo que no Sul foi também registrada a mais elevada proporção de "ignorado" (27,4\%).

A resposta afirmativa para a pergunta "se considera" teve um impacto ao mesmo tempo expressivo e diferenciado, ao se compararem as situações urbana e rural nas várias regiões (Tabela 3). Conforme anteriormente indicado, do total de "indígenas" residentes em TIs, a partir dos dois critérios ("cor ou raça" e "se considera"), a proporção segundo "se considera indígena" alcançou 15,3\%. Por sua vez, do total de indígenas residentes em TIs localizadas em áreas urbanas, 37,1\% derivaram do quesito "se considera". Ao se desagregarem as análises por região, observa-se que a resposta "se considera sim" foi responsável por um quarto ou mais do total de indígenas residentes em TI urbanas no Sul (27,0\%), Centro-Oeste $(38,6 \%)$ e Nordeste $(43,0 \%)$. Na situação rural, a porcentagem para o país como um todo foi expressivamente mais baixa $(14,1 \%)$, variando de $7,7 \%$ (Sudeste) a $18,2 \%$ (Nordeste). 
A Figura 1 apresenta a composição etária dos indígenas residentes em TI em situação urbana e rural, respectivamente, segundo as respostas para as perguntas sobre "cor ou raça" e "se considera". Em ambas categorias, a população residente em área urbana é composta majoritariamente por adultos jovens, enquanto a rural se caracteriza por ter uma maior parcela pertencente às faixas etárias mais jovens (< 10 anos de idade). Observa-se também que, para a situação rural, o perfil etário das pessoas que se consideraram indígenas é composto por menor proporção de jovens (< 20 anos) e maior de adultos (20-60 anos) se comparado aos indivíduos que se declararam indígenas na pergunta sobre "cor ou raça".

Tanto para os que se declararam "indígenas" na pergunta sobre "cor ou raça" como para os que se consideraram "indígenas", as frequências de respostas "não sabe" sua etnia ou povo foram extremante baixas (<2\%) em todas as regiões, tanto em área urbana como rural (resultados não apresentados nas tabelas ou figura). Quanto à resposta "sem declaração" (pessoas que não responderam à pergunta), as frequências foram também reduzidas para os que se declararam "indígenas" na pergunta sobre "cor ou raça" ( $<2 \%$ em todas as regiões, urbano e rural). Não obstante, para os que "se consideram indígenas", o padrão foi bastante distinto. Nas várias regiões, com exceção do Sudeste urbano (onde somente nove pessoas "se consideraram" indígenas), 40\% ou mais dos indivíduos que "se consideram indígenas" não responderam à pergunta sobre etnia ou povo em ambas situações (urbana e rural).

Para a análise da pergunta "se considera indígena" no conjunto das 501 TIs² investigadas pelo IBGE no Censo 2010, optou-se por identificar as TIs em que a pergunta teve maior impacto, ou seja, aquelas que foram responsáveis pela classificação de mais indivíduos como indígenas segundo a metodologia aplicada. Dessa maneira, procurou-se averiguar se a não declaração como indígena ocorreu de forma dispersa ou se houve uma concentração em algumas TIs; e, em caso positivo, qual seria o perfil destas. Para tal, foram conduzidas três etapas de análise. Primeiro, foram identificadas as TIs em que uma grande proporção da população (mais de 80\%) não se declarou indígena. Segundo, foram identificadas as TIs nas quais mais de $80 \%$ da população residente se considerou indígena. Na terceira etapa, foram destacadas as TIs em que houve uma grande quantidade de pessoas (mais de 1.001 residentes, em 20 TIs) que se consideraram indígenas.

Considerando-se o recorte da primeira etapa, 39 TIs (7,8\%) tiveram 80\% ou mais da população que não se declarou "indígena" na pergunta sobre "cor ou raça" (Tabela 4). Dessas, 17 se localizavam na região Norte, três no Nordeste, 14 no Centro-Oeste, uma no Sudeste e quatro no Sul. Das 30.691 pessoas que não se declararam indígenas nem se consideraram como tal em todo o país, 21.595 (70,4\% do total) se encontravam nessas 39 TIs, com destaque para a TI Fulni-Ô - PE, com 18.647 pessoas. Quanto ao montante de pessoas para as quais não se obtiveram 
respostas ("ignorado") no país como um todo (19.508 pessoas), esse conjunto de TIs é também expressivo, com 9.093 indivíduos, ou 46,6\%, com destaque para Guarani do Ribeirão - SP (2.560 pessoas), Xukuru de Cimbres - PE (1.440), Boa Vista - PR (1.110) e Vale do Guaporé - MT (1.090). Cabe indicar, no entanto, que esse conjunto de 39 TIs soma uma porcentagem relativamente baixa, mas não obstante expressiva, do total de residentes em TIs que "se consideraram indígenas" (19.373 pessoas, o que corresponde a $24,5 \%$ do total de 78.954 indivíduos) (Tabela 4).

Na segunda etapa, foram identificadas 15 TIs que apresentaram $80 \%$ ou mais de pessoas que "se consideraram" indígenas. Todas essas TIs foram também identificadas na primeira etapa e estão sinalizadas com símbolo (\#) na Tabela 4. Dessas, 11 estavam na região Norte, três no Centro-Oeste e uma no Sul. Essas TIs somaram 5.335 pessoas que "se consideraram" indígenas, ou seja, 6,8\% dos 78.954 no país como um todo. Portanto, nesse recorte específico de TIs residia uma quantidade relativamente reduzida de indivíduos que "se consideraram" indígenas.

Finalmente, na terceira etapa, que envolveu identificar as TIs com maior quantidade de indivíduos que "se consideraram" indígenas, obteve-se um conjunto de 20 TIs (Tabela 5), das quais oito se localizavam no Norte, nove no Nordeste e três no Centro-Oeste, totalizando 34.545 pessoas, o que correspondeu a 43,8\% do total de indivíduos nesse grupo em todo o país. Dentre essas 20 TI, apenas cinco aparecem também listadas na Tabela 4.

Nessas etapas referidas, tem-se, assim, um conjunto de 54 TIs (39 das primeira e segunda etapas e 20 da terceira, sendo cinco em comum) nas quais as respostas para a pergunta "se considera" foram particularmente expressivas, correspondendo a 45.261 registros (Tabela 6). Nessas 54 TIs, o que equivale a $11 \%$ das 501 TIs investigadas, residiam 45.261 (57,3\%) dos 78.954 indivíduos que se consideraram indígenas no país. Ou seja, a pergunta "se considera" foi responsável nessas áreas pela identificação de expressivo volume de população indígena.

A comparação entre os dados do Censo 2010 e aqueles disponibilizados pelo ISA foi possível para 51 das 54 TIs listadas na Tabela 6. Apenas 16 tiveram os tamanhos de população recenseada próximos daqueles divulgados pelo ISA. No caso de nove TIs, o IBGE recenseou menos indivíduos (razão $<1$ ). Para as demais 26 TIs, a população recenseada superou em duas vezes ou mais os montantes divulgados pelo ISA. Em sete casos, o contingente de pessoas recenseadas chegou ultrapassar em dez vezes ou mais (Tabela 6).

Nessas 26s TI, o volume de população não indígena (ou seja, "brancos", "pretos", "amarelos" e "pardos") foi de 51.308. Desse montante, 27.215 "se consideraram" indígenas (53,0\%), o que corresponde a 34,5\% do total do país. Portanto, em apenas 26 TIs, cuja característica em comum é um maior volume de residentes identificados pelo IBGE se comparado ao ISA, houve a concentração de aproximadamente um terço dos indivíduos que "se consideraram indígenas". 
Tabela 1 - População indígena ("cor" ou "raça" e categorias de "se considera") residente em terras indígenas segundo situação

\begin{tabular}{|c|c|c|c|c|c|c|c|c|c|c|}
\hline & \multicolumn{5}{|c|}{ Urbana } & \multicolumn{5}{|c|}{ Rural } \\
\hline & \multirow{2}{*}{$\begin{array}{c}\text { Cor ou raça } \\
\text { indígena } \\
(\%)\end{array}$} & \multicolumn{3}{|c|}{ "Se considera indígena?" } & \multirow[b]{2}{*}{$\begin{array}{c}\text { Total } \\
(\%)\end{array}$} & \multirow{2}{*}{$\begin{array}{c}\text { Cor ou raça } \\
\text { indígena } \\
(\%)\end{array}$} & \multicolumn{3}{|c|}{ "Se considera indígena?" } & \multirow[b]{2}{*}{$\begin{array}{c}\text { Total } \\
(\%)\end{array}$} \\
\hline & & $\begin{array}{l}\text { Sim } \\
(\%)\end{array}$ & $\begin{array}{l}\text { Não } \\
(\%)\end{array}$ & $\begin{array}{l}\text { Ignorado } \\
(\%)\end{array}$ & & & $\begin{array}{l}\text { Sim } \\
(\%)\end{array}$ & $\begin{array}{c}\text { Não } \\
(\%)\end{array}$ & $\begin{array}{c}\text { Ignorado } \\
(\%)\end{array}$ & \\
\hline & 16.321 & 9.642 & 19.569 & 8.897 & 54.429 & 422.108 & 69.312 & 11.122 & 10.611 & 513.153 \\
\hline \multicolumn{11}{|l|}{ Região } \\
\hline Norte & 13,1 & 0,5 & 0,0 & 38,9 & 10,4 & 50,4 & 53,3 & 49,2 & 38,6 & 50,5 \\
\hline Nordeste & 66,9 & 85,4 & 98,0 & 22,3 & 74,1 & 16,9 & 22,8 & 25,0 & 26,0 & 18,0 \\
\hline Sudeste & 3,9 & 0,1 & 0,0 & 28,5 & 5,9 & 3,3 & 1,7 & 0,3 & 0,3 & 3,0 \\
\hline Sul & 7,1 & 4,5 & 0,6 & 9,8 & 4,8 & 8,2 & 4,9 & 6,3 & 14,6 & 7,8 \\
\hline Centro-Oeste & 9,0 & 9,5 & 1,4 & 0,5 & 5,0 & 21,2 & 17,3 & 19,1 & 20,5 & 20,6 \\
\hline \multicolumn{11}{|l|}{ Sexo } \\
\hline Masculino & 50,3 & 49,7 & 46,6 & 50,9 & 49,0 & 51,3 & 54,1 & 54,3 & 58,6 & 51,9 \\
\hline Feminino & 49,7 & 50,3 & 53,4 & 49,1 & 51,0 & 48,7 & 45,9 & 45,7 & 41,4 & 48,1 \\
\hline \multicolumn{11}{|l|}{ Idade } \\
\hline 0 a 9 anos & 27,2 & 17,3 & 20,4 & 17,8 & 21,5 & 32,8 & 24,0 & 23,9 & 18,2 & 31,1 \\
\hline 10 a 19 anos & 23,3 & 20,0 & 20,4 & 19,6 & 21,1 & 24,6 & 21,8 & 19,5 & 19,3 & 24,0 \\
\hline 20 a 39 anos & 30,0 & 30,4 & 30,9 & 32,3 & 30,8 & 26,9 & 31,7 & 32,8 & 31,6 & 27,7 \\
\hline 40 a 59 anos & 12,8 & 20,6 & 17,2 & 20,1 & 16,9 & 10,2 & 16,4 & 17,4 & 20,8 & 11,4 \\
\hline 60 anos e mais & 6,7 & 11,8 & 11,0 & 10,3 & 9,7 & 5,5 & 6,1 & 6,4 & 10,1 & 5,7 \\
\hline \multicolumn{11}{|l|}{ Alfabetização* } \\
\hline Sim & 75,8 & 74,4 & 65,3 & 85,3 & 73,3 & 63,5 & 73,0 & 69,6 & 72,8 & 65,2 \\
\hline Não & 24,2 & 25,6 & 34,7 & 14,7 & 26,7 & 36,5 & 27,0 & 30,4 & 27,2 & 34,8 \\
\hline \multicolumn{11}{|l|}{ Renda per capita** } \\
\hline Não tem & 54,4 & 44,9 & 40,7 & 38,1 & 44,8 & 68,1 & 59,2 & 58,0 & 48,3 & 66,0 \\
\hline Até $1 \mathrm{SM}$ & 36,6 & 44,4 & 47,1 & 31,1 & 40,9 & 26,8 & 29,0 & 27,0 & 34,9 & 27,4 \\
\hline Mais de 1 e até 3 SM & 7,7 & 9,2 & 9,5 & 24,1 & 11,4 & 4,6 & 10,2 & 13,2 & 14,6 & 5,9 \\
\hline Mais de $3 \mathrm{SM}$ & 1,2 & 1,5 & 2,8 & 6,6 & 2,8 & 0,5 & 1,5 & 1,8 & 2,2 & 0,7 \\
\hline \multicolumn{11}{|l|}{ Quem foi o informante? } \\
\hline A própria pessoa & 30,2 & 33,4 & 33,9 & 39,5 & 33,6 & 25,4 & 36,3 & 44,6 & 39,8 & 27,6 \\
\hline Outro morador & 66,4 & 64,5 & 63,9 & 56,9 & 63,6 & 58,3 & 58,2 & 52,1 & 56,0 & 58,1 \\
\hline Não morador & 3,4 & 2,0 & 2,2 & 3,6 & 2,7 & 16,3 & 5,6 & 3,3 & 4,2 & 14,3 \\
\hline \multicolumn{11}{|l|}{ Cor ou raça declarada } \\
\hline Branca & - & 33,5 & 37,6 & 33,5 & 35,6 & - & 21,2 & 25,6 & 28,9 & 22,6 \\
\hline Preta & - & 6,0 & 4,6 & 10,9 & 6,4 & - & 8,5 & 10,6 & 7,7 & 8,6 \\
\hline Amarela & - & 1,0 & 1,0 & 1,1 & 1,0 & - & 1,7 & 0,9 & 1,4 & 1,6 \\
\hline Parda & - & 59,4 & 56,8 & 54,5 & 56,9 & - & 68,7 & 62,9 & 62,0 & 67,2 \\
\hline
\end{tabular}

* Inclui somente pessoas com idades $\geq 5$ anos

** Inclui somente pessoas com idades $\geq 10$ anos

Fonte: Censo Demográfico 2010. 
Tabela 2 - População residente em terras indígenas que "se considera indígena" segundo situação do domicílio (urbana e rural). Brasil - 2010

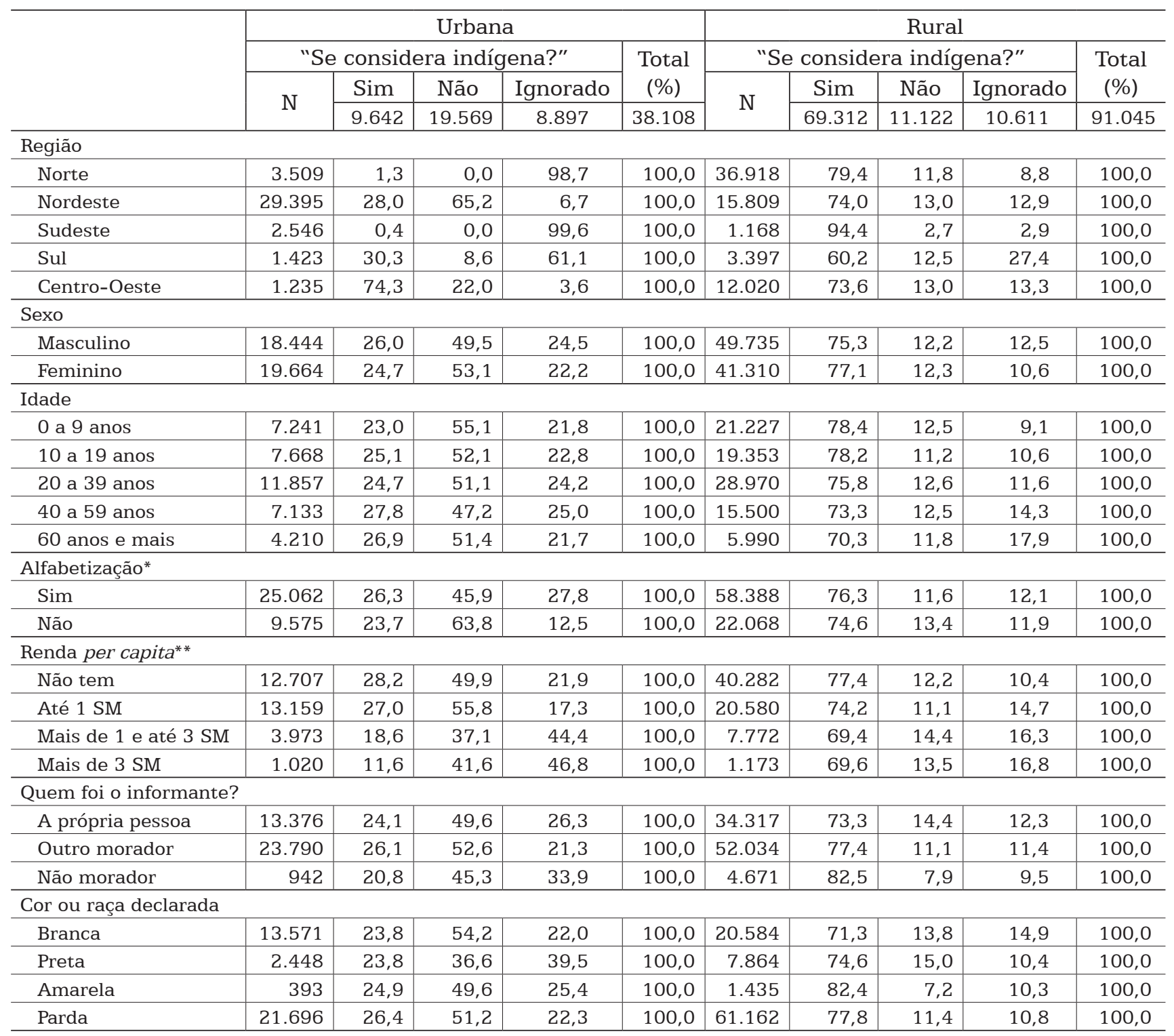

* Inclui somente pessoas com idades $\geq 5$ anos

** Inclui somente pessoas com idades $\geq 10$ anos

Fonte: Censo Demográfico 2010. 
Tabela 3 - População indígena (cor ou raça "indígena" e "se considera") residente em terras indígenas segundo região geográfica de acordo com situação do domicílio (urbana e rural). Brasil - 2010

\begin{tabular}{|c|c|c|c|c|c|c|}
\hline & \multicolumn{2}{|c|}{ Urbana } & \multicolumn{2}{|c|}{ Rural } & \multicolumn{2}{|c|}{ Total } \\
\hline & $\begin{array}{c}\text { Total } \\
\text { indígenas }\end{array}$ & $\begin{array}{c}\% \text { "se } \\
\text { considera } \\
\text { indígena" }\end{array}$ & $\begin{array}{c}\text { Total } \\
\text { indígenas }\end{array}$ & $\begin{array}{c}\% \text { "se } \\
\text { considera } \\
\text { indígena" }\end{array}$ & $\begin{array}{c}\text { Total } \\
\text { indígenas }\end{array}$ & $\begin{array}{c}\% \text { "se } \\
\text { considera } \\
\text { indígena" }\end{array}$ \\
\hline & 25.963 & 37,1 & 491.417 & 14,1 & 517.380 & 15,3 \\
\hline Norte & 2.179 & 2,1 & 249.712 & 14,8 & 251.891 & 14,7 \\
\hline Nordeste & 19.159 & 43,0 & 86.983 & 18,2 & 106.142 & 22,7 \\
\hline Sudeste & 652 & 1,4 & 15.252 & 7,7 & 15.904 & 7,4 \\
\hline Sul & 1.594 & 27,0 & 37.833 & 9,0 & 39.427 & 9,7 \\
\hline Centro-Oeste & 2.379 & 38,6 & 101.640 & 11,8 & 104.019 & 12,4 \\
\hline
\end{tabular}

Fonte: Censo Demográfico 2010.

Figura 1 - Composição relativa da população indígena (sexo e grupos de idade) segundo as categorias de identificação de indígenas de acordo com situação urbana e rural dos domicílios localizados em terras indígenas. Brasil - 2010
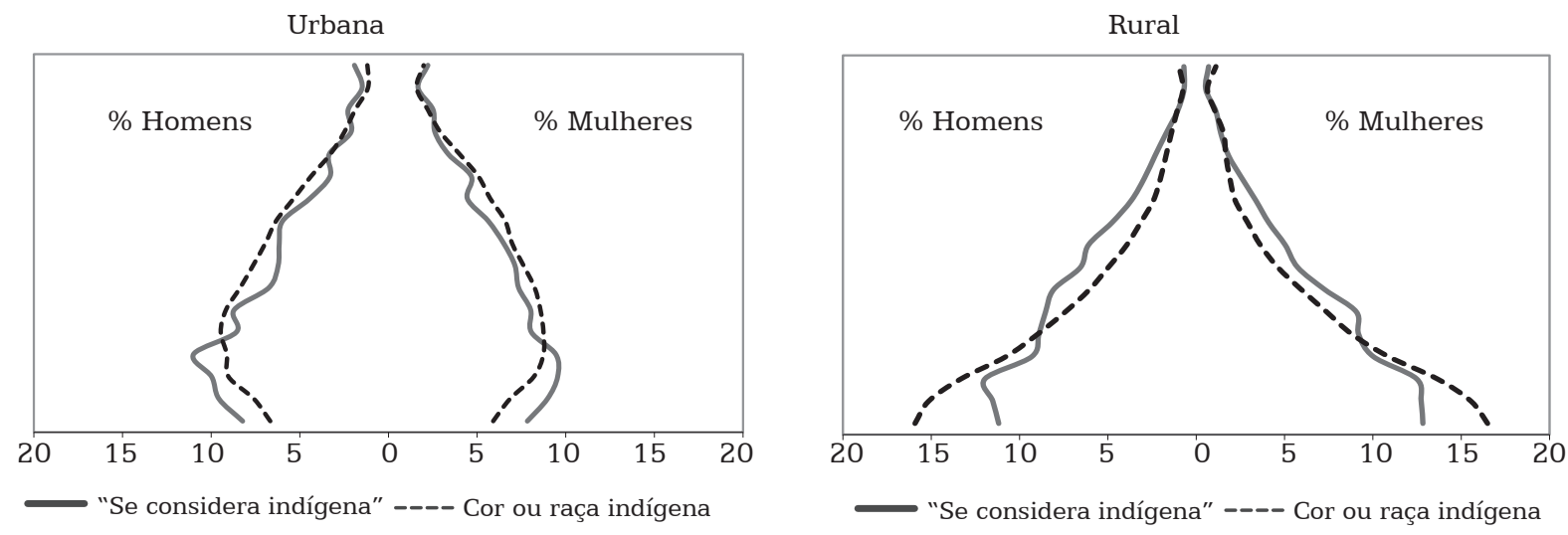

Fonte: Censo Demográfico, 2010. 
Tabela 4 - Terras indígenas com 80\% ou mais de indivíduos que não se declararam "indígenas" na pergunta sobre "cor ou raça". Brasil - 2010

\begin{tabular}{|c|c|c|c|c|c|c|c|}
\hline \multirow{2}{*}{ Região } & \multirow{3}{*}{ Terra indígena (UF) } & \multirow{2}{*}{$\begin{array}{l}\text { "Cor ou } \\
\text { raça" } \\
\text { indígena }\end{array}$} & \multicolumn{3}{|c|}{ "Se considera indígena?" } & \multirow{2}{*}{$\begin{array}{l}\text { Total que } \\
\text { respondeu à } \\
\text { pergunta "se } \\
\text { considera" }\end{array}$} & \multirow{2}{*}{$\begin{array}{c}\text { Total } \\
\text { população }\end{array}$} \\
\hline & & & Sim & Não & Ignorado & & \\
\hline Brasil & & $\begin{array}{l}438.429 \\
(77,2 \%) \\
\end{array}$ & $\begin{array}{c}78.954 \\
(13,9 \%) \\
\end{array}$ & $\begin{array}{l}30.691 \\
(5,4 \%) \\
\end{array}$ & $\begin{array}{l}19.508 \\
(3,4 \%) \\
\end{array}$ & $\begin{array}{l}129.153 \\
(22,8 \%) \\
\end{array}$ & $\begin{array}{c}567.582 \\
(100 \%) \\
\end{array}$ \\
\hline \multirow{17}{*}{ Norte } & Kaxinawá da Praia do Carapanã (AC)\# & $0(0 \%)$ & $571(99,7 \%)$ & $2(0,3 \%)$ & 0 & $573(100 \%)$ & $573(100 \%)$ \\
\hline & Jaminawa / Envira (AC)\# & $7(9,1 \%)$ & $70(90,9 \%)$ & 0 & 0 & $70(90,9 \%)$ & 77 (100\%) \\
\hline & Riozinho do Alto Envira (AC)\# & 0 & $101(100 \%)$ & 0 & 0 & $101(100 \%)$ & $101(100 \%)$ \\
\hline & Ilha do Camaleão (AM)\# & $14(3,2 \%)$ & $371(85,9 \%)$ & $47(10,9 \%)$ & 0 & $418(96,8 \%)$ & $432(100 \%)$ \\
\hline & Acapuri de Cima (AM)\# & $15(5,3 \%)$ & $269(94,7 \%)$ & 0 & 0 & $269(94,7 \%)$ & $284(100 \%)$ \\
\hline & Cajuhiri Atravessado (AM) & $69(14 \%)$ & $377(76,6 \%)$ & $44(8,9 \%)$ & $2(0,4 \%)$ & $423(86 \%)$ & $492(100 \%)$ \\
\hline & Paraná do Arauató (AM) & $7(13,2 \%)$ & $40(75,5 \%)$ & $6(11,3 \%)$ & 0 & $46(86,8 \%)$ & $53(100 \%)$ \\
\hline & Porto Limoeiro (AM)\# & 0 & $119(92,2 \%)$ & $10(7,8 \%)$ & 0 & $129(100 \%)$ & 129 (100\%) \\
\hline & Apurinã do Igarapé Mucuim (AM)\# & $62(11,3 \%)$ & $444(81,2 \%)$ & $26(4,8 \%)$ & $15(2,7 \%)$ & $485(88,7 \%)$ & $547(100 \%)$ \\
\hline & Apyterewa (PA) & $387(9,1 \%)$ & $3.201(75,2 \%)$ & $610(14,3 \%)$ & $57(1,3 \%)$ & $3.868(90,9 \%)$ & $4.255(100 \%)$ \\
\hline & Cachoeira Seca (PA) & $98(3,5 \%)$ & $2.191(79,3 \%)$ & $423(15,3 \%)$ & $51(1,85)$ & $2.665(96,5 \%)$ & $2.763(100 \%)$ \\
\hline & Sarauá (PA) & $184(15,2 \%)$ & $926(76,3 \%)$ & $99(8,2 \%)$ & $4(0,3 \%)$ & $1.02984,8 \%)$ & $1.213(100 \%)$ \\
\hline & Anta (RR)\# & 0 & $99(86,1 \%)$ & $14(12,2 \%)$ & $2(1,7 \%)$ & $115(100 \%)$ & $115(100 \%)$ \\
\hline & Canauanim (RR)\# & $59(7,1 \%)$ & $773(92,7 \%)$ & $1(0,1 \%)$ & $1(0,1 \%)$ & $775(92,9 \%)$ & $834(100 \%)$ \\
\hline & Ponta da Serra (RR)\# & 0 & $168(96 \%)$ & 0 & $7(4 \%)$ & $175(100 \%)$ & $175(100 \%)$ \\
\hline & Raimundão (RR)\# & $38(10,5 \%)$ & $313(86,2 \%)$ & $12(3,3 \%)$ & 0 & $325(89,5 \%)$ & $363(100 \%)$ \\
\hline & Krahô-Kanela (TO) & $1(0,1 \%)$ & $579(78,1 \%)$ & $136(18,4 \%)$ & $25(3,4 \%)$ & $740(99,9 \%)$ & $741(100 \%)$ \\
\hline \multirow{3}{*}{ Nordeste } & Awá (MA) & $2(0,2 \%)$ & $363(40,7 \%)$ & $71(8 \%)$ & $455(51,1 \%)$ & $889(99,9 \%)$ & $891(100 \%)$ \\
\hline & Fulni-Ô (PE) & $3.423(14,3 \%)$ & $1.040(4,4 \%)$ & $18.647(78,1 \%)$ & $772(3,2 \%)$ & $20.459(85,7 \%)$ & $23.882(100 \%)$ \\
\hline & Xukuru de Cimbres (PE) & $10(0,7 \%)$ & 0 & 0 & $1.440(99,3 \%)$ & $1.440(99,3 \%)$ & $1.450(100 \%)$ \\
\hline \multirow{4}{*}{$\begin{array}{l}\text { Centro- } \\
\text { Oeste }\end{array}$} & Bakairi (MT)\# & $17(2,8 \%)$ & $595(96,6 \%)$ & 0 & $4(0,6 \%)$ & $599(97,2 \%)$ & $616(100 \%)$ \\
\hline & Kayabi (MT) & $9(16,7 \%)$ & $36(66,7 \%)$ & $8(14,8 \%)$ & $1(1,9 \%)$ & $45(83,3 \%)$ & $54(100 \%)$ \\
\hline & Vale do Guaporé (MT) & $482(16,1 \%)$ & $1.114(37,2 \%)$ & $305(10,2 \%)$ & $1.090(36,4 \%)$ & $2.509(83,9 \%)$ & $2991(100 \%)$ \\
\hline & Figueiras (MT)\# & $22(2,9 \%)$ & 641 (85\%) & $75(9,9 \%)$ & $16(2,1 \%)$ & $732(97,1 \%)$ & 754 (100\%) \\
\hline
\end{tabular}


$\ddot{\&}$ Tabela 4 - Terras indígenas com 80\% ou mais de indivíduos que não se declararam "indígenas" na pergunta sobre "cor ou raça". Brasil - 2010 (cont.)

\begin{tabular}{|c|c|c|c|c|c|c|c|}
\hline \multirow{2}{*}{ Região } & \multirow{3}{*}{ Terra indígena (UF) } & \multirow{2}{*}{$\begin{array}{c}\text { "Cor ou } \\
\text { raça" } \\
\text { indígena }\end{array}$} & \multicolumn{3}{|c|}{ "Se considera indígena?" } & \multirow{2}{*}{$\begin{array}{l}\text { Total que } \\
\text { respondeu à } \\
\text { pergunta "se } \\
\text { considera" }\end{array}$} & \multirow{2}{*}{$\begin{array}{c}\text { Total } \\
\text { população }\end{array}$} \\
\hline & & & Sim & Não & Ignorado & & \\
\hline Brasil & & $\begin{array}{l}438.429 \\
(77,2 \%) \\
\end{array}$ & $\begin{array}{c}78.954 \\
(13,9 \%)\end{array}$ & $\begin{array}{l}30.691 \\
(5,4 \%)\end{array}$ & $\begin{array}{l}19.508 \\
(3,4 \%)\end{array}$ & $\begin{array}{l}129.153 \\
(22,8 \%)\end{array}$ & $\begin{array}{c}567.582 \\
(100 \%)\end{array}$ \\
\hline \multirow{10}{*}{$\begin{array}{l}\text { Centro- } \\
\text { Oeste }\end{array}$} & Marechal Rondon (MT)\# & 0 & $548(99,8 \%)$ & 0 & $1(0,2 \%)$ & 549 (100\%) & 549 (100\%) \\
\hline & Jarudore (MT) & $29(5,4 \%)$ & $384(71,1 \%)$ & $100(18,5 \%)$ & 27 (5\%) & $511(94,6 \%)$ & $540(100 \%)$ \\
\hline & Taihantesu (MT) & $45(9,9 \%)$ & $173(37,9 \%)$ & $12(2,6 \%)$ & $226(49,6 \%)$ & $411(90,1 \%)$ & $456(100 \%)$ \\
\hline & Chão Preto (MT) & 0 & $255(75,7 \%)$ & $73(21,7 \%)$ & $9(2,7 \%)$ & 337 (100\%) & $337(100 \%)$ \\
\hline & Ponte de Pedra (MT) & 0 & $234(61,6 \%)$ & $37(9,7 \%)$ & $109(28,7 \%)$ & $380(100 \%)$ & $380(100 \%)$ \\
\hline & Uirapuru (MT) & 0 & $238(62 \%)$ & $132(34,4 \%)$ & $14(3,65)$ & $384(100 \%)$ & $384(100 \%)$ \\
\hline & Portal do Encantado (MT) & $166(13,7 \%)$ & $880(72,5 \%)$ & $126(10,4 \%)$ & $41(3,4 \%)$ & $1.047(86,3 \%)$ & $1.213(100 \%)$ \\
\hline & Pequizal do Navurôtu (MT) & $1(0,1 \%)$ & $1.111(72,3 \%)$ & $367(23,9 \%)$ & $58(3,8 \%)$ & $1.536(99,9 \%)$ & $1.537(100 \%)$ \\
\hline & Krenrehé (MT) & $19(14,3 \%)$ & $22(16,5 \%)$ & $10(7,5 \%)$ & $82(61,7 \%)$ & $114(85,7 \%)$ & $133(100 \%)$ \\
\hline & Guyraroká (MS) & $112(18,7 \%)$ & $413(68,9 \%)$ & $52(8,7 \%)$ & $22(3,7 \%)$ & $487(81,3 \%)$ & 599 (100\%) \\
\hline Sudeste & Guarani do Ribeirão (SP) & $328(11,3 \%)$ & $4(0,1 \%)$ & 0 & $2.560(88,5 \%)$ & $2.564(88,7 \%)$ & $2.892(100 \%)$ \\
\hline \multirow{4}{*}{ Sul } & Boa Vista (PR) & $116(9,5 \%)$ & 0 & 0 & $1.110(90,5 \%)$ & $1.110(90,5 \%)$ & $1.226(100 \%)$ \\
\hline & Toldo Pinhal (SC) & $105(13,1 \%)$ & $433(54,1 \%)$ & $100(12,5 \%)$ & $163(20,3 \%)$ & $696(86,9 \%)$ & $801(100 \%)$ \\
\hline & Guarani do Araça'i (SC)\# & 0 & 253 (83\%) & $50(16,4 \%)$ & $2(0,7 \%)$ & $305(100 \%)$ & 305 (100\%) \\
\hline & Toldo Imbu (SC) & $133(15 \%)$ & $24(2,7 \%)$ & 0 & $727(82,2 \%)$ & 751 (85\%) & $884(100 \%)$ \\
\hline \multicolumn{2}{|l|}{ Total $^{*}$} & $5.960(1,4 \%)$ & $19.373(24,5 \%)$ & $21.595(70,4 \%)$ & $9.093(46,6 \%)$ & $50.061(38,8 \%)$ & $56.021(9,9 \%)$ \\
\hline
\end{tabular}

\# TIs nas quais $80 \%$ ou mais de indivíduos se consideraram indígenas

* Proporção da soma desse conjunto com o total das TIs no Brasil

Fonte: Censo Demográfico 2010. 
Tabela 5 - Terras indígenas em que mais de 1.001 indivíduos não se declararam, mas se consideraram "indígenas". Brasil - 2010

\begin{tabular}{|c|c|c|c|c|}
\hline Região & Estado & Terra indígena & $\begin{array}{l}\text { Não se declarou, mas } \\
\text { se considerou indígena }\end{array}$ & Total população \\
\hline \multirow{8}{*}{ Norte } & \multirow{3}{*}{ Amazonas } & Yanomami - AM/RR & $1.356(5,2 \%)$ & 25.972 \\
\hline & & Évare I & $1.201(7,1 \%)$ & 16.890 \\
\hline & & Tikúna de Feijoal & $1.179(25,4 \%)$ & 4.645 \\
\hline & Roraima & Raposa Serra do Sol & $2.462(13,9 \%)$ & 17.750 \\
\hline & \multirow{4}{*}{ Pará } & Apyterewa & $3.201(75,25 \%$ & 4.255 \\
\hline & & Alto Rio Guamá & $2.546(61,1 \%)$ & 4.168 \\
\hline & & Cachoeira Seca & $2.191(79,3 \%)$ & 2.763 \\
\hline & & Munduruku & $1.185(26 \%)$ & 4.566 \\
\hline \multirow{9}{*}{ Nordeste } & Alagoas & Wassu-Cocal & $1.059(47,4 \%)$ & 2.234 \\
\hline & Bahia & Caramuru / Paraguassu & $1.719(36,7 \%)$ & 4.678 \\
\hline & Ceará & Pitaguary & $1.361(50,5 \%)$ & 2.694 \\
\hline & Maranhão & Porquinhos & $1.175(45,2 \%)$ & 2.600 \\
\hline & Paraíba & Potiguara de Monte-Mor & $4.781(47,3 \%)$ & 10.106 \\
\hline & \multirow{4}{*}{ Pernambuco } & Potiguara & $1.091(12,2 \%)$ & 8.971 \\
\hline & & Xukuru & $2.141(27,7 \%)$ & 7.727 \\
\hline & & Entre-Serras & $1.454(45,7 \%)$ & 3.181 \\
\hline & & Fulni-ô & $1.040(4,4 \%)$ & 23.882 \\
\hline \multirow{3}{*}{ Centro-Oeste } & \multirow{3}{*}{ Mato Grosso } & Maraiwatsede & $1.178(48,5 \%)$ & 2.427 \\
\hline & & Vale do Guaporé & $1.114(37,2 \%)$ & 2.991 \\
\hline & & Pequizal do Naruvôtu & $1.111(72,3 \%)$ & 1.537 \\
\hline \multicolumn{3}{|l|}{ Total $^{*}$} & $34.545(43,8 \%)$ & $154.037(27,1 \%)$ \\
\hline
\end{tabular}

* Proporção da soma desse conjunto com o total das TIs no Brasil (Tabela 4)

Fonte: Censo Demográfico 2010. 
Tabela 6 - Comparação de resultados de contagem de população segundo IBGE e ISA para conjunto selecionado de terras indígenas

\begin{tabular}{|c|c|c|c|c|c|c|c|c|c|c|}
\hline \multirow{2}{*}{ Terra indígena } & \multirow{2}{*}{$\begin{array}{l}\text { Se declarou } \\
\text { indígena }\end{array}$} & \multicolumn{3}{|c|}{ "Se considera indígena?" } & \multirow{2}{*}{$\begin{array}{l}\text { Etnia } \\
(\text { sim) }\end{array}$} & \multirow{2}{*}{$\begin{array}{c}\text { Etnia (mal } \\
\text { definida, mal } \\
\text { determinada, } \\
\text { não sabem) }\end{array}$} & \multirow{2}{*}{$\begin{array}{c}\text { Sem } \\
\text { declaração } \\
\text { de etnia }\end{array}$} & \multirow{2}{*}{$\begin{array}{l}\text { Total } \\
\text { população } \\
\text { IBGE }\end{array}$} & \multirow{2}{*}{$\begin{array}{l}\text { Dados } \\
\text { ISA }\end{array}$} & \multirow{2}{*}{$\begin{array}{l}\text { Razão } \\
\text { IBGE/ } \\
\text { ISA }\end{array}$} \\
\hline & & Sim & Não & Ignorado & & & & & & \\
\hline $\begin{array}{l}\text { Kaxinawá da Praia do } \\
\text { Carapanã }\end{array}$ & 0 & 571 & 2 & 0 & * & * & * & 573 & 485 & 1,18 \\
\hline Jaminawa / Envira & 7 & 70 & 0 & 0 & * & * & * & 77 & 111 & 0,69 \\
\hline $\begin{array}{l}\text { Riozinho do Alto } \\
\text { Envira }\end{array}$ & 0 & 101 & 0 & 0 & * & * & * & 101 & 10 & 0,96 \\
\hline Ilha do Camaleão & 14 & 371 & 47 & 0 & * & * & * & 432 & 565 & 0,76 \\
\hline Acapuri de Cima & 15 & 269 & 0 & 0 & * & * & * & 284 & 237 & 1,20 \\
\hline $\begin{array}{l}\text { Apurinã do Igarapé } \\
\text { Mucuim }\end{array}$ & 62 & 444 & 26 & 15 & * & * & * & 547 & 93 & 5,88 \\
\hline Cajuhiri Atravessado & 69 & 377 & 44 & 2 & * & * & * & 492 & 51 & 9,65 \\
\hline Évare I & 15.485 & 1.201 & 45 & 159 & 1.083 & 3 & 117 & 16.890 & 18.086 & 0,93 \\
\hline Paraná do Arauató & 7 & 40 & 6 & 0 & * & * & * & 53 & 103 & 0,51 \\
\hline Porto Limoeiro & 0 & 119 & 10 & 0 & * & * & * & 129 & 31 & 4,16 \\
\hline Tikúna de Feijoal & 3.302 & 1.179 & 158 & 6 & * & * & * & 4.645 & 4.510 & 1,03 \\
\hline Yanomami (AM-RR) & 24.363 & 1.356 & 181 & 72 & 73 & 3 & 1.291 & 25.972 & 18.589 & 1,40 \\
\hline Alto Rio Guamá & 1.202 & 2.546 & 370 & 50 & 44 & 11 & 2.499 & 4.168 & 1.502 & 2,77 \\
\hline Apyterewa & 387 & 3.201 & 610 & 57 & 3 & 0 & 3.200 & 4.255 & 452 & 9,41 \\
\hline Cachoeira Seca & 98 & 2.191 & 423 & 51 & 9 & 3 & 2.184 & 2.763 & 86 & 32,13 \\
\hline Munduruku & 3.313 & 1.185 & 62 & 6 & 60 & 3 & 1.126 & 4.566 & 6.038 & 0,76 \\
\hline Sarauá & 184 & 926 & 99 & 4 & 18 & 0 & 908 & 1.213 & 184 & 6,59 \\
\hline Anta & 0 & 99 & 14 & 2 & * & * & * & 115 & 159 & 0,72 \\
\hline Canauanim & 59 & 773 & 1 & 1 & 741 & 3 & 33 & 834 & 846 & 0,99 \\
\hline Ponta da Serra & 0 & 168 & 0 & 7 & * & * & * & 175 & 235 & 0,74 \\
\hline Raimundão & 38 & 313 & 12 & 0 & * & * & * & 363 & 265 & 1,37 \\
\hline Raposa Serra do Sol & 14.640 & 2.462 & 114 & 534 & 2.202 & 3 & 258 & 17.750 & 19.933 & 0,89 \\
\hline Krahô-Kanela & 1 & 579 & 136 & 25 & * & * & * & 741 & 67 & 11,06 \\
\hline Wassu-Cocal & 1.023 & 1.059 & 100 & 52 & 315 & 17 & 727 & 2.234 & 1.806 & 1,24 \\
\hline $\begin{array}{l}\text { Caramuru / } \\
\text { Paraguassu }\end{array}$ & 2.241 & 1.719 & 648 & 70 & 186 & 44 & 1.496 & 4.678 & 2.293 & 2,04 \\
\hline Pitaguary & 1.218 & 1.361 & 95 & 20 & 621 & 3 & 741 & 2.694 & 2.740 & 0,98 \\
\hline Awá & 2 & 363 & 71 & 455 & 3 & 0 & 360 & 891 & 42 & 21,21 \\
\hline Porquinhos & 587 & 1.175 & 816 & 22 & 3 & 0 & 1.174 & 2.600 & 677 & 3,84 \\
\hline
\end{tabular}




\begin{tabular}{|c|c|c|c|c|c|c|c|c|c|c|}
\hline \multirow{2}{*}{ Terra indígena } & \multirow{2}{*}{$\begin{array}{l}\text { Se declarou } \\
\text { indígena }\end{array}$} & \multicolumn{3}{|c|}{ "Se considera indígena?" } & \multirow{2}{*}{$\begin{array}{l}\text { Etnia } \\
(\operatorname{sim})\end{array}$} & \multirow{2}{*}{$\begin{array}{c}\text { Etnia (mal } \\
\text { definida, mal } \\
\text { determinada, } \\
\text { não sabem) }\end{array}$} & \multirow{2}{*}{$\begin{array}{c}\text { Sem } \\
\text { declaração } \\
\text { de etnia }\end{array}$} & \multirow{2}{*}{$\begin{array}{l}\text { Total } \\
\text { população } \\
\text { IBGE }\end{array}$} & \multirow{2}{*}{$\begin{array}{l}\text { Dados } \\
\text { ISA }\end{array}$} & \multirow{2}{*}{$\begin{array}{c}\text { Razão } \\
\text { IBGE/ } \\
\text { ISA }\end{array}$} \\
\hline & & Sim & Não & Ignorado & & & & & & \\
\hline $\begin{array}{l}\text { Potiguara de Monte- } \\
\text { Mor }\end{array}$ & 4.362 & 4.781 & 472 & 491 & 2.147 & 8 & 2.628 & 10.106 & 3.002 & 3,37 \\
\hline Potiguara & 7.624 & 1.091 & 226 & 30 & 724 & 3 & 363 & 8.971 & 14.831 & 0,60 \\
\hline Entre-Serras & 1.578 & 1.454 & 74 & 75 & 969 & 0 & 487 & 3.181 & 1.072 & 2,97 \\
\hline Fulni-Ô & 3.423 & 1.040 & 18.647 & 772 & 954 & 90 & 0 & 23.882 & 3.775 & 6,33 \\
\hline Xukuru & 5.531 & 2.141 & 50 & 5 & 1.972 & 0 & 168 & 7.727 & 10.536 & 0,73 \\
\hline Xukuru de Cimbres & 10 & 0 & 0 & 1.440 & * & * & * & 1.450 & 12.006 & 0,12 \\
\hline Bakairi & 17 & 595 & 0 & 4 & * & * & * & 616 & 606 & 1,02 \\
\hline Kayabi & 9 & 36 & 8 & 1 & * & * & * & 54 & 647 & 0,08 \\
\hline Vale do Guaporé & 482 & 1.114 & 305 & 1.090 & 3 & 3 & 1.110 & 2.991 & 452 & 6,62 \\
\hline Figueiras & 22 & 641 & 75 & 16 & * & * & * & 754 & 23 & 32,78 \\
\hline Marechal Rondon & 0 & 548 & 0 & 1 & * & * & * & 549 & 551 & 1,00 \\
\hline Jarudore & 29 & 384 & 100 & 27 & * & * & * & 540 & * & * \\
\hline Taihantesu & 45 & 173 & 12 & 226 & * & * & * & 456 & 77 & 5,92 \\
\hline Chão Preto & 0 & 255 & 73 & 9 & * & * & * & 337 & 56 & 6,02 \\
\hline Ponte de Pedra & 0 & 234 & 37 & 109 & * & * & * & 380 & 427 & 0,89 \\
\hline Uirapuru & 0 & 238 & 132 & 14 & * & * & * & 384 & 18 & 21,33 \\
\hline Portal do Encantado & 166 & 880 & 126 & 41 & 35 & 107 & 740 & 1.213 & 209 & 5,80 \\
\hline Pequizal do Navurôtu & 1 & 1.111 & 367 & 58 & 12 & 0 & 1.105 & 1.537 & 69 & 22,28 \\
\hline Krenrehé & 19 & 22 & 10 & 82 & * & * & * & 133 & $*$ & * \\
\hline Maraiwatsede & 767 & 1.178 & 407 & 75 & 6 & 0 & 1.175 & 2.427 & 960 & 2,53 \\
\hline Guyraroká & 112 & 413 & 52 & 22 & * & * & * & 599 & 841 & 0,71 \\
\hline Guarani do Ribeirão & 328 & 4 & 0 & 2.560 & 0 & 0 & 3 & 2.892 & * & * \\
\hline Boa Vista & 116 & 0 & 0 & 1.110 & * & * & * & 1.226 & 87 & 14,09 \\
\hline Toldo Pinhal & 105 & 433 & 100 & 163 & * & * & * & 801 & 101 & 7,93 \\
\hline Guarani do Araça'i & 0 & 253 & 50 & 2 & * & * & * & 305 & 73 & 4,18 \\
\hline Toldo Imbu & 133 & 24 & 0 & 727 & 0 & 0 & 24 & 884 & 145 & 6,10 \\
\hline Total & 93.196 & 45.261 & 25.413 & 10.760 & 12.183 & 304 & 23.917 & 174.630 & 130.855 & 1,33 \\
\hline
\end{tabular}

* Sem informação

Obs.: Nas TIs cujos dados aparecem em fundo cinza, a população recenseada pelo IBGE superou em duas vezes ou mais a população de contagens disponibilizadas pelo ISA. 


\section{Contextualizando e interpretando os principais achados}

Este estudo, ao que nos consta, é um dos primeiros a abordar, de forma pormenorizada, os resultados da pergunta "se considera" a partir dos dados do Censo 2010 (ver também IBGE, 2012). Por isso, não há uma literatura específica sobre o tema que possa ser utilizada para fins analítico-comparativos, já que foi um quesito recentemente introduzido no recenseamento. Assim, as explicações e contextualizações apresentadas a seguir devem ser tomadas como exploratórias, sinalizando-se de antemão a necessidade de estudos adicionais sobre a temática.

A pergunta "se considera indígena", com suas alternativas de respostas "sim", "não" e "ignorado", foi inserida no questionário do Censo 2010 com vistas a estimular, para além da questão sobre "cor ou raça", declarações quanto a pertencimento indígena no caso de pessoas residentes em TIs. Segundo Pereira (2016: 425),

foi introduzida na investigação censitária porque, nas provas-piloto do Censo Demográfico 2010 realizadas nas TIs, detectou-se que um número considerável de indígenas deixou de se considerar como tal, classificando-se nas demais categorias de cor/raça, o que ocasiona perda de informações referentes à etnia e à língua falada.

Além de potencialmente importante para estimular um incremento na contagem censitária da população indígena, o fato de a pergunta somente ter sido aplicada nas TIs, por certo, resultou em diferenciais na evidenciação da presença indígena nas várias regiões do país. Com base nos dados investigados neste estudo, dispomos de escassos elementos para caracterizar esses diferenciais, mas alguns deles podem ser ao menos sugeridos. Por exemplo, nas áreas do país com maior quantidade de TIs, é provável que houve uma maior contabilização da população indígena, em virtude da aplicação das duas perguntas combinadas (sobre "cor ou raça" e "se considera"). Dessa forma, é plausível argumentar que a metodologia do Censo 2010 potencialmente levou a uma maior quantidade de respostas de pertencimento indígena nas áreas com maior volume de população indígena residindo em TIs, como na Amazônia Legal, por exemplo. Também deve ter ocorrido uma maior contabilização de declarados indígenas em áreas rurais, onde se localizam a maior parte das TIs.

É possível que a existência de critérios diferenciais para a aplicação da pergunta "se considera" possa ter levado a um decréscimo na recuperação dos quantitativos de pessoas com pertencimento indígena nos espaços geográficos localizados fora de TI. Isso porque indivíduos residentes nessas áreas que não se declararam indígenas na pergunta sobre "cor ou raça" não foram indagados em relação ao quesito "se considera". Já que a urbanização da população indígena é uma característica crescentemente observada no Brasil e em diversos outros países 
latino-americanos (Del Popolo, 2008), os efeitos diferenciais dos padrões de resposta da pergunta "se considera" devem ser tópico de cuidadosa reflexão em iniciativas censitárias futuras.

Reconhecendo-se essas potenciais consequências da aplicação da pergunta "se considera", as análises detalhadas neste estudo apontam para uma expressiva heterogeneidade segundo recortes, como situação (urbano e rural), região de residência do entrevistado, idade, alfabetização, entre outros. Inquestionavelmente, a aplicação da pergunta "se considera" levou a um importante aumento no número de indígenas registrado no Censo 2010, qual seja, de 78 mil aos 817 mil classificados na pergunta sobre "cor ou raça", o que equivale a 15,3\%. Para alguns estratos, o aumento chegou a patamares ainda mais expressivos. Por exemplo, nas TIs do Nordeste, Centro-Oeste e Sul localizadas em situação urbana, as proporções de "se considera" no cômputo total de indígenas foram superiores a 25\%, chegando a aproximadamente $45 \%$ no Nordeste. No caso das TIs em área rural, foi também no Nordeste onde se observou o maior incremento no tamanho da população indígena em decorrência da aplicação do quesito "se considera", de 18,1\% (Tabela 3).

Há dimensões metodológicas que não podem ser desconsideradas na interpretação dos resultados aqui apresentados. Através do BME e do Sidra, as bases de dados empregadas nas análises, é somente possível gerar tabulações, não se tendo acesso aos dados segundo indivíduos e respectivos pesos derivados da amostra censitária. Consequentemente, as proporções observadas nas diversas tabelas (em particular nas Tabelas 1 e 2) devem ser comparadas com cautela, haja vista que podem estar influenciadas por uma série de características sociodemográficas (diferenças de composição etária, de alfabetização e de renda, entre outras). Se dispuséssemos dos dados segundo indivíduos e respectivos pesos amostrais, seria possível realizar análises (como modelagens estatísticas) que ajustassem os resultados para as covariáveis de interesse. Recentemente, têm sido publicados estudos sobre demografia indígena, que, com base na amostra dos censos de 2000 e 2010, aplicaram análises estatísticas multivariadas (Bastos et al., 2017; Marinho et al., 2019; Santos et al., 2015), evidenciando-se que ajustes podem levar a interpretações diferentes daquelas baseadas em descrições uni e bivariadas.

Apesar dessas limitações, há diversos aspectos que se destacam a partir dos resultados derivados da pergunta "se considera", além dos já mencionados diferenciais de aumento no contingente de indígenas segundo regiões. Nesse sentido, chama atenção a elevada proporção de respostas classificadas como "ignoradas" em parcela expressiva das regiões (atingindo mais de 60\% no Norte, Sudeste e Sul urbanos), o que possivelmente sinaliza problemas na coleta dos dados durante o Censo 2010. Observou-se também que as proporções de respostas afirmativas para "se considera" foram mais elevadas em TIs localizadas em áreas rurais. Por sua vez, as análises indicam que, tanto na situação urbana quanto na rural, há variações significativas nas distribuições das respostas afirmativas para o quesito 
"se considera", segundo sexo, idade, alfabetização ou tipo de informante, o que precisaria ser confirmado por investigações quantitativas mais refinadas, contemplando ajustes para covariáveis, como já sinalizado.

Um importante achado deste estudo refere-se aos padrões de resposta para a variável relativa a pertencimento à etnia/povo indígena introduzida no Censo 2010, ao se compararem as pessoas que se classificaram como indígenas na pergunta de "cor ou raça" vis-à-vis "se considera". Como detalhado nos resultados, se a ampla maioria dos classificados como "indígenas" na pergunta sobre "cor ou raça" indicaram etnia ou povo específico (nas várias regiões, nos contextos urbanos e rurais, menos de $2 \%$ responderam "não saber"), o perfil para os indivíduos que "se consideraram" indígenas foi diferenciado. Isso porque, no caso dos que se consideraram indígenas, as frequências de "não saber" etnia ou povo foram baixas, mas se observou um volume expressivo de respostas "sem declaração" em todas as regiões, nas situações urbana e rural. Desse modo, se, por um lado, a pergunta "se considera" trouxe um aumento importante na quantidade de indígenas recenseados em 2010, por outro, chama atenção a ausência expressiva de respostas para etnia/povo no caso de indivíduos que se consideraram indígenas.

Parte significativa do esforço analítico deste capítulo se centrou na tentativa de identificação dos padrões de resposta da pergunta "se considera" segundo as TIs. Os resultados evidenciaram perfis altamente heterogêneos, dentre os quais: 1) um número reduzido de TIs concentrou uma elevada proporção dos que "se consideraram" indígenas (das 501 TIs investigadas no Censo 2010, 54, ou $11 \%$, concentraram $57,3 \%$ das 78.954 pessoas que "se consideraram" indígena; 2) parte expressiva dos indivíduos que "se consideraram indígenas" viviam em TIs nas quais a maior parte da população não se classificou como indígena na pergunta sobre "cor ou raça". Conjuntamente, esses cenários podem ser interpretados como sugestivos de que a pergunta "se considera" apresentou perfis de respostas altamente diferenciados, possivelmente associados a características específicas das TIs recenseadas, em decorrência de questões históricas, demográficas e socioculturais particulares ainda pouco conhecidas.

A complexidade associada ao segundo cenário mencionado é ilustrativa quanto à heterogeneidade dos padrões de resposta da pergunta "se considera". Por exemplo, a combinação de baixas frequências de indígenas na pergunta sobre "cor ou raça" e a elevada quantidade de "se considera sim" poderia ser observado em TIs com presença de não indígenas, em contextos de terras com invasão por não indígenas. Em uma situação como essa, classificando-se como "brancos", "pretos", "amarelos" ou "pardos" na pergunta sobre "cor ou raça", ao serem indagados se "se consideravam" indígenas, o padrão dos respondentes poderia ser de aderência ao "sim", o que pode ter decorrido de uma busca de se vincular a uma identidade "indígena" em contexto de conflito fundiário. É possível que várias das TIs com diferenças importantes entre os montantes de população indígena registrados pelo IBGE e pelo ISA, como indicado na Tabela 6, se associem a esse tipo de contexto. ${ }^{3}$ 
É possível também que este segundo cenário corresponda a TIs em que seus residentes, ainda que com pertencimento étnico indígena amplamente reconhecido, se declararam como "brancos", "amarelos", "pretos" ou "pardos" (ou seja, com ênfase na dimensão cor), mas enfatizaram que "se consideravam" indígena na pergunta adicional. Em muitas TIs do Nordeste e Sudeste, dentre outras áreas do país nas quais, ao longo dos séculos, houve uma intensa e complexa interação de indígenas com populações de origem europeia e africana, os padrões de resposta para a pergunta sobre "cor ou raça" podem ter sido influenciados por essas complexas dimensões históricas e socioantropológicas que geram padrões particulares nos contextos de classificação étnico-racial. Por exemplo, pessoas indígenas com características físicas associadas à mestiçagem com populações de origem africana ou europeia podem ter se declarado pardos e/ou pretos na pergunta de "cor ou raça", ao mesmo tempo que se "se consideraram indígenas". 4

Finalmente, uma terceira possibilidade para o segundo cenário estaria associada diretamente a questões metodológicas relacionadas aos procedimentos de coleta dos dados pelos recenseadores. Em uma análise como esta, na qual os autores não presenciaram o processo de coleta censitária, a identificação de situações com tais características é particularmente complexa. Os resultados para o quesito "se considera" para o povo Xavante é ilustrativo. Um dos autores (Ricardo Ventura Santos) desenvolve atividades de pesquisa com a população Xavante desde os anos 1990 e, a partir de sua experiência antropológica na região onde estão as TIs Xavante (leste de Mato Grosso) (Coimbra et al., 2002; Welch et al., 2013), considera o caso da TI Marechal Rondon distinto dos demais territórios Xavante no tocante ao perfil de respostas para a pergunta "se considera". Nas demais TIs Xavante, com exceção da TI Maraiwatsede, a quase totalidade dos residentes se declarou indígena na pergunta sobre "cor ou raça". Já que a TI Marechal Rondon não apresenta problemas de invasão, uma possível explicação seria o entrevistador ter errado na aplicação da pergunta. No caso de TI Maraiwatsede, é bem conhecida a grave situação de invasão que ocorria em 2010 (Ricardo G Ricardo, 2017), o que potencialmente explica a combinação de alta proporção de não indígenas na pergunta sobre "cor ou raça".

Pode-se concluir, com base no exposto, que a inclusão do quesito "se considera" teve um impacto significativo na captação de declarações de pertencimento "indígena" no Censo 2010, com destaque para as TIs localizadas em áreas urbanas. Ao mesmo tempo, foi evidenciado que, entre os que se "consideraram indígenas", uma expressiva proporção não respondeu à pergunta sobre etnia ou povo, o que levou a perdas de informação acerca desse quesito. As análises indicaram também uma heterogeneidade de padrões entre as TIs no tocante aos resultados do quesito "se considera", o que pode estar associado à presença de não indígenas que invadiram TIs, a problemas metodológicos de aplicação do quesito em alguns territórios e/ou a entendimentos específicos no contexto de certas TIs quanto às diferenças e complementariedades das perguntas acerca de "cor ou raça" e "se considera". 
Desse modo, em termos gerais, é possível afirmar que a aplicação do quesito "se considera" foi importante, mas ainda é necessário compreender melhor as dinâmicas locais/regionais que fizeram com que, em algumas TIs, tenha havido uma expressiva quantidade de pessoas que se consideraram indígenas, enquanto em outras não.

Depois de quase uma década da realização último censo, é o momento de planejar o próximo recenseamento nacional a se realizar em 2020. Tomando como referência as reflexões aqui apresentadas, julgamos que seria pertinente que, se permanecer no próximo censo a pergunta sobre cor ou raça conforme aplicada em 2010, também seja mantida a pergunta "se considera". Esse segundo quesito possibilitaria análises visando a uma melhor compreensão dos padrões de resposta em contextos geográficos específicos. Igualmente importante seria, em censos futuros, buscar-se estratégias para aplicação da pergunta "se considera" para além das TIs, já que há expressivos contingentes populacionais indígenas residindo fora dessas áreas, incluindo-se as mais diversas regiões metropolitanas do país.

Notas

* O estudo apresentado neste capítulo foi desenvolvido como parte integrante das atividades de pesquisas realizadas por Ricardo Ventura Santos com apoio do Wellcome Trust/UK (financiamento de pesquisa n. 203486/Z/16/Z) e do CNPq (processo n. 304.358/2014-2). Alessandra Traldi Simoni é doutoranda no Programa de Pós-Graduação em Demografia da Universidade Estadual de Campinas e bolsista do Wellcome Trust (UK).

1 Ao longo deste texto, de modo a não termos que repetir continuamente a pergunta, nos referimos ao quesito "Você se considera indígena?" de forma simplificada, como pergunta ou quesito "se considera indígena".

2 Para assegurar o sigilo das informações dos entrevistados, não foram disponibilizados os dados de 23 TIs no Sidra. Dessa forma, o universo de TIs com dados disponíveis é de 478.

3 No caso das TIs listadas na Tabela 6, para as quais se observaram diferenças importantes entre os volumes de população registrados pelo ISA e pelo IBGE, com maiores valores para a segunda fonte, há diversos casos amplamente documentados de situação de invasão das TIs por não indígenas, como as de Apyterewa e Cachoeira Seca, ambas no Pará (Harari, 2017; Kürten G Costa 2017).

4 Essa situação pode ser exemplificada com os resultados relativos a duas TIs localizadas no Nordeste. No caso da TI Potiguara do Monte-Mor, uma das que apresenta um maior volume de população no Nordeste, localizada na Paraíba, 5.744 pessoas não se declararam indígenas (ou seja, se classificaram como "brancas", "pretas", "amarelas" e "pardas"), das quais 4.781 se consideraram indígenas (80,0\% das que se declararam "brancas", 85,0\% das "pretas", 67,3\% das "amarelas" e 85,7\% das pardas). Em contrapartida, na TI Xukuru, 20.459 pessoas não se declararam indígenas, das quais somente 1.040 se consideraram indígenas $(4,4 \%$ das que se declararam "brancas", 7,7\% das "pretas", 6,4\% das "amarelas" e 5,3\% das "pardas". 


\section{Referências}

AZEVEDO, M. M. O Censo 2010 e os povos indígenas. In: RICARDO, B. G RICARDO, F. (Orgs.). Povos Indígenas no Brasil 2006/2010. São Paulo: Instituto Socioambiental, 2011.

BASTOS, J. L. D. et al. Sociodemographic characteristics of indigenous population according to the 2000 and 2010 Brazilian demographic censuses: a comparative approach. Cadernos de Saúde Pública, 33, supl. 1: 2017.

COIMBRA JR., C. E. A. et al. The Xavante in Transition: health, ecology, and bioantropology in Central Brazil. Michigan: University of Michigan Press; 2002.

DEL POPOLO, F. Los Pueblos Indígenas y Afrodescendientes en las Fuentes de Datos: experiencias en América Latina. Santiago: Cepal/Naciones Unidas, 2008.

DEL POPOLO, F. et al. Pueblos Indígenas y Afrodescendientes en América Latina: Dinámicas poblacionales diversas e desafios comunes. Rio de Janeiro: Alap, 2011.

FAJARDO, R. Aos 20 anos da Convenção 169 da OIT: balanço e desafios da implementação dos direitos dos povos indígenas na América Latina. In: VERDUM, R. (Org.). Povos Indígenas: constituição e reformas políticas na América Latina. Brasília: Instituto de Estudos Socioeconômicos, 2009.

HARARI, I. A Cachoeira Seca é dos Arara. In: RICARDO, B. G RICARDO, F. (Orgs.). Povos Indígenas no Brasil 2011/2016. São Paulo: Instituto Socioambiental, 2017.

KÜRTEN, F. G COSTA, C. Desintrusão da TI Apyterewa. In: RICARDO, B. G RICARDO, F. (Orgs.). Povos Indígenas no Brasil 2011/2016. São Paulo: Instituto Socioambiental, 2017.

INSTITUTO BRASILEIRO DE GEOGRAFIA E ESTATÍSTICA (IBGE). Tendências Demográficas: uma análise dos indígenas com base nos resultados da amostra dos Censos Demográficos 1991 e 2000. Rio de Janeiro: IBGE, 2005.

INSTITUTO BRASILEIRO DE GEOGRAFIA E ESTATÍSTICA (IBGE). Características Gerais dos Indígenas: resultados do universo - Censo Demográfico 2010. Rio de Janeiro: IBGE, 2012.

INSTITUTO SOCIOAMBIENTAL (ISA). De olho nas terras indígenas. Disponível em: < https:// terrasindigenas.org.br >. Acesso em: 15 mar. 2018.

LOVEMAN, M. National Colors: racial classification and the State in Latin America. Oxford: Oxford University Press, 2014.

MARINHO, G. L. et al. Classificação de cor/raça de filhos em domicílios indígenas no Brasil. Cadernos de Saúde Pública, 35(supl. 3): e00006119, 2019.

OLIVEIRA, J. P. Mensurando alteridades, estabelecendo direitos: práticas e saberes governamentais na criação de fronteiras étnicas. Dados, 55: 1.055-1.088, 2012.

OLIVEIRA, J. P. O Nascimento do Brasil e Outros Ensaios: "pacificação", regime tutelar e formação de alteridades. Rio de Janeiro: Contra Capa, 2016. 
OSÓRIO, R.G. O Sistema Classificatório de "Cor ou Raça" do IBGE. Brasília: Ipea, 2003.

PAGLIARO, H.; AZEVEDO, M. M. G SANTOS, R. V. (Orgs.). Demografia dos Povos Indígenas no Brasil. Rio de Janeiro: Editora Fiocruz, Abep, 2005.

PEREIRA, N. O. M. Avanços na captação de dados sobre a população indígena no Censo Demográfico 2010. Revista Brasileira de Estudos de População, 33(2): 423-430, 2016.

PETRUCCELli, J. L. G SABOIA, A. L. (Orgs.). Características Étnico-Raciais da População: classificações e identidades. Rio de Janeiro: IBGE, 2013. (Série Estudos e Análises, n. 2)

RICARDO, B. G RICARDO, F. (Orgs.). Povos Indígenas no Brasil 2011/2016. São Paulo: Instituto Socioambiental, 2017.

SANTOS, R. V. et al. Parity of indigenous and non-indigenous women in Brazil: does the reported number of children born depend upon who answers national census questions? PLoS One, 10(4), 2015. Disponível em: <10.1371/journal.pone.0123826>. Acesso em: 11 jul. 2019.

SANTOS, R. V. et al. The identification of the indigenous population in Brazil's official statistics, with an emphasis on demographic censuses. Statistical Journal of the IAOS, 35(1): 29-46, 2019.

UNITED NATIONS (UN). State of The World's Indigenous Peoples. New York: UN, 2009.

WELCH, J. R. et al. Na Primeira Margem do Rio: território e ecologia do povo Xavante de Wedezé. Rio de Janeiro: Museu do Índio/Funai, 2013. (Publicação avulsa, 6) 
Trajetórias, Categorias, Implicações 


\section{"Convívio e Contaminação": uma análise sócio-histórica sobre epidemias, demografia e povos indígenas na obra de Darcy Ribeiro*}

Carolina Arouca Gomes de Brito

Em 1956, o jovem antropólogo Darcy Ribeiro, então com 34 anos e ligado ao Serviço de Proteção aos Índios (SPI), publicou na revista Sociologia um emblemático artigo intitulado "Convívio e contaminação: efeitos dissociativos da depopulação provocada por epidemias em grupos indígenas". O texto é o resultado de suas observações de campo, combinadas à análise de um vasto material documental, disponível nos arquivos institucionais do SPI. O período analisado é, em grande parte, a década de 1940, porém, são citados, ao longo do estudo, materiais arquivísticos das décadas anteriores, bem como registros de campo referentes aos anos 1950.

Passadas seis décadas da publicação de "Convívio e contaminação", pode-se dizer que o texto de Ribeiro é um documento marcante não somente pela temática tratada, como também pelas fontes de dados utilizadas, procedimentos de análise empregados e, sobretudo, pelo cenário que delineia acerca do futuro dos povos indígenas no Brasil. Por essas características, o artigo se insere como peça-chave nas reflexões do antropólogo que resultaram em importantes ensaios e livro sobre a temática indígena produzidos por ele, posteriormente, em sua carreira, em particular como capítulo do livro Os Índios e a Civilização, de 1970.

Se "Convívio e contaminação" tem sido comentado nos meios antropológicos desde sua publicação há mais de meio século, foi somente em décadas recentes que pesquisadores interessados nos temas da saúde e demografia dos povos indígenas têm também chamado atenção para a importância das reflexões do autor (Coimbra Jr., 1987; Pagliaro, Azevedo G Santos, 2005). O antropólogo enfatiza que "características internas próprias às diversas sociedades tinham o potencial de influenciar a trajetória demográfica no período subsequente à crise populacional" (Pagliaro, Azevedo G Santos, 2005: 17). Ou seja, haveria uma íntima relação entre características socioculturais e comportamento demográfico. Nesse sentido, a "depopulação" provocada pelas epidemias poderia ocasionar uma profunda desorganização social das sociedades indígenas:

Isto ocorre, pois, como observa Ribeiro (1956), um sistema social só pode operar à base de um número mínimo de membros, o qual, uma vez diminuído, inviabiliza 
a vida social nos moldes tradicionais. O autor exemplifica com o caso Kaingang, cuja estrutura social tradicional fundamentada em uma divisão individual em metades exógamas, regia que os casamentos dever-se-iam dar entre membros de metades opostas. (Coimbra Jr., 1987: 28)

Apesar de "Convívio e contaminação" ser um texto amplamente conhecido em áreas como antropologia e demografia indígena, chama atenção a ausência de análises sobre o contexto da sua gênese, fontes e linhas argumentativas. O objetivo deste capítulo é situar historicamente as reflexões de Ribeiro a respeito da temática da demografia e impactos da depopulação sobre a organização social dos povos indígenas, assim como caracterizar a abordagem da saúde indígena que, à época, contribuiu para a construção de uma perspectiva de análise que concebeu as relações interétnicas como uma questão antropológica. O capítulo está estruturado em duas seções, que cobrem a trajetória acadêmica e profissional de Ribeiro no âmbito da antropologia, a gênese e conteúdos de "Convívio e contaminação". Ao final, discorre-se sobre a relevância das reflexões do antropólogo para o campo da demografia e saúde indígena no contexto contemporâneo.

\section{Trajetória de Darcy Ribeiro: breves apontamentos}

O interesse acerca do tema do contato entre índios e "brancos", índios e não índios, índios e sociedade nacional, ou índios e civilizados - todos termos utilizados nos documentos oficiais consultados para a análise de Ribeiro - mobilizou o antropólogo durante grande parte de sua trajetória acadêmica e profissional. Sua carreira teve início em 1944, quando ingressou no curso de bacharelado em ciências sociais na Escola Livre de Sociologia e Política (ELSP). Antes, porém, entre 1939 e 1943, cursou medicina na Faculdade de Medicina da Universidade de Minas Gerais. Nesse mesmo período, filiou-se ao Partido Comunista do Brasil (PCB), começou a participar ativamente do movimento estudantil do diretório central de Minas Gerais e da criação da União Nacional dos Estudantes (UNE) no Rio de Janeiro, onde passou algum tempo, em 1940. Foi nessa conjuntura que convidou algumas personalidades das ciências sociais da época para ciclos de palestras em Belo Horizonte, entre eles, Donald Pierson, sociólogo americano e professor da ELSP. Pierson, depois de passar alguns dias visitando cidades mineiras na companhia de Ribeiro, convidou-o para uma bolsa de estudos no curso de bacharelado em ciências sociais na ELSP. Ribeiro aceita o convite, deixa em definitivo o curso de medicina em Belo Horizonte e muda-se para São Paulo, onde inicia os estudos em 1944. Dois anos mais tarde, forma-se bacharel em ciências sociais. ${ }^{1}$

Ribeiro ingressou no SPI como naturalista em 1947, sob a indicação de seu mestre e orientador na ELSP, Herbert Baldus, ${ }^{2}$ permanecendo na instituição 
até 1956. Durante quase dez anos de atuação, Ribeiro realizou pesquisas etnológicas entre inúmeros grupos indígenas, dos quais se destacam: Kaiwá (1947), Terena (1947), Kadiwéu (1947-48), Ofaié (1948), Urubu-Kaapor (1949 e 1951), Kaingang (1953), Xokleng (1953), Karajá (1953), Bororo (1953), Kamauara (1953) e Kuikuru (1953). Além disso, publicou trabalhos científicos, relatórios e pareceres técnicos acerca da questão indígena, criou o Museu do Índio (1953) e desenvolveu o primeiro curso de pós-graduação em antropologia cultural no Brasil (1955-56), em parceria com a Coordenação de Aperfeiçoamento de Pessoal de Nível Superior (Capes). Ainda na década de 1950, Ribeiro participou da formulação do projeto de lei em prol da criação do Parque Indígena do Xingu (1952) e de um estudo chancelado pela Unesco (1952-53).

O programa de pesquisas coordenado pela Unesco, do qual Ribeiro fez parte, foi concebido como uma expansão do Projeto Unesco de Relações Raciais, desenvolvido no Brasil entre 1950 e 1951 (Maio, 1999). No âmbito desse novo programa de pesquisas, ${ }^{3}$ o departamento de ciências sociais da agência coordenou e financiou estudos em seis países (Brasil, Antilhas Francesas, Estados Unidos, Alemanha, Iugoslávia e México). ${ }^{4}$ Essas investigações tinham por objetivo analisar variados grupos considerados à época minoritários em seus ambientes sociais específicos, a fim de compor um quadro comparativo que valorizasse aspectos "econômicos, sociais, educacionais, políticos e mesmo jurídicos dessas populações" (Wagley G Harris, 1958: X-XI). Os pesquisadores deveriam elaborar relatórios baseados nas observações já realizadas em torno da temática das relações raciais, a fim de ampliar a análise com base em uma abordagem comparativa no âmbito da antropologia social, sobretudo em torno das temáticas relacionadas às chamadas minorias.

Para desenvolver seu estudo para a Unesco, Ribeiro mobilizou uma extensa bibliografia sobre a temática indígena, combinada à análise de relatórios oficiais do SPI de períodos anteriores à sua atuação, além de pesquisas de campo com o objetivo de observar as relações estabelecidas entre índios e brancos, sobretudo aqueles que residiam nos arredores de postos indígenas. $\mathrm{O}$ trabalho, portanto, uniu registros de pesquisas de experiências anteriores com os índios Guarani, Terena, Ofaié e Kadiwéu do sul de Mato Grosso, os Tembé, Guajajara e Urubu, dos vales do Pinaré e Gurupi no Pará e no Maranhão; além das análises inéditas sobre os grupos Borôro, Karajá, Kaingang e Xokleng. Segundo Ribeiro, em seu relatório de atividades para a Seção de Estudos (SE) do SPI: "Como estes grupos representam as principais variantes nas situações de contato entre índios e brancos no Brasil, nos foi possível delinear um quadro realístico das condições de vida dos índios do Brasil em geral e de seu lugar na estrutura social" (SPI, 1954: 3).

A questão central da análise de Ribeiro sobre as relações entre índios e brancos no Brasil contemplava, portanto, temas como: a ruptura social dos povos decorrente da interação com não indígenas (em particular devido às epidemias), 
a ineficiência do SPI, as questões da terra, demografia e saúde indígena no país. Foi nesse contexto que o antropólogo estruturou os argumentos apresentados em "Convívio e contaminação".

\section{Gênese e versões de "Convívio e contaminação"}

Anteriormente, em 1949, por ocasião de suas pesquisas entre os UrubuKaapor, Ribeiro já aborda a questão sanitária com base na relação direta entre doença e redução demográfica de grupos indígenas. Essa perspectiva fica clara em seus diários de campo, onde estão registrados inúmeros casos de epidemias de sarampo entre os índios da região, a ineficiência da assistência sanitária oferecida pelo SPI e as consequências marcantes da redução demográfica na estrutura social dos grupos indígenas. Nas anotações do dia 21 de dezembro de 1949, Ribeiro (1996b: 80-81) escreve, ${ }^{5}$

As outras aldeias estão também atacadas pela epidemia. Talvez seja o fim do Urubu ou, ao menos, um golpe tão sério que a resistência que acaso opunham à submissão e degenerescência será destruída. O posto não tem nenhum recurso para atendê-los e, se não estivéssemos aqui, provavelmente nem se lembrariam de apelar para a inspetoria, pedindo providências urgentes. Os veriam morrer, lamentando muito de braços cruzados. É um crime que o SPI, depois de vinte anos de pacificação, não tenha feito vacinar esses índios contra doenças tão comuns, de imunização tão fácil e barata e tão terrivelmente fatais para eles.

No relatório oficial sobre o primeiro período entre os Urubu-Kaapor, entregue à diretoria do SPI em 1950, Ribeiro expõe de forma clara sua hipótese acerca da relação entre doenças, carências assistenciais e desestruturação social de grupos indígenas:

Na região percorrida por mim, a situação era a mesma. Do Posto Felipe Camarão visitei a aldeia Tembé-Urubu (...) e a aldeia Urubu de Kuaxi - Puru, ambas atacadas pela epidemia, desertas, os índios na mata, fugindo do sarampo e já atacados por eles. Daí seguimos para aldeia Major (...). Também aí todos doentes, na mata, e o mais deplorável é que morriam já não da doença, mas de fome. Suas enormes roças de mandioca por que passávamos de nada lhes serviam. Não havia qualquer pessoa capaz de andar e fazer farinha, mesmo água lhes faltava e sem forças para armar "Tapiría", muitos ardiam de febre ao relento, sob a chuva, em redes imundas. Crianças abandonadas ao chão comiam terra, queimavam-se ao fogo que se esforçavam por manter aceso debaixo da rede dos pais. Aí ficamos dois dias ajudando-os no que podíamos: fazendo mingau de bananas verdes para os 
sãos, cozinhando sopas pré-fabricadas para os mais doentes, ajudando os Tapiría, fazendo fogo e apanhando água para eles (...). O mais grave é que também no posto a fome matava tanto quanto a doença. (SPI, 1950: 3)

A narrativa de Ribeiro enfatiza desdobramentos das epidemias que ultrapassavam a redução demográfica, quais sejam, quadros de profunda desintegração social, além de deixar clara a incapacidade do SPI na promoção da assistência ao índio naquele momento. As consequências, ou os "efeitos dissociativos de depopulação", como ele denominou, continuariam operando mesmo depois de passadas as primeiras epidemias. Com esse argumento central é que Ribeiro desenvolve "Convívio e contaminação".

A primeira versão do texto foi preparada para uma apresentação na II Reunião Brasileira de Antropologia, que ocorreu em 1955, na Bahia. 6 Um ano depois, em 1956, o material foi revisto e publicado na revista Sociologia, com o subtítulo: "Efeitos dissociativos da depopulação provocada por epidemias em grupos indígenas". ${ }^{7}$ Aproximadamente 15 anos depois, em 1970, foi publicado, sem o subtítulo, como um dos capítulos do livro Os Índios e a Civilização.

As versões do texto de Ribeiro não apresentam grandes diferenças de forma ou de conteúdo e seguem um idêntico ponto de vista argumentativo. A questão indígena é abordada a partir de suas principais questões à época, que se referiam ao contato entre índios e brancos, à deficiência do SPI no âmbito da assistência ao índio e aos efeitos socioculturais das epidemias e consequente queda demográfica. As publicações que se seguiram à primeira versão apresentam informações complementares, sobretudo dados estatísticos (tabelas, pirâmides e gráficos) e algumas supressões de pequenos trechos/palavras. Numa tentativa de exegese do texto de Ribeiro, pontuo as nuances do texto, com base na análise das publicações nas décadas de 1950 e 1970.

A primeira versão é a mais concisa, com apenas 28 páginas e quatro quadros estatísticos. A segunda e a terceira, quase sem diferenças na estrutura do texto, são compostas por 44 páginas e 11 quadros/gráficos estatísticos.

A segunda versão, divulgada na revista Sociologia, em 1956, é a mais completa se comparada à primeira, sobretudo em relação à sistematização dos dados. A bibliografia utilizada, quase toda datada das décadas de 1930, 1940 e 1950, é complementada com dados estatísticos de estudos e observações do início do século XX, realizados por médicos e antropólogos vinculados ao SPI, especialmente no contexto de epidemias desencadeadas por ocasião dos primeiros contatos de povos indígenas isolados com não indígenas.

O objetivo central de seu trabalho, segundo o próprio Ribeiro (1953: 3), era "estudar as doenças que foram levadas aos índios através do contato com a civilização e os efeitos dissociativos da depopulação que elas provocaram". A esse propósito, descrito nas duas primeiras versões, é somada mais uma frase no texto 
de 1970: "e do debilitamento por elas provocado" (Ribeiro, 1970: 273, destaque meu). A clara intenção do autor era explorar a ocorrência de epidemias entre os indígenas como mais um dos fatores desagregadores gerados pelo contato entre índios e brancos até aquele momento.

Nos primeiros parágrafos do texto, Ribeiro recorre à imagem da vulnerabilidade das populações indígenas aos "vírus e bacilos" trazidos pelos "brancos": "A história da relação entre índios e brancos no Brasil ensina que as armas de conquista foram alguns apetites e ideias, um equipamento mais eficiente de ação sobre a natureza, bacilos e vírus, sobretudo vírus" (Ribeiro, 1956: 3, destaque meu).

Ribeiro enuncia, em seguida, que não irá discutir os aspectos biológicos da questão e segue ratificando o efeito nocivo das doenças levadas aos índios pelo contato com a civilização: "Até hoje não foi rigorosamente documentada qualquer moléstia originalmente indígena que passasse à população brasileira, a não ser pequenas micoses (...). É vultoso, porém, o número de entidades mórbidas levadas aos índios (Ribeiro, 1956: 4).

A bibliografia, as fontes oficiais do SPI e as pesquisas de campo utilizadas na composição desse estudo revelaram que as doenças que causaram maior letalidade entre os índios ao longo do tempo foram a gripe e o sarampo. Ribeiro (1956) chega a afirmar que uma das primeiras palavras que as várias tribos pacificadas aprenderam dos civilizados (ou que criaram após o primeiro contato) foram para designar a gripe. Entre os Urubu, a palavra usada era catar ou catarro, entre os Kaingang, cofuro (tosse, espirro).

Também o sarampo assolou grupos indígenas inteiros desde os primeiros registros de contato entre índios e brancos, de acordo com a documentação disponível nos registros do SPI, à qual Ribeiro teve acesso para compor sua análise. O mesmo ocorreu com os Kaingang paulistas em 1913, segundo relato de Horta Barboza. ${ }^{8}$ Em 1950, em sua viagem aos aldeamentos Urubu, Ribeiro relatou também um grave surto de sarampo, que havia atingido os índios antes mesmo da chegada de sua equipe. Muitos indígenas fugiram das aldeias e montavam acampamentos nas matas, imaginando fugir também da doença e de seus efeitos. Porém, alguns já estavam infectados e "morriam de fome e de sede, tanto quanto da doença" (Ribeiro, 1956: 8).

Diante desse quadro, Ribeiro refuta o que chamou de "explicação corrente" para o alto índice de mortes provocadas pelo sarampo, pela gripe e outras doenças respiratórias, que estava vinculada à noção de que os indígenas não teriam conhecimento das práticas higiênicas, ou não respeitavam as prescrições de dieta e medicamentos da "nossa medicina":

Uma explicação corrente para esta virulência tem sido o desconhecimento de práticas higiênicas por parte dos índios e seu costume de refrescarem-se nos rios quando ardiam em febre. Aduz-se, ainda, a dificuldade de fazê-los submeterem-se 
a dietas prescritas para estas doenças ou medicarem-se de acordo com as regras de nossa medicina. Tudo isso, entretanto, não explica tão alta letalidade e ainda mais quando se considera que a antiga farmacopeia de mesinhas e a higiene praticada em comunidades rurais hoje não apresentam grande superioridade sobre a dos índios. (Ribeiro, 1956: 5-6)

Ribeiro já abordara o tema da proximidade cultural entre índios e sertanejos, sobretudo no âmbito das dinâmicas alimentares e sanitárias, em outros registros, como em seu relatório ao SPI no ano de 1950:

Compreendendo por civilização o conjunto de técnicas das sociedades industriais modernas, aquela população [população indígena da região do Vale do Gurupi, entre os estados do Pará e do Maranhão] tem tanto de civilizada quanto indígena. Aliás, tivemos ocasião de observar que seu [dos sertanejos] equipamento cultural é, no essencial, idêntico aos dos índios; através de técnicas indígenas é que se encastoam naquelas barrancas procurando tirar dela a subsistência. Vi os negros caçando e pescando com arcos e flechas adquiridos aos índios, imigrantes estrangeiros (círios, portugueses, inglês e um húngaro) tendo como alimentação básica a farinha de mandioca, puba, espremida no tipiti indígena; as casas de pau a pique barreado cobertas de palhas de pindó ou açaí são as mesmas que as atuais habitações indígenas; suas poucas roupas, os pés descalços, o ventre inchado de verminose, a malária, a tuberculose, a avitaminose, são também igualmente participadas. (SPI, 1950: 3)

Na perspectiva defendida por Ribeiro em "Convívio e contaminação", o primeiro contato com as doenças dos "civilizados" era em geral letal aos índios, que só apresentavam possibilidades de recuperação após terem desenvolvido resistência a tais doenças. Para corroborar esse argumento, Ribeiro usa como exemplo uma epidemia de varicela entre os Bororo em 1953, na qual cerca de 80\% do grupo de 120 indígenas foram atingidos e somente oito indivíduos morreram. Segundo o antropólogo, essa baixa letalidade não poderia ser explicada por uma assistência mais eficiente do SPI aos indígenas (com vacinas), posto que o serviço não tinha um plano de atenção sanitária em suas primeiras décadas de atuação, mas sim por uma "resistência adquirida ou desenvolvida contra essas moléstias". Ribeiro (1956: 8- 9) prossegue: "A explicação se baseia no fato, confirmado por vasta documentação de que em populações virgens de contágio certas doenças alcançam um alto grau de letalidade, no primeiro ataque, caindo depois progressivamente". O autor apresenta ainda outra variável para a alta mortalidade entre os indígenas acometidos por doenças infecciosas ao longo do tempo que mais uma vez difere das justificativas referentes à vulnerabilidade biológica ou à falta de imunidade dessas populações. Para Ribeiro, a causa fundamental dessas mortes estaria na "paralisação abrupta das atividades produtivas", ou seja, a debilidade causada pela doença impossibi- 
litaria o grupo inteiro de cuidar das demandas para o provimento de alimentos necessários. Essa questão se tornaria ainda mais grave, pois as "tribos indígenas" não contariam "com um sistema de estocagem de alimentos que permitisse fazer face a tais eventualidades" (Ribeiro, 1956: 9, destaque do original).

Ribeiro segue discutindo trabalhos realizados no âmbito do SPI em torno da temática indígena, especialmente os produzidos na década de 1950 e que compõem o relatório oficial do SPI de 1954, tais como: a análise do médico sanitarista Amaury Sadock de Freitas Filho sobre o estado sanitário dos índios Xavante, no Mato Grosso, e o levantamento do também médico do SPI naquele momento, Noel Nutels, acerca da ocorrência de tuberculose entre os índios da região do Xingu.

A partir da leitura desses relatórios e das suas observações em campo, Ribeiro compõe um diagnóstico acerca da questão sanitária dos grupos indígenas de uma perspectiva ampla, ou seja, a doença, o contágio e os processos de cura são problematizados correlacionando-os às transformações sociais, culturais e políticas ocorridas no âmbito da assistência ao índio no Brasil, sobretudo pelo SPI. A garantia à saúde do indígena, para o antropólogo, deveria ser acompanhada de uma série de estratégias políticas em torno da questão indígena nacional, como a garantia de terras e o direito à produção agrícola, por exemplo, somada a uma assistência sanitária organizada que compreendesse não somente médicos e medicamentos, mas uma rede de acompanhamento nutricional e educacional voltada para a estrutura sociocultural dos índios. Esse ponto de vista fica claro no trecho em que o autor se refere ao relatório de Leão da Mota sobre a região do Xingu:

Embora se tenham usado os principais recursos da medicina moderna, como a penicilina, a estreptomicina e outros, os médicos assistentes acreditam que o principal fator para a recuperação dos enfermos foi o fornecimento de alimentação regular, o que não puderam ter os grupos não assistidos. Vê-se, pois, a precariedade do equipamento de garantia da subsistência torna estes grupos mais vulneráveis aos efeitos das epidemias. (Ribeiro, 1956: 10)

A precariedade da assistência aos povos indígenas é também relacionada por Ribeiro como um fator importante para o aumento da letalidade de doenças infectocontagiosas, como o sarampo e a gripe, quando atingem grupos indígenas.

Ainda sobre a questão nutricional das populações atingidas por epidemias, Ribeiro recorre ao relatório do médico sanitarista que prestava serviços ao SPI na década de 1950, Amaury Sadock de Freitas Filho, que apresentava um quadro positivo sobre o estado nutricional dos Xavante nesse período, sobretudo porque ainda estariam no início do "convívio com civilizados" e que, por isso, conservariam seus "hábitos alimentares tradicionais" (Ribeiro, 1956: 13).

O antropólogo continua sua argumentação citando outro relatório, o do médico também vinculado ao SPI Leão da Motta, de 1955, sobre um estudo 
sanitário realizado entre os Kaiwá e os Terena do Sul do Mato Grosso, que mantinham "contatos seculares com civilizados". A situação nutricional desses grupos, diferentemente da dos Xavante, era descrita como negativa: 60\% dos indígenas apresentavam sinais clínicos de anemia e subnutrição (SPI, 1955).

Ribeiro conclui sua tese sobre a relação entre estado nutricional, contato entre índios e brancos, e aumento da letalidade das epidemias nos grupos indígenas com base no que ele chamou de "moléstias carenciais":

As moléstias carenciais que não ocorrem, ao que saibamos, em populações isoladas, são frequentes nos grupos em convívio com civilizados e se prendem à adoção de novos hábitos alimentares, bem como ao abandono das antigas fontes de suprimento que lhes garantiam o vigor físico. À medida que se intensificam os contatos e os índios vão adotando as práticas e os preconceitos alimentares das populações rurais surgem os distúrbios motores, as lesões oculares e outras, que parecem devidas a insuficiências alimentares. (Ribeiro, 1956: 12)

Na segunda parte de "Convívio e contaminação", Ribeiro apresenta dados estatísticos que visam a demonstrar a hipótese da progressiva redução populacional de grupos indígenas causada por doenças introduzidas pelos brancos no processo do contato. Parte do material é exposta na forma de gráficos e quadros que comparam a composição etária das populações investigadas (Figura 1). Não é indicado no texto o período de cada levantamento, porém subentende-se que as informações demográficas são oriundas dos arquivos do SPI, que foram investigados pelo autor para fundamentar seu argumento. Possivelmente se referem a dados coletados entre as décadas de 1920 e 1950.

Os dados apresentados na Figura 1 referem-se à "estrutura demográfica" de "tribos", que, segundo Ribeiro (1956: 17), "diferem no grau de contato que mantêm com civilizados e também em suas formas de adaptação ecológica". Contudo, o antropólogo enfatiza que tais dados não deveriam ser tomados como representativos das características das populações indígenas em geral, mas sim daquelas "tribos" específicas, e nos respectivos contextos no quais foram colhidos. Desse modo, as informações apresentadas teriam "valor de instantâneos da vida tribal no momento em que foram contadas, ${ }^{9}$ proporcionando visualizações mais realísticas do que se poderia obter, por qualquer outra técnica, da estrutura demográfica tribal num dado momento" (Ribeiro, 1956: 20).

A comparação das composições demográficas dos 13 grupos indígenas analisados, segundo o autor, revelariam três "padrões estruturais distintos": o primeiro padrão representaria uma baixa longevidade entre os indígenas, sobretudo pela reduzida porcentagem de indivíduos maiores de 40 anos; o segundo, um equilíbrio etário proporcional, com altas porcentagens de indivíduos com mais de 9 anos de idade, o que para Ribeiro, caracterizava o grupo apto ao crescimento; 
por fim, o terceiro padrão identificaria "predomínio de indivíduos maduros", o que revelaria uma população estabilizada.

Figura 1 - Série comparativa da composição etária percentual da população de treze tribos indígenas

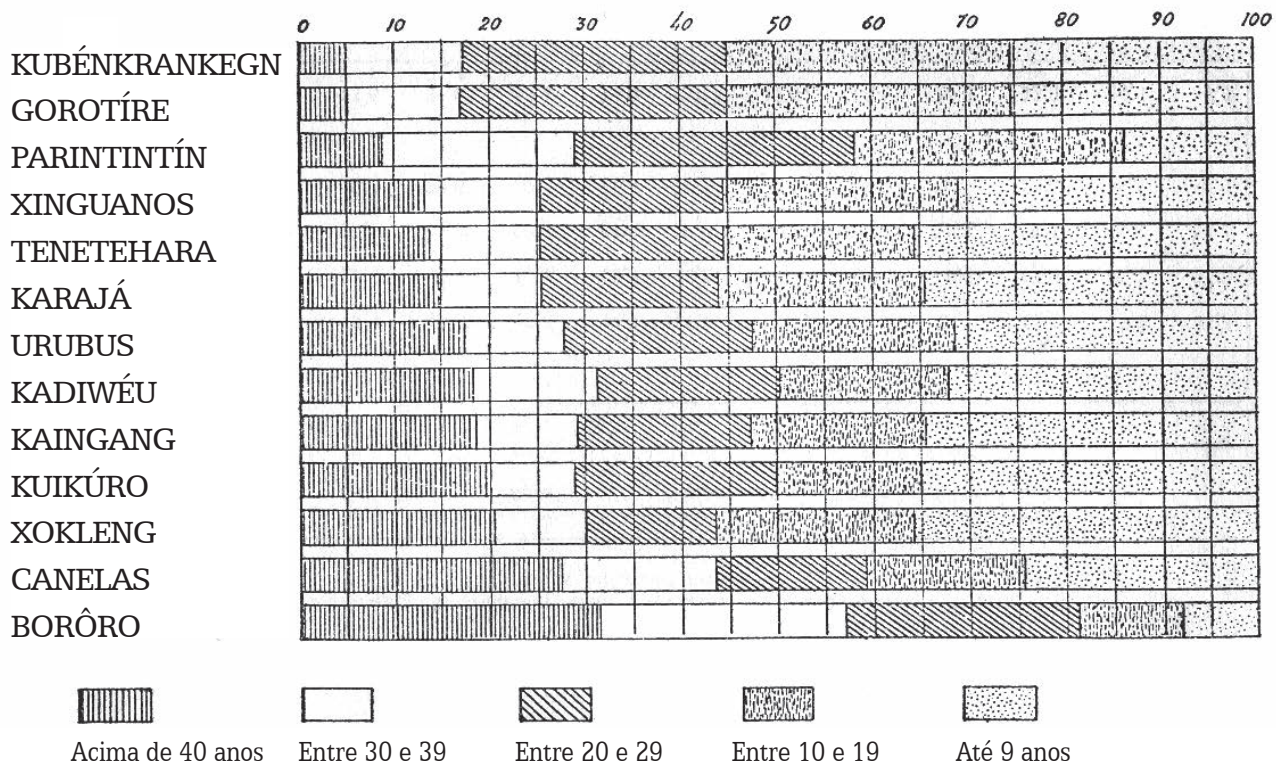

Fonte: "Convívio e contaminação" (Ribeiro 1956: 19).

O segundo, o terceiro e o quarto quadros referem-se à distribuição por sexo e por idade dos grupos indígenas analisados. Reproduzo os respectivos títulos: Quadro 2: "Distribuição por sexo e idade da população Gorotire (1952), Kuben-kran-kegn (1952), de um grupo Parintintin (1928), e de dois grupos Bororo (1932)"; Quadro 3: "Distribuição por sexo e idade das populações Kaingang de São Paulo (1953), Xokleng de Santa Catarina (1953), Urubu (1950) e Kuikuru (1954)" e Quadro 4: "Distribuição por sexo e idade das populações Kadwéu do sul de Mato Grosso, recenseadas pelo autor em 1948; Karajá do Posto Indígena Getúlio Vargas e da Aldeia Fontoura, Goiás, em 1952, segundo dados colhidos por Hugo Mariano Flores; das aldeias Tenetehara de Altamira, Uchoa, Farinha, Mundo Novo, Colônia, S. José e Coco do município de Barra do Corda, no Maranhão, e das aldeias Canelas do Porquinho e Rapousa, no mesmo município, segundo censo realizado pelo SPI em 1939". Cada um desses três quadros é representado também por uma pirâmide demográfica. Além disso, ao longo segunda parte do "Convívio e contaminação", são dispostos outros quadros estatísticos, sem títulos, a saber: "Quantidade de filhos por mulher, por faixa etária" (dados recolhidos entre os Bororo em 1934 por Herbert Baldus), "Mortalidade infantil indígena" e "Número médio de crianças 
por mulher" (ambos derivados de pesquisas realizadas pelo médico do SPI João Seroa da Motta entre os Kuikuru em 1954).

A dimensão da quantificação de dados demográficos por Ribeiro possivelmente se associa à dupla atuação do autor, quais sejam, a de antropólogo especializado e a de funcionário do Estado, o que justificaria a escolha pela representatividade dos dados burocráticos em torno da questão demográfica. A isso também se associa a metodologia de análise escolhida por Ribeiro, que articulou dados documentais (relatórios e inquéritos realizados por médicos do SPI) às suas pesquisas de campo, a fim de compor um quadro da situação da saúde e da demografia indígena no período.

Ao longo de "Convívio e contaminação", o autor elencou algumas "condições peculiares" que teriam determinado, à época, o maior ou o menor impacto das epidemias e/ou do contato entre índios e brancos. Entre esses fatores estariam: lutas em defesa dos territórios, "convívio pacífico" ou não com a sociedade nacional, "práticas abortivas" e "infanticídio". Ao mesmo tempo que Ribeiro faz comentários sobre a representatividade desses levantamentos, ele os utiliza para caracterizar a situação das populações indígenas em perspectiva histórica, sobretudo em relação à dinâmica do contato entre índios e brancos:

Estes dados, embora precários, indicam que, após as reduções maciças que se seguem aos primeiros contatos, alguns grupos indígenas alcançam uma acomodação que lhes permite sobreviver, enquanto outros continuam diminuindo até o desaparecimento. Que fatores influem no processo, condenando algumas tribos ao extermínio e permitindo a outras retomar um certo equilíbrio demográfico que lhes assegure a sobrevivência? Tantos elementos circunstanciais podem atuar para modificar o processo em cada caso concreto, que só historicamente ele poderia ser explicado. Entretanto, pelo menos em alguns casos, é cabível explicar a sobrevivência ou o extermínio pela atuação de condições estruturais e funcionais anteriores ao contato. O estudo destas condições impõe, inicialmente, a análise do comportamento das estruturas demográficas em face dos sucessos que se seguem ao convívio pacífico, particularmente com referência aos fatores de depopulação. (Ribeiro, 1956: 17)

Ribeiro intentava, com essa análise, compreender a dinâmica social daqueles grupos, principalmente a partir do impacto das epidemias: "A análise das estruturas demográficas tribais nos ensina, pois, que certas condições socioculturais podem predispor uma população ao extermínio por efeito do contágio de epidemias" (Ribeiro, 1956: 37).

Salvo as distinções estruturais (fertilidade, natalidade, mortalidade) e/ou ambientais que configuram cada grupo indígena, a conclusão de Ribeiro é que, quanto maior o isolamento do grupo, maiores são as possibilidades de sobrevivência, já que a principal causa da depopulação dos grupos indígenas tem sido as doenças "levadas aos índios através do contato com a civilização" (Ribeiro, 1956: 3). 
A parte final do texto refere-se aos efeitos dissociativos da depopulação, pois, segundo o autor, mesmo passados os períodos das epidemias, era possível perceber as consequências, no plano sociocultural, nos grupos indígenas atingidos. Nessa seção, Ribeiro baseia-se não só em suas análises de campo, mas também nos trabalhos de Gustavo Dobt (1939) e Arrojado Lisboa (1935), acerca dos grupos indígenas da região do Gurupi no início do século, e também de Charles Wagley (1942), sobre os Tapirapé. Este último antropólogo analisou os registros demográficos dos Tapirapé do Brasil Central, desde o primeiro contato com o branco em 1909 até 1935, e constatou que, após sucessivas epidemias de gripe, febre amarela e varíola, a população indígena dessa região experimentou uma redução da ordem de 85\% de seu contingente original. Wagley chamou atenção para as profundas alterações nas relações sociais e culturais do referido grupo indígena, que teriam levado à desorganização de segmentos familiares, econômicos, cerimoniais e mesmo matrimoniais. Sobre os dados analisados por Wagley entre os Tapirapé, Ribeiro (1956: 40) afirma:

Como se vê a depopulação têm consequências específicas sobre o funcionamento da vida social, independente das mudanças culturais ocasionadas pela adoção de novos elementos, como ocorre no processo de aculturação. É que um sistema social qualquer, mesmo o mais simples, só pode operar à base de um número mínimo de membros, o qual, uma vez diminuído, impossibilita a vida social, dentro dos moldes tradicionais.

Ribeiro utiliza ainda outros exemplos de desestruturação social de grupos indígenas, sobretudo em torno da dinâmica social, proveniente da queda populacional relacionada às epidemias enfrentadas ao longo do tempo. Sobre os dados arrolados dos vários segmentos da organização social Kaingang, o autor afirma que "poucos anos depois da pacificação, alguns deles estavam muito reduzidos e outros haviam desaparecido completamente". Outra consequência direta da alta mortalidade de índios em idade adulta seria a "orfandade de um grande número de crianças" (Ribeiro, 1956: 41, 42) e uma consequente desorganização familiar e social.

O tema do contato entre índios e brancos figurou como um dos principais pontos de reflexão antropológica e institucional na trajetória do antropólogo no âmbito do SPI, e não somente em "Convívio e contaminação". A natureza desse contato, na perspectiva teórica e também metodológica de Ribeiro, vinculava-se, em geral, aos comprometimentos sociais, demográficos e sanitários a que estariam sujeitos, sobretudo, os indígenas. Desse modo, o problema sanitário era abordado pelo autor como um dos fatores de desestabilização social e cultural de grupos indígenas, e não estava restrito à questão biológica ou à relação saúde e doença apenas.

Importa salientar, ainda, que os recursos da medicina moderna apontados por Ribeiro e citados no relatório de Leão da Mota não alcançavam grande número de grupos indígenas no território brasileiro. A assistência médica oferecida pelo 
SPI, ao longo de toda a sua atuação institucional (1910-1967), não foi regular e se mostrou pouco efetiva para enfrentar as devastadoras epidemias que atingiram essas populações. Conforme observaram Brito e Lima (2013: 59), "a saúde indígena era, no período citado, considerada como inoperante, ineficiente e, por vezes, ausente". Diante desse argumento, mais forte se tornava o discurso de Ribeiro sobre uma assistência sanitária integrada que deveria ser oferecida ao indígena brasileiro. Não somente em "Convívio e contaminação", mas em grande parte de sua produção científica e institucional em torno da temática indígena, o autor problematizou a questão do contato das populações indígenas com a sociedade nacional envolvente e suas profundas e duradouras consequências. Várias décadas depois de ter se dedicado à etnologia indígena, continuou a se manifestar sobre a questão da forma eloquente que marcou o seu estilo:

um indígena que escrevesse esta história poderia dizer que a marcha da Europa sobre o mundo foi uma marcha de um povo pestilento que levava consigo dezenas de enfermidades antes desconhecidas - como a tuberculose, a varíola, a sífilis, o sarampo, a gripe - e que para cada povo que não havia experimentado o contágio anterior representou uma mortandade trágica (...). Para o indígena, o encontro com o europeu é o encontro com um povo pestilento, que apodrece seus corpos, faz cair seus dentes, arder com a febre. Os restos humanos que sobram dessas epidemias são ainda submetidos a condições de vida tão miseráveis e a uma exploração tão inclemente que acaba por liquidá-los. (Ribeiro, 2007: 54-56)

\section{Considerações finais}

No conhecido Handbook of South American Indians, organizado por Julian Steward e publicado em 1949, o antropólogo norte-americano apresenta estimativas para o tamanho da população indígena da América do Sul no século XVI, por ocasião da chegada dos primeiros colonizadores europeus, e a subsequente redução demográfica. Como observam Pagliaro, Azevedo e Santos (2005: 16),

ressaltando as dificuldades metodológicas envolvidas, Steward chegou a um valor de aproximadamente 9,1 milhões de indígenas na América do Sul em 1500, que teria decrescido para 6,9 milhões em 1940. Doenças, guerras, perseguições e rupturas econômicas e sociais são apontadas como as principais causas responsáveis pela redução populacional. Para a área relativa ao Brasil, o autor estimou que era habitada por 1,1 milhão de indígenas em 1500, tendo decrescido para 500 mil em 1940.

O tema da redução demográfica da população indígena já chamava a atenção de antropólogos em meados do século XX. Além de tentativas de estimar 
as variações populacionais, em face das consequências das interações com os colonizadores em escala temporal mais ampla, estudiosos comumente descreviam, em suas etnografias, os profundos efeitos decorrentes da redução populacional em decorrência de epidemias no âmbito da organização social (Caspar, 1957; Wagley, 1942; Oliveira, 1958; Mussolini, 1946).

É nesse cenário histórico e antropológico que se insere a publicação de "Convívio e contaminação" na década de 1950. Por um lado, Ribeiro abordou um tema que estava sendo frequentemente registrado em estudos etnográficos e em observações de funcionários do SPI em diversas regiões do país. Por outro, inovou não somente por enfatizar a depopulação decorrente das epidemias como ponto central do processo de desorganização social e econômica das populações indígenas, mas também por apresentar uma argumentação baseada na situação de um amplo conjunto de sociedades. Se os estudos etnográficos sobre o tema tendiam a abordar sociedades indígenas específicas (Caspar, 1957; Wagley, 1942; Oliveira, 1958; Mussolini, 1946), Ribeiro, como funcionário do SPI, teve acesso a dados etnográficos e quantitativos que permitiram delinear um cenário comparativamente mais abrangente. Considerada retrospectivamente, a análise expressa em "Convívio e contaminação" era fortemente marcada por uma perspectiva pessimista, prenunciando o desaparecimento de inúmeros grupos indígenas do país e as dificuldades das sociedades indígenas de sobreviverem como entidades socioculturais diferenciadas.

Como se vê, é catastrófico o vulto da redução populacional sofrida por estes grupos indígenas após os primeiros contatos, ocasionada principalmente pela contaminação pelos agentes mórbidos referidos. Tudo leva a crer que o mesmo tenha ocorrido em todas as tribos, em todos os tempos. (Ribeiro, 1956: 16)

O pessimismo de Ribeiro diante das perspectivas de sobrevivência da população indígena no Brasil, em meados do século XX, não lhe era exclusivo; pelo contrário, era disseminado entre antropólogos, historiadores e indigenistas (Hemming, 2003). Vale destacar, contudo, que, anos mais tarde, o antropólogo reconsiderou sua visão sobre o tema: na década de 1970, sobretudo, a partir dos conceitos de integração e de transfiguração étnica, apresentados de forma completa na obra Os Índios e a Civilização, em que enfatizou as possibilidades e/ou os níveis do contato entre índios e brancos na sociedade nacional. Ressalta-se que, a questão central de sua interpretação já estava presente em seus trabalhos na década de 1950 e, potencialmente, no argumento de "Convívio e contaminação". Talvez por isso, o texto elaborado e reeditado na década de 1950 tenha ganhado espaço na reelaboração teórica na década de 1970, não mais como um retrato de um período, e sim como um indício empírico de sua análise em torno da dinâmica do contato entre índios e brancos no país de uma perspectiva histórica. 
Também em 1988, no prefácio do livro Os Índios e o Brasil, do antropólogo Mércio Gomes, Ribeiro afirmou que a maioria dos grupos indígenas brasileiros estaria em "franco crescimento demográfico". Nos anos 1990, no prefácio à sétima edição de Os Índios e a Civilização, o autor reafirmou: "A boa notícia que tenho para os novos leitores deste livro é que os índios estão aumentando de número. Há trinta anos atrás, eles se reduziram a cerca de 100 mil. Hoje se acercam dos 300 mil e vão aumentar mais" (Ribeiro, 1996a: 1).

Ao longo dos últimos anos, a temática da demografia dos povos indígenas no Brasil tem recebido renovada atenção por parte de antropólogos, demógrafos e pesquisadores da área da saúde (Azevedo, Simoni G Cruz, 2017; Campos G Estanislau, 2016; IBGE, 2012; Pagliaro, Azevedo G Santos, 2005; Santos, 2016). Em larga medida, isso tem ocorrido porque os dados sobre as populações indígenas, no contexto que se seguiu à redemocratização do país, exemplificado pela Constituição Federal de 1988, passaram a ser produzidos e sistematizados pelo Estado. Além dos diversos trabalhos em antropologia demográfica, com foco em comunidades específicas, cujas análises apontam para importantes níveis de crescimento populacional (Azevedo, Simoni G Cruz, 2017; IBGE, 2012; Santos G Teixeira, 2011), os dados dos três mais recentes censos nacionais (1991, 2000 e 2010) contribuíram para dar maior visibilidade demográfica e estatística da população indígena. Nesse novo cenário, no qual o crescimento demográfico da população indígena é evidente, ao mesmo tempo que a violência contra os povos indígenas persiste, mesmo que com diferentes contornos (Carneiro da Cunha et al., 2017), revisitar a obra de Ribeiro, e "Convívio e contaminação" em particular, ajuda-nos compreender a complexa trajetória das reflexões sobre as interfaces entre história, antropologia, saúde e demografia indígena no Brasil desde meados do século XX. 
* Esse texto é parte do terceiro capítulo da minha tese de doutorado defendida no Programa de História das Ciências e da Saúde da Casa de Oswaldo Cruz da Fundação Oswaldo Cruz (Brito, 2017).

1 Esses dados foram recuperados nos arquivos do Memorial Darcy Ribeiro (Universidade de Brasília) e também da Fundação Escola Livre de Sociologia e Política de São Paulo (FELSP).

2 Herbert Baldus foi um antropólogo alemão (1899-1970) que atuou no Brasil entre 1927 e 1970 e foi um importante interlocutor de Darcy Ribeiro, desde a ELSP.

3 Refiro-me, com o termo "novo programa de pesquisas", aos estudos realizados posteriormente aos concebidos pela literatura como Projeto Unesco, compreendendo-os em uma perspectiva de análise complementar aos já realizados.

4 Os estudos patrocinados pela Unesco, nessa fase, foram realizados pelos seguintes pesquisadores: Darcy Ribeiro (Brasil); Michel Leiris (Antilhas Francesas); Gabriele Wulker (Alemanha); Alfonso Caso (México); Harry J. Walker (Estados Unidos da América) e Milos Radojkovic (Iugoslávia).

5 Além dos diários de campo acerca do período que Ribeiro passou entre os Urubus-Kaapor (1949-1951), publicados na década de 1990, pude acessar outros diários de campo, bem como sua documentação pessoal e institucional, depositadas no Memorial Darcy Ribeiro.

6 Os anais da Primeira Reunião Brasileira de Antropologia foram publicados em 1957.

7 Para efeitos de uso de citações, utilizarei como base o texto publicado em 1956 na revista Sociologia.

8 Luiz Bueno Horta Barbosa ingressou no SPI em 1910. Entre 1911 e 1917, exerceu o cargo de inspetor regional e, em 1918, tornou-se diretor da instituição, permanecendo até o ano de 1921.

9 O termo "contadas" é substituído pelo termo "recenseadas" na versão em forma de capítulo do livro "Os Índios e a Civilização" de 1970, p. 288. 


\section{Referências}

ARROJADO LISBOA, M. A bacia do Gurupy e suas minas de ouro. Boletim do Departamento Nacional de Produção Mineral, n. 7, 1935.

ASSOCIAÇÃO BRASILEIRA DE ANTROPOLOGIA (ABA). Anais da II Reunião Brasileira de Antropologia. Salvador: S.A. Artes Gráficas, 1957.

AZEVEDO, M. M. A.; SIMONI, A. T. G CRUZ, A. K. R. Povos indígenas e censos na década 2010: rumo ao Censo Demográfico de 2020. In: RICARDO, B. G RICARDO, F. (Orgs.). Povos Indígenas no Brasil: 2011/2016. 1. ed. São Paulo: Instituto Socioambiental, 2017.

BRITO, C. A. G Antropologia de um jovem disciplinado: a trajetória de Darcy Ribeiro no Serviço de Proteção aos Índios (1947-1956), 2017. Tese de Doutorado, Rio de Janeiro: Casa de Oswaldo Cruz, Fundação Oswaldo Cruz.

BRITO, C. A. G. G LIMA, N. T. Antropologia e medicina: assistência à saúde no Serviço de Proteção aos Índios (1942-1956). Boletim do Museu Paraense Emílio Goeldi: Ciências Humanas, 8 (1): 95-112, 2013.

CAMPOS, M. B. G ESTANISLAU, B. R. Demografia dos povos indígenas: os censos demográficos como ponto de vista. Revista Brasileira de Estudos de População, 33(2): 441-449, 2016.

CARNEIRO DA CUNHA, M. et al. Indigenous peoples boxer in by Brazil's political crisis. HAU: Journal of Ethnographic Theory, 7(2): 403-426, 2017.

CASPAR, F. A aculturação da tribo Tupari. Revista de Antropologia, 5: 145-171, 1957.

COIMBRA JR., C. E. A. O sarampo entre sociedades indígenas brasileiras e algumas considerações sobre a prática da saúde pública entre estas populações. Cadernos de Saúde Pública, 3(1): 22-37, 1987.

DOBT, G. Descrição dos Rios Paranaíba e Gurupy. São Paulo. Cia Editora Nacional, 1939.

HEMMING, J. Die if You Must: Brazilian indians in the twentieth century. London: Macmillan, 2003.

INSTITUTO BRASILEIRA DE GEOGRAFIA E ESTATÍSTICA (IBGE). Censo Demográfico 2010: características gerais dos indígenas - resultados do universo. Rio de Janeiro, 2012.

MAIO, M. C. O projeto Unesco e a agenda das ciências sociais no Brasil dos anos 40 e 50. Revista Brasileira de Ciências Sociais, 14(41): 141-158, 1999.

MUSSOLINI, G. Os meios de defesa contra as moléstias e a morte em duas tribos brasileiras: Kaingang de Duque de Caxias e Bororó. Revista do Arquivo Municipal de São Paulo, 110: 7-152, 1946.

OLIVEIRA, R. C. Aspectos demográficos e ecológicos de uma comunidade Terena. Boletim do Museu Nacional, 18: 1-17, 1958. 
PAGLIARO, H.; AZEVEDO, M. M. G SANTOS, R. V. (Orgs.). Demografia dos Povos Indígenas no Brasil. Rio de Janeiro: Editora Fiocruz, Abep, 2005.

RIBEIRO, D. Convívio e contaminação: efeitos dissociativos da depopulação provocada por epidemias em grupos indígenas. Sociologia, 18: 3-50, 1956.

RIBEIRO, D. Os Índios e a Civilização. Rio de Janeiro: Civilização Brasileira, 1970.

RIBEIRO, D. Prefácio. In: RIBEIRO, D. Os Índios e a Civilização. 7. ed. São Paulo: Companhia das Letras, 1996a.

RIBEIRO, D. Diários Índios: os Urubu-Kaapor. 1. São Paulo: Companhia das Letras, $1996 \mathrm{~b}$.

RIBEIRO, D. Prefácio. In: GOMES, M. P. Os Índios e o Brasil: ensaio sobre um holocausto e sobre uma nova possibilidade de convivência. Petrópolis: Vozes, 1988.

RIBEIRO, D. Sobre o desaparecimento dos indígenas. Entrevista concedida a Heinz Sontag em 1969. In: CAMPOS, S.; COHN, S. G REIS, R. (Orgs.). Darcy Ribeiro: encontros. Rio de Janeiro: Beco do Azougue, 2007.

SANTOS, R. V. Prólogo ao dossiê "Demografia dos povos indígenas no Brasil: abordagens socioantropológicas". Revista Brasileira de Estudos de População, 33(2): 231-235, 2016.

SANTOS, R. V. G TEIXEIRA, P. O "indígena" que emerge do Censo Demográfico de 2010. Cadernos de Saúde Pública, 27(6): 1.048-1.049, 2011.

SERVIÇO DE PROTEÇÃO AOS ÍNDIOS (SPI). Relatório anual de atividades, Filme 335. Serviço de Gestão Documental / Museu do Índio (Sedoc/MI), 1950.

SERVIÇO DE PROTEÇÃO AOS ÍNDIOS (SPI). Relatório anual de atividades da Seção de Estudos, Serviço de Gestão Documental / Museu do Índio (Sedoc/MI), 1954.

STEWARD, J. H. The native population of South America. In: STEWARD, J. H. (Ed.). Handbook of South American Indians. v. 5. Washington: Government Printing Office, 1949.

WAGLEY, C. Os efeitos do despovoamento sobre a organização social entre os índios Tapirapé. Sociologia, 4: 407-411, 1942.

WAGLEY, C. G HARRIS, M. Minorities in the New World: six case studies. New York: Columbia University Press, 1958. 


\section{Indígenas e Pesquisa Demográfica: sugestões ao debate sobre religião e indígenas no contexto do censo brasileiro}

\section{Conhecimento, reconhecimento e desafios diante da diversidade}

Sabemos que o conhecimento sobre populações se liga diretamente ao reconhecimento de direitos às mesmas. No caso das informações censitárias sobre populações indígenas que vivem no Brasil, que vêm sendo captadas de forma sistemática desde o Censo de 1991, torna-se evidente a conexão entre este investimento de pesquisa e a mudança de orientação política que ocorre com a Constituição Federal de 1988, após um período de incremento das lutas pela conquista de direitos indígenas.

Contrastando com as políticas adotadas anteriormente para os povos indígenas no país até a década de 1970, as quais consideravam os indígenas como uma categoria social transitória, a Constituição de 1988, em seu artigo 231, afirmou os direitos especiais dos povos indígenas como povos "reconhecidos [em sua] organização social, costumes, línguas, crenças e tradições, e os direitos originários sobre as terras que tradicionalmente ocupam" (Brasil, 2000). De uma orientação que vislumbrava a "integração à comunhão nacional", passa-se ao reconhecimento de "direitos coletivos especiais" destes povos (Ricardo, 1995; Azevedo, 2008).

O valor primeiro a ser destacado na produção de informações censitárias sobre povos indígenas é, então, político. Por um lado, tornou-se obrigatória a produção de conhecimentos básicos para a implementação de políticas públicas voltadas para os indígenas a partir de 1988. Por outro lado, a introdução da pesquisa sobre indígenas no censo teve um alcance muito maior, já que, conforme observou Ricardo (1995), até a década de 1980, os povos indígenas permaneciam na invisibilidade para a grande maioria dos brasileiros. Ainda que o nível de informação da população em relação a seu contingente indígena permaneça aquém do necessário ao reconhecimento dos direitos indígenas, não se pode negar a contribuição fundamental dos três últimos censos para mudar o quadro da invisibilidade. 
Os indígenas no Brasil não ganharam apenas visibilidade a partir daí; mais que isto, os números censitários vieram a contrariar fortemente a antiga tese do desaparecimento progressivo dos povos indígenas no país. Vejam-se as taxas de crescimento bem mais altas que a média registrada para a população brasileira (Azevedo, 2000).

Um tal crescimento carrega em si mesmo uma dimensão política. Além das taxas altas de fecundidade registradas, um fator que se mostrou importante, particularmente no período de 1991 a 2000, foi o aumento dos declarados indígenas no país (IBGE, 2000b), fator que se liga certamente à definição constitucional do estatuto jurídico do indígena e à valorização social desta categoria. Pessoas que antes não se declaravam como indígenas passaram a fazê-lo, e vários grupos deram início a processos de reivindicação por reconhecimento como indígena, particularmente no Nordeste do país (Arruti, 2006; Paoliello, 2008).

Mas, desde o primeiro momento em que dão visibilidade à presença indígena no Brasil, as informações censitárias também colocam problemas à sua interpretação, bem como à elaboração de políticas públicas. O mapa dos povos indígenas apresenta grande diversidade ou "sociodiversidade nativa" (Ricardo, 1995), espécie de "mosaico de microssociedades" (Azevedo, 2000), não facilmente tratáveis como conjunto, seja analítica ou politicamente.

Como pensar em políticas públicas considerando tal multiplicidade de formas socioculturais? Como considerar as soluções históricas e as políticas indígenas adotadas por cada povo ou grupo? Notamos aqui como a produção de diferença é um mecanismo fundamental da socialidade indígena na América do Sul. Produção de diferenças em diversos níveis: no contraste com alteridades não humanas, na marcação de fronteiras étnicas, na diferenciação de posições no interior de uma mesma sociedade ou coletividade. Esta questão tem desafiado até mesmo o campo dos direitos indígenas, colocando em discussão a noção de propriedade da coletividade, como nos mostra Carneiro da Cunha (2005, 2009).

No caso da demografia, o desafio se torna lidar com um contingente que corresponde a "populações de pequeno ou médio porte, com dinâmicas demográficas distintas, revelando não só autonomias culturais como também qualidade de vida e perfis epidemiológicos muito diferentes" (Azevedo, 2008: 21).

É certo que esforços em mais de uma direção têm sido realizados para se enfrentar esse desafio, tanto por acadêmicos (Pagliaro, Azevedo G Santos, 2005; Santos G Teixeira, 2011) quanto por agentes do Estado (IBGE, 2012a). De um lado, vemos um investimento importante no aperfeiçoamento de metodologias do censo brasileiro visando a mapear as situações indígenas em suas especificidades, como o mapa das etnias e línguas faladas do Censo 2010, e também o esforço de fazer coincidir terras indígenas com setores censitários (Pereira, 2011; Azevedo, 2011). De outro lado, observamos um empenho concomitante no estudo de alternativas 
ao modelo atual do censo para a abordagem demográfica de populações indígenas. Aqui, a questão da definição de fronteiras ou unidades para comparação entre populações parece central, além do fato de que as dinâmicas indígenas não se submetem facilmente ao modelo do retrato decenal adotado pelo censo atualmente.

Sobre as fronteiras socioculturais, Ricardo já observava, em 1995, o descompasso entre aquelas definidas pelos próprios grupos indígenas e as sobrepostas pelos Estados nacionais, de modo que certas populações indígenas vivem sob a jurisdição político-administrativa de até quatro países na América do Sul.

Fica a pergunta sobre a possibilidade de metodologias alternativas capazes de mapear mais de perto os modos indígenas de habitar o tempo e o espaço. Em 1984, o estatístico Túlio Penna já sugeria a adoção de um modelo contínuo de registro de informações a ser implantado pela Fundação Nacional do Índio (Funai), junto com um departamento de estatística (Penna, 1984). Cabe lembrar também a iniciativa do Instituto Brasileiro de Geografia e Estatística (IBGE) desde 2004 para estudos da modalidade do censo contínuo, em diálogo com outros países (Silva et al., 2012).

O desafio da diversidade não se coloca apenas para o tratamento dos coletivos indígenas como conjunto. A própria categoria censitária indígena traz complexidades, como observa Azevedo (2008: 20), na medida em que inclui:

índio-descendentes que não sabem a que povo pertenciam seus ancestrais; indivíduos que moram nas cidades e que se reconhecem como pertencendo a povos/ etnias específicos; indivíduos que moram em Terras Indígenas e se reconhecem como pertencendo a povos/etnias específicos; indivíduos que se reconhecem como pertencentes a povos/etnias específicos e que estão em processo de reivindicação de suas terras, e, em alguns casos, de suas identidades étnicas.

Por sua vez, temas e conceitos definidos como instrumentos na pesquisa censitária de características populacionais estão longe de ser facilmente aplicáveis a contextos indígenas. Particularmente difícil parece ser o tratamento do tema da mobilidade indígena, das formas de ocupação e trânsito entre lugares, dos modos de concepção do "rural" e do "urbano", dos estilos de frequentação das cidades etc.

Nesse sentido, Azevedo (2011) observou como a própria definição de migração se torna discutível como componente ligado ao crescimento populacional em contextos indígenas. A autora comenta, ainda, como a presença atual de cidades indígenas dentro das terras indígenas, de bairros indígenas nas cidades ou deslocamentos de indígenas que mantêm moradia principal em sua aldeia de origem são fenômenos que complexificam a distinção usual entre rural e urbano.

Para tratar a complexidade do tema da mobilidade, Campos e Okamoto (2015), com base no estudo de dinâmicas Xakriabá, propuseram o uso do conceito de rede em substituição à pesquisa de migração (que toma como ponto de partida o corte urbano/rural). 
Estudos etnográficos podem contribuir bastante para tornar visíveis articulações entre diferentes dimensões na vida de povos indígenas. Assim, por exemplo, evidenciando conexões entre sistemas de casamento e deslocamentos em direção a cidades, como descreveu e analisou Lasmar (2005) para povos Tukano no noroeste amazônico; ou, ainda, compreendendo deslocamentos de pessoas e famílias nos termos de uma multilocalidade, como foi proposto, a partir de descrição etnográfica, para o caso dos Guarani (Mbya) que vivem no Sul e Sudeste do país (Pissolato, 2007).

Desenvolver metodologias capazes de levar em conta conexões desse tipo em substituição ao tratamento em separado de temas e posterior cruzamento de dados - parece um passo fundamental na busca de novas tecnologias na pesquisa sociodemográfica com indígenas. Teríamos aqui, quem sabe, um lugar bastante produtivo do diálogo entre antropologia e demografia.

\section{Indígenas, religião, censo}

Diversos estudiosos das religiões no Brasil têm afirmado, com relação à pesquisa sobre o tema nos censos, que o uso de religião como categoria analítica merece ser problematizado e os números dos censos, relativizados.

Steil (2013), lembrando as observações de Asad (1993) sobre a questão do poder implicado nas classificações utilizadas ao se definir certas práticas como religiosas, aponta para a possível reificação de concepções quando lidamos com dados censitários. Os cientistas sociais devem ficar vigilantes da definição de religião com que estejam operando, já que conceitos como os de história, política e religião tendem a excluir as experiências que se situam "fora do campo de visão de uma modernidade que pretende anular e encompassar as diferenças produzidas a partir das margens" (Steil, 2013: 32).

Mafra (2013), com um olhar mais direcionado às condições de produção dos dados sobre religião nos recenseamentos brasileiros, chama a atenção para a vulnerabilidade da informação sobre religião no censo, a começar pelo fato de se limitar a uma só pergunta, ainda que frequentemente a mídia se refira a "censo de religião". A autora se preocupa também com as perspectivas teórico-metodológicas na leitura dos números. Assim, sugere que outras chaves de leitura (como linhas de força e fluxos) distintas daquela do campo religioso enquanto mapa de pertenças com fronteiras bem definidas, ainda que porosas, poderiam revelar novas e interessantes possibilidades analíticas, como sinaliza para o caso de "evangélicos" e "sem religião".

Nosso interesse adiante é um exercício em dois momentos, tomando as noções de "indígena(s)" e "religião" no censo. Num primeiro momento, pretendemos acompanhar certo deslocamento da categoria indígena no contexto da pesquisa 
censitária. Isto é, quando indígena, em vez de considerado como população ou contingente, torna-se qualificativo de "religião" ou de "tradições religiosas". Num segundo momento, focalizamos a pergunta sobre religião feita a pessoas declaradas como indígenas no censo. Aqui fazemos um breve exercício de imaginação sobre a escuta da pergunta, ao mesmo tempo que buscamos relacionar os números do censo com alguns processos reconhecidos na história e etnografia de povos indígenas sul-americanos.

\section{"Tradições indígenas": variações em torno de "cultura", "religião" e "indígena"}

Conforme observado anteriormente, a década de 1990 marca um momento de valorização da categoria indígena no país, o que se liga ao aumento considerável do autorreconhecimento como indígena no contexto da pesquisa censitária. Esta valorização se revela também em outras instâncias, como a luta pelo direito à terra e a proliferação de projetos que se voltam para a preservação, o resgate ou a revitalização de culturas e tradições indígenas. É nesse período que a cultura e as tradições se tornam instrumentos políticos da maior importância na conquista de direitos e na busca de recursos de toda ordem (Carneiro da Cunha, 2009). É também quando incrementam os debates em torno da proteção de conhecimentos dos chamados povos tradicionais, e saberes indígenas são, então, discutidos enquanto patrimônios culturais destes povos (Carneiro da Cunha, 2005).

É justamente em fins dessa década, isto é, no ano 2000, que ocorre a inclusão, no questionário do censo brasileiro, da categoria "tradições indígenas" como descritora do quesito "religião", o que nos parece claramente vinculado ao processo descrito.

Mas "tradições indígenas", enquanto descritora de práticas consideradas religiosas, não se vincula, de início, à definição de "indígena" enquanto declaração de raça ou cor. A categoria parece descrever antes religiões envolvendo práticas - como o uso de substâncias psicoativas - cuja origem pode estar sendo reconhecida como indígena. Observando as subcategorias de tradições indígenas no censo, percebemos que visam a captar práticas ligadas a formas contemporâneas de religiosidade que se constroem principalmente a partir de ressignificações de elementos de tradições diversas e se localizam predominantemente nos entornos de áreas urbanas, correspondendo principalmente às religiões ayahuasqueiras (Labate, De Rose G Santos, 2008). Assim, o IBGE (2012b) inclui na categoria "tradições indígenas" as seguintes subcategorias: Santo Daime, A Barquinha, União do Vegetal, Neoxamânica, "tradições indígenas" e "outras tradições indígenas". Caberia uma reclassificação, no Censo, das configurações das chamadas religiões ayauhuasqueiras na categoria "tradições esotéricas", como sugeriu Camurça (2014). 
De todo modo, muitas dúvidas conceituais sobre o agrupamento chamado "tradições indígenas" permanecem. Elementos como a ayauhuasca estariam efetivamente na base da definição de tradições indígenas? Trata-se de reconhecer a origem indígena de certas práticas, ainda que ressignificadas em novos contextos de religiosidade? Define-se nesta categoria um saber indígena? Passando às subcategorias, nos perguntamos ainda: como se define "tradições indígenas" enquanto subcategoria de "tradições indígenas"? Haveria aqui uma certa expectativa de que as pessoas declaradas como indígenas reconhecessem suas práticas enquanto tal?

Esta última pergunta nos leva de volta ao questionamento do próprio enquadramento de práticas como religião. Como observou Menezes (2014: 66), "o censo não tem como classificar aqueles que definem suas práticas espirituais, místicas, reflexivas como sendo uma filosofia, (...) uma explicação, uma cosmologia, e não uma religião".

Sem condições de aprofundar aqui o debate das categorias, tomemos agora o contexto de aplicação da pergunta e registro de respostas acerca de religião.

\section{Procedimentos e (des)entendimentos}

Antes de imaginar as possibilidades de entendimento e as disposições de pessoas indígenas quando se deparam com a pergunta "Qual é a sua religião ou culto?", é preciso considerar quem faz a pergunta, como a faz e quem a responde, particularmente em áreas de ocupação indígena.

Faltam-nos informações sobre o treinamento de recenseadores direcionados às terras indígenas, e também sobre a aplicação dos questionários do Censo 2010 entre indígenas. Alves e colaboradores afirmam que, apesar de o questionário se definir como autodeclaração, devido a questões operacionais, na prática, muitas vezes, as informações do Censo seriam fornecidas, no caso de indígenas, por "uma parte considerável de não residentes que atuam como informantes" (Alves et al., 2017: 244).

Cecília Mariz (2013), interessada nos resultados para "evangélicos" do Censo 2010, demonstra como o conhecimento de procedimentos metodológicos é fundamental para não cairmos facilmente em armadilhas na leitura dos números. Estudando os manuais do Censo e conversando com técnicos do IBGE, a autora chama a atenção para uma possível distância entre objetivos de captação e procedimentos adotados. De um lado, "o Manual do Censo destaca a necessidade de se obter dados sobre as pertenças às diferentes igrejas", e, ainda, o Manual do Recenseador apresenta "instruções claras para não se registrarem expressões genéricas" (apud Mariz G Gracino, 2013: 164). De outro lado, os recenseadores são instruídos a não fornecer qualquer explicação ou esclarecimento adicional à pergunta sobre religião, no máximo, podem repeti-la. Mariz (2013) considera, então, que a pergunta 
não estimularia a identificação de igrejas, conforme o Censo buscava fazer. Desse modo, é possível que o crescimento da categoria genérica "evangélica", que vem desafiando a compreensão de estudiosos como tendência recente no campo das religiões no Brasil, se vincule (pelo menos parcialmente) a uma possível falta de informação na coleta.

No caso de pessoas declaradas como indígenas, os problemas se aprofundariam se considerarmos um conjunto de mediações que se interpõem entre a pergunta e a resposta, passando pelo entendimento do recenseador e do respondente. O que viria à mente de pessoas indígenas ao serem questionadas sobre ter ou não (uma) religião? Imagens ou narrativas do tempo mítico, conforme referenciado em um texto do IBGE (2005) sobre tendências demográficas com base nas amostras dos Censos 1991 e 2000? Práticas rituais? Modos de conhecimentos xamânicos como os atualizados em cantos e sonhos? Práticas curativas? Ou remeteria diretamente às religiões de origem cristã como as existentes em áreas indígenas? Como a pergunta se articularia com a dimensão política presente nas negociações atuais em torno da cultura, conforme comentado anteriormente?

Parece-nos difícil avançar na consideração dos aspectos metodológicos para além destas breves observações em torno da captação de informações em campo e no que diz respeito à categorização das religiões feitas a posteriori. Mas cabe explorar um pouco mais o tema dos números e sua interpretação, articulando-os a processos indígenas.

\section{Números e "múltiplos sentidos"}

Tomamos aqui as indicações gerais dos resultados dos últimos censos para um exercício de relativização sobre os números.

Para as duas décadas que dispomos de dados censitárias a respeito de indígenas no Brasil (entre 1991 e 2010), os números sobre religião informados para esta população acompanhariam, a princípio, as variações na adesão a religiões cristãs que vêm sendo reconhecidas para a população brasileira em geral. São elas: a diminuição do número de declarados católicos e o crescimento dos declarados evangélicos. Entre os indígenas, o número de católicos passa de 64,3\% em 1991 para aproximadamente $51 \%$ em 2010, e o percentual de evangélicos aumenta de 13,6\% em 1991 para aproximadamente 25\% em 2010. Alves e colaboradores (2017) analisam a razão entre católicos e evangélicos para pessoas que se declaram indígenas no Censo 2010, observando que o aumento dos evangélicos foi maior entre a população que se declarou indígena, comparado à razão católicos/evangélicos para o país. Quanto ao número de declarados "sem religião", este apresenta, entre os indígenas, percentual bem acima daquele informado para o conjunto da população no país - corresponde a cerca de 14,5\% entre as pessoas declaradas indígenas, 
enquanto gira em torno de 8\% para a população brasileira em geral. Por sua vez, a declaração de "tradições indígenas" no quesito "religião", incluída na versão do Censo 2000, somava 1,4\% entre os declarados indígenas, passando a 5,3\% no Censo 2010, ou seja, quase quadruplicou o número anterior.

Não nos parece possível qualquer sugestão de interpretação para os resultados de "tradições indígenas" e "sem religião" entre indígenas, já que não dispomos de elementos para avançar na discussão de problemas apontados anteriormente, nem nos é possível visualizar práticas informadas como "tradições indígenas", ou compará-las com os registros de indígenas "sem religião". De todo modo, como sugerido por Dias Junior e Verona (2014: 1.150), sem abrir mão da necessidade de estudos etnográficos, "é possível buscar respostas no próprio Censo 2010, uma vez que algumas variáveis, como língua falada, etnia e local de residência (terra indígena) podem garantir uma aproximação maior dos dados estatísticos com particularidades culturais", o que nos levaria a um melhor entendimento do fenômeno religioso entre os indígenas.

Por sua vez, quando passamos aos números referentes à declaração de indígenas como católicos ou evangélicos, questões de outra ordem nos desafiam. De um lado, sabemos da presença histórica de missões católicas e evangélicas entre povos indígenas e reconhecemos modelos de evangelização implantados em diversas regiões e etnias no país. Por exemplo, as propostas inculturativas que orientam o trabalho missionário católico sob a coordenação do Conselho Indigenista Missionário (Cimi, 2015); as iniciativas protestantes vinculadas à sistematização de línguas indígenas e tradução da Bíblia em línguas nativas promovidas pelo Summer Institute of Linguistics (SIL); a evangelização coordenada pelo Grupo de Trabalho Missionário Evangélico (GTME) e pelo Conselho de Missão entre os Índios (Comin) (Rufino, 2000). Mais recentemente, observam-se ainda outros estilos de evangelização implementados por igrejas pentecostais, bem como aqueles organizados no âmbito da Associação de Missões Transculturais Brasileiras (AMTB), que reúne inúmeras denominações evangélicas e investe no trabalho que denomina "treinamento indígena" direcionado à formação de "pastores indígenas evangélicos" (AMTB, 2015).

Entretanto, se todas essas presenças, mais ou menos longevas, fazem parte da história de muitas pessoas e coletivos indígenas que vivem no Brasil, ainda assim nos cabe perguntar sobre o alcance e os sentidos das declarações de indígenas como católicos ou evangélicos. Pensamos nos debates desenvolvidos na etnologia sobre os sentidos da conversão, a transformação indígena de conceitos, a dimensão da "abertura ao Outro" (Lévi-Strauss, 1993), que marcam as políticas indígenas, além dos usos da religião em contextos contemporâneos de negociação para a garantia de direitos.

Gostaríamos de destacar aqui esse aspecto da apropriação dos indígenas de capacidades e conhecimentos de outros povos ou culturas com que se põem 
em relação: o que aos olhos das organizações missionárias pode ser traduzido em números de evangelização, na experiência de pessoas e povos indígenas pode ganhar sentidos bastante diversos. Vale lembrar da Santidade de Jaguaripe na Bahia do século XVI, reunindo práticas religiosas de diferentes origens (Vainfas G Souza, 2000); do processo de conversão e desconversão vivido pelos Wari' (Rondônia) nos anos 1970 e 1980 (Vilaça, 1996); dos mais diversos sentidos que a adoção de identidades, como as de "cristão" ou "crente", pode assumir na prática (Wright, 1999).

A complexidade desses processos mereceu investimentos teóricos importantes na antropologia, com a elaboração de conceitos, como os de "indigenização" (de crenças e práticas ocidentais), "mediação" (Montero, 2006) ou "tradução" (Pompa, 2003), para dar conta dessas experiências.

Mas, como observado anteriormente, o contexto atual de negociações para a conquista de direitos à terra e a outros recursos coloca novos problemas. Para além de se orientarem por seus regimes de conhecimento, os indígenas precisam atualmente dar visibilidade a certas práticas e conhecimentos tidos como tradicionais. Estas tradições - entre elas, as tradições religiosas, - agora fundamentam direitos, de modo que, como apontou Carneiro da Cunha (2009), torna-se necessário operar com duas formas de discursividade, viver simultaneamente sob a égide da cultura e da "cultura" (com aspas, ou seja, em sua expressão objetivada que deve ser demonstrada). Aqui poderíamos nos perguntar: quais os usos da religião que poderiam estar em jogo no contexto atual, que põe, então, em relação uma tradição marcada pela abertura ao exterior - voltada para a captura de capacidades controladas por alteridades humanas e não humanas - com uma tradição que deve se afirmar indígena com base justamente na distinção em relação a outras tradições? E, voltando ao Censo, como estes usos possivelmente se atualizam nas respostas à pergunta sobre religião?

\section{Considerações para adiante}

O propósito deste capítulo foi buscar algumas possíveis articulações entre indígenas e religião, no contexto da pesquisa demográfica que vem sendo realizada pelos últimos censos brasileiros.

Seguindo a trilha de categorias censitárias e nos aproximando de processos descritos na história e etnografia de povos indígenas sul-americanos, deparamo-nos com complexidades que desafiam a construção de metodologias para a pesquisa demográfica e a abordagem e análise de resultados dos censos. É o caso do encontro da ideia de "tradições indígenas", que incorpora pressupostos do conceito ocidental de religião, com o termo "indígena" como definidor de uma parcela da população brasileira. 
As questões aqui levantadas pretendem contribuir para o diálogo entre diferentes disciplinas, particularmente antropologia e demografia, não só para uma leitura mais rica das informações censitárias de que dispomos atualmente, mas, principalmente, para a construção de instrumentos de coleta e análise cada vez mais articulados com a vida de pessoas e grupos indígenas no Brasil e a multiplicidade de experiências que ela abarca.

\section{Referências}

ALVES, J. E. D. et al. Cambios en el perfil religioso de la población indígena del Brasil entre 1991 y 2010. Notas de Población, 104: 237-262, 2017.

ARRUTI, J. M. Etnogêneses indígenas. In: RICARDO, B.G RICARDO, F. (Orgs.). Povos Indígenas no Brasil 2001-2005. São Paulo: Instituto Socioambiental, 2006. Disponível em: <www.socioambiental.org >. Acesso em: 25 nov. 2015.

ASAD, T. Genealogies of Religion: disciplines and reasons of power in Islam and Christianity. Baltimore: John Hopkins University Press, 1993.

ASSOCIAÇÃO DE MISSÕES TRANSCULTURAIS BRASILEIRAS (AMTB). Site. Disponível em:<www.amtb.org.br>. Acesso em: 25 nov. 2015.

AZEVEDO, M. Quantos eram? Quantos serão? In: RICARDO, B.G RICARDO, F. (Orgs.). Povos Indígenas no Brasil 1996-2000. São Paulo: Instituto Socioambiental, 2000. Disponível em:<www.socioambiental.org>. Acesso em: 25 nov. 2015.

AZEVEDO, M. Diagnóstico da população indígena no Brasil. Ciência e Cultura (SBPC), 60: 19-22, 2008.

AZEVEDO, M. O Censo 2010 e os povos indígenas. In: RICARDO, B.G RICARDO, F. (Orgs.). Povos Indígenas no Brasil 2006-2010. São Paulo: Instituto Socioambiental, 2011. Disponível em:<www.socioambiental.org>. Acesso em: 25 nov. 2015.

BRASIL. Presidência da República. Constituição da República Federativa do Brasil. Org. Alexandre de Moraes. 16. ed. São Paulo: Atlas, 2000.

CAMPOS, M. G OKAMOTO, L. A migração dos indígenas a partir dos dados do Censo Demográfico 2010. In: SEMINÁRIO DE DEMOGRAFIA DOS POVOS INDÍGENAS: SAÚDE, TERRITÓRIO E AMBIENTE, VIII, 2015, Rio de Janeiro.

CARNEIRO DA CUNHA, M. Introdução: patrimônio imaterial e biodiversidade. Revista do Patrimônio Histórico e Artístico Nacional, 32: 15-27, 2005.

CARNEIRO DA CUNHA, M. "Cultura" e cultura: conhecimentos tradicionais e direitos intelectuais. In: CARNEIRO DA CUNHA, M. Cultura com Aspas e Outros Ensaios. São Paulo: Cosac e Naify, 2009. 
CAMURÇA, M. A. A religião e o censo: enfoques metodológicos - uma reflexão a partir das consultorias do Iser ao IBGE sobre o dado religioso no Censo. In: CUNHA, C. G MENEZES, R. (Orgs.). Religiões em conexão: números, direitos, pessoas. Comunicações do Iser, 69, set. 2014.

CONSELHO INDIGENISTA MISSIONÁRIO (CIMI). Site. Disponível em: <www.cimi.org.br> . Acesso em: 25 nov. 2015.

DIAS JR., C. S G VERONA, A. P. Perfil religioso da população autodeclarada indígena no Brasil: considerações a partir do Censo Demográfico de 2010. Horizonte, 12(36): 1.1401.159, 2014.

INSTITUTO BRASILEIRO DE GEOGRAFIA E ESTATÍSTICA (IBGE). Tabulação Avançada do Censo Demográfico 2000: resultados preliminares da amostra. Rio de Janeiro: IBGE, 2000a. (140 Anexos)

INSTITUTO BRASILEIRO DE GEOGRAFIA E ESTATÍSTICA (IBGE). Características Gerais da População, Resultados da Amostra. Rio de Janeiro: IBGE, 2000b.

INSTITUTO BRASILEIRO DE GEOGRAFIA E ESTATÍSTICA (IBGE). Tendências Demográficas: uma análise dos indígenas com base nos resultados da amostra dos censos demográficos 1991 e 2000. Rio de Janeiro: IBGE, 2005.

INSTITUTO BRASILEIRO DE GEOGRAFIA E ESTATÍSTICA (IBGE). Censo Demográfico 2010: características gerais dos indígenas - resultados do universo. Rio de Janeiro: IBGE, 2012a.

INSTITUTO BRASILEIRO DE GEOGRAFIA E ESTATÍSTICA (IBGE). Censo Demográfico 2010: características gerais da população, religião e pessoas com deficiência. Rio de Janeiro: IBGE, $2012 b$.

LABATE, B. C.; DE ROSE, I. C. G SANTOS, R. G. Religióes Ayahuasqueiras: um balanço bibliográfico. Campinas: Mercado das Letras, 2008.

LASMAR, C. De Volta ao Lago de Leite: gênero e transformação no Alto Rio Negro. São Paulo: Editora Unesp, 2005.

LÉVI-STRAUSS, C. História de Lince. São Paulo: Companhia das Letras, 1993.

MAFRA, C. Números e narrativas. Debates do NER, 14(24): 13-25,2013.

MARIZ, C. O que precisamos saber sobre o censo para falar sobre seus resultados? Um desafio para novos projetos de pesquisa. Debates do NER, 14(24):39-58, 2013.

MARIZ, C. G GRACINO, P. As igrejas pentecostais no Censo de 2010. In: TEIXEIRA, F. G MENEZES, R. (Orgs.). Religiões em Movimento. Petrópolis: Vozes, 2013.

MENEZES, R. Religiões, números e disputas sociais. Comunicações do Iser (69): 60-71, 2014.

MONTERO, P. Índios e missionários no Brasil: para uma teoria da mediação cultural. In: MONTEIRO, P. (Org.). Deus na Aldeia: missionários, índios e mediação cultural. São Paulo: Globo, 2006. 
PAOLIELLO, T. O crescimento da presença indígena nos censos nacionais 1991-2000: uma análise da região Nordeste. In: ENCONTRO NACIONAL DE ESTUDOS POPULACIONAIS, XVI, 2008, Caxambu.

PAGliARO, H.; AZEVEDO, M. G SANTOS, R. V. (Orgs.). Demografia dos Povos Indígenas no Brasil. Rio de Janeiro: Editora Fiocruz, Abep, 2005.

PENNA, T. C. F. Por que demografia indígena brasileira? In: ENCONTRO NACIONAL DE ESTUDOS POPULACIONAIS, IV, 1984, Águas de São Pedro. Anais... São Paulo: Abep, 1984. v. 3.

PEREIRA, N. O. M. Os Indígenas nas Informações Censitárias: potencialidades e limitações com base em um estudo de caso sobre os Xavante, Mato Grosso, 2011. Tese de Doutorado, Rio de Janeiro: Escola Nacional de Saúde Pública Sérgio Arouca, Fundação Oswaldo Cruz.

POMPA, C. Religião como Tradução: missionários, Tupi e Tapuia no Brasil colonial. Bauru: Edusc, 2003.

PISSOLATO, E. A duração da pessoa: mobilidade, parentesco e xamanismo mbya (guarani). São Paulo: Editora Unesp, 2007.

PISSOLATO, E. "Tradições indígenas" nos censos brasileiros: questões em torno do reconhecimento indígena e da relação entre indígenas e religião. In: TEIXEIRA, F. G MENEZES, R. (Orgs.). Religiões em Movimento. Petrópolis: Vozes, 2013.

RICARDO, C. A. Os índios e a sociodiversidade nativa contemporânea no Brasil. In: SILVA, A. G GRUPIONI, L. (Orgs.). A Temática Indígena na Escola: novos subsídios para professores de $1^{\circ}$ e $2^{\circ}$ graus. Brasília: MEC, Unesco, Mari, 1995.

RUFINO, M. Nem só de pregação vive a missão. Instituto Socioambiental, 2000. Disponível em: <www.pib.socioambiental.org.br>. Acesso em: 20 nov. 2015.

SANTOS, R. V. G TEIXEIRA, P. O "indígena" que emerge do Censo Demográfico de 2010. Cadernos de Saúde Pública, 27(6): 1.048-1.049, 2011.

SILVA, A. D. et al. Estudo da modalidade de censo demográfico contínuo. In: ENCONTRO NACIONAL DE ESTUDOS POPULACIONAIS, XVIII, 2012, Águas de Lindóia.

STEIL, C. A. Mapas e hologramas como metáforas para pensar os dados sobre religião no censo do IBGE de 2010: comentários ao texto "Números e narrativas" de Clara Mafra. Debates do NER,14(24): 29-37, 2013.

VAINFAS, R. G SOUZA, J. B. Brasil de Todos os Santos. Rio de Janeiro: Zahar, 2000.

VILAÇA, A. Cristãos sem fé: alguns aspectos da conversão dos Wari' (Pakaa Nova). Mana: Revista de Antropologia Social, 2(1): 109-137, 1996.

WRIGHT, R. (Org.). Transformando os Deuses: os múltiplos sentidos da conversão entre os povos indígenas no Brasil. Campinas: Unicamp, 1999. 


\section{Os Indígenas nos Censos Demográficos: entrevista com João Pacheco de Oliveira}

João Pacheco de Oliveira Marta Antunes

\section{Apresentação}

João Pacheco de Oliveira é antropólogo e professor titular no Museu Nacional da Universidade Federal do Rio de Janeiro. Fez pesquisa de campo prolongada com os índios Tikuna, do Alto Solimões (Amazônia). Conduziu também diversas investigações sobre políticas públicas, coordenando um amplo projeto de monitoramento das terras indígenas no Brasil (1986-1994). Foi presidente da Associação Brasileira de Antropologia (ABA) (1994-1996) e, por diversas, vezes atuou como coordenador da Comissão de Assuntos Indígenas. Nos últimos anos, vem se dedicando ao estudo de questões ligadas à antropologia do colonialismo e à antropologia histórica, desenvolvendo trabalhos relacionados ao processo de formação nacional, à historiografia, bem como a museus e coleções etnográficas. Junto com lideranças indígenas, foi um dos fundadores do Maguta: Centro de Documentação e Pesquisa do Alto Solimões, sediado em Benjamin Constant (AM), que deu origem ao Museu Maguta, administrado hoje diretamente pelo movimento indígena. Esta entrevista foi realizada pela antropóloga Marta Antunes (IBGE), no âmbito da reunião organizada pelo Grupo de Trabalho Povos e Comunidades Tradicionais do Instituto Brasileiro de Geografia e Estatística (IBGE), realizada em maio de 2017, com atores-chave na temática indígena, iniciando o processo de reflexão acerca dos censos com o objetivo de construir insumos para aperfeiçoamento metodológico e operacional do Censo Demográfico de 2020.

Em sua trajetória acadêmica, você tem publicado algumas reflexões sobre os dados dos censos demográficos e a forma como a população indígena residente no Brasil é (e não é) retratada pelos mesmos, em particular, os artigos "Entrando e saindo da mistura" e "Trama histórica e mobilizações indígenas atuais" (Oliveira, 1999, 2000, 2011). É raro observarmos trabalhos acadêmicos de antropologia, como os mencionados de sua autoria, que utilizam estatísticas oficiais e refletem sobre as mesmas. O que o levou a se debruçar sobre esses dados? 
Tenho participado, nos últimos dez anos, nas discussões com o IBGE, tendo sido indicado, em 2016, pelo então presidente da ABA, Antônio Carlos de Souza Lima, para representar a associação na discussão sobre o Censo Demográfico de 2020. Identifico um desinteresse da maior parte dos colegas antropólogos em relação aos dados estatísticos, provavelmente porque, para eles, esses dados implicam uma leitura muito árida. Os antropólogos desconfiam dos resultados e geralmente só querem discutir o processo de coleta e confrontar os dados nacionais gerais com a experiência localizada que eles têm dentro de um povo ou de uma comunidade. Por esse motivo, o diálogo muitas vezes não é simples. Eu tenho uma outra experiência, trabalhei sempre com dados quantitativos. Meu primeiro trabalho de campo foi um mapeamento de um grupo extenso do Alto Solimões. Essa foi uma experiência preliminar antes do trabalho intenso dentro de uma aldeia com entrevistas e outras atividades relacionadas. Por isso, considero os dados quantitativos muito importantes para mim e para a sociedade brasileira.

Ao analisar os dados dos censos de 1872 e 1890 (Oliveira, 1999, 2000), você chama a atenção para o jogo classificatório que leva ao crescimento da categoria "cabocla", como se, ao se classificar como "cabocla", a pessoa conseguisse se afastar do estigma da escravidão, tão presente nas categorias "preto" e "pardo". Você enfatiza ainda que, nos censos nacionais posteriores ao de 1890, o "caboclo" deixou de corresponder a uma das alternativas classificatórias e ficou incluído na categoria "pardo", que passou a ser aplicada a toda e qualquer forma de mestiçagem. Consequentemente, entre 1890 e 1940, os censos não fornecem dados específicos sobre os indígenas que habitavam o território nacional. Como você avalia a evolução dos censos demográficos desde a introdução da categoria "indígena" no quesito "cor ou raça" em 1991, inicialmente no questionário da amostra, e, em 2010, no questionário básico?

O Censo Demográfico de 1991 já apresentou muitas novidades, mas, ao analisarmos o de 2000, só podemos classificá-lo como espetacular em relação às interpretações que propicia do Brasil. Este censo mostra índios em praticamente dois terços dos municípios brasileiros, destrói uma série de mitos em relação à concentração indígena em apenas determinadas áreas. Foi um marco fundamental e que ainda pode ser mais explorado pela antropologia. Com isso, não estou afirmando que não fosse necessário aperfeiçoá-lo. O Censo de 2010, por sua vez, aprofundou, sobretudo, com a colaboração da Fundação Nacional do Índio (Funai), os aspectos relativos às terras indígenas (TIs). É um censo que permite pela primeira vez individuar povos e línguas, o que considero extraordinário, um enorme avanço.

Em contrapartida, o Censo 2010 deixou alguns aspectos a descoberto. Minha principal crítica diz respeito às populações indígenas residentes em cida- 
des. Tenho participado de muitos encontros com etnólogos, em universidades de diferentes áreas do país, e sempre sinto uma insatisfação muito grande em relação aos dados apresentados sobre os índios residentes nos centros urbanos. Quando comparamos os resultados dos Censos Demográficos de 2010 e 2000, estranhamos a diminuição de indígenas nas cidades, porque não há qualquer possibilidade de se pensar que eles tenham se reduzido. De fato, vem aumentando a quantidade de indígenas que vão estudar e/ou trabalhar nas cidades, que são atraídos pela vida nos centros urbanos. Essa avaliação, compartilhada por organizações indígenas, entidades indigenistas e estudiosos da área, não coincide com os dados do Censo de 2010. Acho que houve um problema que deveria ser corrigido no próximo censo.

Qual é a sua avaliação do conceito de "aldeia indígena" ("agrupamento de, no mínimo, 20 indígenas em uma ou mais moradias"), utilizado pelo IBGE, para planejar sua operação censitária, à luz da forma como essa categoria é utilizada pela antropologia e pelos próprios indígenas. Que sugestões você apresentaria ao IBGE, considerando que o Grupo de Trabalho (GT) Povos e Comunidades Tradicionais dessa instituição está em processo de revisão do conceito? O conceito de aldeia utilizado com diferentes significados pelas várias instituições que produzem dados sobre os indígenas poderia explicar as diferenças entre os dados do IBGE e os dados da Funai, da Secretaria Especial de Saúde Indígena (Sesai) e do Instituto Socioambiental (ISA)?

Embora a noção de aldeia atualmente se aproxime do senso comum, no período colonial, de fundação do Brasil, ela tinha uma definição muito precisa. A aldeia era uma unidade missionária estabelecida sob controle de um agente externo que reunia diferentes populações, diferentes línguas, com o intuito de catequização. Não eram considerados aldeias os espaços administrados por particulares. No correr dos usos, esse conceito mudou muito. Hoje tem um aspecto muito importante: é utilizado pela Funai porque corresponde a uma categoria adotada pelos próprios indígenas para marcar sua condição indígena: "Isto aqui é uma aldeia! Isso aqui não é qualquer coisa, nós somos índios". Ou seja, essa categoria tem um significado étnico muito importante que precisa ser contemplado.

As diferenças entre os dados da Funai, da Sesai, do ISA e os do próprio IBGE precisam ser discutidas aprofundadamente, o que está acontecendo em reuniões com especialistas promovidas pelo IBGE. Talvez seja necessário avançar nas reflexões para além das conceituações, com foco na forma de operacionalização da enquete, o que pode explicar números contrastantes entre as instituições. 
No seu artigo "Trama histórica e mobilizações indígenas", você afirma que "medir é uma forma de arbitrar sobre direitos" (Oliveira, 2011: 654). Como você relaciona a conceituação de "aldeia" com essa dimensão política da estatística?

Um censo é uma política de Estado. É uma ação de Estado. Ele pode, por um lado, gerar dados propiciando uma melhor assistência a determinadas populações. Nesses casos, o censo é um instrumento de políticas públicas. Quando se trabalha com a ideia de aldeia no âmbito da saúde, da educação, ou no caso da Funai mesmo, a forma como essa categoria é definida pelas diferentes instituições está relacionada com a intenção de assistência desses órgãos, que têm como fim a implementação de políticas e programas públicos específicos. Por outro lado, a estatística pode estar ligada a uma intenção mais abrangente, que é a intenção do IBGE de realmente fazer um retrato do Brasil, uma compreensão do país mais geral. Às vezes, essa finalidade é meio descurada, mas é muito importante porque o IBGE tem como obrigação ou como desafio fazer um retrato da população brasileira que não oculte a sua diversidade, diferentemente da Funai, da Sesai, do ISA e de outros atores que estão trabalhando com objetivos específicos. Portanto, aperfeiçoar essa dimensão de conhecimento, ou seja, a capacidade de captar a diversidade é um investimento de energia, de esforços, que vale a pena ser feito.

Considerando as propostas apresentadas pelo GT Povos e Comunidades Tradicionais do IBGE, na reunião de maio de 2017, com o objetivo de garantir esse retrato que visibilize a diversidade do que é denominado "aldeia indígena", aposto na flexibilização do conceito de aldeia como um caminho a ser seguido. Uma questão a ser discutida é a que se refere ao quantitativo mínimo de indígenas que hoje é de vinte. Acho que, quanto menor o número, melhor. Às vezes um grupo de 15 pessoas pode ser um grupo de referência fundamental dentro de uma população indígena de mil e quinhentos, mas entendo que há limites decorrentes dos impactos numa operação censitária, e que o IBGE deva fixá-los, levando em conta esse equilíbrio entre representação e viabilidade.

Alguns conceitos de aldeia utilizados atualmente, inclusive o da Funai, pressupõem uma alteração do espaço com construções coletivas dos indígenas ou realizadas por instituições públicas. Acredita que essa dimensão deve constar de uma conceituação de aldeia do IBGE?

Sou pouco simpático à ideia de falar de construções ou de coisas públicas como dimensão necessária para que a categoria "aldeia" seja aplicada pelo IBGE a um grupo local de indígenas. Sabemos que há uma tendência das instituições estatais de produzirem sedentarização de populações que não estão ainda sedentarizadas e que não desejam esse processo. É preciso compreender que nem sempre 
os indígenas valorizam o mesmo que nós. Eles não desejam ter uma terra fixada para ser permanentemente explorada. Eles preferem circular, ou seja, abandonar sua terra por um tempo e ir para uma área nova que tenha melhores condições de cultivo, de caça, entre outras. Às vezes se deslocam por razões religiosas. Embora usemos a imagem dos cemitérios para ajudar a definir terra indígena, a relação com os mortos nem sempre é fácil para as comunidades indígenas. Pode ser muito desagradável permanecer em uma área fechada estabelecendo relações com tantas gerações de parentes mortos. São várias as questões que impulsionam a circulação e mobilidade dentro das terras indígenas e entre aldeias, incluindo a criação e dissolução de aldeias. Em suma, há uma tendência dos indígenas a migrar e, se eles estão dentro de uma terra indígena ou de uma área reconhecida, eles têm todo o direito de se deslocarem, e não ficar permanentemente ali. A educação e a saúde têm que se adaptar ao modo de vida deles e não podem produzir uma sedentarização negativa.

Como você vê a questão dos agrupamentos de indígenas, em áreas urbanas e no entorno delas, que vêm crescendo nos mapeamentos realizados pelo IBGE desde o Censo de 2010?

Não acho que deveríamos valorizar demais essa dimensão do urbano. Em relação aos indígenas, é preciso tomar bastante cuidado com a ideia de que a urbanização é um processo inexorável que leva do atraso ao progresso. Além desse fato, é necessário ter em mente que vivemos em um contexto no Brasil no qual há que se ter muito cuidado com a utilização de dados. Os antropólogos estão tomando essa precaução em relação aos seus laudos e relatórios, assim como a toda a sua produção, porque esses dados estão sendo utilizados negativamente pela mídia e até mesmo por advogados.

Tenho uma preocupação muito grande com a questão da aldeia. Apesar de ser uma noção interessante e positiva, é necessário estarmos atentos ao mau uso que possa ser feito da mesma. Seria importante que o IBGE produzisse uma nota técnica em relação a essa categoria, explicando que o Censo produziu um retrato temporalmente localizado, que naquele momento os indígenas estavam ali, mas que, em outro momento, podem estar em outras partes do território. As aldeias não são estanques e fixas espacialmente, e os indígenas necessitam para a sua vida dessas outras partes do território.

Em nossas análises, também deveríamos tomar cuidado em relação a esses dados, para que não se dissociem muito da questão das terras. Devemos enfatizar que os índios se mobilizam, lutam, criam identidades e que as terras e as aldeias são unidades que os antropólogos chamam de grupos locais, onde as pessoas se reúnem em uma interação mais cotidiana, mas não são sequer unidades suficientes 
do ponto de vista de casamento, de relações econômicas ou de relações rituais. Não é como se estivéssemos falando de Rio de Janeiro ou São Paulo, onde as pessoas vivem circuitos diferentes. Acho importante fazer essa distinção. É importante reavaliar se a categoria "aldeia" é a mais adequada. No meio rural brasileiro, a expressão "comunidade" é muito utilizada entre os indígenas que falam melhor o português. Talvez essa expressão possa ser uma alternativa. Além disso, a ideia de comunidade tem uma certa vantagem porque coloca o foco sobre a interação entre as pessoas. Associo essa noção ao conceito de "comunização" de Weber, a ideia de que a sociedade e as suas unidades existem porque as pessoas estão interagindo umas com as outras. Se elas não interagissem, mesmo que estivessem lado a lado, não formariam uma sociedade ou uma comunidade. Então, é a vontade das pessoas em interagir, criar instituições que possibilitem a convivência delas, que é valorizada.

Considerando toda essa discussão, enfatizo que a ideia de urbano é bastante complexa em relação aos indígenas, porque eles não trilham caminhos definitivos. Assim como os migrantes em geral, que muitas vezes têm o deslocamento como estratégia temporária, os indígenas têm frequentemente, além dessa transitoriedade da migração, apostas muito claramente estabelecidas dentro das suas próprias comunidades, têm papéis rituais, políticos e econômicos, e consideram seriamente a possibilidade de voltar. Além disso, grande parte das áreas está em processo de definição, e até mesmo algumas das que estão definidas apresentam problemas, porque estão sendo invadidas ou por qualquer outra razão.

Em suma, há diversos fatores que favorecem o deslocamento dos indígenas. Contudo, na medida em que os problemas são resolvidos, eles tentam retornar às comunidades de origem. Às vezes ficam por um tempo na cidade para estudar, vão e voltam, como se fosse um circuito. É importante salientar nesta discussão que não há elementos para afirmar que os indígenas que residiam em cidades no momento da coleta do Censo, tinham necessariamente um projeto de vida urbano. Em alguns casos, querem estudar ou acumular recursos, mas isso não significa que estão desvinculados das suas comunidades.

Os antropólogos e a Funai tiveram muito mais contato com os índios territorializados, os índios que estão dentro de áreas específicas, por várias razões que não cabe discutir aqui. Entretanto, os índios que estão vivendo em centros urbanos são muito importantes, devem ser estudados e representados.

Você tem participado de algumas discussões com o IBGE sobre o quesito de "cor ou raça". Nessa pergunta feita aos informantes, a categoria "indígena" é apresentada como última opção, depois de "branco", "preto", "amarelo" e "pardo". Em 2010, o IBGE inovou construindo uma pergunta de cobertura que só foi aplicada em TIs - "Você se considera indígena?" -, pergunta essa que captou cerca de 15\% 
do total da população indígena dentro das TIs. Em sua avaliação, de que maneira o IBGE vem possibilitando a representação estatística dos indígenas no Brasil?

Pensando nas implicações políticas do uso dos dados sobre índios no Brasil, acho que deveríamos compará-los com os de outros países. Por exemplo, a população indígena na Argentina, segundo dados do Banco Mundial, é quase a mesma que a do Brasil em termos absolutos. No entanto, a Argentina tem uma população total de residentes muito menor do que a nossa, o que significa que, naquele país, quase 5\% da população é indígena e, no Brasil, o percentual é em torno de 0,5\%.

O número de índios no Brasil é muito pequeno porque as nossas estruturas reprimem a possibilidade de ser indígena, inclusive o censo demográfico. O censo deveria ser mais amigável em relação às declarações de condição indígena. A pergunta "qual é sua cor ou raça" apresenta problemas, porque nem todos os indígenas têm uma única cor, como aliás qualquer ser humano. No caso deles, a ideia de raça é totalmente inadequada, porque os indígenas vão definir a sua raça como Xavante, por exemplo, ou vão falar "não sei". Não vão associar raça à condição indígena.

Nesse sentido, uma pergunta do tipo "você se considera indígena", uma pergunta direta, elaborada pensando na forma como o indígena se percebe, permite que a opção de resposta "indígena" não esteja misturada com outras categorias de resposta que não dialogam com ela. Para muitos indígenas, principalmente em contexto urbano, o elenco de categorias que começa com branco, preto, amarelo, pardo, pode confundi-los. A aplicação dessa pergunta ("se considera indígena"), aliada a uma abordagem mais específica para a operação do censo demográfico nas comunidades indígenas, contribuiria para o desafio do IBGE de fazer um retrato da população brasileira que não oculte a sua diversidade. Seria conveniente que essa pergunta adicional fosse feita nos lugares em que se identificou a presença de pessoas que já se declararam indígenas no último censo. O ideal seria até estender ainda mais a área de aplicação da pergunta, mas, provavelmente, os argumentos econômicos iriam pesar nessa decisão. Então, aposto na flexibilização do conceito de aldeia como um caminho interessante para ampliar a aplicação dessa pergunta mais direta de pertencimento étnico a um grupo maior de setores censitários, quando comparado com o Censo Demográfico de 2010.

Você considera possível que essa estrutura metodológica e operacional de pesquisa censitária que vem sendo aprimorada a cada censo com enfoque na população indígena possa ser adaptada para outros povos e comunidades tradicionais, como é o caso das comunidades quilombolas?

Uma parte significativa desse saber de Estado criado para quantificar os indígenas pode ser aplicada para populações não indígenas com bons resultados. 
As diversas populações tradicionais têm muitas características em comum com os povos indígenas. Desse modo, é possível derivar adaptações dessa metodologia que está em discussão para as comunidades quilombolas, por exemplo, estimulando um diálogo com outras formas de pensar estatísticas censitárias para essas populações. Analisando o censo hoje, o retrato do Brasil ainda está focado no branco, e pensado a partir do Oceano Atlântico e das cidades. Provocar mudanças nessa representação do país pode gerar resultados muito interessantes, e considero o censo demográfico como o espaço apropriado para essa aposta, porque ele produz estatísticas oficiais, e estas são, ao mesmo tempo, política de Estado e reflexo das políticas de Estado. Para concluir, quero ressaltar que, se houver da parte do IBGE interesse e possibilidade de fazer mudanças na forma de retratar o Brasil na sua diversidade, com pesquisas qualitativas adicionais, estaremos perante mais um aperfeiçoamento deste trabalho censitário, no patamar do que observamos entre 2000 e 2010.

\section{Referências}

OLIVEIRA, J. P. Entrando e saindo da mistura. In: OLIVEIRA, J. P. Ensaios em Antropologia Histórica. Rio de Janeiro: Editora UFRJ, 1999.

OLIVEIRA, J. P. Entering and leaving the "melting pot": a history of Brazilian indians in the national censuses. Journal of Latin American Anthropology, 4(2)-5(1): 190-211, 2000.

OLIVEIRA, J. P. Trama histórica e mobilizações indígenas atuais: uma antropologia dos registros numéricos no Nordeste. In: OLIVEIRA, J. P. (Org.). A Presença Indígena no Nordeste: processos de territorialização, modos de reconhecimento e regimes de memória. Rio de Janeiro: Contra Capa, 2011. 


\section{Memórias Acadêmico-Afetivas sobre a Demografia dos Povos Indígenas no Brasil: entrevista com Marta Maria do Amaral Azevedo}

Marta Maria do Amaral Azevedo Alessandra Traldi Simoni Bruno Nogueira Guimarães

Ricardo Ventura Santos

\section{Apresentação}

Sobretudo a partir dos anos 1980, a antropóloga e demógrafa Marta Maria do Amaral Azevedo acompanhou e participou de diversas iniciativas de recenseamentos autônomos e contagens das populações indígenas, conduzidas pela sociedade civil e pelo Estado. Pesquisadora do Núcleo de Estudos de População Elza Berquó (Nepo) e professora do Programa de Pós-Graduação em Demografia da Universidade Estadual de Campinas (Unicamp), Marta Azevedo é uma das autoras que, nas últimas décadas, mais expressivamente contribuiu para estabelecer e expandir as pesquisas em demografia indígena no Brasil. Atuou em importantes organizações de apoio aos povos indígenas, como o Centro Ecumênico de Documentação e Informação (Cedi), o Instituto Socioambiental (ISA), a Comissão Pró-Índio de São Paulo (CPI/SP) e o Conselho Indigenista Missionário (Cimi). Foi presidente da Fundação Nacional do Índio (Funai) e uma das fundadoras do Grupo de Trabalho de Demografia dos Povos Indígenas no Brasil da Associação Brasileira de Estudos de População (Abep) e da Associação Latino-Americana de População (Alap). Atualmente é integrante do Conselho Consultivo do Censo Demográfico Nacional 2020.

A base desta entrevista foi a conferência "Memórias afetivo-acadêmicas da demografia dos povos indígenas", proferida no IX Seminário do Grupo de Trabalho Demografia dos Povos Indígenas da Abep, realizado no Centro de Desenvolvimento e Planejamento Regional (Cedeplar) da Universidade Federal de Minas Gerais (UFMG), em outubro de 2017. Em 2018, como parte das atividades de um projeto de pesquisa acerca da trajetória da constituição do campo da demografia dos povos indígenas no Brasil, Marta Azevedo concedeu uma série de entrevistas, na cidade de São Paulo e em Campinas, a Ricardo Ventura Santos, Bruno Guimarães e Alessandra Traldi Simoni, ${ }^{1}$ cujos conteúdos foram, em parte, incorporados ao texto resultante da transcrição da conferência. 
O interesse pela demografia foi sendo constituído ao longo da minha atuação como antropóloga com os povos indígenas. Em 1974, quando ingressei no curso de ciências sociais na Universidade de São Paulo (USP), já tinha interesse em trabalhar com povos indígenas. ${ }^{2}$ Lembro muito bem da aula inaugural daquele ano, ministrada por José de Souza Martins. Ele perguntou aos alunos no auditório, que estava cheio, quem queria seguir nas áreas de ciência política, sociologia ou antropologia. Somente eu e mais algumas poucas pessoas, no máximo dez, estávamos interessados em antropologia. Recordo-me que Martins disse que era melhor mudarmos de ideia porque em pouco tempo poderia não haver mais indígenas no Brasil. Isso é curioso, pois mostra que, no começo dos anos 1970, havia um certo consenso na comunidade científica de que a população indígena estava em decréscimo e, nesse cenário, deixaria de existir enquanto etnicamente distinta da população nacional. Felizmente essa noção foi desconstruída ao longo das décadas seguintes, pela ação de uma rede de pesquisadores de diversas áreas - antropologia, linguística, geografia, entre outras -, missionários, indigenistas e indígenas.

Durante a graduação tive pouco contato com antropólogos ou etnólogos, com exceção das professoras Sylvia Caiuby, Aracy Lopes da Silva e Lux Vidal. No terceiro ou quarto ano, pude cursar duas matérias eletivas: uma sobre mito e rito no pensamento antropológico, com a professora Aracy; e a outra sobre antropologia brasileira, com a professora Lux. Já graduada, acompanhei, no início dos anos 1980, uma disciplina ministrada na Escola de Comunicação e Artes (ECA) pelo professor Egon Schaden, que havia se aposentado na Faculdade de Filosofia, Letras e Ciências Humanas (FFLCH).

Apesar de não ter tido muitas aulas sobre o tema, estava à procura de oportunidades para trabalhar com povos indígenas. Em uma ocasião, fui assistir a uma apresentação do Projeto Kaiowá Ñandeva (PKÑ), que estava sendo iniciado pelo antropólogo Rubem F. Thomaz de Almeida, com os Guarani e Kaiowá, no Mato Grosso do Sul. Era uma iniciativa indigenista, que fazia parte de um conjunto de projetos de antropólogos ligados às Declarações de Barbados (reproduzidas em Oliveira $G$ Freire, 2006). O PKÑ tinha relação com o Projeto Paĩ-Tavyterã (PPT), implementado na província de Amambay, no Paraguai, região da fronteira com Brasil.

A partir desse contato, em 1978, fui trabalhar com os Guarani no PKÑ no município de Amambai (MS), na aldeia de Takauapiry (posteriormente grafada Taquaperi). Naquela época, havia um grupo de pesquisadores que atuava em uma antropologia engajada, preocupada em produzir do ponto de vista acadêmico, mas também em demarcar terras, em pensar políticas públicas de educação e saúde junto com os povos indígenas.

Os Guarani me pediram para ajudar na escola, porque eles estavam sendo alfabetizados apenas em português, uma língua que as crianças não entendiam. 
Os adultos queriam que as crianças estudassem para melhor lidar com os karaí, os não indígenas, e para isso a alfabetização deveria ser feita na língua que elas falavam, ou seja, em guarani. É importante lembrar que, durante os anos 1970, principalmente após 1978, data da divisão do Mato Grosso e criação do Mato Grosso do Sul, os Guarani estavam sofrendo despejos das fazendas, em virtude do novo impulso do desenvolvimento agrário na região, focado principalmente no plantio de soja e na criação de gado, com a abertura de fazendas e desmatamento em larga escala. A Funai conversava com as famílias Guarani e as transferia, mesmo forçadamente, para uma das oito antigas reservas demarcadas no período do Rondon, entre 1910 e 1930, como a de Takauapiry, onde eu trabalhava. Presenciei várias dessas chegadas de famílias inteiras trazidas pela Funai para essa aldeia.

Nesse cenário, e com a indicação de que trabalharia com a escola, em 1979 decidi fazer um censo da aldeia, guiando-me por obras como o Guia Prático de Antropologia (Criagbi, 1973) e a Introdución a la Etnografia (Mauss, 1974), ambas indicações de Aracy. O Guia é um manual, preparado por uma comissão do Real Instituto de Antropologia da Grã-Bretanha e Irlanda, que tem por finalidade orientar o antropólogo sobre as etapas da pesquisa de campo a serem seguidas. Há uma seção da publicação que apresenta indicações de como se deve fazer um censo demográfico, contar o número de casas e de famílias, descrever a forma como as famílias se organizam, elaborar desenhos e esquemas e assim por diante. Detalha também a técnica de anotar dados acerca do sistema de parentesco e informa, por exemplo, que cada povo tem classes de idade. No livro de Mauss, também há essa indicação sobre a utilização de uma contagem populacional para conhecer a unidade básica social com a qual se trabalha. Então, em julho de 1979, fiz uma ficha para cada família e visitei todas as casas da aldeia/reserva, registrando inclusive o processo de deslocamento forçado pelo qual a população estava passando. Cheguei a um resultado de contagem populacional total na reserva de 814 pessoas.

Recordo-me que a Funai tinha um livro de registro de nascimentos, que constituía a fonte principal acerca dos nascimentos nas comunidades, assim como um livro de casamentos e de óbitos. Os dados eram preenchidos na medida em que os indígenas chegavam ao Posto Indígena (PI), que ficava distante para a maioria das famílias. Por isso, as informações eram muitas vezes inexatas, embora alguns funcionários, sobretudo os chefes de posto, fizessem um esforço para manter uma contagem populacional e o registro de casamentos atualizados. Os dados produzidos localmente eram enviados, por meio de relatórios periódicos, para as delegacias da Funai e, posteriormente, seguiam para Brasília, sede do órgão indigenista, que nessa época estava vinculado ao Ministério do Interior. Com base nessas informações, calculava-se o orçamento que seria disponibilizado no ano seguinte para ações de desenvolvimento e apoio às populações indígenas. 
Figura 1 - Marta Maria do Amaral Azevedo com sua filha ao colo, em aldeia Guarani Kaiowá (MS), em 1982

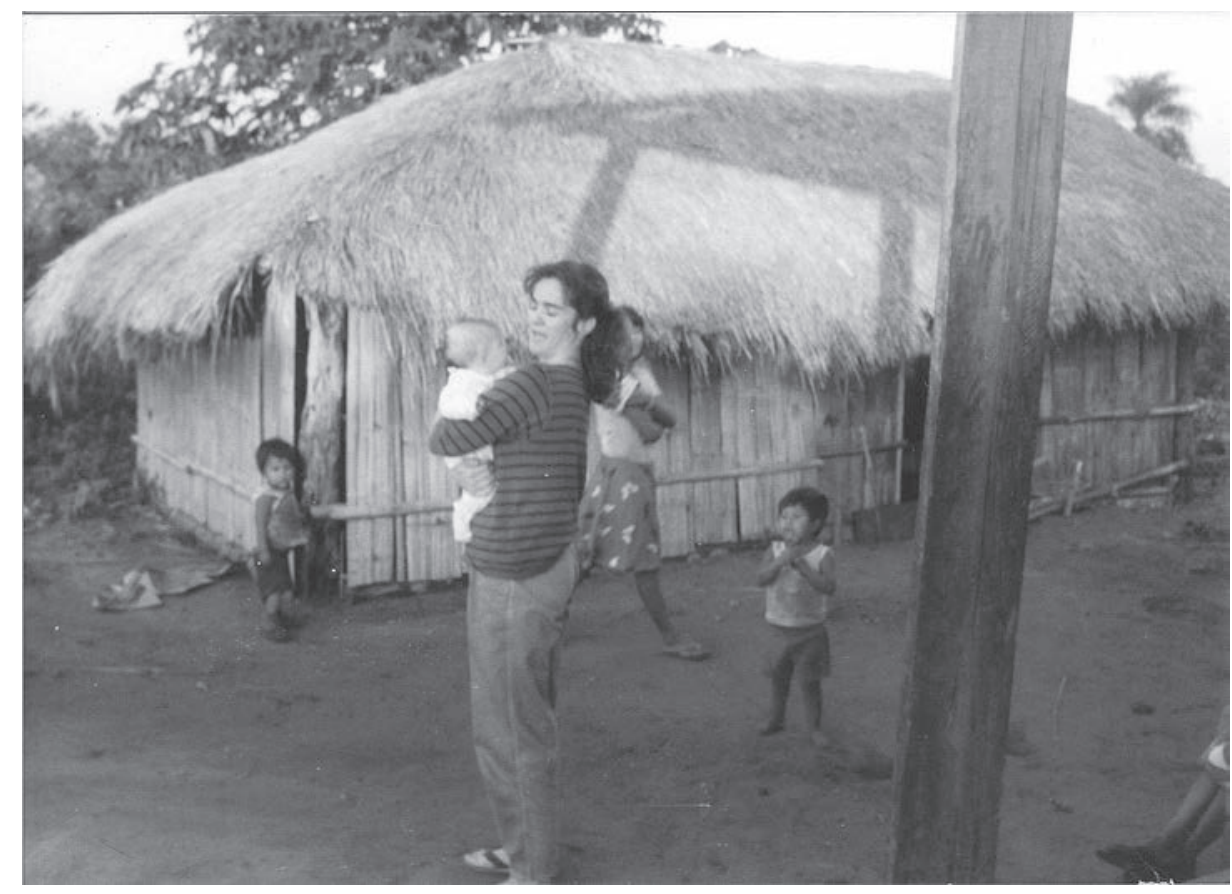

Arquivo pessoal Marta Azevedo.

É curioso que, com esse censo, produzi informações sobre a população Guarani da aldeia de Taquaperi de que o próprio órgão indigenista não dispunha. Enquanto lá residia, recordo-me que a Operação Anchieta, atual Operação Amazônia Nativa (Opan), e o Cimi, foram até a aldeia em que eu estava como parte do projeto de levantamento da população indígena em todo o país, publicado no jornal Porantim (Cimi, 1982). Foi uma iniciativa para conhecer efetivamente o contingente populacional e a situação de vida dos povos indígenas nessa época. Isso porque durante a ditadura militar foram feitas tentativas de emancipação dos povos indígenas, o que significava que o governo deixaria de reconhecer ou considerar pessoas como indígenas. Ou seja, nas décadas de 1970 e 1980, o recenseamento não era apenas uma atividade de pesquisa, mas também um ato político, pelo reconhecimento da existência de povos indígenas no Brasil.

Antes de me interessar propriamente por questões demográficas, participei também do levantamento sobre a população indígena no Brasil feito pelo Cedi, coordenado pelo antropólogo Carlos Alberto Ricardo. A partir de 1980, foi estruturada uma ampla rede de colaboradores voluntários para o projeto Povos Indígenas no Brasil, que contava com a participação de pesquisadores, antropólogos, indigenistas, missionários e indígenas. A ideia era "colocar os índios no mapa do Brasil" (frase 
dita por próprio Beto Ricardo), mostrando a importância e a expressão dos povos indígenas no território nacional. O projeto possibilitou a publicação de volumes retratando a presença indígena no país e dando visibilidade a essa população.

Essas foram as minhas primeiras aproximações com a demografia, que tiveram um papel importante para o campo indigenista e político de desmistificar a ideia vigente, no início dos anos 1970, de que os indígenas deixariam de existir no Brasil. As iniciativas de levantamento populacional apontaram, ao contrário, um processo de crescimento da população indígena e sua presença em quase todo o território nacional. Certamente foram muito importantes para o processo do reconhecimento dos direitos indígenas na Constituição de 1988.

Esse movimento estava relacionado com as duas sessões realizadas sobre demografia e povos indígenas que ocorreram nos encontros da Abep de 1982 e 1984?

Certamente. Uma rede de indigenistas e antropólogos foi se formando nos anos 1970. Acho que é possível identificá-los como engajados com uma certa "antropologia aplicada", como escreveu Roger Bastide, conectados às Declarações de Barbados, mencionadas anteriormente, das quais muitos participaram ativamente, como o dr. Georg Grünberg. Não estive pessoalmente nos encontros da Abep dos anos 1980, mas Lux Vidal e Carmen Junqueira, antropólogas importantes para esse movimento, estiveram nas reuniões, o que mostra uma primeira aproximação formal entre antropólogos e demógrafos preocupados com os povos indígenas no Brasil. Posteriormente, nesta entrevista, podemos resgatar essa história nos encontros do GT Demografia dos Povos Indígenas da Abep, ${ }^{3}$ mas, ao longo dos anos 1980, eu acompanhava e atuava, sobretudo, com a questão da educação escolar indígena.

Foi com esse tema da educação que você foi convidada para ir para o Alto Rio Negro, Amazonas, pela primeira vez?

Justamente. Em 1979 eu já estava envolvida com educação escolar indígena, e promovemos um encontro que resultou no livro A Questão da Educação Indígena, organizado por Aracy Lopes da Silva (Lopes da Silva, 1981). Em 1989 fundamos o Mari - Grupo de Educação Indígena -, no departamento de antropologia da USP. Derivava de um grupo que tinha se formado anteriormente no âmbito da Comissão Pró-Índio de São Paulo, como uma espécie de departamento da comissão. O Mari tinha como objetivo promover, assessorar e publicar reflexões e debates em torno da educação indígena, tanto para indígenas quando para não indígenas, divulgando materiais e livros sobre os povos indígenas para o grande público. No mesmo ano, fui convidada pela professora Rosa Helena Dias da Silva (Rosinha) a participar do Encontro dos Professores Indígenas do Amazonas e Roraima, mas só 
pude ir ao encontro de 1990, quando conheci Gersem dos Santos Luciano Baniwa, que estava na delegação dos professores do Alto Rio Negro, Amazonas. Em julho de 1991, Gersem me convidou a ir para o Rio Negro, juntamente com Rosinha, para darmos um curso de administração geral para as organizações indígenas, o primeiro curso de administração geral da Federação das Organizações Indígenas do Rio Negro (FOIRN). As comunidades indígenas do Alto Rio Negro já há algum tempo se organizavam em diversas associações e, em 1990, a FOIRN contava com mais de 60 organizações filiadas na época. As lideranças, cerca de 50, estavam interessadas em aprender a redigir projetos, relatórios, cartas, documentos e a fazer prestação de contas, para poderem operar e melhorar as iniciativas das próprias associações e da FOIRN.

Aceitei o convite e em janeiro de 1992 fiz a primeira viagem para o Rio Negro. Rosinha e eu passamos o mês de janeiro em São Gabriel da Cachoeira trabalhando com as lideranças. Nossa abordagem sempre foi a de propor atividades práticas durante os cursos de formação, permitindo o desenvolvimento de projetos que fizessem sentido para as realidades e interesses locais. O exercício escolhido pelas lideranças das associações e da FOIRN foi a elaboração de um projeto para a realizar um censo das comunidades e famílias da região do Rio Negro.

Nessa época, os indígenas estavam lutando pela demarcação de suas terras, e havia um processo jurídico do Ministério Público Federal contra a demarcação do território em ilhas descontínuas, que havia sido feita pelo governo José Sarney. Além disso, o Censo Demográfico de 1991, realizado pelo Instituto Brasileiro de Geografia e Estatística (IBGE), tinha acabado de passar na região para a coleta de dados. A informação populacional era, e é, essencial para o processo de demarcação de terras.

Os dados sobre a população variavam de 3 mil (segundo o governo estadual do Amazonas) a 30 mil pessoas (segundo o Cimi). A Funai estimava cerca de 10 mil na região do Alto Rio Negro. Ou seja, não se sabia ao certo qual era o número de indígenas residentes no Alto Rio Negro.

As lideranças indígenas, portanto, queriam saber e entender o que era um censo. Para isso, nos pediram para elaborar um projeto para realização de um censo demográfico na região, que foi o trabalho final do curso de administração geral que estávamos realizando (Azevedo, 1992).

Quando voltei para São Paulo, em março de 1992, fui ao Nepo/Unicamp na companhia de Márcio Silva, colega que também assessorava o Movimento dos Professores Indígenas do Amazonas, Roraima e Acre. Fomos recebidos pelas professoras Maria Coleta de Oliveira e Suzana Cavenaghi, que nos explicaram um pouco mais sobre a realização de um censo autônomo. Também nos indicaram alguns livros sobre o tema e deram sugestões importantes para o questionário, que estava em fase inicial de formulação. Depois, conversei também com Aracy, que na ocasião estava vinculada à Universidade Federal de São Carlos (UFSCar), e ela também me 
incentivou, dizendo que havia realmente dificuldades no diálogo entre antropólogos e demógrafos. Embora os manuais de antropologia que usávamos apontassem para a importância de realização de censos nas aldeias, esses eram considerados, sobretudo, como ferramentas para a investigação de temas como parentesco, por exemplo. Em geral, nos estudos antropológicos, não havia uma interpretação desses dados para entender propriamente a dinâmica populacional, e os resultados das contagens e censos eram publicados, muitas vezes, em notas de rodapé ou anexos das monografias e teses.

Figura 2 - Marta Azevedo (à direita) na aldeia de Iauretê, no Alto Rio Negro (AM), no início da década de 1990

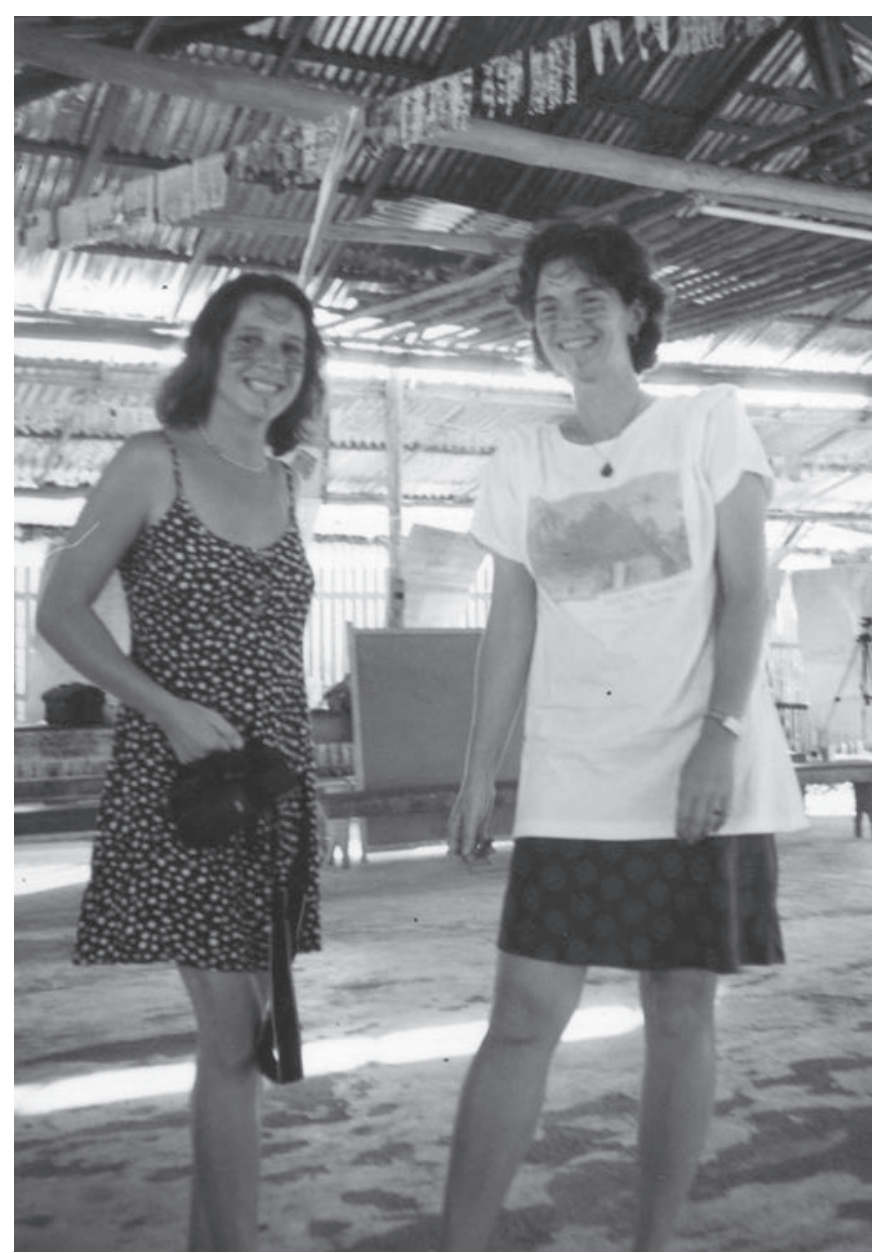

A antropóloga participa de uma atividade com Simone Argentino, enfermeira da ONG Saúde Sem Limites, como parte do projeto Saúde Reprodutiva das Mulheres Indígenas no Alto Rio Negro.

Arquivo pessoal Marta Azevedo. 
Com base nos projetos elaborados para o final do curso com as lideranças indígenas ligadas à FOIRN, a proposta de realização do Censo Indígena Autônomo do Rio Negro (CIARN) foi submetida à Organização Holandesa de Cofinanciamento e Desenvolvimento de Programas (Cebemo) e recebeu financiamento da instituição. O principal objetivo era realizar uma contagem de todas as pessoas e famílias que residiam no território reconhecido pelas lideranças como sendo de ocupação tradicional dos povos indígenas do Alto Rio Negro. O CIARN foi conduzido em conjunto com as lideranças e professores indígenas (estes últimos atuando como recenseadores), e envolveu a aplicação de dois questionários: um por aldeia (também denominada de comunidade ou sítio) e um por domicílio. Em julho de 1992, fomos para campo e, em dezembro, a investigação foi concluída, contabilizando 361 comunidades e uma população de 16.897 pessoas (Azevedo, 2003).

Demoramos um ano para completar a digitação e montar o banco de dados. Para essa etapa foram contratados, por intermédio de uma empresa, quatro digitadores, que alimentaram as informações utilizando um programa em linguagem dBASE.

Em 1994, a FOIRN conseguiu recursos e adquiriu um computador para instalar o banco de dados, que seria a primeira máquina desse tipo a chegar a São Gabriel da Cachoeira. Foi acordado com a FOIRN que esse banco de dados seria de propriedade da instituição, com o propósito de constituir uma ferramenta de trabalho para todos os seus projetos. O programa disponibilizava diferentes sinopses da pesquisa, com informações por calha de rio, por etnia, por idade e sexo, e várias outras, como, por exemplo, sobre a quantidade e o perfil de eleitores. Com as informações do CIARN, os indígenas puderam ter um retrato completo da região do Alto Rio Negro, com subsídios para apresentar e discutir reivindicações nos processos de demarcação das cinco terras indígenas (TIs) contíguas do Alto Rio Negro (Alto Rio Negro, Médio Rio Negro I, Médio Rio Negro II, Apapóris e Tea, cuja homologação aconteceu em 1997. Portanto, a utilização dos dados do CIARN foi imediata, ajudando também a traçar os perfis de migração das aldeias para a cidade de São Gabriel da Cachoeira.

De modo a dar sequência aos trabalhos de análise dos dados, a diretoria da FOIRN, na época, solicitou minha assessoria, convite que aceitei em virtude do interesse em estudar e me aprofundar em demografia. Elaboramos, então, um termo de compromisso por escrito, atestando que todas as informações eram de propriedade dos povos indígenas e que a divulgação das mesmas só poderia ocorrer com anuência da FOIRN. Ficou acordado também que eu poderia analisar o banco de dados como parte de minhas atividades de pesquisa. Lembro-me que, na ocasião, fui ao Nepo e conversei com Maria Coleta de Oliveira e Elza Berquó para saber se era possível participar da seleção para o doutorado. Elas foram receptivas e lembraram-se das 
sessões de demografia indígena nos encontros da Abep no início dos anos 1980, que não aconteceram em encontros posteriores, pois não havia demógrafos trabalhando nessa temática. Assim, em 1995, entrei no doutorado na Unicamp. Ao me aproximar da demografia dos povos indígenas, percebi que essa área de pesquisa era muito pouco desenvolvida no Brasil e na América Latina em geral.

Como se deram essa passagem da antropologia para a demografia e a construção do diálogo entre as duas disciplinas? Como foi trabalhar com a produção de um conhecimento na área de demografia antropológica?

É interessante porque há uma desconfiança dos dois lados. A conversa entre as duas disciplinas é difícil, uma vez que há um campo da ciência demográfica que parte do princípio que os dados bons são dados coletados por quem tem distanciamento com relação à pesquisa. Os dados do CIARN foram coletados pelos indígenas, então havia sempre uma dúvida, por parte dos demógrafos, em reação à qualidade deles, principalmente porque a análise mostrava perfis demográficos muito distintos da população residente no Brasil em geral, diferente do que era esperado. No entanto, não se tratava de um problema com a metodologia ou rigor da pesquisa. A explicação para o fato decorria da dinâmica demográfica dos povos indígenas e da influência que variáveis culturais têm sobre fenômenos demográficos. Além disso, havia o desafio metodológico de trabalhar com populações de pequeno porte, e sobre as quais não havia informações prévias aos primeiros levantamentos feitos.

Da mesma forma, os antropólogos acham que somente quem faz etnografia boa é antropólogo, mas não há nessa disciplina treinamento para analisar os censos populacionais derivados das pesquisas de campo. Também havia, e em certa medida ainda há, um desconhecimento do potencial que uma análise demográfica pode trazer para questões antropológicas, o que vai além das pirâmides etárias que muitos antropólogos incluem como anexos de seus trabalhos.

Apesar dessa desconfiança mútua, o diálogo entre as duas disciplinas pode produzir uma boa demografia dos povos indígenas e ajudar a compreender questões etnológicas. Um exemplo foi o projeto Culture and Human Fertility. Esse estudo foi realizado pela International Union for the Scientific Study of Population (IUSSP) na década de 1950, em cooperação com a Unesco, e tinha o objetivo de investigar as condições sociais e culturais que afetavam a fecundidade em países não industriais. A pesquisa foi feita de maneira interdisciplinar e envolveu demógrafos e antropólogos de renome na época, como Frank Lorimer, Giorgio Mortara e Meyer Fortes. A obra resultante apresentou diversos estudos de caso, mostrando a relação entre, por exemplo, o sistema de parentesco de uma população, a fecundidade e o perfil demográfico (Lorimer, 1954). No Brasil, houve um esforço paralelo, quando, nos 
encontros da Abep de 1982 e 1984, foram produzidos artigos e um relatório que traçavam essas relações entre antropologia e demografia (Wong, 1984; Pagliaro, Azevedo G Santos, 2005).

Durante o doutorado, pude entender melhor essa relação interdisciplinar, as potencialidades e desafios na construção de uma demografia antropológica, ao mesmo tempo que aumentava a produção de estudos nesse campo. No início dos anos 1990, e, especificamente com a Conferência das Nações Unidas sobre o Meio Ambiente e o Desenvolvimento, realizada no Rio de Janeiro em 1992 (Eco-92), foi implementado o processo de criação de políticas públicas baseadas nos direitos dos povos indígenas reconhecidos pela Constituição de 1988. As demarcações das terras indígenas deveriam, a partir daquele momento, conter em seus limites os recursos ambientais necessários para o bem-estar e para a reprodução física e cultural de cada povo. Passou, então, a ser necessário conhecer melhor a dinâmica demográfica dessas populações, porque a maioria delas estava passando por um processo de crescimento, e as TIs que estavam sendo demarcadas teriam de sustentar aqueles níveis de crescimento. Ou seja, seria preciso pensar qual seria o território necessário que, além da ocupação tradicional, sustentaria o ritmo do aumento de cada população, considerando a tecnologia e os recursos naturais existentes em cada região. Em 1996, o Governo Federal publicou o decreto n. 1.775, que detalha as diretrizes para a realização dos estudos de demarcação. Logo a seguir, a Funai publicou a portaria do Ministério da Justiça n. 14/1996, que estabelece a estrutura dos relatórios circunstanciados de identificação e delimitação das TIs, que passaram a requerer uma análise demográfica da população.

Na época do doutorado, solicitei a alguns antropólogos e indigenistas, amigos e conhecidos, que me enviassem dados demográficos das populações indígenas com quem trabalhavam para que pudesse fazer os exercícios das disciplinas do curso, além de apoiar as demandas dos antropólogos e seus estudos. Nesse período, fiz análises sobre os Wajãpi, com dados coletados pela professora Dominique Gallois e sua equipe, e sobre os Enawenê-Nawê, com dados cedidos pela Opan e pelo professor Márcio Silva (Azevedo, 2000).

Interessante notar que, nessa época, estavam sendo publicados importantes estudos em antropologia demográfica, como o volume The Demography of Small-Scale Societies: case studies from lowland South America, organizado por Kathleen Adams e David Price, que reuniu trabalhos apresentados ao longo de anos na South American Indian Conference, realizada no Bennington College, nos Estados Unidos (Adams G Price, 1994). No caso dessa publicação, os estudos de caso apresentados são, em sua maioria, sobre povos indígenas no Brasil.

Além disso, o Censo de 1991 do IBGE foi o primeiro a incluir a categoria "indígena" na pergunta sobre "cor ou raça". Em novembro de 1996, participei do Seminário Populações Amazônicas: tendências recentes e perspectivas, organizado 
pelo dr. Hélio Moura, na Fundação Joaquim Nabuco (Fundaj), em Manaus. Meu trabalho era o único que apresentava uma discussão sobre povos indígenas. Utilizei os dados do Censo de 1991 e mostrei que os dados da população indígena em Manaus estavam subestimados se comparados com outras fontes de informações (Azevedo, 1997; Heck, 1996; 1997). Mesmo que os dados apresentassem um problema de cobertura da pesquisa, ou de metodologia, ressaltei, no estudo, que a existência de informações demográficas já era um importante avanço.

Ou seja, durante os anos 1990, houve um avanço na política indigenista, o que levou a um interesse sobre as estatísticas oficiais da população indígena no país. Esses materiais, e também os debates, da década de 1990 geraram um novo ciclo de interesse e pesquisas. Parte dessa reflexão está em um artigo que publiquei no livro Povos Indígenas no Brasil 1996/2000, editado pelo Instituto Socioambiental (Azevedo, 2000).

Esse novo ciclo de pesquisas sobre demografia dos povos indígenas está relacionado com a formação do GT Demografia dos Povos Indígenas da Abep?

Sem dúvida. Interessados no tema, eu e um conjunto de colegas começamos a interagir e a pensar sobre essa produção contemporânea de demografia antropológica na segunda metade dos anos 1990 e no início dos anos 2000. Cada um de nós, incluindo Heloisa Pagliaro, Ricardo Ventura Santos, Nilza de Oliveira Martins Pereira, Pery Teixeira, estávamos trabalhando, ou passamos a trabalhar, com temas relacionados à demografia indígena, dedicados a pesquisas locais, utilizando dados coletados por meio de surveys ou censos autônomos, ou com longas séries históricas. Eu estava trabalhando com o CIARN; Heloísa desenvolvia trabalhos com base em dados produzidos, desde a década de 1960, pelo Programa Xingu da Universidade Federal de São Paulo (Unifesp) sobre os povos indígenas do Parque do Xingu; Ricardo Ventura Santos, Carlos E. A. Coimbra Jr. e Nancy Flowers estavam envolvidos em estudos na interface entre antropologia, demografia e saúde sobre os Xavante. Somente Nilza Pereira não trabalhava com dados primários. Ela atuava no IBGE e utilizava os dados dos Censos de 1991 e 2000, gerando as primeiras análises com base nessas fontes de informação de escala nacional.

Mas antes de falar sobre o GT em si, acho importante destacar o papel que Heloisa Pagliaro teve na iniciativa de organizarmos um grupo e também no desenvolvimento do processo, mantendo uma continuidade nos encontros e na agenda de nossas pesquisas. Heloísa, falecida em 2012, foi socióloga e antropóloga, fez mestrado em demografia na Universidade Paris 1, nos anos 1970, e doutorado na USP, no período de 1998 a 2002. ${ }^{4}$ Sua primeira aproximação com a demografia das populações indígenas ocorreu enquanto atuava na Escola Paulista de Medicina/ Unifesp, sede do Projeto Xingu. Motivada por uma solicitação do professor Roberto 
Baruzzi, coordenador do projeto, Heloísa começou a trabalhar com os dados de vários povos do Parque Indígena do Xingu.

Em 1994, foi coautora de um artigo, com Baruzzi, analisando o comportamento demográfico do povo Panará, apresentado em um encontro da Abep (Baruzzi et al., 1994). Heloísa desenvolveu uma análise da dinâmica demográfica do povo Kaiabi no período de 1970 a 1999 com vistas a seu doutorado (Pagliaro, 2002). Seu trabalho mostrou que essa população indígena passava por um crescimento populacional com taxas muito altas, o que ela denominou de "revolução demográfica". Nessa época, a demonstração estatística de que a população indígena estaria aumentando em ritmo acelerado era ainda muito assustadora para a comunidade dos demógrafos e para os acadêmicos em geral no Brasil. Isso a ponto de, durante a qualificação de doutorado, ter sido requisitado a Heloisa que fizesse um teste de veracidade dos dados coletados pela equipe médica da Unifesp para verificar se sua análise estava correta. Ela fez, então, um pedido para que o demógrafo Paulo Campanário, especialista em teste e simulação populacional (campo que estava começando a ser desenvolvido), testasse seus dados. O trabalho demonstrou que a população efetivamente apresentava níveis de fecundidade altos e que o crescimento populacional dos Kaiabi era alto, e provavelmente continuaria alto nos anos futuros (Campanário, 2005).

Conheci Heloísa enquanto estávamos fazendo doutorado. Ela me procurou porque eu tinha uma cópia da publicação mencionada anteriormente, qual seja, Demography of Small-Scale Societies: case studies from lowland South America. A partir de então, começamos essa articulação no campo da demografia, que culminou na criação do GT. Heloisa conhecia o professor Pery Teixeira, pois os dois haviam estudado juntos na França. Quando Pery assumiu o escritório da Fundaj em Manaus, ela o incentivou a trabalhar com informações sobre as populações indígenas. Ricardo Ventura Santos já trabalhava com povos indígenas e tinha conhecimento tanto de demografia quanto antropologia, especialmente no campo da saúde. O envolvimento de Ricardo também ajudou a estabelecer pontes entre colegas que atuavam na Abep e pesquisadores da área da saúde vinculados à Associação Brasileira de Saúde Coletiva (Abrasco).

Nilza Pereira expôs seu primeiro trabalho sobre a população indígena no encontro da IUSSP de 2001, desenvolvendo uma análise baseada nos resultados do Censo de 1991, comparando-os com os dados de 2000, algo muito mais detalhado do que havia sido publicado pelo IBGE até então (Pereira et al., 2001). Nessa época, ainda era raro cartografar as informações demográficas, e, em outra ocasião, ela apresentou dados dos povos indígenas do Alto Rio Negro e dos Yanomami em um seminário do GT da Abep. Nós pudemos ver, então, como os dados poderiam estar subestimados e como era importante estabelecer uma parceria com o IBGE, porque o instituto estava utilizando conceitos desatualizados em relação à Constituição de 1988, o que fez, por exemplo, com que os recenseadores em 1991 fossem apenas 
a "postos indígenas, missões e aldeamentos missionários", conforme descrito no manual do Censo. Apesar desses problemas, a produção dos dados referentes a 1991 foi extremamente importante para os antropólogos, uma vez que foi possível dar uma visão geral da situação da população de todos os povos indígenas no país. Pudemos refletir também sobre o fato de que a maioria de nós trabalhava com outras fontes de informação que não as oficiais e de que havia um interesse por parte do IBGE em aprimorar as análises sobre a população indígena no Brasil.

É importante lembrar que vários colegas da área da antropologia apoiaram esse movimento, como Carmen Junqueira, Mariza Corrêa e João Pacheco de Oliveira, identificando a importância política da existência (e disponibilização) de fontes de informação oficiais sobre os povos indígenas no Brasil. Em 1997, Mariza Corrêa, então presidente da Associação Brasileira de Antropologia (ABA), por indicação do professor Marcio Silva, me solicitou que fosse a representante da associação no Comitê Consultivo da Sociedade Civil para o Censo de 2000. Para cada reunião, produzia um relatório que, eventualmente, era publicado no boletim da ABA. Assim, o tema da demografia dos povos indígenas despertou um certo interesse na comunidade antropológica e começamos a ter mesas-redondas sobre demografia em antropologia, saúde e educação nas reuniões da ABA, que acontecem a cada dois anos. Estávamos envolvidos em um amplo movimento pela produção de estatísticas oficiais dos povos indígenas, seja através de recenseamentos ou de estatísticas vitais. Logo depois, em 1999, o Instituto Nacional de Estudos e Pesquisas Educacionais Anísio Teixeira (Inep) realizou o primeiro censo escolar indígena.

Como essa rede de pesquisadores se articulou para a constituição do GT Demografia dos Povos Indígenas no Brasil na Abep?

No início o GT foi constituído como um comitê. Em 2001, na XXIV Conferência da IUSSP em Salvador, Heloísa e eu fomos conversar com o então presidente da Abep, Eduardo Rios-Neto, do Cedeplar, sobre a possibilidade de criação de um GT de demografia dos povos indígenas. Não tínhamos muita esperança, porque a área era vista como algo muito estranho, tanto na demografia como na antropologia, o que era agravado pela invisibilidade estatística desses povos. Felizmente, Rios-Neto foi extremamente receptivo à ideia, e nós também tínhamos apoio de muitos outros colegas, como Elza Berquó, Maria Coleta, Suzana Cavenaghi, Ricardo Ventura Santos, José Alberto Magno de Carvalho, Laura Wong. Vários desses pesquisadores já participavam de discussões sobre demografia dos povos indígenas nos encontros da Abep anteriores a 2001, de modo que viam com bons olhos a criação do comitê.

Assim, em março de 2002, foi criado o Comitê de Demografia dos Povos Indígenas pela diretoria da Abep. A primeira tarefa do grupo foi divulgar a questão 
da falta de informações e estatísticas oficiais sobre os povos indígenas, com base na nossa produção dos anos 1990. Também nos incumbimos de entender de que forma seria possível melhorar a captação de informações sobre esses povos por meio dos sistemas oficiais. Montamos uma rede de pesquisadores ligados a diversas instituições parceiras, como o Programa Xingu da Unifesp, o Cedeplar, o Nepo, a Fundação Oswaldo Cruz (Fiocruz), a ABA, a Abrasco e o IBGE, órgão que passou crescentemente a participar de seminários e debates.

Figura 3 - Participantes do GT Demografia dos Povos Indígenas no XIV Encontro Nacional de Estudos Populacionais, realizado de 20 a 24 de setembro de 2004, em Caxambu (MG)

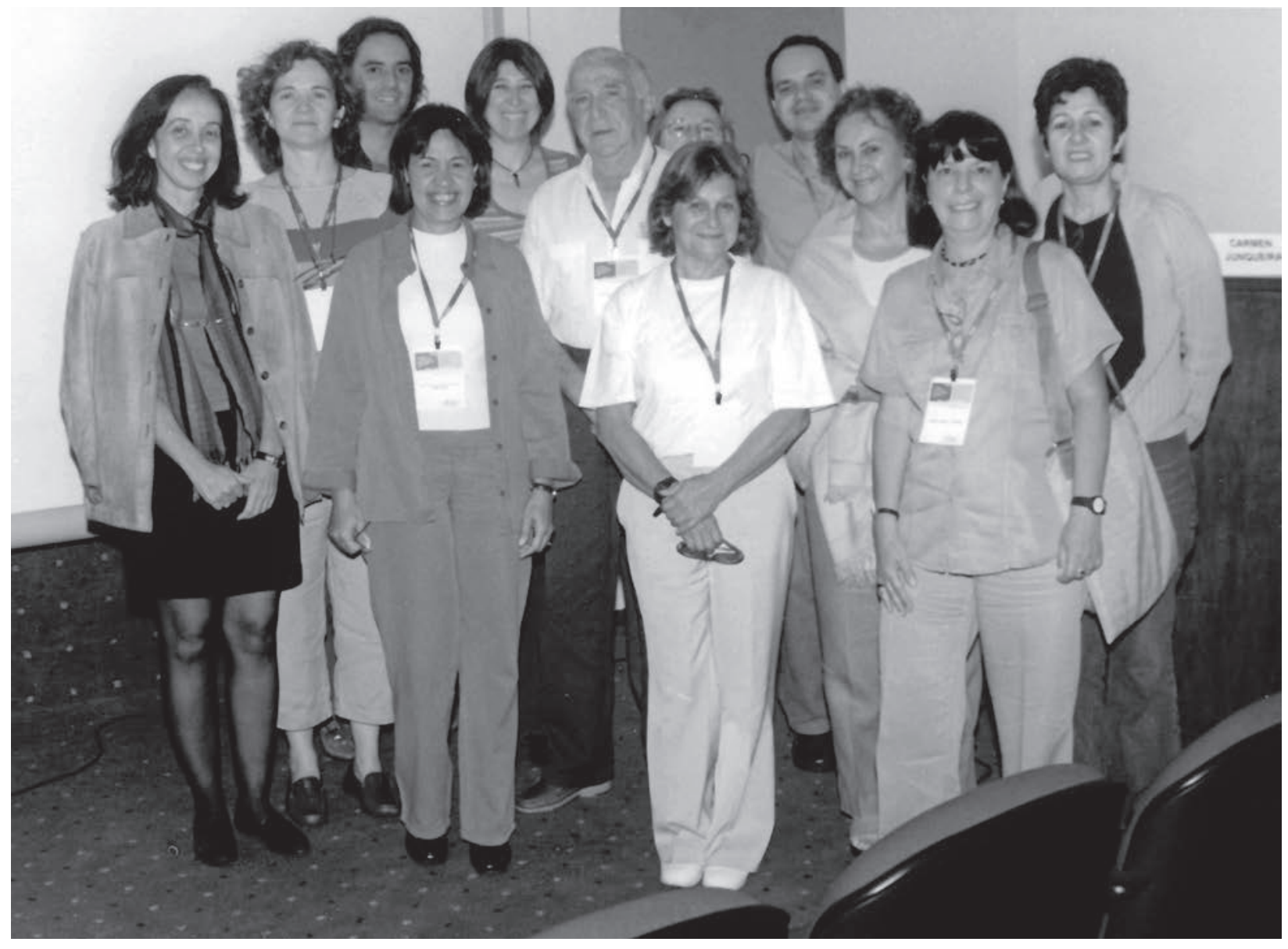

A partir da esquerda: Maria Elizabeth Brea Monteiro (Funai); Marta M. do Amaral Azevedo (Unicamp); aluno de pós-graduação da Unicamp; Nilza de Oliveira M. Pereira (IBGE); Eliana Elizabeth Diehl (UFSC); Roberto Geraldo Baruzzi (Unifesp); Carmen Sylvia de A. Junqueira (PUC/SP); Ana Lucia Escobar (ao fundo, rosto parcialmente visível) (Unir); Ricardo Ventura Santos (Fiocruz e MN-UFRJ); Maria Stella F. Levy (USP); Heloisa Pagliaro (Ufba e Unifesp) e Luciene de Souza Guimarães (Funasa).

Arquivo pessoal Ricardo Ventura Santos. 
O comitê procedeu também a uma revisão do conhecimento acumulado sobre o quantitativo da população indígena no Brasil. Uma das primeiras iniciativas que encontramos foi o censo que Darcy Ribeiro havia realizado em meados do século XX. Em 1956, ele publicou um artigo muito importante no periódico Sociologia, intitulado "Convívio e contaminação: efeitos dissociativos da depopulação provocada por epidemias em grupos tribais" (Ribeiro, 1956) 5 e, no ano seguinte, o texto "Culturas e línguas indígenas no Brasil", que saiu na revista Educação e Ciências Sociais (Ribeiro, 1957). Nesses dois estudos, Ribeiro trata do tema do número de povos indígenas no Brasil, apresenta um levantamento das etnias e grupos tribais, aborda a quantidade de famílias linguísticas e faz uma reflexão sobre o aumento ou queda da população indígena no país.

Demógrafos historiadores já haviam produzido livros e artigos sobre as epidemias e seu efeito em termos de depopulação entre os povos indígenas nas Américas, mas Ribeiro buscava sistematizar uma reflexão que associava demografia, antropologia e sociologia. Em 1970, ele retoma esses interesses e publica dois livros com capítulos sobre questões demográficas, quais sejam, O Processo Civilizatório e Os Índios e a Civilização (Ribeiro, 1968, 1977). Nesses trabalhos, buscou relacionar as transformações pelas quais as comunidades indígenas passavam, em decorrência do contato com não indígenas, e os processos de crescimento e de perdas populacionais já identificados em alguns grupos. Alguns anos depois, também no âmbito da antropologia, a questão demográfica indígena foi abordada em diversos capítulos do volume História dos Índios no Brasil, organizado por Manuela Carneiro da Cunha (1992), assim como em publicações de Mércio Gomes, que, em alguma medida, davam continuidade ao trabalho de Ribeiro (Gomes, 1988).

Como mencionei antes, na primeira metade da década de 1980, especificamente em 1982 e 1984, duas mesas temáticas foram realizadas nos encontros da Abep. Para a discussão de 1982, Lux Vidal, antropóloga da USP, preparou um relatório em que mostrava que diversas comunidades indígenas que haviam sobrevivido ao processo de perdas populacionais decorrente da colonização passavam por "acentuado aumento demográfico" (Vidal, 1982). ${ }^{6}$ A pesquisadora também destaca a falta de estatísticas vitais e recenseamentos da população indígena no Brasil, mas também as iniciativas de contagem desses povos que estavam sendo realizadas pelo Cimi, órgão da Conferência Nacional dos Bispos do Brasil (CNBB), e pelo Cedi - centro do qual fui colaboradora por vários anos.

Com base nessa revisão do conhecimento sobre o tema, realizamos em 2003 o Primeiro Seminário de Demografia dos Povos Indígenas no Brasil, na Unifesp. O evento contou com a participação de pesquisadores estrangeiros, incluindo John Early, antropólogo e demógrafo que havia publicado diversos estudos sobre demografia dos Yanomami, produzidos em colaboração com o missionário John Peters (Early G Peters, 1990; Early, et al., 2005). Nesse seminário, 
apresentamos trabalhos baseados em dados populacionais com que estávamos operando, que mostravam que a população indígena no Brasil estava em acelerado processo de crescimento. Heloísa chamou esse fenômeno de "revolução demográfica", como já mencionado anteriormente. Carlos E. A. Coimbra Jr., Ricardo Ventura Santos, Nancy Flowers e Francisco Salzano também descreveram o processo na obra The Xavante in Transition, livro pioneiro ao propor uma reflexão acerca das maneiras como a trajetória histórica, saúde, ambiente e ecologia humana se relacionavam com o perfil e a dinâmica demográfica de um povo indígena específico, no caso os Xavante da TI Pimentel Barbosa, em Mato Grosso (Coimbra Jr. et al., 2002).

Esse crescimento da população indígena também estava sendo observado nos demais países da América Latina?

Sim. Em 2004 participamos da articulação de uma rede latino-americana no âmbito da Alap. Conforme já mencionei, em 2001, começávamos a estruturar o comitê na Abep, com a organização do seminário, sessões temáticas e mesasredondas nos encontros da Abep, que funcionavam e ainda funcionam como espaços de discussão, nos quais desenvolvemos nossas análises, reflexões e desafios metodológicos e teóricos. A criação da Alap ocorreu concomitantemente com a realização de seu primeiro congresso, em Caxambu, Minas Gerais, do qual participamos com duas sessões temáticas. Diversos antropólogos, como Bartomeu Melià, estavam presentes, o que contribuiu para a criação da Red Dinámica de las Poblaciones y Pueblos Indígenas de América Latina. Estabelecemos uma parceria com o Centro Latino-Americano e Caribenho de Demografia (Celade), que é a divisão de população da Comissão Econômica para a América Latina e o Caribe (Cepal), em que destaco a participação de Fabiana Del Popolo. Em 1994, o Celade já havia realizado uma reunião com especialistas em povos indígenas cujo tema era justamente o conhecimento e a produção de informações demográficas sobre esses povos na América Latina.

Ao longo desses vários encontros, tivemos muitas sessões sobre a dinâmica e comportamento demográfico dos povos indígenas em diversos países da região, além do Brasil. Observavam-se fenômenos muito semelhantes acontecendo com os povos indígenas de países da América Latina e Caribe. A recuperação populacional, com altas taxas de fecundidade, era comum a todos, o que poderia indicar aspectos da primeira fase da transição demográfica ocorrendo entre os povos indígenas, com queda nas taxas de mortalidade infantil (TMIs), ocasionada pela melhoria do atendimento à saúde e disponibilização de vacinas (Azevedo, 2006). No Brasil, apesar de também apresentarem uma tendência de queda, as TMIs ainda eram altas, em comparação com as da população não indígena (mesmo calculando-se por macrorregiões). Havia algumas exceções, como, por exemplo, entre os povos indígenas 
no Parque do Xingu, cujas taxas começaram a diminuir nos anos 1960 e ficaram mais baixas, no final dos anos 1990 e início do século XXI, do que as da população não indígena, o que comprova a importância fundamental do atendimento à saúde dessas comunidades, como o realizado pelo Programa Xingu da Unifesp.

Outras semelhanças foram identificadas quanto à migração de jovens para as áreas urbanas, em análise feita em conjunto com o Celade, com bancos de dados compilados e organizados por essa instituição, e também quanto à saúde reprodutiva e fecundidade. Em relação a essa segunda questão, chamamos atenção para as especificidades no perfil e no comportamento reprodutivo de diferentes povos da América Latina. Em 2008, Laura Wong, então presidente da Alap, organizou uma coletânea intitulada Población y Salud Sexual y Reproductiva en América Latina, na qual reuniu trabalhos que haviam sido apresentados nos encontros da Alap de 2004, 2006 e 2008 (Wong, 2008). Nessa publicação, Heloísa e eu assinamos um texto em que analisamos diferentes comportamentos demográficos, perfis de fecundidade e questões culturais (Pagliaro G Azevedo, 2008). Propusemos uma reflexão sobre temas, como perfis de fecundidade, descendência matrilinear/patrilinear, uroxilocalidade/virilocalidade, padrões de assentamento e ecologia humana, ou seja, tratava-se de uma efetiva tentativa de diálogo entre antropologia e demografia. Em 2009, a Alap promoveu em Lima o Seminário Latino-Americano sobre Demografia, por ocasião dos 15 anos da Conferência Internacional de População e Desenvolvimento de Cairo. Durante esse evento, realizamos uma mesa-redonda sobre Saúde Reprodutiva dos Povos Indígenas da América Latina, inserindo o debate dos direitos específicos dos povos indígenas na pauta dos Objetivos do Milênio construídos pela ONU.

Além dessa articulação na Alap, houve também uma atuação do comitê visando a construir uma agenda internacional no âmbito da IUSSP?

Houve sim. Além da própria criação do comitê na conferência da IUSSP em 2001, coordenamos uma mesa sobre demografia de povos indígenas durante a gestão de José Alberto Magno de Carvalho (1998-2001). A preparação para o congresso da IUSSP, realizado em Tours, na França, em 2005, foi muito produtiva. Isso porque aconteceram discussões muito amplas sobre os conceitos de populações tradicionais, autóctones ou indígenas, incluindo algumas reflexões por parte de povos africanos, asiáticos e indianos. Tive a oportunidade, então, de coordenar o GT e organizar uma sessão temática (Demography of Indigenous Peoples) e uma outra de posters sobre o tema. Tivemos contato com estudiosos do mundo todo e contamos com trabalhos da América Latina, Tailândia, Índia. Houve também um debate sobre as populações consideradas indígenas na África. Massimo Livi Bacci e Joe Potter, dois demógrafos de renome, estavam presentes na sessão temática. 
Em 2006, reencontramos Livi Bacci em um encontro da Abep, em Caxambu, que contou também com a presença do professor Eliel Benites, da etnia Guarani Kaiowá. No evento, tivemos a oportunidade de conversar sobre trabalhos de demografia histórica com foco nos povos indígenas. Livi Bacci tem estudos importantes no campo da macrodemografia e estava realizando uma pesquisa sobre demografia histórica no âmbito das populações indígenas na América Latina, de modo que buscava indicações e referências. Essa pesquisa gerou o livro Conquista: a destruição dos índios americanos (Livi-Bacci, 2007), no qual o demógrafo discute as causas da depopulação, desaparecimento dos povos indígenas durante a colonização nas Américas, e mostra que guerras e escravidão tiveram papel fundamental nesse processo. Ao enfatizar esses fatores, Livi Bacci chamou atenção para outras causas, além das epidemias de doenças infecciosas, que normalmente não são consideradas centrais para a depopulação indígena.

\section{Como foi a continuidade do trabalho do GT na Abep?}

Em 2005, mesmo ano da IUSSP, realizamos dois eventos: o II Seminário de Demografia dos Povos Indígenas no Brasil: quarenta anos do Programa de Saúde da Unifesp/EPM no Parque Indígena do Xingu e o I Seminário Internacional de Demografia e Saúde dos Povos Indígenas na América Latina. Esses dois encontros foram promovidos com a colaboração do nosso GT.

Também, em 2005, foi publicada a coletânea Demografia dos Povos Indígenas no Brasil, em coedição da Editora Fiocruz e Abep. Na introdução desse volume, organizado pela Heloísa Pagliaro, Ricardo Ventura Santos e por mim, apresentamos uma detalhada revisão acerca da produção do conhecimento sobre o tema (Pagliaro, Azevedo G Santos, 2005).

Um dos pontos discutidos no livro foi o de que as categorias utilizadas nos Censos Demográficos de 1991 e 2000 não permitiam cálculos sobre mortalidade e fecundidade por povos ou por TI ou mesmo por município. Ou seja, os dados do IBGE eram limitados para caracterizar populações de pequeno porte. A pergunta sobre "cor ou raça", na qual se insere a categoria "indígena", estava no questionário da amostra, e as informações derivadas de estatísticas vitais, como o Sistema de Informações sobre Mortalidade (SIM) e o Sistema de Informações sobre Nascidos Vivos do (Sinasc), eram limitadas, não apresentavam sequer a distinção urbana/rural. As análises que conseguíamos produzir com rigor científico eram, sobretudo, baseadas em dados obtidos por pesquisadores em contextos locais/regionais específicos.

Ainda em 2005, o IBGE publicou o livro Tendências Demográficas: uma análise dos indígenas com base nos resultados da amostra dos Censos Demográficos 1991 e 2000, sob a coordenação de Nilza de Oliveira Martins Pereira (IBGE, 2005). O GT contribuiu bastante nesse projeto editorial: Pery Teixeira fez a análise de mor- 
talidade infantil, e Laura Wong, a de fecundidade. Diversos outros participantes do GT, entre eles, Heloísa Pagliaro, Ricardo Ventura Santos, Carlos Coimbra Jr, Carmen Junqueira, Maria Elizabeth Brea, Marília Brazil e eu mesma, nos envolvemos nessa publicação. Apesar de ser um grande desafio, defendemos que era essencial incluir a categoria indígena naqueles dois censos, e fizemos algumas recomendações para o aprimoramento metodológico no processo de coleta de dados censitários sobre os povos indígenas.

O terceiro seminário do GT, em 2007, aconteceu no Nepo e teve o objetivo de dar continuidade à discussão acerca da melhoria da captação dos dados sobre indígenas. Uma das questões discutidas foi o aprimoramento da compatibilização entre as malhas cartográficas do IBGE e da Funai. Além da pergunta estar apenas no questionário da amostra, não havia coincidência entre os setores censitários do IBGE e os perímetros das TIs identificadas pela Funai. Essa compatibilização era essencial para que o IBGE pudesse divulgar os dados para cada TI, unidade geográfica segundo a qual a maior parte das políticas públicas para a população indígena são executadas. Para viabilizar o compartilhamento destas informações entre as duas instituições, fizemos uma articulação para que a Funai também participasse do seminário. Com apoio da ABA, conseguimos que o IBGE incluísse no Censo de 2010 o recorte espacial das TIs. Esse foi um dos grandes avanços metodológicos da pesquisa censitária, além da passagem da pergunta "cor ou raça" para o questionário do universo (Azevedo, 2011; Azevedo et al., 2016; Azevedo, 2017; IBGE, 2012; Pereira, 2016; Santos et al., 2019).

O quarto seminário foi realizado em Belo Horizonte, no âmbito das discussões de 15 anos da Conferência de População e Desenvolvimento de Cairo, em agosto de 2009. Na ocasião, foi lançado um dossiê no periódico Caderno $C R H$, intitulado "Povos indígenas no Brasil", que foi a última publicação coordenada por Heloísa Pagliaro (2009).

O quinto seminário ocorreu em conjunto com o II Seminário Internacional de Demografia e Saúde dos Povos Indígenas na América Latina, e foi realizado em Manaus, sob coordenação de Pery Teixeira. Esses eventos tiveram uma grande participação de alunos de graduação e pós-graduação do Norte e Nordeste.

Em 2011 foi realizado o sexto seminário do GT no Instituto de Estudos Socioeconômicos (Inesc), em Brasília. O evento teve a coordenação e a participação de Ricardo Verdum, antropólogo, especialista na temática de políticas públicas e povos indígenas. Discutiram-se temas ligados às interfaces entre políticas públicas, antropologia, legislação indigenista e demografia.

O sétimo seminário, organizado por Ricardo Ventura Santos, ocorreu em 2013 no Museu do Índio, órgão da Funai, no Rio de Janeiro. Foram discutidos no evento os primeiros resultados do Censo Demográfico de 2010. Em 2012, o IBGE havia lançado a publicação Os Indígenas no Censo de 2010: características gerais, 
um marco histórico que, pela primeira vez, deu acesso a informações, para todo o Brasil, de perfil etário, dentro e fora das TIs (IBGE, 2012). Os dados eram riquíssimos e foi uma virada na maneira como o IBGE estava assumindo, analisando e publicando as informações sobre os povos indígenas no país.

A temática do oitavo seminário, realizado em 2015, foi Saúde, Território e Ambiente. Sob coordenação de Ricardo Ventura Santos, o encontro também aconteceu no Rio de Janeiro, em uma das sedes do IBGE. Essa oportunidade foi fundamental, pois tivemos a participação de técnicos, analistas, antropólogos, sociólogos, demógrafos, geógrafos e cartógrafos, tanto do IBGE quanto da Fiocruz, Museu Nacional, Museu do Índio, Universidade do Estado do Rio de Janeiro (Uerj) e demais instituições sediadas na cidade. Naquele momento, já tínhamos uma produção com rigor científico utilizando informações censitárias, em diálogo com a demografia e antropologia que o GT vinha construindo há mais de dez anos. O dossiê publicado na Revista Brasileira de Estudos de População (Rebep), também sob coordenação de Ricardo Ventura Santos, traz trabalhos desenvolvidos com o aprimoramento e sofisticação metodológica possibilitados pelos dados do IBGE, vários dos quais apresentados nos seminários de 2013 e 2015 promovidos pelo GT (Santos, 2016).

Finalmente, em 2017, realizamos o nono seminário em Belo Horizonte, coordenado por Marden Barbosa de Campos e Ricardo Ventura Santos, que teve como um dos principais objetivos iniciar uma discussão sobre as potencialidades do Censo Demográfico de 2020 e a importância da manutenção das questões que permitam a captação da população indígena. Alguns dos trabalhos publicados nesta coletânea são desenvolvimentos de apresentações desse encontro de 2017.

Considerando todo esse percurso dos estudos demográficos sobre os povos indígenas no Brasil, qual seria o balanço da atuação do GT e quais são as perspectivas para o campo?

Acredito que, desde o início da articulação para criação do GT da Abep, conseguimos criar e manter uma rede de pesquisadores e instituições que se estende ao longo de um período de quase vinte anos. Essa é uma grande conquista do grupo como um todo. Pensando em nossos objetivos, é importante destacar que o principal foco foi aprimorar a produção de dados com cobertura nacional e analisá-los com rigor científico. Esse conhecimento deveria abarcar uma reflexão sobre a relação entre cultura e demografia. Ou seja, os estudos demográficos deveriam ser informados pela antropologia e desenvolvidos levando em consideração cada um dos povos e etnias.

Antes de iniciarmos as análises propriamente ditas, tivemos que enfrentar a falta de fontes de informação para esses estudos. A primeira etapa era implementar as fontes, fase em que o censo teve e tem papel central. Esse mesmo esforço 
também foi feito em relação aos dados sobre saúde e educação. Tivemos um grande avanço, mas ainda restam desafios importantes para o funcionamento dos sistemas de estatísticas oficiais sobre os indígenas no Brasil, relacionados à compatibilização e harmonização desses dados. A compatibilização dos perímetros das TIs também é essencial entre as diversas fontes de informações, como o Sistema de Informação da Atenção à Saúde Indígena, o Inep, IBGE e Funai.

Como agenda de pesquisas futuras, destaco a importância da realização de uma demografia histórica dos povos indígenas, com um avanço na investigação comparativa entre dinâmicas e perfis demográficos de povos que têm culturas, estruturas sociais e políticas diferentes. Outros temas importantes, mas que ainda são muito difíceis de pesquisar, em virtude da falta de informações censitárias, são: a mobilidade espacial dos povos indígenas, a migração para as cidades, as mudanças no perfil etário e a queda da fecundidade, o que poderia indicar que os povos indígenas no Brasil estão entrando em uma fase de transição demográfica ou passando por ela. Por fim, é essencial buscar uma maior participação da população indígena na produção de dados e análises demográficas, cenário cada vez mais possível, uma vez que há um crescente número de jovens indígenas ingressando no sistema universitário. Tão estratégico quanto continuar a fomentar a realização de uma demografia indígena é formar demógrafos indígenas no país.

\section{Notas}

1 As entrevistas foram realizadas no âmbito do projeto de pesquisa Saúde dos Povos Indígenas no Brasil: perspectivas históricas, socioculturais e políticas, coordenado por Ricardo Ventura Santos e apoiado pelo Wellcome Trust/UK (financiamento de pesquisa n. 203486/Z/16/Z). Alessandra Traldi Simoni e Bruno Nogueira Guimarães são, respectivamente, bolsistas de doutorado e de pós-doutorado nesse projeto.

2 Marta Azevedo nasceu na cidade de São Paulo/SP, em 22 de abril de 1955.

3 Sobre a gênese do campo da demografia dos povos indígenas na Abep, ver também a Apresentação da presente coletânea.

4 Sobre a trajetória de Heloísa Pagliaro, ver "In memoriam". Disponível em: <www.alapop.org/ alap/SerieInvestigaciones/Serie12/Serie12_Art2.pdf>. Acesso em: 23 abr. 2019.

5 O capítulo de Carolina Arouca Gomes de Brito neste volume aborda, de uma perspectiva sócio-histórica, o trabalho "Convívio e contaminação" de Darcy Ribeiro.

6 A Apresentação da presente coletânea aborda a importância histórica desse texto de Vidal. 
ADAMS, K. G PRICE, D. (Eds.) The Demography of Small-Scale Societies: case studies from lowland South America. Vermont: Bennington College, 1994. (South American Indian Studies, n. 4)

AZEVEDO, M. M. A. Reparando a omissão do IBGE. Porantim, 149: 7, jul./ago. 1992.

AZEVEDO, M. M. A. Fontes de dados para populações indígenas da Amazônia brasileira. Cadernos de Estudos Sociais da Fundação Joaquim Nabuco, 13(1): 163-177, 1997.

AZEVEDO, M. M. A. Censos demográficos e "os índios": dificuldades para reconhecer e contar. In: RICARDO, C. A. (Org.). Povos Indígenas no Brasil 1996/2000. São Paulo: Instituto Socioambiental, 2000 .

AZEVEDO, M. M. A. Demografia dos Povos Indígenas do Alto Rio Negro/Amazonas: um estudo de caso de nupcialidade e reprodução, 2003. Tese de Doutorado, Campinas: Instituto de Filosofia e Ciências Humanas, Universidade Estadual de Campinas.

AZEVEDO, M. M. A. Povos indígenas na América Latina estão em processo de crescimento. In: RICARDO, C. A. G RICARDO, F. (Orgs.). Povos Indígenas do Brasil 2001/2005. São Paulo: Instituto Socioambiental, 2006.

AZEVEDO, M. M. A. O Censo 2010 e os povos indígenas. In: RICARDO, C. A. G RICARDO, F. (Orgs.). Povos Indígenas do Brasil 2006/2010. São Paulo: Instituto Socioambiental, 2011.

AZEVEDO, M. M. A. Os povos indígenas e os censos demográficos no Brasil. In: BERQUÓ, E. (Org.). Demografia na Unicamp: um olhar sobre a produção do Nepo. Campinas: Editora da Unicamp, 2017.

AZEVEDO, M. M. A. et al. O que o Censo de 2010 pode revelar sobre os povos indígenas no Brasil? In: RICARDO, C. A. G RICARDO, F. (Orgs.). Povos Indígenas do Brasil 2011/2016. São Paulo: Instituto Socioambiental, 2016.

BARUZZI, R. et al. Os índios Panará: a busca pela sobrevivência. In: ENCONTRO NACIONAL DE ESTUDOS POPULACIONAIS, IX, 1994, Caxambu. Anais... São Paulo: Abep, 1994.

BASTIDE, R. Antropologia Aplicada. São Paulo: Perspectiva, 1971.

CAMPANARIO, P. Estimativas de fecundidade e de mortalidade de populações de pequena escala através de um modelo demográfico. In: PAGLIARO, H.; AZEVEDO, M. M. A. G SANTOS, R. V. (Orgs.). Demografia dos Povos Indígenas no Brasil. Rio de Janeiro: Editora Fiocruz, 2005.

CARNEIRO DA CUNHA, M. (Org.). História dos Índios no Brasil. São Paulo: Companhia das Letras, 1992.

COIMBRA JR., C. E. A. et al. The Xavante in Transition: health, ecology and bioanthropology in Central Brazil. Ann Arbor: University of Michigan Press, 2002. 
COMISSÃO DO REAL INSTITUTO DE ANTROPOLOGIA DA GRÃ-BRETANHA E DA IRLANDA (CRIAGBI). Guia Prático de Antropologia. São Paulo: Cultrix, 1973.

CONSELHO INDIGENISTA MISSIONÁRIO (CIMI). Estatística: índios que sobrevivem e terras que lhes restam. Quantos são os sobreviventes? Um retrato de nossa população indígena. Porantim, 38: 3-13, abr. 1982.

EARLY, J. D. G PETERS, J. F. The Population Dynamics of the Mucajaí Yanomami. New York: Academic Press, 1990.

EARLY, J. et al. A dinâmica demográfica dos Mucajaí Yanomami: uma entrevista com John Early. In: PAGLIARO, H; AZEVEDO, M. M. G SANTOS, R. V. (Orgs.). Demografia dos Povos Indígenas no Brasil. Rio de Janeiro: Editora Fiocruz, 2005.

GOMES, M. P. Os Índios e o Brasil: ensaio sobre um holocausto e sobre uma nova possibilidade de convivência. Petrópolis: Vozes, 1988.

HECK, E. Índios no IBGE. Porantim, 174: 5, maio 1995.

HECK, E. IBGE e os índios invisíveis. Porantim, 188: 11, set. 1996.

INSTITUTO BRASILEIRO DE GEOGRAFIA E ESTATÍSTICA (IBGE). Tendências Demográficas: uma análise dos indígenas com base nos resultados da amostra dos Censos Demográficos de 1991 e 2000. Rio de Janeiro: IBGE, 2005.

INSTITUTO BRASILEIRO DE GEOGRAFIA E ESTATÍSTICA (IBGE). Censo 2010: características gerais dos indígenas - resultados do universo. Rio de Janeiro: IBGE, 2012.

INSTITUTO NACIONAL DE ESTUDOS E PESQUISAS EDUCACIONAIS (INEP). Censo Escolar Indígena 1999. Brasília: Inep, 2001.

LIVI-BACCI, M. Conquista: a destruição dos índios americanos. Lisboa: Edições 70, 2007.

LOPES DA SILVA, A. (Org.). A Questão da Educação Indígena. São Paulo: Brasiliense, 1981.

LORIMER, F. (Ed.). Culture and Human Fertility: a study of the relation of cultural conditions to fertility in non-industrial and transitional societies. Paris: Unesco, 1954.

MAUSS, M. Introducción a la Etnografia. Madrid: Istmo, 1974.

OLIVEIRA, J. P. G FREIRE, C. A. R. (Orgs.). A Presença Indígena na Formação do Brasil. Brasília: Ministério da Educação, Laced/Museu Nacional, 2006.

PAgliaro, H. A Revolução Demográfica dos Povos Indígenas do Brasil: a experiência dos Kaiabi do Parque Indígena do Xingu - Mato Grosso, 1970-1999, 2002. Tese de Doutorado, São Paulo: Faculdade de Saúde Pública, Universidade de São Paulo.

PAGLIARO, H. Dossiê Povos indígenas do Brasil. Caderno CRH, 22(57): 447-546, 2009.

PAGLiARO, H. G AZEVEDO, M. M. A. Comportamento reprodutivo de povos indígenas no Brasil: interface entre a demografia e a antropologia. In: WONG, L. R. (Ed.). Población y Salud Sexual y Reproductiva en América Latina. Córdoba: Alap, FNUAP, 2008. (Serie Investigaciones) 
PAGLIARO, H.; AZEVEDO, M. M. A. G SANTOS, R. V. (Orgs.). Demografia dos Povos Indígenas no Brasil. Rio de Janeiro: Editora Fiocruz, Abep, 2005.

PEREIRA, N. O. M. Avanços na captação de dados sobre a população indígena no Censo Demográfico 2010. Revista Brasileira de Estudos de População, 33(2): 423-430, 2016.

PEREIRA, N. O. M. et al. The indigenous population of Brazil - 1991 Population Census. In: INTERNATIONAL UNION FOR THE SCIENTIFIC STUDY OF POPULATION GENERAL CONFERENCE, XXIV, 2001, Salvador.

RIBEIRO, D. Convívio e contaminação: efeitos dissociativos da população provocada por epidemias em grupos indígenas. Sociologia, 18: 3-50, 1956.

RIBEIRO, D. Culturas e línguas indígenas do Brasil. Educação e Ciências Sociais, 2: 5-102, 1957.

RIBEIRO, D. O Processo Civilizatório: etapas da evolução sociocultural. Rio de Janeiro: Civilização Brasileira, 1968.

RIBEIRO, D. Os Índios e a Civilização: a integração das populações indígenas no Brasil moderno. Petrópolis: Vozes, 1977.

SANTOS, R. V. Prólogo. Dossiê "Demografia dos povos indígenas no Brasil: abordagens socioantropológicas". Revista Brasileira de Estudos Populacionais, 33(2): 231-235, 2016.

SANTOS, R. V. et al. The identification of the indigenous population in Brazil's official statistics, with an emphasis on demographic censuses. Statistical Journal of the IAOS, 35(1): 26-49, 2019.

SUESS, P. (Org.). Em Defesa dos Povos Indígenas: documentos e legislação. São Paulo: Edições Loyola, 1980.

VIDAL, L. Demografia dos grupos étnicos minoritários: índios. In: ENCONTRO NACIONAL DE ESTUDOS POPULACIONAIS, III, Águas de São Pedro, 1982. Anais... São Paulo: Abep, 1982.

WONG, L. Resumo das discussões sobre o tema "etnia e população". In: ENCONTRO NACIONAL DE ESTUDOS POPUlACIONAIS, IV, Águas de São Pedro, 1984. Anais... São Paulo: Abep, 1984.

WONG, L. R. (Org.). Población y Salud Sexual y Reproductiva en América Latina. Córdoba: Alap, FNUAP, 2008. (Serie Investigaciones) 


\section{Outros títulos da coleção Saúde dos Povos Indígenas}

A Cosmopolítica da Gestação, do Parto e do Pós-Parto: autoatenção e medicalização entre os índios Munduruku

Raquel Paiva Dias-Scopel, 2018

Saúde Indígena em Perspectiva: explorando suas matrizes históricas e ideológicas Carla Costa Teixeira e Luiza Garnelo (orgs.), 2014

Processos de Alcoolização Indígena no Brasil: perspectivas plurais Maximiliano Loiola Ponte de Souza (org.), 2013

Medicinas Indígenas e as Políticas da Tradição: entre discursos oficiais e vozes indígenas

Luciane Ouriques Ferreira, 2013

Transformação e Persistência: antropologia da alimentação e nutrição em uma sociedade indígena amazônica

Maurício Soares Leite, 2007

Demografia dos Povos Indígenas no Brasil

Heloísa Pagliaro, Marta Maria Azevedo e Ricardo Ventura Santos (orgs.), 2005

Poder, Hierarquia e Reciprocidade: saúde e harmonia entre os Baniwa do Alto Rio Negro

Luiza Garnelo, 2003 
Formato: 21 x $26 \mathrm{~cm}$

Tipologia: Egyptian505 BT

Papel: offset $90 \mathrm{~g} / \mathrm{m}^{2}$ (miolo) e Cartão Supremo $250 \mathrm{~g} / \mathrm{m}^{2}$ (capa)

CTP, impressão e acabamento: Imo's Gráfica e Editora Ltda.

Rio de Janeiro, novembro de 2019.

Não encontrando nossos títulos em livrarias,

contactar a EDITORA FIOCRUZ:

Av. Brasil, 4036, térreo, sala 112 - Manguinhos

21040-361 - Rio de Janeiro, RJ

Tel.: (21) 3882-9039 e 3882-9007

Telefax: (21) 3882-9006

editora@fiocruz.br

www.fiocruz.br/editora 